
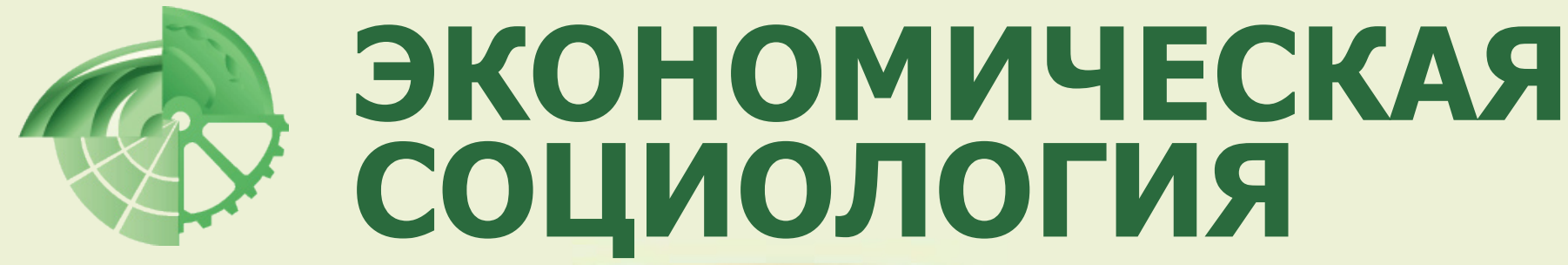

JOURNAL OF ECONOMIC SOCIOLOGY = EKONOMICHESKAYA SOTSIOLOGIYA

Читайте в номере:

Interview with

Sophie Dubuisson-Quellier.

Market Mechanism and Consumer Choice

Zabaev I., Zueva A., Koloshenko Y. Humility and The Gift:

The Elective Affinity of Institutions and Ethics in Orthodox Parishes

Зингалес Л. Капитализм для народа: как вернуть Америке утраченный ею дух процветания

Губа К. С. Издавая «СоцИс», или Проблема легитимности в советской социологии 
Экономическая

социология

T. 16. № 5 .

Ноябрь 2015

Электронный журнал

www.ecsoc.msses.ru

www.ecsoc.hse.ru

ISSN 1726-3247

\section{Адрес редакции}

101000, Россия,

г. Москва,

ул. Мясницкая,

д. 20, комн. 406

тел.: +7 (495) 628-48-86

email: ecsoc@hse.ru

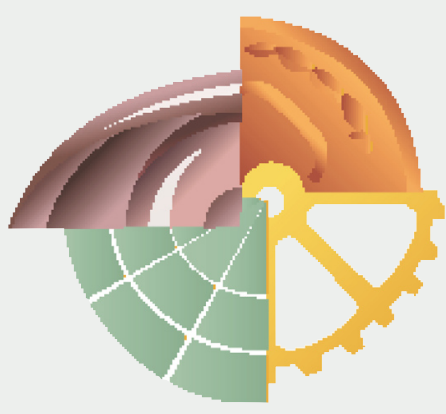

\section{Journal of Economic Sociology} Vol. 16. No 5.

November 2015

Electronic journal www.ecsoc.msses.ru www.ecsoc.hse.ru

ISSN 1726-3247

\section{Contacts}

20 Myasnitskaya street, room 406 101000 Moscow, Russian Federation phone: +7 (495) 628-48-86 email: ecsoc@hse.ru $\ni$ лектронный журнал «Экономическая социология» издаётся с 2000 г. Учредителями являются Национальный исследовательский университет «Высшая школа экономики» (с 2007 г.) и Вадим Валерьевич Радаев (главный редактор).

Цель журнала - утверждать международные стандарты экономико-социологических исследований в России, представлять современные работы российских и зарубежных авторов в области экономической социологии, информировать профессиональное сообщество о новых актуальных публикациях и исследовательских проектах, а также вовлекать в профессиональное сообщество молодых коллег.

Журнал представляет собой специализированное академическое издание. В нём публикуются материалы, отражающие современное состояние экономической социологии и способствующие развитию данной области в её современном понимании. В числе приоритетных тем: теоретические направления экономической социологии, социологические исследования рынков и организаций, социально-экономические стратегии индивидов и домашних хозяйств, неформальная экономика. Также публикуются тексты из смежных дисциплин - неоинституциональной экономической теории, антропологии, экономической психологии и других областей, которые могут представлять интерес для экономсоциологов.

Журнал публикует пять номеров в год: в январе, марте, мае, сентябре и ноябре. Доступ ко всем номерам журнала постоянный, свободный и бесплатный по адресу: http:// www.ecsoc.hse.ru. Каждый номер содержится в едином файле (10-12 п. л. в PDF).

Журнал входит в список ВАК России, индексируется в Российском индексе научного цитирования (РИНЦ).

Требования к авторам изложены по адресу: http://ecsoc.hse.ru/author_requirements. html

В журнале применяется двойное анонимное рецензирование статей. Все материалы проходят через полный цикл редакторской обработки и корректуры.

Плата с авторов журнала не взимается. Ускоренные сроки публикации статей не предусмотрены.

$\mathrm{J}$ ournal of Economic Sociology was established in 2000 as one of the first academic e-journals in Russia. It is funded by the National Research University Higher School of Economics (HSE).

Journal of Economic Sociology promotes international standards of research in economic sociology, presenting new research carried out by Russian and international scholars, introducing new books and research projects, and attracting young scholars into the field.

Journal of Economic Sociology is a specialized academic journal representing the mainstreams of thinking and research in international and Russian economic sociology. Journal of Economic Sociology provides a framework for discussion of the following key issues: major theoretical paradigms in economic sociology, sociology of markets and organizations, social and economic strategies of households, informal economy. Journal of Economic Sociology also welcomes research papers written within neighboring disciplines - new institutional economics, anthropology, economic psychology and related fields, which can be of interest for economic sociologists.

Journal of Economic Sociology has a wide Russian speaking audience, living both in Russia and abroad. Its main target group comprises research scholars, university professors, policy-makers, post-graduates, undergraduates and others who are interested in economic sociology.

Journal of Economic Sociology is a bimonthly journal released in five issues (January, March, May, September, and November). Journal of Economic Sociology provides permanent free access to all issues in PDF. Journal of Economic Sociology applies blind peer-review procedures (two referees for each research paper). All papers are subject to editing, proofreading, and professional design layout.

Guidelines for authors: http://ecsoc.hse.ru/author_requirements.html 
Экономическая социология

Т. 16. № 5.

Ноябрь 2015

Электронный журнал www.ecsoc.msses.ru www.ecsoc.hse.ru

\section{ISSN 1726-3247}

Журнал выходит пять раз в год:

№ 1 - январь

№ 2 - март

№ 3 - май

№ 4 - сентябрь

№ 5 - ноябрь

Учредители:

- Национальный исследовательский университет «Высшая школа экономики»

- В. В. Радаев

Издаётся с 2000 года

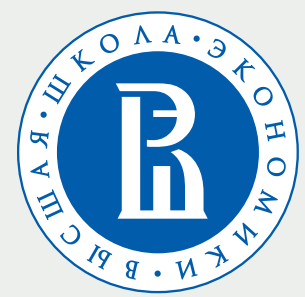

НАЦИОНАЛЬНЫЙ ИССЛЕДОВАТЕЛЬСКИЙ УНИВЕРСИТЕТ

\section{Редакция}

Главный редактор:

Редакторы выпуска:

\section{Вёрстка:}

Корректор:

Ответственный

секретарь:

Сотрудники

редакции:
Радаев Вадим Валерьевич (НИУ ВШЭ, Россия)

Соколова Татьяна Виленовна (НИУ ВШЭ, Россия)

Спенсер Сара Буссе (НИУ ВШЭ, Россия)

Мишина Мария Евгеньевна (Россия)

Андрианова Надежда Викторовна (НИУ ВШЭ, Россия)

Котельникова Зоя Владиславовна (НИУ ВШЭ, Россия)

Назарбаева Елена Алексеевна (НИУ ВШЭ, Россия)

Бердышева Елена Сергеевна (НИУ ВШЭ, Россия)

\section{Международный редакционный совет}

Ашвин Сара

(Ashwin, Sarah)

Гербер Тед

(Gerber, Ted)

Гусева Аля (Guseva, Alya)

Зависка Джейн (Zavisca, Jane)

Линднер Петер

(Lindner, Peter)

Сводер Кристофер

(Swader, Christopher)

Якубович Валерий

(Yakubovich, Valery)
Лондонская школа экономики и политических наук

(Великобритания)

Висконсинский университет в Мэдисоне

(США)

Университет Бостона (США)

Университет Аризоны (США)

Университет Франкфурта-на-Майне

им. И. В. Гёте (Германия)

Лундский университет (Швеция)

Бизнес-школа ESSEC (Франция)

\section{Редакционный совет}

\section{Богомолова}

Татьяна Юрьевна

Веселов

Юрий Васильевич

Волков

Вадим Викторович

Гимпельсон

Владимир Ефимович

Лапин

Николай Иванович

Малева

Татьяна Михайловна

Овчарова

Лилия Николаевна

Радаев

Вадим Валерьевич

(главный редактор)

Хахулина

Людмила Александровна

Чепуренко Александр Юльевич

Шанин Теодор

Шкаратан Овсей Ирмович
Институт экономики и организации промышленного производства СО РАН (Россия)

Санкт-Петербургский государственный университет (Россия)

Европейский университет

в Санкт-Петербурге (Россия)

НИУ ВШЭ (Россия)

Институт философии РАН (Россия)

Институт социального анализа и прогнозирования РАНХиГС (Россия)

НИУ ВШЭ (Россия)

НИУ ВШЭ (Россия)

Аналитический центр Юрия Левады

(Россия)

НИУ ВШЭ (Россия)

Московская Высшая школа социальных и экономических наук (Россия)

НИУ ВШЭ (Россия) 
Journal of

Economic Sociology

Vol. 16. No 5.

November 2015

Electronic journal

www.ecsoc.msses.ru

www.ecsoc.hse.ru

\section{ISSN 1726-3247}

Journal of Economic

Sociology is a bimonthly

journal released in five

issues in annual volume.

No. 1 - January

No. 2 - March

No. 3 - May

No. 4 - September

No. 5 - November

\section{Establishers}

- National Research University Higher School of Economics

- Vadim Radaev

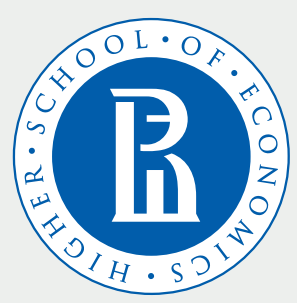

NATIONAL RESEARCH UNIVERSITY

\section{Editors}

Editor-in-Chief:

Editors:

Design and Layout:

Proofreader:

Managing Editor:

Editorial Staff:
Vadim Radaev (HSE, Russia)

Tatyana Sokolova (HSE, Russia)

Sarah Busse Spencer (HSE, Russia)

Maria Mishina (Russia)

Nadezda Andrianova (HSE, Russia)

Zoya Kotelnikova (HSE, Russia)

Elena Nazarbaeva (HSE, Russia)

Elena Berdysheva (HSE, Russia)

\section{International Editorial Council}

Sarah Ashwin

Ted Gerber

Alya Guseva

Peter Lindner

Christopher Swader

Valery Yakubovich

Jane Zavisca

\section{Editorial Council}

Tatyana Bogomolova

\author{
Alexander Chepurenko \\ Vladimir Gimpelson \\ Lyudmila Khakhulina \\ Nikolay Lapin
}

Tatyana Maleva

Lilia Ovcharova

Vadim Radaev (Editor-in-Chief)

Theodor Shanin

Ovsey Shkaratan

Yuriy Veselov

Vadim Volkov
The London School of Economics and Political Science (UK)

University of Wisconsin-Madison (USA)

Boston University (USA)

Goethe University Frankfurt (Germany)

Lund University (Sweden)

ESSEC Business School (France)

The University of Arizona (USA)

Institute of Economics and Industrial Engineering of the Siberian Branch of Russian Academy of Sciences (Russia)

HSE (Russia)

HSE (Russia)

Yuri Levada Analytical Center (Russia)

Institute of Philosophy of Russian Academy of Sciences (Russia)

Institute of Social Analysis and Forecasting, The Russian Presidential Academy

of National Economy and

Public Administration (Russia)

HSE (Russia)

HSE (Russia)

Moscow School of Social and Economic Sciences (Russia)

HSE (Russia)

Saint Petersburg State University (Russia)

European University at Saint Petersburg (Russia) 


\section{Содержание}

Вступительное слово главного редактора (В. В. Радаев)

9

\section{Тексты на русском языке}

\section{Новые переводы}

\section{Л. Зингалес}

Капитализм для народа: как вернуть Америке утраченный ею дух процветания

\section{Расширение границ}

К. С. Губа

Издавая «СоцИс», или Проблема легитимности в советской социологии. 20

\section{Дебютные работы}

\section{А. А. Долгова, Е. С. Митрофанова}

Отделение от родительской семьи в России: межпоколенческий аспект.

\section{Профессиональные обзоры}

T. С. Карабчук, А. А. Моисеева, Н. Э. Соболева

Исследование зарубежных методик и отечественных практик

определения экономического ущерба, наносимого гибелью в результате ДТП.

\section{Новые книги}

Н. В. Конрой

Где находится глобальный рынок?

Рецензия на книгу: Çalişkan K. 2010. Market Threads: How Cotton Farmers and

Traders Create a Global Commodity. Princeton; Oxford: Princeton University Press

\section{Тексты на английском языке / Articles in English}

\section{Interviews}

Market Mechanism and Consumer Choice:

An Interview with Sophie Dubuisson-Quellier.....

\section{New Texts}

I. Zabaev, A. Zueva, Y. Koloshenko

Humility and The Gift: The Elective Affinity of Institutions and Ethics in Orthodox Parishes. 


\section{New Books}

\section{E. Gudova}

"All Power to the Imagination!": A Leftist Critique of Bureaucratic Violence, Technologies and Rationality

Book Review: Graeber D. 2015. The Utopia of Rules: On Technology, Stupidity, and the Secret Joys of Bureaucracy. New York: Melville House

\section{Conferences}

\section{Spirina}

Governance, Markets and Institutions: Russia and Germany Compared 27 September - 10 October 2015, Institute for East European Studies, 


\section{Contents}

Editor's Foreword (Vadim Radaev) 9

\section{Articles in Russian}

\section{New Translations}

Luigi Zingales

A Capitalism for the People: Recapturing the Lost Genius of American Prosperity (an excerpt) 14

\section{Beyond Borders}

Katerina Guba

Editing the Soviet Sociological Journal: The Problem of Legitimacy in Soviet Sociology 20

\section{Debut Studies}

Alina Dolgova, Ekaterina Mitrofanova

Leaving the Parental Home in Russia: Intergenerational Aspects

\section{Professional Reviews}

Tatiana Karabchuk, Anita Moiseeva, Natalia Soboleva

A Review of International and Russian Methodologies

to Estimate the Economic Damage Caused by Death in the Road Accidents

\section{New Books}

Natalia Conroy

Where the Global Market Is

Book Review: Çalişkan K. (2010) Market Threads:

How Cotton Farmers and Traders Create a Global Commodity,

Princeton: Oxford: Princeton University Press.

\section{Articles in English}

\section{Interviews}

Market Mechanism and Consumer Choice: An Interview with Sophie Dubuisson-Quellier

\section{New Texts}

Ivan Zabaev, Anna Zueva, Yuliya Koloshenko

Humility and The Gift: The Elective Affinity of Institutions and Ethics in Orthodox Parishes 


\section{New Books}

\section{Elena Gudova}

"All Power to the Imagination!": A Leftist Critique of Bureaucratic Violence, Technologies and Rationality

Book Review: Graeber D. (2015) The Utopia of Rules: On Technology,

Stupidity, and the Secret Joys of Bureaucracy, New York: Melville House

\section{Conferences}

\section{Marina Spirina}

Governance, Markets and Institutions: Russia and Germany Compared 27 September - 10 October 2015, Institute for East European Studies, 


\section{VR ВСТУПИТЕЛЬНОЕ СЛОВО ГЛАВНОГО РЕДАКТОРА}

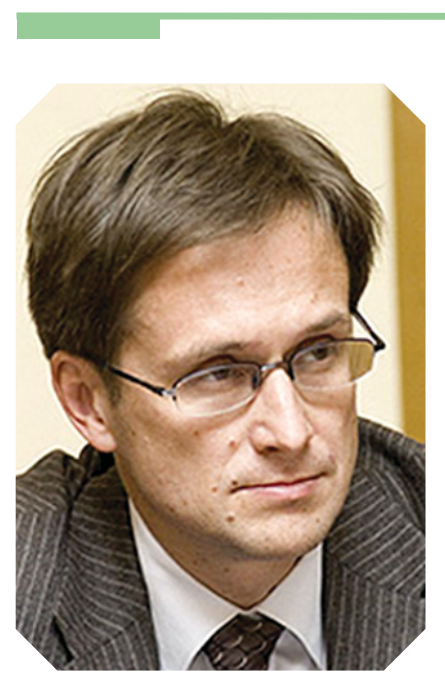

Уважаемые читатели, через месяц после выхода данного номера исполняется 10 лет с момента формального создания Лаборатории экономикосоциологических исследований (ЛЭСИ) НИУ ВШЭ (в декабре 2005 г. был выпущен соответствующий приказ). С этого времени журнал «Экономическая социология», по сути, стал одним из проектов Лаборатории. В начале следующего года мы планируем отметить эту знаменательную дату.

А пока представляем новый номер журнала.

В рубрике «Новые переводы» публикуется заключительная глава книги Луиджи Зингалеса (профессор финансов Чикагского университета) «Капитализм для народа: как вернуть Америке утраченный ею дух процветания» (Zingales L. 2012. A Capitalism for the People: Recapturing the Lost Genius of American Prosperity. New York: Basic Books). В этой книге Зингалес развивает мысль о том, что американский капитализм, некогда основанный на принципах меритократизма, превращается во всё более коррумпированную систему. Автор видит выход в поддержке свободной и открытой конкуренции, но в интересах не крупного бизнеса, а широких слоёв населения. Он утверждает, что реформы экономической политики, которые будут направлены против крупного бизнеса, станут по-настоящему прорыночными. Перевод с английского Марины Бендет. Фрагмент публикуется с разрешения Издательства Института им. Е. Т. Гайдара.

В рубрике «Расширение границ» мы публикуем статью «Издавая “СоцИс”, или Проблема легитимности в советской социологии». Её автор - K. С. Губа (научный сотрудник Центра исследований науки и технологий Европейского университета в Санкт-Петербурге, младший научный сотрудник НОЦ «Центр социально-политических исследований технологий» НИУ «Томский государственный университет»). Статья посвящена эволюции классификационного порядка в журнале «СоцИс» в 1974-1991 гг. Теоретической основой работы стала концепция институционального изоморфизма. В качестве эмпирического материала используются 7784 статьи и 160 названий рубрик журнала. Показано, как в советское время редакцией журнала решалась задача поддержания легитимности через набор рубрик, отражавших официальную идеологию советской социологии, и как менялся «СоцИс» в постсоветские годы, чтобы привлечь массового читателя.

В рубрике «Дебюты» публикуется статья А. А. Долговой (стажёр-исследователь ЛЭСИ НИУ ВШЭ) и E. C. Митрофановой (младший научный сотрудник Лаборатории социально-демографической политики, преподаватель Института демографии НИУ ВШЭ) «Отделение от родительской семьи в России: межпоколенческий аспект». Авторы пытаются ответить на несколько вопросов: как и в каком возрасте современная молодёжь покидает родительские дома в сравнении с более старшими поколениями? какие факторы влияют на возраст, в котором дети начинают жить отдельно от родителей? Используются репрезентативные данные трёх волн обследования «Родители и дети, мужчины и женщины в семье и обществе» (РиДМиЖ, 2004, 2007, 2011 гг.). Опираясь на методы анализа наступления событий (таблицы жизни и регрессии Кокса), авторы выявили нарушения межпоколенческого единообразия поведения при начале отдельного проживания.

В рубрике «Профессиональные обзоры» размещена работа T. С. Карабчук, А. А. Моисеевой $u$ H. Э. Соболевой «Исследование зарубежных методик и отечественных практик определения экономического ущерба, наносимого гибелью в результате ДТП». Обзор поднимает недостаточно обсуждае- 
мую в отечественной литературе проблему последствий низкой безопасности дорожного движения. Авторы рассматривают международный опыт оценки стоимости социально-экономического ущерба от дорожно-транспортных происшествий и сравниваются его с отечественным. Даются рекомендации по улучшению оценочного аппарата измерения социально-экономического ущерба от гибели людей в ДТП.

В рубрике «Новые книги» представлена рецензия на книгу одного из первопроходцев социальных исследований финансов Корая Чалишкана «Нити рынка: как фермеры и торговцы хлопком создают глобальный товар» (Çalişkan K. 2010. Market Threads: How Cotton Farmers and Traders Create a Global Commodity. Princeton; Oxford: Princeton University Press). В рецензируемой книге, посвящённой глобальному рынку хлопка, исследователь утверждает, что понять рынок - значит показать, как и в каких формах на нём происходит «осуществление цены». Применяя микрометоды и «многоместную этнографию», Чалишкан проводит читателя через семь «мест», последовательно показывая, как на разных уровнях агенты, опираясь на исторически и культурно обусловленные «рыночные платформы» (социально-технические сети, знания и деньги), производят разные виды индикативной (протезной) и фактической цены. Рецензия подготовлена H. B. Конрой (департамент социологии НИУ ВШЭ).

В приложение на английском языке вошли рубрики «Интервью», «Новые тексты», «Новые книги» и «Конференции».

В рубрике «Интервью» представлена беседа с профессором и научным сотрудником Софи Дюбиссон-Келье (Sophie Dubuisson-Quellier) Центра социологии организаций при Французском национальном центре научных исследований и Института политических исследований Sciences Po (Париж, Франция). Софи рассказывает о своих исследовательских интересах и последних статьях, посвящённых потребительскому поведению. Она объясняет, как социальные движения вмешиваются в работу рынков, трансформируя отношения между производителями и потребителями и оказывая давление на компании, а также указывает на широко распространённые социальные нормы, регулирующие потребление продуктов питания, и возможные санкции за их несоблюдение. Наконец, Софи делится своими взглядами на наиболее актуальные темы исследований в экономической социологии и рекомендует несколько полезных литературных источников. Интервью записано Кириллом Макаровым (ЛЭСИ НИУ ВШЭ).

В рубрике «Новые тексты» представлена статья И. В. Забаева (доцент факультета теологии Православного Свято-Тихоновского гуманитарного университета, Москва), А. В. Зуевой и Ю. А. Колошенко (научные сотрудники проекта по социологии религии Православного Свято-Тихоновского гуманитарного университета, Москва) «Humility and The Gift: The Elective Affinity of Institutions and Ethics in Orthodox Parishes» («Смирение и дар: избирательное сродство институтов и этики в православных приходах»). В работе исследуются основы хозяйственной этики современного православия. Статья опирается на серии интервью и дневниковых записях, собранных в ходе включённого наблюдения. Её главным результатом является экспликация существенных связей между этикой смирения и сетями взаимной поддержки воцерковлённых и невоцерковлённых россиян, основывающихся на логике дарообмена.

E. А. Гудова рецензирует книгу Дэвида Гребера (David Graeber) «Утопия правил: о технологиях, глупости и скрытых радостях бюрократии» (Graeber D. 2015. The Utopia of Rules: On Technology, Stupidity, and the Secret Joys of Bureaucracy. New York: Melville House). Книга представляет собой сборник статей, фокусирующихся на трёх чертах бюрократической организации: насилие, технологии и рациональность. Автор книги раскрывает антропологическое содержание бюрократических практик и технологий, характеризуемых как поле креативности и воображения. 
Мы также знакомим читателя с результатами Летней школы «Управление, рынки и институты: сравнивая Россию и Германию» («Governance, Markets and Institutions: Russia and Germany Compared»), которая была проведена 27 сентября - 10 октября 2015 г. Институтом восточноевропейских исследований Свободного университета Берлина в сотрудничестве со Школой управления «Херти» (Берлин), НИУ ВШЭ и Европейским университетом в Санкт-Петербурге при поддержке фонда «Фольксваген». Обзор подготовлен М. О. Спириной (ЛЭСИ НИУ ВШЭ).

Определена предварительная дата начала массового открытого онлайн-курса «Экономическая социология» на Российской национальной платформе открытого образования: старт намечен на февраль 2016 г. 


\section{VR INTRODUCTORY REMARKS}

Dear colleagues, almost ten years have passed since the Laboratory for Studies in Economic Sociology (LSES) was formally established at the Higher School of Economics. Since that time, many LSES fellows have contributed much to the Journal of Economic Sociology. We intend to celebrate this anniversary at the beginning of the next year.

Let us introduce the new issue of the journal.

We publish a new translation of the concluding chapter of Luigi Zingales's book "A Capitalism for the People: Recapturing the Lost Genius of American Prosperity" (New York: Basic Books, 2012). Zingales develops the idea of American capitalism being transformed from a society based upon meritocratic competition into system where merit no longer is rewarded. The author argues that it is vitally necessary to promote more open and free competition in order to bring benefits to the wider society rather than only to big business. He is convinced that real market oriented changes in economic policy should be directed against the interests of big corporations. The book is translated by Marina Bendet. The chapter is published with the permission of Gaidar Institute Publishing House.

In the section "Beyond Borders" we introduce a paper by Katerina Guba (Research Fellow at the Center for Science and Technology Studies, European University at St. Petersburg) entitled "Editing the Soviet Sociological Journal: The Problem of Legitimacy in Soviet Sociology." Journals as organizations are considered from the theoretical perspective of new institutionalism in economic sociology and the concept of institutional isomorphism in particular. As an organization, the editorial office has to solve the problem of legitimacy. The main Soviet journal "Sotsiologicheskiye Issledovaniya" (Sociological Studies) did it by matching journal headings to the official ideology of Soviet sociology. Drawing on an analysis of the journal headings for the Soviet period (1974-1991), the author argues that structural divisions of the journal space reflected legitimate meanings of Soviet sociology as a discipline, which was designed to increase the ideological and administrative efficiency of the Soviet government. Journal categories were a signal of loyalty, which was required for the organization's survival.

Alina Dolgova (Research Assistant, Laboratory for Studies in Economic Sociology, National Research University Higher School of Economics) and Ekaterina Mitrofanova (Junior Research Fellow, Laboratory of Social and Demographic Policies, National Research University Higher School of Economics) present a paper "Leaving the Parental Home in Russia: Intergenerational Aspects." The aim of the research is to examine the changes in the timing and reasons for leaving home from the perspective of four generations in Russia. In what way do today's young people leave the parental home compared with older generations? What factors influence the age at which children leave their parents' home? To answer these questions, the authors use panel data of the Russian part of Generations and Gender Survey (GGS-panel: 2004, 2007, and 2011) and applied Event history analysis (Cox regressions, Life Tables) to demonstrate that leaving a parental home depends on generation. The changes of the model of leaving home are similar to European countries experiencing the Second Demographic Transition.

Tatiana Karabchuk, Anita Moiseeva, and Natalia Soboleva provide a review of approaches of how to assess the costs of social and economic damage caused by fatalities in road accidents in Russia and other countries. The paper raises the problem of low road safety in Russia and insufficient discussion of its consequences in the literature. International experience is reviewed and compared with current Russian methodology. Recommendations are provided regarding improvement of the methods of evaluation of socio-economic damage caused by car accidents. 
The book "Market Threads: How Cotton Farmers and Traders Create a Global Commodity" by Koray Çalişkan is reviewed by Natalia Konroy (Department of Sociology, HSE). In this highly innovative book in the field of social studies of finance, the author presents an impressive example of how to study a global market using micro-methods and, in particular, multi-sited ethnography. Çalişkan chose the cotton market for his study and 'followed' cotton through seven 'sites' across Turkey, Egypt and the USA. Çalişkan introduces a view of the global cotton market as a multiplicity of regional market platforms relying heavily on 'human bridges' (i.e, networks). Agents at each end of these 'bridges' routinely generate indicative prices, these are 'prosthetic devices' designed to help agents 'on the ground' set actual prices.

\section{Texts in English}

Sophie Dubuisson-Quellier (Research Professor, Center for the Sociology of Organizations, the National Centre for Scientific Research and Sciences Po in Paris) was interviewed by Kirill Makarov. Sophie shared her research interests and gave insights into her latest recent papers dealing with consumer behavior. She illustrated the way social movement organizations interfere in market mechanisms, reshaping relations between producers and consumers and putting pressure on companies. She also outlined the most common social norms concerning food consumption and discussed possible sanctions for not adhering to them. Finally, Sophie shared her views on urgent topics in modern economic sociology and recommended several useful readings.

Following on from their article in the previous issue of this Journal, Ivan Zabaev (Associate Professor at Theology Department, St. Tikhon's Orthodox University, Moscow, Russia), Anna Zueva, and Yuliya Koloshenko (Research Fellows in the "Sociology of Religion" Seminar; St. Tikhon's Orthodox University) present their next paper, "Humility and The Gift: The Elective Affinity of Institutions and Ethics in Orthodox Parishes." The paper investigates the economic ethics of modern Orthodox laity belonging to the Russian Orthodox Church. Research is based on a series of interviews and field diary records collected from participant observation. The main result of the study is an explication of the elective affinity (Weber) between the ethics of humility and the networks of mutual support of both churched and unchurched Russians, centered in the parishes and functioning on the basis of the logic of gift giving.

The book "The Utopia of Rules: On Technology, Stupidity, and the Secret Joys of Bureaucracy" by David Graeber is reviewed by Elena Gudova (Junior Research Fellow, Laboratory for Studies in Economic Sociology; National Research University Higher School of Economics). The book presents a collection of essays focusing on three bureaucratic features: violence, technology, and rationality. Graeber provides an anthropological understanding of bureaucratic practices and technologies as a field of creativity and imagination.

Marina Spirina (Junior Research Fellow, Laboratory for Studies in Economic Sociology, National Research University Higher School of Economics) reports on the Summer School "Governance, Markets and Institutions: Russia and Germany Compared”, which was held from September 27 to October 10, 2015 by the Institute for East European Studies, Free University of Berlin (Berlin) in collaboration with the Hertie School of Governance (Berlin), German Institute for Economic Research (Berlin), Higher School of Economics (Moscow), and European University at St. Petersburg.

A preliminary date for the start of a Massive Open Online Courses "Economic Sociology" on the Russian National Platform of Open Education has been defined. The course will start at the beginning of February 2016. 


\section{НОВЫЕ ПЕРЕВОДЫ}

\section{Л. Зингалес}

\section{Капитализм для народа: как вернуть Америке утраченный ею дух процветания ${ }^{1}$}

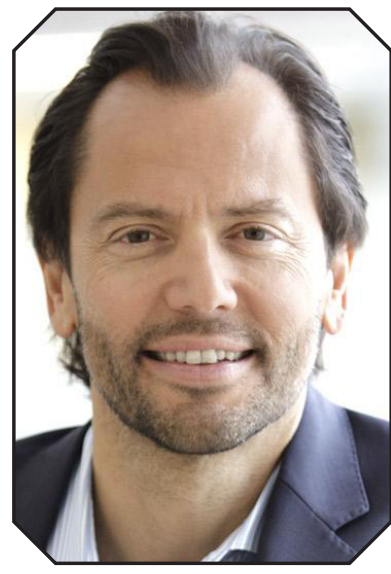

ЗИНГАЛЕС ЛУиджи (Zingales, Luigi) заслуженный профессор в области предпринимательства и финансов им. Роберта Маккормака, директор Центра им. Дж. Стиглера Школы бизнеса им. Д. Бута Чикагского университета. Адрес: США, Чикаго, 60637, ЮгВудлон-авеню, 5807.

Email: Luigi.Zingales@ ChicagoBooth.edu

Перевод с англ. Марины Бендет

Публикуется с разрешения Издательства Института им. Гайдара
Луиджи Зингалес, ныне чикагский экономист, воочию наблюдал последствия высокой инфляции и безработиџы - в сочетании с кричащим непотизмом и семейственностью - в экономике Италии, где он родился. Этот опыт оказал глубокое влияние на его профессиональные интересы, $u$ в 1988 г. он прибыл в США, вооружённый политической страстью и верой в то, что экономисты должны не просто объяснять мир, но и менять его к лучшему. В книге "Капитализм для народа» Зингалес показывает, что корни американского капитализма подверглись процессу разложения, а результатом этого становится переход к более коррумпированной системе, встречающейся в Европе и большинстве стран мира. Американский капитализм, согласно Зингалесу, вырос в уникальном инкубаторе, где меритократическая природа конкуренции способствовала возникновению веры в рынки и мобильность. Но позднее эта вера была подорвана предательством ориентированных на бизнес элит, чья лоббистская деятельность стала определять работу рынка, и это предательство произошло с молчаливого согласия интеллектуального класса. В результате все мь оказываемся перед выбором между перераспределительным популизмом и ориентированной на бизнес технократией. Однако Зингалес видит выход в прорыночном популизме, поддержке по-настоящему свободной и открытой конкуренции во благо народа, а не во благо крупного бизнеса. Отталкиваясь от истории американского популизма рубежа XX века, Зингалес утверждает, что наша нынешняя ситуация ничем не отличается от тогдашней. Средний класс и бедные беднеют, а богатые - богатеют. Решением теперь, как и тогда, должны стать выравнивающие игровое поле реформы экономической политики. Реформы, которые могут быть направлены против бизнеса (точнее, против крупного бизнеса), в действительности будут прорыночными.

Журнал «Экономическая сочиология» публикует главу 16 книги Л. Зингалеса — «За рынок, а не за бизнес» («Pro Market. Not Pro Business»), — в которой автор подводит итоги, обобщая основные идеи книги.

Ключевые слова: рыночный капитализм; демократия; социальное неравенство; государство и хозяйство; конкуренция; кризис доверия; элита; хозяйственная этика; популизм; экономическая политика.

Источник: Зингалес Л. (готовится к изданию). Капитализм для народа: как вернуть Америке утраченный ею дух проиветания. М.: Института Гайдара. Перев. с англ. Zingales L. 2012. A Capitalism for the People: Recapturing the Lost Genius of American Prosperity. New York: Basic Books. 


\section{Глава 16. За рынок, а не за бизнес}

Чего люди больше всего хотят от жизни? Материального благополучия? Благополучие важно, но не менее важна свобода, причём оба этих фактора тесно связаны между собой. Как я уже говорил раньше, интеллектуальная свобода не существует без свободы экономической; аналогичным образом экономическая свобода не может существовать без свободы интеллектуальной. В свою очередь, и экономической, и политической системам необходимы ценности, способные оправдать их существование.

После падения Берлинской стены восторжествовала демократия. Именно эта политическая модель, одержав победу в «холодной войне», обеспечила процветание Запада, позволила «азиатским тиграм» войти в число развитых стран, стала идеалом для бывших коммунистических стран Восточной Европы. В последующие 20 лет аналогичного полного идеологического триумфа добилась капиталистическая модель. Казалось, что альтернатив ей нет.

Однако интеллектуальное превосходство капитализма породило преступную беспечность и экстремизм: преступную беспечность - в связи с вырождением системы, экстремизм - в том, что касалось применения её идеологических принципов. Деньги - независимо от того, каким образом они были получены, - обеспечивали не только финансовое преуспевание, но и престиж в обществе. Представление о том, что «алчность - это хорошо», из вызывающего осуждение отступления от правил превратилось в норму. Капитализм утратил свои высокие моральные принципы.

Финансовый кризис 2007-2008 гг. и последовавшая за ним Великая рецессия спровоцировали новые споры об экономических моделях. Критики капитализма внезапно почувствовали поддержку. Они полагали, что кризис стал подтверждением того, о чём они уже давно говорили: рынки нестабильны, а их масштабные флуктуации дорого обходятся обществу. Эта позиция, прежде высказывавшаяся лишь меньшинством, оказалась преобладающей. Повсюду, от Уолл-стрита до Давоса, рассерженные толпы сторонников движения «Осcupy Wall Street» («Захвати Уолл-стрит») выступали против неравенства, против банков, против богачей - против всего на свете. Однако при этом они не выступали за что-либо конкретное. В конце концов протестующие выдвинули уже давно знакомые требования: масштабное вмешательство государства в экономику и перераспределение доходов. Эти меры уже принимались ранее: мы видели, что они не работают. В действительности вину за кризис, по крайней мере отчасти, можно возложить на государство - например, на такие его меры, как снижение ключевой ставки или стимулирование приобретения жилья, приведшие к опасному раздуванию пузыря в сфере жилищного строительства.

Однако кризис так и не сумел пробудить от спячки некоторых теоретиков свободного рынка. В попытках вернуть прошлое они переложили всё бремя ответственности с частного сектора на правительство. Они возлагали вину за кризис лишь на ипотечные агентства Fannie Mae и Freddie Mac, а также на проводимую правительством жилищную политику. Даже если правительство и было виновно в кризисе целиком и полностью, а я полагаю, что это не так, такие меры не были следствием действий правительства, направленных против финансовой сферы. Наоборот, они стали результатом интенсивного лоббирования со стороны финансовой сферы.

\section{Реальное напряжение}

Попытки натравить друг на друга деловые круги и правительство всё больше напоминают цирковую репризу, пережиток идеологических дискуссий XX века. Вернёмся к идее корпорации, размеры которой настолько велики, что она практически не сталкивается с конкуренцией на товарном рынке и при этом обладает значительным политическим влиянием. Разовьём эту идею: на что будет похожа экономика, 
основу которой составят несколько подобных компаний, - на капиталистическую или на социалистическую систему? В обоих случаях правительство будет использовать свои возможности принуждения для создания входных барьеров на рынок. В обоих случаях интересы производителей одержат верх над интересами потребителей. В обоих случаях сосредоточение экономического и политического влияния приведёт к подавлению интеллектуальной свободы, хотя, возможно, и в различной степени: эксперты и лица, формирующие общественное мнение, заложат фундамент единодушия в обществе, тогда как инакомыслящих станут жёстко обвинять в неприятии мнения большинства.

Если конкуренция отсутствует, а вся политическая власть сосредоточена в руках нескольких человек, мы имеем дело с социализмом. Если место одной крупной корпорации - государства — занимает несколько корпораций, дело обстоит, конечно, немного получше, но лишь немного. Экономическая теория учит нас, что в отсутствие множества конкурирующих между собой компаний несколько крупных корпораций в конце концов предпочтут объединиться и действовать вопреки интересам общества.

К счастью, Соединённым Штатам ещё далеко до подобной дистопии. К несчастью, наша страна всё же медленно движется в этом направлении. Мы уже видели, что на то есть множество причин, но главной из них остаётся смешение в умах общества представлений о прорыночной системе и о системе, поощряющей интересы бизнеса. Программы этих систем подчас совпадают, но их объединение способствует развитию кланового капитализма.

В реальной жизни мы сталкиваемся со следующими противоречиями: между меритократией и наследственными привилегиями; между подотчётностью и свободой действий; между свободой и властью; между свободными рынками и клановым капитализмом.

\section{Дух конкуренции}

Истинное ядро капиталистической системы - вовсе не частная собственность и не стремление к получению прибыли, а конкуренция. Частная собственность без конкуренции порождает коррумпированные монополии, тогда как конкуренция творит чудеса, максимально увеличивая благосостояние даже в ситуации, когда частная собственность ничем не защищена. Чем масштабнее политическая конкуренция, тем лучший результат она даст в политическом плане и в деле обеспечения свобод. Как наказывал нам Адам Смит (его учение подтверждает 200-летняя история экономической науки), важнейшей причиной того, почему свободные рынки обеспечивают столь значительные экономические преимущества, является конкуренция.

Однако, для того чтобы конкуренция действительно могла творить чудеса, необходимы правила. Студенты магистерской программы по управлению бизнесом в Чикагском университете исказили результаты торгов, обнаружив лазейку в системе; аналогичным образом деловые структуры, работающие по некорректным правилам, дают искажённые результаты. Но где же нам взять корректные правила? Если мы осознаем угрозу «захвата» бизнесом регуляторов, политиков и интеллектуалов, сложно понять, каким образом можно использовать государство для ограничения политической составляющей экономического влияния. Лечение может оказаться хуже самой болезни.

Я предложил в этой книге несколько решений этого парадокса. Все они в целом направлены на сокращение вмешательства государства в экономику, но лишь в тех случаях, когда отсутствие такого вмешательства способно обеспечить наиболее благоприятные результаты. К примеру, полный запрет государственных субсидий обеспечит политическую динамику, способную побороть клановость. В результате бизнес будет стремиться к контролю над налогами, а не к получению помощи от правитель- 
ства. Если какая-то проблема окажется достаточно значимой - как в случае с ролью банков в финансовом кризисе, - общество всё равно потребует вмешательства государства. Однако насколько необходимо было придавать этому вмешательству форму 2300-страничного закона Додда-Франка и 67 контрольных исследований? Почему нельзя было просто задать обществу вопрос: «Следует ли облагать налогом краткосрочное банковское финансирование?» Если бы такой прямой подход был одобрен, он устранил бы потребность в целой армии юристов и политических консультантов, нанятых для продвижения нового закона.

Точно так же, если бы конгресс продолжил устанавливать налоговые ставки, но отказался одобрить льготный режим налогообложения, это снизило бы риск искажающего политического влияния на экономику. Моё предположение, подкреплённое историческими свидетельствами, заключается в следующем: демократическое правительство лучше всего работает в ситуации, когда оно не требует от граждан слишком многого. Из всех выносимых на голосование в конгрессе вопросов внимание подавляющего большинства избирателей способны привлечь только простые вопросы, которые вызывают достаточно разногласий, чтобы по ним проводилось окончательное поимённое голосование. В том, что касается результатов такого голосования, давление общества может оказаться сильнее давления лоббистов.

\section{Подотчётность}

Подотчётность, в основе которой лежит доступ к данным правительства и бизнеса, также очень важна для защиты свободных рынков. Большинство таких данных являются собственностью компаний; те, кто их контролирует, предпринимают агрессивные попытки их защитить: информация обладает определённой ценностью; распространение данных может превратиться в незаконную их конфискацию. Однако есть простое решение. Отложенное раскрытие данных вряд ли может кому-то навредить, но при этом оно способно выявить мошеннические схемы и клановые отношения. Кроме того, сокращению масштабов клановости может способствовать вовсе не избыток новых регулирующих правительственных органов (ведь их легче всего переманить), а множество потенциальных изобличителей, приносящих пользу обществу. Однако обычно изобличители несут личные потери: их часто увольняют или подвергают остракизму. Необходимо найти способы их награждать за предоставленную ценную информацию и борьбу с корпоративным мошенничеством: это заставит ещё большее количество изобличителей обнаруживать новые пороки и недостатки.

Лучший способ борьбы с клановым капитализмом - уравнивание условий игры для лоббистов. Мы никогда не сумеем полностью уравнять их, но раскрытие данных, институт изобличителей и групповые иски, безусловно, способны радикально изменить существующее положение вещей.

\section{Рыночная этика}

Ещё одна важная составляющая программы, которую предлагает настоящая книга, - возвращение к нравственным основам капитализма и их обновление. В начале существования системы её отчасти поддерживало широко распространённое убеждение в том, что конкуренция способствует достижению лучших результатов. Это убеждение давало нравственное оправдание существованию капиталистической системы, а также создавало социальную норму, способствовавшую функционированию самого капитализма. Деньги были свидетельством успеха, но не были единственной целью экономики. Те, кто добивался успеха, нарушая правила, не получали одобрения общества.

Однако, для того чтобы капитализм мог работать подобным образом, необходимо внедрение важнейших социальных норм приверженцами свободного рынка. Несмотря на определённые перегибы, политическая корректность принесла Америке огромную пользу и способствовала значительному про- 
грессу. Борьба различных групп за равенство не шла бы столь быстро, если бы дискриминация не стала не только законодательно наказуемой, но и неприемлемой в обществе. То же верно и в случае с курением. Несмотря на широкие кампании по дезинформации населения, устраиваемые производителями табачных изделий, научная истина восторжествовала: сегодня курение активно осуждается. В этой ситуации общественные санкции оказались лучше запрета. Необходимо организовать такую же борьбу в экономической сфере. Беспринципная деятельность, приносящая вред обществу в целом, подлежит порицанию, а те, кто ею занимается, должны быть подвергнуты остракизму. Общество не одобряет спортсменов, принимающих допинг. Что же тогда говорить о более опасной форме допинга - государственных субсидиях, лоббированием которых занимаются деловые структуры? Бизнес-школы институты, более всего заинтересованные в долговечности капитализма, - могли бы приступить к организации кампании по применению рыночных норм к деловой сфере.

И последнее, но оттого не менее важное: в моей книге говорится о значительной роли, которую академические круги могли бы сыграть в борьбе за рыночную этику. Конкуренция в интеллектуальной сфере способствует тщательному анализу, требует подотчётности и прозрачности. Если эта книга сумеет положить начало обсуждению той роли, которую могли бы сыграть учёные-экономисты в качестве «стражей свободных рынков», она достигнет своей цели и вернёт Америке утраченный ею дух процветания, вернёт ей капитализм для народа. 


\title{
NEW TRANSLATIONS
}

\section{Luigi Zingales}

\section{A Capitalism for the People: Recapturing the Lost Genius of American Prosperity (an excerpt)}

\author{
ZINGALES, Luigi - \\ Robert C. McCormack \\ Distinguished Service \\ Professor of Entrepreneurship \\ and Finance, Director of the \\ George J. Stigler Center, \\ Booth School of Business, \\ University of Chicago. Address: \\ 5807 S. Woodlawn Avenue, \\ Chicago, IL 60637, USA.
}

\section{Email: Luigi.Zingales@ ChicagoBooth.edu}

\begin{abstract}
An economist at the University of Chicago, Luigi Zinagles, who was born in Italy, had a chance to observe for himself the negative consequences of high inflation and unemployment coupled with scandalous nepotism and clanship in his homeland. That experience deeply affected his professional interests. In 1988 Zingales moved to the USA, determined to prove that economists are supposed not only to explain the world but also to make it better. In his book "A Capitalism for the People" Zingales shows that American capitalism has been subjected to decay, resulting in the emergence of corrupt systems in Europe and many other countries. The American variety of capitalism developed under unique conditions of merit-based competition. Meritocratic competition contributed to an emerging trust in market and social mobility. However, this trust later was broken through the betrayal by those who were oriented to business elites, whose lobbyist groups began
\end{abstract} to affect how markets work. Intellectual classes kept silent when that betrayal happened. As a result, we have to choose between 'redistribution populism' and 'business-oriented technocracy.' However, Zingales suggests a solution associated with pro-market populism and the support of real free and open competition aimed at people's prosperity and well-being, not aimed solely at serving the interests of large business. Zingales argues that the current situation has a lot in common with American populism in the late nineteenth century. Middle and lower classes have been getting poorer while higher classes have been getting richer. Economic reforms which may make the playing field more even could serve as a solution. Reforms that could be directed against business, primarily large business, actually will turn to be pro-market, according to Zinagles.

Journal of Economic Sociology publishes the last chapter "Pro Market. Not Pro Business," in which the author summarizes his conclusions and reviews the main ideas of the book.

Keywords: capitalism; democracy; social inequality; state and economy; competition; trust crisis; elites; economy ethics; populism; economic policy.

Received: September 12, 2015.

Citation: Zingales L. (2015) Kapitalism dlya naroda: kak vernut' Amerike utrachennyy eyu dukh protsvetaniya [A Capitalism for the People: Recapturing the Lost Genius of American Proserity (an excerpt)]. Journal of Economic Sociology= Ekonomicheskaya sotsiologiya, vol. 16, no 5, pp. 14-19. Available at http://ecsoc.hse. $\mathrm{ru} / 2015-16-5 . h t m l$ (in Russian). 


\section{К. С. Губа}

\section{Издавая «СоцИс», или Проблема легитимности в советской социологии ${ }^{1}$}

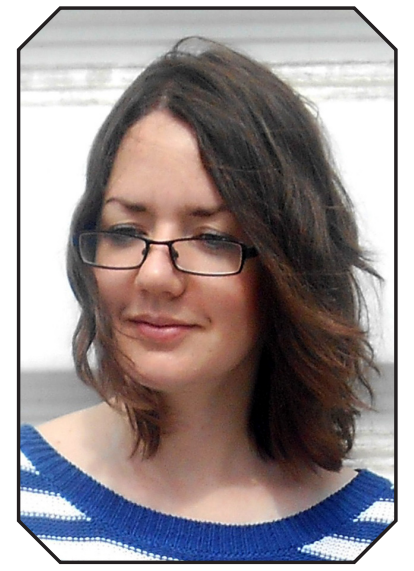

\section{ГУБА Катерина}

Сергеевна - магистр в области социологии Европейского университета в СанктПетербурге; научный сотрудник Центра исследований науки и технологий Европейского университета в Санкт-Петербурге, младший научный сотрудник НОЦ «Центр социально-политических исследований

технологий»

НИУ «Томский государственный университет». Адрес: Россия, 634050, г. Томск, пр. Ленина, 36, корп. 2.

Email: kguba@eu.spb. ru
В изентре внимания автора статьи находится эволющия классификационного порядка рубрик, которая происходила на странищах «Социологических исследований» («СоцИс») - главного журнала советской сочиологии в 1974-1991 г2. Основнылм источником эмпирических данных стали выпуски журнала за 1974-1991 г2. (всего было обработано 7784 статьи и 160 названий рубрик). Журнал «СоиИс» был создан в результате политического решения, и его существование зависело от государственного патронажа ${ }^{2}$. Журнал своим содержанием должен был соответствовать официальной идеологии советской сочииологии, что решалось набором рубрик, отсылающиих к формам работы, предписанньмм советскому социологу. Рубрикация издания служила главным сигналом о лояльности редакиии, требовавшейся для того, чтобы журнал мог продолжать своё существование. В годы перестройки, во время сочииальных и политических преобразований роль журнала была переосмыслена: “СоцИс» менялся и для того, чтобы действительно привлечь массового читателя, и для того, чтобы это стремление стало очевидным. Поставленная задача решалась с помощью воспроизводства черт успешных массовых изданий того времени - «толстых» журналов и газет. Однако сама зависимость социологии от практических задач, которые перед ней ставили партийные архитекторы перестройки, осталась. Задаваемый извне принции классификации публикачионного пространства сыграл определяюшую роль в том, как редакция организовала деятельность по поиску и отбору рукописей. Случай «СоиИса» показал, что когда перед изданием стоят чёткие задачи, связанные с содержанием, деятельность редакции подчиняется этим задачам. Работа с рукописями носила отпечаток квазирецензирования, которое выполняло функцию доведения «сырых» рукописей до тех продуктов, которые внесут вклад в

1 Работа выполнена в Центре исследований науки и технологий Европейского университета в Санкт-Петербурге при поддержке гранта Правительства РФ по постановлению №220 (Договор №14.U04.31.0001). Я признательна тем, кто разделяет мой интерес к исследованию научных журналов, - М. Соколову (ЕУСПб), всегда готовому прочитать первые черновики, Б. М. Фирсову (ЕУСПб) за консультации об ушедшей советской эпохе, Б. Степанову (НИУ ВШЭ) за помощь с поиском литературы об издании советских журналов, М. Пугачёвой (НИУ ВШЭ) за содействие в организации интервью с редакторами, принимавшими участие в работе журнала «СоцИс» в советское время.

2 Использование термина «патронаж» имеет свои отличия в исследовательской традиции истории и социологии от применения этого же понятия в государственной документации, в медицине или искусстве. Патронаж отсылает к особой специфике патронклиентских отношений, которые регулируются не только формальными правилами. В этом смысле патронаж государством журнала «СоЦис» означал как зависимость, которая была оформлена постановлениями ЦК КПСС, так и слабо формализуемую зависимость от ожиданий партии, каким должен быть журнал по советской социологии. 
нужную рубрику журнала. История советского периода существования «СоцИса» 一 это история организачии, в которой контролировалось содержание журнала, в то время как контроль внутренней работы редакции по поиску и оценке рукописей оставался на периферии.

Ключевые слова: новый институционализм; социология организаций; научные журналы; социология науки; советская социология; история социологии.

Стивена Коула как-то спросили, почему он стал заниматься социологией науки. В своём ответе Коул сослался на притягательность для него этой дисциплины в силу её лёгкого доступа к данным [Cole 2004]. Действительно, многие и многие исследования построены на анализе уже опубликованных статей, которые привлекают для изучения социальной структуры научного сообщества [Moody 2004], создания когнитивных карт [Moody, Light 2006] или описания различий между культурами разных дисциплин [Pontille 2003]. Обращаясь к публикациям в журналах за данными, исследователи имеют дело с итогом работы редакции, представленным набором статей. Вопрос о том, что стоит за составом каждого номера, как правило, остаётся на периферии внимания социологов науки. Для них журнал - это источник данных, который репрезентирует нужные феномены. Однако журнал не только как зеркало отражает состояние дисциплины [Greenfeld 1988], но и участвует в её производстве [Abbott 1999]. В данной статье мы рассмотрим журналы как феномен, который нуждается в объяснении. Нас интересует с позиций социологии организаций логика функционирования журнальных редакций, с помощью которой регулируется публикационное пространство журнала.

Статьи журнала, с которыми имеют дело читатели, а иногда и социологи науки, появляются в результате работы редакции по поиску и отбору рукописей. Соответственно значительное внимание исследователей заслужила сама процедура подготовки и издания журнала, особенности которой могут оказывать решающее влияние на то, что, в конце концов, появится на страницах журнала. В исследовании, посвящённом истории издания «American Journal of Sociology», Э. Эббот показал, как под давлением сообщества изменилась работа редакции: в соответствии с представлениями о справедливой процедуре поиска и отбора рукописей появилось так называемое слепое рецензирование всех статей с участием внешних рецензентов [Abbott 1999]. Исследование американских социологических журналов показывает, что их редакции - это тот тип организаций, в которых координационная деятельность редко затрагивает содержание статей, но в большей степени осуществляет жёсткий контроль (tight control) за различными процедурными вопросами их отбора [Meyer, Rowan 1977]. Однако такой тип контроля характерен далеко не для всех редакций.

Более важным для редакции может оказаться не строгая процедура рецензирования, а организация содержания в соответствии с миссией и целью журнала. Например, издание может определять своё предназначение в качестве главной публичной площадки для заинтересованного читателя. В этом случае редакции только помешает строгая процедура рецензирования, поскольку логика включения статей в журнал будет определяться его миссией, а не процедурой поиска и оценки рукописей.

В настоящей статье мы хотим обратить внимание на необходимость рассматривать научные журналы как организации, которые находятся под давлением внешней среды, контролирующей разные элементы работы редакций. В одних редакциях контроль происходит над внутренними производственными операциями, в других внимание сосредоточено на публикуемых материалах. Статья посвящена изучению редакции второго типа, чья деятельность определялась контролем содержания рукописей, тогда как процедура оценки рукописей находилась на периферии внимания. Тем самым мы сможем приблизиться к прояснению различий между редакциями научных журналов, которые хотя и имеют общие институциональные корни и похожи в своей формальной структуре, но различаются в своей реальной деятельности. 
Статья опирается главным образом на основные идеи культурно ориентированного институционализма, которые применяются к анализу организаций [Meyer, Rowan 1977; DiMaggio, Powell 1983 ]. В центре внимания этого подхода находятся организации, успешное существование которых зависит от одобрения их деятельности внешней средой. Логика функционирования таких организаций ставит перед ними задачу обретения легитимностиํㅜ чтто определяет всю их дальнейшую жизнь.

Организация, которая стала объектом нашего исследования, - это редакция журнала «Социологические исследования» в 1974-1991 гг. Журнал «СоцИс» был создан в 1974 г. в результате политического решения, и на протяжении советского периода его существование зависело от государственного патронажа. Само создание журнала означало высокий кредит доверия со стороны партии, который нужно было оправдывать в дальнейшем. Легитимность журнала зависела, в глазах политических кураторов, от того, насколько успешно редакция выполняла установки официальной идеологии о предназначении советской социологии. Главный тезис этой работы заключается в том, что задача достижения легитимности решалась через соответствие рубрик журнала предписанным советскому социологу формам работы. Таким образом, в центре внимания статьи находится анализ рубрик главного журнала советской социологии за 1974-1991 гг.

Статья строится следующим образом: сначала мы рассмотрим основные возможности применения новой институциональной теории для изучения академических организаций в целом и научных редакций в частности. Существующие исследования в основном затрагивали западные академические организации, поэтому мы уделим особое внимание вопросу о том, насколько правомерно использование идей нового институционализма при анализе научных организаций, занимавшихся социологией в советский период. Анализ публикационного пространства журнала предваряется описанием данных, отдельно рассматривается вопрос об ограничениях выбранной стратегии анализа. Советская социология менялась вместе с политической обстановкой, поэтому анализ делится на два исторических блока: деятельность журнала (1) до перестройки (1974-1984 гг.) и (2) в период политических перемен (1985-1991 гг.). В заключении мы возвращаемся к поставленному вопросу о координации журнальных редакций, которая может затрагивать содержание статей или процедуры поиска и отбора рукописей.

\section{Неоинституциональная теория академических организаций}

В классической работе «Институционализированные организации: формальная структура как миф и церемониал» Дж. Мейер и Б. Роуэн пишут о том, что выживание организаций зависит от того, как они выстраивают свои отношения с другими примыкающими к ним организациями (например, с поставщиками или потребителями). Если контрагенты действительно важны для существования организации, то она будет координировать свою деятельность так, чтобы эффективно решить задачи взаимодействия с ними [Meyer, Rowan 1977]. Такие организации относят к техническому сектору, для которого определяющей является эффективность координации производственных процессов, что и позволяет достигать нужных результатов. Однако в основании организационных форм лежит не только стремление организации стать эффективной, но и стремление к легитимности. Особенно это важно для организаций, которые обязаны своим существованием одобрению со стороны внешней среды (её классификационных схем и представлений). Для выживания коммерческой фирмы важно не только число потребителей её услуг, но и согласие законодателей, правоприменителей и, в конечном счёте, большинства населения с тем, что предоставление данных услуг допустимо. Рост числа публичных домов или наркопритонов ограничивается не потребительским спросом в первую очередь. На специфи-

3 В статье ключевую роль играет понятие легитимности (legitimacy). Его использование отсылает к статье Дж. Мейера и Б. Роуэна, которая строится на противопоставлении эффективности и легитимности как двух гарантий выживания организации [Meyer, Rowan 1977]. Легитимность, как отмечено переводчиками статьи в предваряющем комментарии, не стоит понимать только как «законность» - право не является единственным источником легитимности. 
ческих рынках, где стоимость товара менее очевидна и определяется социальными обстоятельствами, эти соображения становятся более важными, чем вопросы сбыта [Zuckerman 1999]. Большинство современных музеев или университетов вообе довольно мало зависят от денег, которые в них приносят непосредственные потребители их услуг. Гораздо важнее вера внешней среды - прежде всего профильных государственных органов - в то, что эти услуги должны предоставляться, а отказ организациям в поддержке нелегитимен.

Обретение легитимности предполагает наличие аудитории, одобрение которой стремится получить организация. Аудитория воспринимает окружающий мир через классификации, от попадания в которые во многом и зависит выживание организации. Классические идеи Э. Дюркгейма о социальных основаниях классификационных схем спустя десятилетия легли в основу исследований поведения организаций. Если организации входят в уже существующее поле, то им нужно вписаться в категории поля, которыми мыслят внешние акторы. Чтобы получить ассигнования и налоговые преимущества, предназначенные для университетов, организация должна в глазах бюрократов выглядеть как университет, а то, что в ней происходит, - как учебный процесс. Рособрнадзор следит за тем, чтобы не было никаких послаблений. Этот своего рода категорический императив (categorical imperative) [Zuckerman 1999] для некоторых типов организаций имеет исключительное значение, так как затрагивает легитимность существования всей организации. Если организация ему не следует, то она несёт серьёзные издержки, а так как ставится вопрос о её легитимности, то проблемы могут оказаться и более серьёзными вплоть до насильственного прекращения деятельности. Если чиновники решат, что под видом образовательных услуг оказываются какие-то другие - незаконные (например, университетом объявила себя религиозная секта или институтом сексуального мастерства — публичный дом), то в дело вмешается полиция. Классификация организации чиновником имеет решающее значение для её существования.

Таким образом, в новом институционализме присутствует особое понимание окружающей среды, которая создаёт схемы для акторов. Этот момент существен для формулировки всего аргумента, так как именно окружение накладывает ограничение на жизнь организации. Л. Цукер предложила разделить теории на два концептуальных подхода: окружение как институт и организация как институт [Zucker 1987]. В первом подходе (окружение как институт) главное - соответствие организаций внешнему окружению, которое является источником представлений о том, какими должны быть легитимные организации. Во втором подходе (организация как институт) большую роль в определении поведения организаций играют другие организации того же типа. В статье П. Димаджио и У. Пауэлла оба эти подхода совмещаются, и принудительный изоморфизм описывается через первый подход (окружение как институт), тогда как миметический изоморфизм - через второй (организация как институт) [Димаджио, Пауэлл 2010]. Институциональный изоморфизм возникает в силу того, что у организации появляются стимулы в подражании образцам, чьи успешность и легитимность не вызывают сомнения, либо тем структурам, которые определяют существование организации, настаивая на воспроизводстве необходимой формы. Димаджио и Пауэлл выделяют три механизма изоморфизма: «принудительный изоморфизм (coercive isomorphism), который проистекает из политического влияния и проблемы легитимности; подражательный изоморфизм (mimetic isomorphism), являющийся результатом стандартных реакций на неопределённость; и нормативный изоморфизм (normative isomorphism), связанный с профессионализацией» [Димаджио, Пауэлл 2010: 37].

Организация стремится попасть в нужную категорию. Для этого она совершает ряд действий, которыми отличаются организации этого типа или которые важны для внешнего окружения. Для организации существует два главных способа демонстрации своих притязаний: она может использовать символическую деятельность или же сделать акцент на формальной структуре. Во втором случае организация предъявляет форму координации своей деятельности, которая становится ареной для развёртывания ценностей, для демонстрации власти и правильного поведения, которое подтверждало бы, что орга- 
низация следует важным идеологическим конструктам [Feldman, March 1981: 177]. Например, в классической статье Д. Каменса рассматривается институциональное многообразие колледжей, которое объясняется ответом организаций на существование разных легитимационных мифов [Kamens 1977]. Типология мифов строилась на двух различиях: первое учитывало, обещают ли колледжи выпускникам, что они станут успешным пополнением элиты общества; второе принимало во внимание, являются ли колледжи агентами рекрутинга в корпоративную группу с сильными границами — религиозную или региональную. Для колледжа выбор легитимационного мифа означал выбор организационной структуры, которая использовалась как доказательство значимости организа-ции для внешнего окружения - студентов и их родителей с их разными мотивами получения высшего образования. Колледжи, обещающие выпускникам светлое будущее элиты общества, подчёркивают чередой сложных экзаменов, что далеко не всем удаётся поступить в это учебное заведение и тем более его окончить. Тем самым формальная структура выступает в своём роде доказательством предназначения организации именно для такого типа выпускника.

Согласно вышеизложенным идеям нового институционализма в первую очередь исследователь должен определить характер зависимости организации от внешней среды. Важно ли для неё внешнее окружение? Какова роль «материнской» организации и организаций такого же типа? Второе, что нужно понять: каким образом организация демонстрирует соответствие представлениям внешней среды на чём сделан акцент: на символической деятельности или на формальной структуре? И последний вопрос: какое значение это имеет для всего функционирования организации, особенно для её внутренней деятельности? Исследователи не должны останавливаться на утверждении о том, что организации следуют легитимным ожиданиям, а должны анализировать, какие изменения происходят во всей организации. Ответы на эти вопросы будут различаться для организаций в зависимости от характера их отношений с внешней средой. Применим эту логику для изучения деятельности редакции журнала «Социологические исследования» в советский этап его развития.

В социологии организаций принято считать, что академические организации относятся к тому типу, который зависит от того, насколько успешно они справляются с задачей поддержания легитимности. Для образовательных организаций остаётся неопределённым, что считать главным результатом их деятельности. Соответственно к ним в меньшей степени применима логика технической эффективности [Weick 1976] $]^{4}$. Ключевое значение приобретает институциональная среда — источник легитимационных мифов, которые делают возможным успешное существование организации [Meyer, Rowan 1977]. Формальные структуры в таких организациях стоит связывать с соображениями легитимности, но не эффективности. Если организация выполняет все правила, то считается, что она вправе оказывать те услуги, которые связаны с её деятельностью, и школы в таком случае могут выдавать аттестаты, а университеты - дипломы. Соответственно академические организации становятся особенно релевантным объектом для применения теорий нового институционализма, ведь внутренняя структура образовательных организаций в гораздо большей степени определяется правилами внешней среды, чем запросами технологического ядра [Meyer, Rowan 1977; Cameron 1984].

Однако в случае образовательных организаций СССР появляется ряд особенностей, которые не позволяют сказать, что для них отсутствовала логика технической эффективности. Организационно научные исследования были распределены по трём самостоятельным пирамидам: академическая система, возглавляемая Академией наук СССР и включающая также ряд специализированных академий и академий союзных республик; университеты и технические институты; исследовательские учрежде-ния министерств [Грэхэм 1998]. Характерная черта развития советской науки и техники - традиция государственного контроля, которая затронула и университеты, и исследовательские учреждения. Для пер-

4 Обзор основных идей нового институционализма для исследования образовательных организаций см.: [Павлюткин 2007]. 
вых планировались численность студентов, количество специальностей и программ для каждого вуза [Кузьминов, Семенов, Фрумин 2013: 15-16]. Централизованное распределение специалистов на места работы было основано на планировании потребности в специалистах согласно дробной номенклатуре специальностей, соответственно для университетов существовал чёткий план выпуска своей «продукции» [Соколов, Волохонский 2013].

Академическая система была представлена через концепцию научно-исследовательского института, которая закрепила отделение научных исследований от процесса обучения в университетах. Исследовательские учреждения также находились под контролем: советское правительство создало «систему, при которой все исследовательские учреждения стали частью огромной государственной бюрократии» [Грэхэм 1998]. Однако характер контроля различался для социальных и естественных областей знания. Те организации, которые представляли наивысший интерес для советского государства (главным образом оборонная промышленность), существовали в логике технической эффективности, им нужно было демонстрировать достижения, которые должны были носить характер легко идентифицируемых результатов. Для организаций, которые не могли предъявить достижения такого рода, контроль носил идеологический характер: «Социальные же науки и образование в области социальных наук полностью контролировались идеологически, а их развитие определялось политическими задачами “партиигосударства"» [Johnson 2008: 163] (цит. по: [Кузьминов, Семенов, Фрумин 2013: 22]).

Идеи нового институционализма позволяют описать, каким образом выстраивалась логика функционирования организаций в условиях сильного государственного контроля. Организации должны были приобрести легитимность, то есть вписаться в категории, которые были заготовлены советским правительством. Государственный патронаж - самый очевидный пример принудительного изоморфизма, под воздействием которого меняются даже такие автономные области, как наука и искусство [Useem 1976: 800]. Советская наука представляла собой административно управляемую академическую систему, в которой дисциплины должны быть вписаны в официальную идеологию предназначения науки для нужд развития советского общества. Советская социология была обязана своему появлению довольно внешним обстоятельствам, однако она все же должна была получить легитимность, сформулировав, какую пользу принесёт наука, столько десятилетий почти забытая в СССР. «Вполне оправданно будет сказать, что молчаливый союз между социологами и партией был одновременно и альянсом, и игрой, в которой каждый должен был делать уступки, и в которой у каждого было что приобрести. В партии социологи нашли для себя своих самых сильных союзников в борьбе за престиж и статус в академических кругах, но одновременно им приходилось показывать, что в их власти помогать партии в решении важных задач строительства коммунизма. Другими словами, им приходилось формулировать темы своих исследований в таком виде, чтобы ясно звучала практическая сторона, с рекомендациями для промышленного производства и для тех, кто принимает решения. Именно поэтому мы видим такой сильный уклон в социологию работы и идеологических проблем» [Beliaev, Burtorin 1982: 429].

В статье Э. Беляева и П. Бурторина подчёркивается роль КПСС в институционализации советской социологии на раннем этапе: партия в то время была самым активным агентом, который продвигал социологию в СССР. Без поддержки партийных органов не могли бы реализоваться серьёзные исследовательские начинания. Поддержка социологии имела свою выгоду для партийных функционеров не только на самом верхнем уровне, но и в местных обкомах, которые могли теперь наглядно показать, что следуют партийной инициативе, призывающей к изучению конкретной реальности [Beliaev, Burtorin 1982]. В дальнейшем интерес к социологии развивался снизу. Исследователи пишут о том, что низовое увлечение социологией стало одной из причин её дальнейшей институционализации, так как создание института и журнала как координирующих центров означало, что инициативы станет легче контролировать. Это проясняет появление журнала в 1974 г. — в нелёгкий для социологии период, когда она подверглась критике со стороны партийных органов. 
Принудительный изоморфизм развивается в ситуации, когда организация зависит от единственного поставщика ресурсов [Димаджио, Пауэлл 2010: 46]. Редакцию главного и единственного советского социологического журнала мы относим к классу организаций, которые существуют в логике сильной зависимости от «материнской» организации ${ }^{5}$. «СоцИс» был создан по модели главного журнала одной дисциплины и должен был стать отражением всего того, что официальная идеология считала советской социологией. Ожидалось, что журнал будет образцом основных форм работы советской социологии, которые включали одновременно академическую и прикладную составляющие.

Редакции научных журналов обладают двумя стратегиями, сигнализирующими о том, что издание вписывается в нужную категорию. Первая стратегия связана с их главным продуктом - содержанием журнала, которое представлено в наборе рубрик и статей. Редакторы могут выбирать, как тематически организовать публикационное пространство журнала. Они могут жёстко сформулировать названия рубрик по каким-либо принципам и неуклонно этому подчиняться, а могут вовсе отказаться от рубрик и гибко менять структуру журнала. Вторая стратегия подразумевает акцент на производственной деятельности редакции, её формальной структуре, которая становится сигналом легитимного поведе-ния организации. В этом случае редакция может показывать, как через процедуру поиска и отбора статей она следует принятому представлению о том, как должен быть устроен справедливый отбор рукописей $^{6}$. Тезис этой статьи заключается в том, что для журнала «СоцИс» релевантной оказалась стратегия, связанная с организацией публикационного пространства в соответствии с официальной идеологией о предназначении советской социологии, тогда как форма координации внутренней деятельности редакции оставалась на периферии внимания. Однако в том случае, когда имеет значение содержание журнала, это сказывается и на выстраивании формы координации деятельности журнала. Само наличие символической деятельности определяет особенности производственного процесса редакции [Meyer, Rowan 1977]. Церемониальные элементы организаций не возникают из ничего. Зачастую они требуют реорганизации всей внутренней работы организации, чтобы достичь желаемого внешнего эффекта.

Содержание журнала через классификацию рубрик должно было отразить ключевые задачи советской социологии. Рубрики стали тем сигналом, демонстрацией, заявлением и подтверждением лояльности редакции, которые требовались от неё для продолжения своей деятельности. В центре внимания статьи находится эволюция классификационного порядка рубрик, которая разворачивалась на страницах «СоцИса» с момента его создания в 1974 г. и вплоть до перехода советской социологии в постсоветскую. В заключении мы вернемся к вопросу о том, какие последствия для редакции имела необходимость выстраивания особого содержания журнала.

5 Организациям недостаточно приобрести легитимность лишь однажды, зачастую они должны соответствовать ожиданиям и дальше. Если организация этого не делает, то последствия могут быть печальными для её существования в прежнем виде. В случае журнала «СоцИс» закрытие было вовсе необязательным, но вполне вероятным можно считать смену главного редактора и редколлегии, как это случилось с журналом «Вопросы философии» [Гудков, Дубин 1994]. К сожалению, сами механизмы контроля журнала пока остаются доподлинно неописанными. В статьях, посвящённых истории советской социологии, отдельно упоминается партийный контроль, а также контроль со стороны Академии наук. Особую роль играл Отдел науки и учебных заведений ЦК КПСС, а также Отделение философии и права в Академии наук [Beliaev, Burtorin 1982]. В интервью редакторы упоминают, что сверстанные номера читались в ЦК, однако подробный анализ взаимодействия редакции и контролирующих органов пока остался без внимания со стороны историков советской социологии.

6 Пример общих американских социологических журналов показывает, что ключевое значение имеет аудитория профессиональных авторов, для которых важны прозрачность и открытость процедуры, гарантирующие справедливую оценку рукописей с обязательным «слепым» рецензированием всех рукописей и опорой на внешних рецензентов. Редакции журналов, ощущая свою ответственность, прикладывают все усилия для того, чтобы решения о судьбе рукописей были объективны. Более полно анализ случая американских социологических журналов с позиции неоинституциональной теории организаций см.: [Губа 2015]. 


\section{Данные}

Временны́е рамки исследования, как уже отмечалось, ограничиваются советским периодом: 1974-1991 гг. Ограничение вызвано стратегией анализа функционирования журнала в контексте форм работы советских социологов. Политические перемены имели своё значение и для социологии, статус которой изменился в 1990-х гг, когда завершилась её институционализация: открылись социологические факультеты, были созданы новые исследовательские центры, изменился характер финансирования и, что самое важное, появились новые социологические журналы. Всё это имело значение и для «СоцИса», поэтому этот период требует отдельного внимания со стороны исследователей. Настоящая статья основывается на следующих данных:

— все выпуски журнала «СоцИс» за 1974-1991 гг. принимались во внимание для изучения эволюции рубрик. Была составлена база данных, в которой перечислены все рубрики и количество опубликованных в них статей. Всего было обработано 7784 статьи и 160 названий рубрик. Мы также просматривали все выпуски журнала за указанный период, отмечая события, относящиеся к редакционной жизни, о которых обычно рассказывалось в рубрике «Научная хроника». К таким событиям относятся сообщения о круглых столах в редакции, её участии в социологических исследованиях, о редакционных совещаниях, отчётах редакции перед партийными органами, обсуждении журнала в органах ЦК;

- полуформализованные интервью с редакторами журнала «СоцИс». Интервью были направлены на сбор информации о том, как издавался журнал в советское время и каковы особенности его внутренней деятельности на настоящий момент. Всего было собрано восемь интервью, из которых четыре - с советскими редакторами;

— сведения об авторах журнала «СоцИс» (1975-1982 гг.): пол, научная степень, академический ранг, аффилиация с академическими институтами и университетами, местонахождение организации. Эта база данных использовалась для сопоставления, показывающего, как распределялись авторы в рубриках журнала, и позволила прояснить статусную структуру публикационного пространства ${ }^{7}$.

За скобками настоящей публикации остаётся анализ содержания самих статей. Мы исходим из того, что регулировалась в первую очередь структура журнала, оставляя относительную свободу авторам в том, как и о чём писать научные статьи. Рубрики являются тем элементом внешнего облика журнала, который легко считывается условным наблюдателем, заинтересованным в том, чтобы журнал выполнял свои функции главного печатного издания советской социологии. Отслеживание контролирующими органами содержания всех научных статей потребовало бы огромных издержек, кроме того, тексты всегда оставляли пространство для толкования позиции автора. Это не означает, что контроль за содержанием текстов отсутствовал вовсе. Свобода авторов действительно была относительной, посколь-ку существовал набор обязательных элементов, которые должны были присутствовать в научном тексте и отличали его от «нормальной человеческой речи» [Кон 2008: 15]. Однако всё же «существующий канон в виде своеобычного стиля теоретизирования оставлял место и для свободомыслия, и для школьного прилежания, и для плюрализма мнений [Батыгин 1998: 24]. Учёные умели выражать наиболее важные идеи между строк, вступая в прямую конфронтацию с системой. Возможно, следуя требованиям эпохи, структура журнала стала своего рода жертвой, которая позволила советским социологам писать научные статьи с помощью «внутренней, семантически стратифицированной речи, непроницаемой для внешнего контроля» [Фирсов 2001: 116].

7 См. подробнее: [Костенко, Яковлев 2014]. Я благодарна Веронике Костенко (НИУ ВШЭ) за любезное предоставление исходной базы данных, которая была модифицирована автором статьи для данного исследования. 


\section{«СоцИс» в первое десятилетие: период стабильности}

Официально возрождение советской социологии относят к моменту создания Советской социологической ассоциации в 1958 г., главная задача которой заключалась в представительстве советских учёных на международных конгрессах [Фирсов 2001; Соколов 2011]. Западная буржуазная наука должна была в какой-то момент услышать критику в свой адрес, поэтому руководство стало принимать приглашения от международных ассоциаций выступить с докладами от лица советской науки. Формы работы советской социологии затрагивали научную и прикладную составляющие. Необходимость принятия рациональных решений, «как того требовал основной легитимационный миф советского государства, создавала нишу, которую должна была заполнить какая-то разновидность социальных исследований» [Соколов 2011: 41]. Для рациональных решений нужно было владеть информацией о происходящем, именно социологи могли стать источником такой информации. Партийные круги особенно поддерживали прикладное предназначение социологии, которая позволяла приблизиться к решению трудных проблем индустриального управления, пропаганды и развития общества в целом [Shalin 1990]. Прикладные исследования как форма работы советской социологии не могли обойтись без научного сопровождения исследований. Должны были быть не только заводские социологи, но и те, кто писал статьи о социальной структуре советского общества или о социологии труда, а также создавал методологические и методические инструменты, которые можно было использовать в работе прикладного характера [Соколов 2011: 41]. Журнал должен был отразить на своих страницах обе ипостаси советской социологии — и научную, и прикладную её составляющие.

Прежде чем в 1974 г. появились «Социологические исследования», периодическим изданием советской социологии можно было считать семь выпусков «Социальных исследований», первый из которых вышел в 1965 г. под эгидой Института философии и Советской социологической ассоциации. Все эти выпуски не совсем соответствовали формату журнала, с каждым выпуском менялись тираж и выпускающий редактор. Отсутствовала устойчивая структура публикационного пространства, что делало выпуски в большей степени похожими на коллективную монографию.

В 1974 г. было принято постановление о создании специального периодического издания. Журнал должен был выходить четыре раза в год. В 1987 г. он стал выходить раз в два месяца, а с 1990 г. стал издаваться ежемесячно. Главным редактором стал А. Г. Харчев (работал в этой должности в 1974-1987 гг.), была создана редакционная коллегия, в которую вошли известные советские социологи, однако основную работу выполняла редакция. Функционально содержание журнала можно разделить на вводную часть (передовая статья от редколлегии), основную часть (рубрики) и заключение (рецензии и новости о конференциях и семинарах $)^{8}$. Порядок размещения рубрик указывает на символическую значимость разных разделов. Примерно также в крупных газетах выпуск открывается серьёзной аналитикой или главными новостями, а заканчивается анекдотами и кроссвордами.

\section{Стержень журнала}

Первые страницы журнала отводились так называемым передовицам, которые писались главным редактором или его заместителями и обычно оставались неподписанными ${ }^{9}$. Имя указывалось только в том случае, если номер открывался автором, который не имел отношения к редакции. В этом угадывается подражание газетному жанру — именно оттуда в журнал и пришёл сам термин [Юрчак 2014],

8 В каждом номере публиковались примерно 20 статей, несколько обзоров и коротких исследовательских заметок, а также сообщения о главных событиях в советском социологическом сообществе [Greenfeld 1988]. Л. Гринфелд выбрала для анализа 13 выпусков журнала «СоцИс» за 1974-1986 гг. Она подсчитала количество статей в рубриках, проанализировала распределение авторов и характер цитирования источников.

9 В 1974-1984 гг. вышли 42 номера; передовые статьи появились в 28 выпусках, лишь три из них были подписаны. 
которым в редакции называли открывающую номер статью. Их безличный характер отражал не мнение редакции, а установки всей советской социологии. Анонимность, кажется, только подчёркивала основательность позиции, которая высказывалась не от имени конкретного человека, но от лица всей советской социологии через её главный печатный орган.

Передовые статьи делились на два типа, каждый из которых был достаточно важен, чтобы появиться на первых страницах журнала. Во-первых, это установочные статьи, в которых постулируется роль и значение социологии для развития советского общества. Риторика воспроизводила политические образцы, текст включал ссылки на постановления партии, материалы последнего съезда, классиков марксизма. Всё это дополнялось рассказом о достижениях, обязательно присутствовал критический компонент - сообщение о том, что ещё недостаточно изучено. Статьи вроде «Советская социология накануне XXV съезда КПСС» или «Социологические исследования - на службе строительства коммунизма» дополнялись более специальными программными заявлениями о развитии социологических исследований в идеологической или хозяйственной работе. Во-вторых, на «первую полосу» журнала попадали статьи, приуроченные к важнейшим событиям символической жизни страны или к специальным задачам партийного съезда. По названиям видно, что такие статьи могли появиться и в журнале с иной дисциплинарной принадлежностью: «Победа над фашизмом и общественно-политическое развитие современного мира», «Товарищу Брежневу Леониду Ильичу», «Великий Октябрь и современное социальное развитие», «Выступление генсека ЦК Брежнева при вручении ему золотой медали им. К. Маркса». Такие материалы особенно ярко указывают на подчинённое положение дисциплины, вынужденной демонстрировать символическое единство с политической жизнью советского общества.

Далее шли рубрики, которые состояли из трёх блоков: «Теоретические проблемы социологии», «Методика и техника социологических исследований», «Прикладные исследования» - типовая трёхчастная структура, предписываемая советской эпистемологией. Субдисциплинарные деления редко нарушали установившиеся деления, лишь иногда дополняя «стержень» журнала (см. табл. 1). Простота структуры журнала во многом связана с историей появления социологии в советском пространстве, которая в 1960-е гг. возродилась в форме конкретных социальных исследований. Статус дисциплины как самостоятельной науки с собственным теоретическим аппаратом, что было привычно для западных исследователей, в советских условиях был поставлен под сомнение. Деятельность научных сотрудниковсоциологов должна была соответствовать установкам марксистско-ленинской философии. В тех обстоятельствах советская социология могла занять только подчинённое положение как конкретная прикладная наука; общей теорией ведал исторический материализм: «Считалось, что есть высший этаж социологического знания - общая теория. Ниже располагаются специальные социологии, вроде социологии труда, науки, свободного времени и тому подобное. Ещё ниже - “эмпирические”, или “прикладные”, социологические исследования» [Филиппов 2013].

Такая структура была перенесена на основные разделы журнала, которые представляли советскую социологию как дисциплину через совокупность теории, методологии и прикладных исследований ${ }^{10}$.

10 Из интервью с редактором, работавшим в «СоцИсе» в советское время:

Интервьюер. Если говорить о структуре рубрик, обсуждалось ли как-то возникновение новой рубрики? Чьей инициативой они были? Вот, например, с той же заводской социологией?

Респондент. Подспудно присутствовала идея трёхуровневого строения социологии, то есть теория, методы и эмпирическая социология. Основные рубрики из них вырастали. Всё, что было связано с практикой (вот с заводской социологией), пытались на передний план вытеснить. Естественно, как во всяком журнале, были рубрики, посвящённые научной жизни, потому что журнал должен освещать научную жизнь и выход книг. 
Список наиболее значимых рубрик (1974-1984 гг.)

\begin{tabular}{lc}
\hline \multicolumn{1}{c}{ Рубрики } & Количество статей \\
\hline Факты. Комментарии. & 183 \\
Теоретические проблемы социологии & 143 \\
Прикладные исследования & 96 \\
Методика и техника социологических исследований & 81 \\
Критика современных буржуазных социологов & 62 \\
Навстречу Всемирному конгрессу & 50 \\
Социологическая наука и практика & 41 \\
Вступительное слово-передовица & 25 \\
Социальное планирование & 20 \\
Из истории социологической мысли & 27 \\
Социология за рубежом & 22 \\
Всего & $\mathbf{7 5 0}$ \\
\hline
\end{tabular}

Соответственно теоретические статьи делились на два класса: статьи программного характера, которые посвящались положению социологии относительно истмата, и статьи, обсуждающие различные социальные феномены или социологические концепты [Greenfeld 1988]. Как пишет Гринфелд, программные статьи были похожи на материалы, публиковавшиеся в других журналах, например, в «Вопросах философии». В статьях непрограммного характера, посвящённых отдельным феноменам или концептам, присутствовала критика западной интерпретации этих феноменов или концептов и провозглашалась необходимость использования марксистско-ленинской интерпретации [Greenfeld 1988]. Рубрики с теоретическими статьями занимали самое важное место - ими журнал открывался, в них публиковались самые большие по объёму статьи, а их авторов отличал высокий академический статус. Мы проанализировали распределение авторства по разным разделам журнала за восемь лет (1975-1982 гг.) (см. табл. 2) ${ }^{11}$. Таблица сопряжённости показывает, что распределение авторов по академическому рангу не является случайным. Одни рубрики зарезервированы за авторами высокого ранга, в других появлялись статьи, даже если у автора не было учёной степени. Самым статусным оказался теоретический раздел журнала: из всех 63 статей, написанных академиками и членами-корреспондентами, 47 посвящены теории (в этом же разделе находится и самая высокая концентрация авторов - докторов наук). Следующая статусная категория - раздел с отраслевой социологией, где почти нет статей академиков, но примерно поровну статей докторов и кандидатов. Примерно то же положение занимает категория «Обзоры», куда вошли статьи, преимущественно посвящённые истории социологии и состоянию марксистской социологии за рубежом. «Методы» чуть менее статусные - статьи писались в основном

11 К категории «Теория» мы отнесли рубрики, заявленные для обсуждения теоретических и методологических проблем социологии, а также ряд рубрик, в которых публиковались статьи о состоянии дисциплины. Некоторые из этих статей были приурочены к международным конгрессам, съездам партии и отчётным конференциям Советской социологической ассоциации. В категорию «Специальные вопросы» объединены рубрики, которые публиковали статьи, посвящённые субдисциплинарным областям или отдельным эмпирическим вопросам (например, такие рубрики, как «Социальное планирование», «Социальные проблемы развития современной советской деревни», «Социологические проблемы труда и трудовых коллективов»). «Методы» и «Критика буржуазной социологии» включают одноимённые рубрики журнала. Категория «Практика» объединяет рубрики, созданные для статей об эффективности идеологической работы и производственных процессов (например, такие рубрики, как «Социологическая практика», «Социологическая наука - практике идеологической работы», «Партийная и комсомольская учеба»). Категория «Обзоры» объединяет рубрики, в которых публиковались премущественно дискуссии, размышления о новых книгах, реферативные материалы. «Прикладные исследования» включают собственно одноименную рубрику, а также небольшие исследовательские заметки, которые входили в рубрику «Факты. Комментарии. Заметки». 
кандидатами наук. Наконец, наименьшим статусом обладает категория «Прикладные исследования» со статьями аспирантов или авторов без научной степени.

Статусный порядок сохраняется, если мы посмотрим на географическое - по месту проживания авторов - распределение статей (см. табл. 3). Первое, что заметно, это доминирование в целом московских статей (636), затем идут статьи из республик (120), Ленинграда (89), регионов (72), из стран - участниц Варшавского договора (21). При этом доминирование московских статей не равномерно распределено и особенно характерно для теоретических статей и для рубрики «Критика буржуазной социологии» (77\% всех статей этой рубрики - московские), что не удивляет, ведь зарубежная литература оседала преимущественно в московских спецхранах. Разница особенно заметна между «Прикладными исследованиями» и остальными категориями - среди прикладных статей меньше половины написаны авторами из Москвы; на втором месте статьи из республик; здесь же самое заметное присутствие региональных статей. Схожие результаты о статусе разных специализаций были получены на основе данных о членстве в секциях Советской социологической ассоциации [Соколов 2015].

Таблий 2

Распределение разделов журналов в зависимости от статуса авторов статей (1975-1982 гг.)*

\begin{tabular}{|c|c|c|c|c|c|c|c|c|}
\hline \multicolumn{9}{|c|}{ Категории } \\
\hline Статус & Теория & $\begin{array}{c}\text { Специ- } \\
\text { альные } \\
\text { вопросы }\end{array}$ & Методы & $\begin{array}{c}\text { Критика } \\
\text { буржуазной } \\
\text { социологии }\end{array}$ & Практика & $\begin{array}{c}\text { Прикладные } \\
\text { исследова- } \\
\text { ния }\end{array}$ & Обзоры & Всего \\
\hline Нет & $\begin{array}{c}19 \\
(7,3 \%)\end{array}$ & $\begin{array}{c}22 \\
(20,4 \%)\end{array}$ & $\begin{array}{c}33 \\
(28,7 \%)\end{array}$ & $\begin{array}{c}16 \\
(19,8 \%)\end{array}$ & $\begin{array}{c}19 \\
(25,7 \%)\end{array}$ & $\begin{array}{c}76 \\
(28 \%)\end{array}$ & $\begin{array}{c}13 \\
(16,9 \%)\end{array}$ & $\begin{array}{c}198 \\
(20,1 \%)\end{array}$ \\
\hline $\begin{array}{l}\text { Академик, } \\
\text { член-кор- } \\
\text { респондент }\end{array}$ & $\begin{array}{c}47 \\
(18,1 \%)\end{array}$ & $\begin{array}{c}3 \\
(2,8 \%)\end{array}$ & 0 & $\begin{array}{c}4 \\
(4,9 \%)\end{array}$ & $\begin{array}{c}3 \\
(4,1 \%)\end{array}$ & 0 & $\begin{array}{c}6 \\
(7,8 \%)\end{array}$ & $\begin{array}{c}63 \\
(6,4 \%)\end{array}$ \\
\hline Доктор наук & $\begin{array}{c}107 \\
(41,3 \%)\end{array}$ & $\begin{array}{c}35 \\
(32,4 \%)\end{array}$ & $\begin{array}{c}14 \\
(12,2 \%)\end{array}$ & $\begin{array}{c}17 \\
(21 \%)\end{array}$ & $\begin{array}{c}15 \\
(20,3 \%)\end{array}$ & $\begin{array}{c}33 \\
(12,2 \%)\end{array}$ & $\begin{array}{c}24 \\
(31,2 \%)\end{array}$ & $\begin{array}{c}245 \\
(24,9 \%)\end{array}$ \\
\hline Кандидат наук & $\begin{array}{c}80 \\
(30,9 \%)\end{array}$ & $\begin{array}{c}40 \\
(37 \%)\end{array}$ & $\begin{array}{c}54 \\
(47 \%)\end{array}$ & $\begin{array}{c}38 \\
(46,9 \%)\end{array}$ & $\begin{array}{c}34 \\
(45,9 \%)\end{array}$ & $\begin{array}{c}113 \\
(41,7 \%)\end{array}$ & $\begin{array}{c}24 \\
(31,2 \%)\end{array}$ & $\begin{array}{c}383 \\
(38,9 \%)\end{array}$ \\
\hline Аспирант & $\begin{array}{c}5 \\
(1,9 \%)\end{array}$ & $\begin{array}{c}7 \\
(6,5 \%)\end{array}$ & $\begin{array}{c}10 \\
(8,7 \%)\end{array}$ & $\begin{array}{c}6 \\
(7,4 \%)\end{array}$ & $\begin{array}{c}3 \\
(4,1 \%)\end{array}$ & $\begin{array}{c}26 \\
(9,6 \%)\end{array}$ & $\begin{array}{c}2 \\
(2,6 \%)\end{array}$ & $\begin{array}{c}59 \\
(6 \%)\end{array}$ \\
\hline Неизвестно & $\begin{array}{c}1 \\
(0,4 \%)\end{array}$ & $\begin{array}{c}1 \\
(0,9 \%)\end{array}$ & $\begin{array}{c}4 \\
(3,5 \%)\end{array}$ & 0 & 0 & $\begin{array}{c}23 \\
(8,5 \%)\end{array}$ & $\begin{array}{c}8 \\
(10,4 \%)\end{array}$ & $\begin{array}{c}37 \\
(3,8 \%)\end{array}$ \\
\hline Всего & 259 & 108 & 115 & 81 & 74 & 271 & 77 & 985 \\
\hline
\end{tabular}

* Хи квадрат равен 245,319. Уровень значимости $<0,001$.

\section{Социология - практикам}

Из того, что мы знаем о советской социологии, следует: только научными её формы работы не ограничивались, но включали практическую деятельность. Развитие социологии дало надежду партийной бюрократии, что она поможет ей лучше понять такие важные вопросы, как влияние человеческого фактора на увеличение производительности труда и эффективности пропаганды [Beliaev, Burtorin 1982]. Редакция журнала «СоцИс» также стремилась внести свой вклад в решение практических задач и неоднократно писала в своих передовицах о важности внедрения в практику управления и планирования научно обоснованных социологических рекомендаций на хозяйственных предприятиях и в партийных организациях. За рекомендации предприятиям отвечали заводские социологи, с деятельностью которых связывали возможность повышения производительности рабочего труда. Партийные организации 
должны были использовать результаты исследований для улучшения пропагандистской работы. Аудитория «СоцИса» впоследствии описывалась с некоторым неодобрением: «Журнал имеет своими адресатами партийных пропагандистов (приближаясь в этом смысле к “Блокноту агитатора”) либо приобрёл функции элементарного пособия по социологии для начинающих социологов, преимущественно заводских» [Гудков, Дубин 1994].

Таблица 3

Распределение разделов журналов

в зависимости от статуса авторов статей (1975-1982 гг.)*

\begin{tabular}{|c|c|c|c|c|c|c|c|c|}
\hline \multicolumn{9}{|c|}{ Категории } \\
\hline Регион & Теория & $\begin{array}{c}\text { Специ- } \\
\text { альные } \\
\text { вопросы }\end{array}$ & Методы & $\begin{array}{c}\text { Критика } \\
\text { буржуаз- } \\
\text { ной социо- } \\
\text { логии }\end{array}$ & Практика & $\begin{array}{c}\text { При- } \\
\text { кладные } \\
\text { исследо- } \\
\text { вания }\end{array}$ & Обзоры & Всего \\
\hline Москва & $\begin{array}{c}200 \\
(77,2 \%)\end{array}$ & $\begin{array}{c}75 \\
(69,4 \%)\end{array}$ & $\begin{array}{c}79 \\
(68,7 \%)\end{array}$ & $\begin{array}{c}62 \\
(76,5 \%)\end{array}$ & $\begin{array}{c}46 \\
(62,2 \%)\end{array}$ & $\begin{array}{c}124 \\
(45,8 \%)\end{array}$ & $\begin{array}{c}50 \\
(64,9 \%)\end{array}$ & $\begin{array}{c}636 \\
(64,6 \%)\end{array}$ \\
\hline Ленингард & $\begin{array}{c}30 \\
(11,6 \%)\end{array}$ & $\begin{array}{c}13 \\
(12 \%)\end{array}$ & $\begin{array}{c}5 \\
(4,3 \%)\end{array}$ & $\begin{array}{c}4 \\
(4,9 \%)\end{array}$ & $\begin{array}{c}6 \\
(8,1 \%)\end{array}$ & $\begin{array}{c}26 \\
(9,6 \%)\end{array}$ & $\begin{array}{c}5 \\
(6,5 \%)\end{array}$ & $\begin{array}{c}89 \\
(9 \%)\end{array}$ \\
\hline Регионы & $\begin{array}{c}11 \\
(4,2 \%)\end{array}$ & $\begin{array}{c}12 \\
(11,1 \%)\end{array}$ & $\begin{array}{c}9 \\
(7,8 \%)\end{array}$ & $\begin{array}{c}3 \\
(3,7 \%)\end{array}$ & $\begin{array}{c}4 \\
(5,4 \%)\end{array}$ & $\begin{array}{c}33 \\
(12,2 \%)\end{array}$ & 0 & $\begin{array}{c}72 \\
(7,3 \%)\end{array}$ \\
\hline Республики & $\begin{array}{c}11 \\
(4,2 \%)\end{array}$ & $\begin{array}{c}7 \\
(6,5 \%)\end{array}$ & $\begin{array}{c}15 \\
(13 \%)\end{array}$ & $\begin{array}{c}7 \\
(8,6 \%)\end{array}$ & $\begin{array}{c}17 \\
(23 \%)\end{array}$ & $\begin{array}{c}59 \\
(21,8 \%)\end{array}$ & $\begin{array}{c}4 \\
(5,2 \%)\end{array}$ & $\begin{array}{c}120 \\
(12,2 \%)\end{array}$ \\
\hline $\begin{array}{l}\text { Страны - } \\
\text { участницы } \\
\text { Варшавского } \\
\text { договора }\end{array}$ & $\begin{array}{c}3 \\
(1,2 \%)\end{array}$ & 0 & $\begin{array}{c}3 \\
(2,6 \%)\end{array}$ & $\begin{array}{c}1 \\
(1,2 \%)\end{array}$ & 0 & $\begin{array}{c}4 \\
(1,5 \%)\end{array}$ & $\begin{array}{c}10 \\
(13 \%)\end{array}$ & $\begin{array}{c}21 \\
(2,1 \%)\end{array}$ \\
\hline Другое & 0 & 0 & $\begin{array}{c}2 \\
(1,7 \%)\end{array}$ & $\begin{array}{c}1 \\
(1,2 \%)\end{array}$ & 0 & 0 & $\begin{array}{c}5 \\
(6,5 \%)\end{array}$ & $\begin{array}{c}8 \\
(0,8 \%)\end{array}$ \\
\hline Неизвестно & $\begin{array}{c}4 \\
(1,5 \%)\end{array}$ & $\begin{array}{c}1 \\
(0,9 \%)\end{array}$ & $\begin{array}{c}2 \\
(1,7 \%)\end{array}$ & $\begin{array}{c}3 \\
(3,7 \%)\end{array}$ & $\begin{array}{c}1 \\
(1,4 \%)\end{array}$ & $\begin{array}{c}25 \\
(9,2 \%)\end{array}$ & $\begin{array}{c}3 \\
(3,9 \%)\end{array}$ & $\begin{array}{c}39 \\
(4 \%)\end{array}$ \\
\hline Всего & 259 & 108 & 115 & 81 & 74 & 271 & 77 & 985 \\
\hline
\end{tabular}

* Хи квадрат равен 215,662. Уровень значимости $<0,001$.

Важную роль играла рубрика «Социологическая наука и практика», которая была связана с задачей журнала отражать социологическое изучение идеологических процессов. Статьи, как уточняла редакция, предназначались пропагандистам системы партийной и комсомольской учёбы, всем изучающим курс «История КПСС», руководителям школ научного коммунизма. Редакция прилагала особые усилия, чтобы собрать материалы для этой рубрики: организовывала круглые столы, в которых принимали участие социологические центры, научные кафедры, обкомы или горкомы партии. За десятилетний период редакция приняла участие в семи круглых столах, из них три касались социальных аспектов эффективности общественного производства. В остальных случаях встречи были направлены на обсуждение социологических проблем эффективности идеологической деятельности. Редакция также регулярно встречалась с представителями партийных структур, которые использовали социологические исследования в своей деятельности. Одна из таких встреч состоялась как совещание секретарей горкомов и райкомов КПСС и работников социологических лабораторий при партийных организациях Ставропольского края. Обсуждение материалов, посвящённых проблемам идеологической работы, подчеркнуло обязанности журнала как посредника между научными учреждениями и практическими работниками [Научная хроника 1979: 229]. 


\section{Борьба с «буржуазной» социологией}

Одной из заявленных задач журнала провозглашалось развитие «идеологического сотрудничества братских партий и народов стран социалистического содружества, совместной идейно-теоретической деятельности по укреплению интернациональной духовной общности, усилению борьбы против буржуазной идеологии социал-реформизма, маоизма и ревизионизма» [Развитие... 1974: 3-11]. Редакции нужно было прояснить статус отношений советской социологии с другими социологиями, развивающимися в иных политических устройствах. Граница проводилась в политическом про-странстве, которое делилось на социалистические и капиталистические государства. Были также разграничены исторические периоды, поэтому необходимо было решить, каким статусом наделять дореволюционную российскую социологию. Редакция использовала три стратегии для того, чтобы демонстрировать свой отпор «буржуазной» науке.

Во-первых, символически важную роль играла рубрика «Навстречу Всемирному конгрессу», которая появлялась задолго до самого конгресса как подготовка к выступлению перед социологами из «буржуазных» стран. Рубрика должна была показать успешную роль советских социологов, которым партия доверила представительство на чужой — враждебной - политически площадке. Советская социология была возрождена в том числе и для того, чтобы продемонстрировать «буржуазным» учёным собственные успехи. На страницах журнала публиковались программные доклады советских социологов, участников конгрессов. Символическая значимость этой задачи подтверждается тем, что в структуре журнала эта рубрика занимала самое важное место — располагалась на первых страницах.

Во-вторых, осуществлялся критический разбор «буржуазных» социологических концепций, делался акцент на проблемах капиталистического общества ${ }^{12}$. Наступление велось через рубрику «Критика современных буржуазных социологов», а также в статьях раздела «Социальные проблемы современного буржуазного общества», который должен был раскрыть все беды капитализма. В рубрике появлялись переводы статей западных авторов, если эти статьи повествовали о таких проблемах, как алкоголизм, наркомания, неравенство и т. д. Однако чаще в рубрику входили обзоры этих проблем, сделанные советскими авторами по материалам западных источников.

Третья стратегия была связана с сотрудничеством между советскими социологами и блоком социалистических стран. Рубрика «Социологическая мысль за рубежом» была предназначена только для авторов из социалистических стран Восточной Европы. Основной массив публикаций состоял из рукописей социологов из Болгарии, Венгрии, Германской Демократической Республики, Румынии и Чехословакии. На страницах «СоцИса» легитимно зарубежная социология могла существовать лишь как продолжение советской социологии ${ }^{13}$.

Политические тонкости следовало принимать во внимание не только при классификации авторов одной эпохи, но и при обращении в прошлое, когда нужно было решить, может ли та или иная книга или статья входить в социологическое наследие. Легитимным было писать статьи о Н. Г. Чернышевском, А. В. Луначарском, С. Г. Нечаеве или о первых социологических исследованиях бюджетов времени, труда и воспитания, половой морали 1920-1930-х гг. Основной массив статей указывает на стремление

12 О важности классовой позиции, когда социологические работы дифференцировались в зависимости от того, чьи интересы и взгляды выражали их авторы, см.: [Фирсов 2001: 66].

13 На это указывает набор зарубежных социологических журналов, содержание которых публиковалось в конце номера для знакомства с исследовательскими направлениями. В этот список не входит ни один западноевропейский журнал, не говоря уже об американских изданиях. Во многих других советских гуманитарных журналах происходило то же самое. Например, «Вопросы философии» и «Философские науки» делали рецензии и обзоры из социологических журналов только социалистических стран [Weinberg 2004: 49]. 
выстроить историю, скорее, марксистской социологии. Для этих целей едва ли подходили французские или немецкие тексты основателей социологии, которые были ответственны за появление социологии в её «буржуазном варианте». Русская же социология также едва могла быть использована, например, тексты П. А. Сорокина впервые появились в журнале только в 1987 г. с осторожной сопроводительной статьёй от имени редакции ${ }^{14}$. Описанный выше способ представления зарубежной и «буржуазной» социологии начинает размываться уже во второе десятилетие существования журнала, когда на его страницах появляется всё больше переводов так называемых буржуазных авторов. Переводы или критические статьи должны были тем не менее сопровождаться ссылкой на существование методологических принципов оценки трудов западных обществоведов с целью усвоения их «позитивных завоеваний».

Итак, логика появления и исчезновения рубрик показывает предзаданность основных направлений главными партийными задачами - такими как идеологическая деятельность, управление народным хозяйством, борьба с буржуазной социологией. Новый период в развитии советского общества переориентировал деятельность журнала на новые темы, которые, однако, не противоречили кардинальным образом условиям государственного патронажа.

\section{Перестройка общества - перестройка журнала}

В 1986 г. прозвучал призыв Т. И. Заславской, президента Советской социологической ассоциации, превратить социологию в инструмент перестройки. Она критиковала советскую социологию за отсутствие интереса к формированию нового курса - место социологов было занято писателями и художниками [Shalin 1990]. В последующие несколько лет советские социологи, однако, с энтузиазмом приняли участие в формировании политической повестки страны: «Советские социологи... претендо-вали на специальный статус для своей науки, видя в ней инструмент социальной реконструкции» [Shalin 1990: 1024]. Взамен они получили завершение институционализации. Самой важной датой в этом процессе стало постановление ЦК КПСС «О повышении роли марксистско-ленинской социологии в решении узловых социальных проблем советского общества» (июнь 1988 г.), которое показало, что партия поддерживала стремление социологов помочь перестройке [Shalin 1990]. Это постановление санкционировало переименование Института социологических исследований в Институт социологии, дало разрешение на увеличение количества выпусков «СоцИса» (журнал вскоре стал ежемесячным). Ведущим университетам было предписано открыть учебные программы по социологии, разработать учебный план, подготовить и выпустить учебную литературу. В постановлении речь также шла о создании Центра по изучению общественного мнения [О повышении роли... 1988]. Зелёный свет был дан всему, что было упущено в предыдущие десятилетия.

Роль журнала в происходящих процессах постулировалась как «надёжный инструмент перестройки». При такой постановке задачи социология превращается в инструмент преобразований, не только поставляющий социальную экспертизу происходящих реформ и процессов, но и разрабатывающий отдельные вопросы и направления перестройки. Политические перемены далеко не для всех журналов по социально-гуманитарным наукам означали стремление в них поучаствовать. Многие издания сохранили ориентацию на узкую академическую специализацию, однако от журнала советской социологии ожидалось, что он не останется в стороне от широко обсуждаемых процессов ${ }^{15}$. Социологи должны

14 С 1987 г. редакция начинает публиковать материалы, посвящённые П. А. Сорокину, в частности его переписку. Подборке писем предшествовало небольшое вступление, в котором указывалось на признание Сорокиным «прогрессивноисторического значения социалистических преобразований в стране». Кроме того, цитировалось мнение В. И. Ленина о П. Сорокине: «Мысли Сорокина помогут советским и зарубежным специалистам глубже, объективнее осмыслить его сложное и противоречивое наследие» [Социологическое наследие 1987: 45].

15 В конце 1980-х гг. тиражи научных социально-гуманитарных журналов в основном падали. Например, «Вопросы истории естествознания и техники» - падение тиража почти вдвое, «Вопросы литературы» — на 40\% [Гудков, Дубин 1994]. 
были создать целостный проект перестройки социальной сферы, а также проанализировать социальные аспекты демократизации [Быть в авангарде перестройки 1988: 3-5]. В 1988 г. при обсуждении новых задач журнала был сформулирован ряд требований: «Первое - содействие перестройке в нашей стране, в том числе и в общественных науках; второе - профессионализм в подготовке материалов; третье - доступное для широкого читателя изложение» [Каким быть журналу 1988: 138-139].

Структура рубрик за этот период показывает, каким образом воплощалась заданная журналу роль «инструмента перестройки». Изменения происходили не сразу, захватывали самые разные рубрики, начиная с передовых статей и заканчивая переориентацией традиционных разделов. Первая передовица о перестройке появилась в третьем номере журнала за 1987 г. и называлась «Социология в контексте революционной перестройки общества». С этого времени тематика рубрик начинает дополняться, возникают новые разделы, одни - на протяжении всего периода перестройки, другие - лишь в нескольких номерах (см. табл. 4, 5). Распределение по годам количества рукописей, опубликованных в «перестроечных» рубриках, показывает, когда зарождался интерес к политическим преобразованиям, когда он достиг своего предела, а когда началось снижение интереса к этой тематике.

Таблица 4

Список наиболее значимых рубрик (1985-1991 гг.)

\begin{tabular}{lc}
\hline Рубрики & Количество статей \\
\hline Факты. Комментарии. Заметки & 178 \\
Прикладные исследования & 143 \\
Социологическое наследие & 75 \\
Социология за рубежом & 51 \\
Дискуссии & 39 \\
Методология СИ (разные рубрики) & 38 \\
Консультации & 29 \\
Навстречу ХХVІІ сьезду КПСС & 28 \\
Социологическое обеспечение экономической ре- & 23 \\
формы & 22 \\
Социальные проблемы зарубежных стран & 21 \\
Социальные реалии вчера и сегодня & $\mathbf{6 4 7}$ \\
\hline Всего &
\end{tabular}

Постоянные рубрики «Теоретико-методологические проблемы», «Методика и техника социологических исследований», «Прикладные исследования» остались стержнем журнала, правда, подверглись изменениям. Сохранился отдельный раздел с теорией, однако статей в нём стало намного меньше (всего было опубликовано 12 статей) ${ }^{16}$. Место теории фактически заняли новые перестроечные рубрики. Сравнение списков самых популярных рубрик за два разных периода - 1974-1984 и 1985-1991 гг. (см. табл. 1, 4) - показывает, что взаимные пересечения остались между рубриками «Факты», «Прикладные исследования», «Социология за рубежом» и «Социологическое наследие», если материалы этой последней рубрики приравнять к «Истории социологической мысли». Однако количество публикаций заметно различается. Многие рубрики первого периода существования журнала или вовсе ушли, или не попали в основной список, поскольку в них печаталось мало статей. Среди исчезнувших разделов - «Критика буржуазной социологии», «Социологическая наука и практика», «Социальное планирование» и передовые статьи, раньше публиковавшиеся в начале почти каждого выпуска ${ }^{17}$.

16 В таблице 4 не отражена эта рубрика, так как находится в низу всего списка рубрик.

17 Статьи, посвящённые западной социологии, продолжали печататься в журнале, но теперь они располагались в иных рубриках, например, в разделах «Социологическое наследие» и «Социология за рубежом», ранее зарезервированных для классиков марксистской мысли и исследователей из дружественных СССР стран. 
Таблий 5

\section{Новые «перестроечные» рубрики (1987-1991 гг.)}

\begin{tabular}{|c|c|c|c|c|c|}
\hline \multirow[t]{2}{*}{ «Перестроечные» рубрики } & 1987 & 1988 & 1989 & 1990 & 1991 \\
\hline & \multicolumn{5}{|c|}{ Количество статей } \\
\hline Преподавание общественных наук: пути перестройки & 2 & & & & \\
\hline $\begin{array}{l}\text { Навстречу XIX партконференции: теория и практика соци- } \\
\text { альных преобразований }\end{array}$ & 3 & 14 & 6 & & \\
\hline Передовые статьи & 2 & 4 & 1 & & \\
\hline Демократизация общественной жизни & & 7 & 2 & 8 & 2 \\
\hline Политика. Демократия. Личность & & & 8 & 4 & 1 \\
\hline Теория и практика социальных преобразований & & & 1 & & \\
\hline Общественная трибуна учёного & & & 1 & & \\
\hline Социологическое обеспечение экономической реформы & & & & 16 & 7 \\
\hline Трибуна депутата & & & & 1 & \\
\hline Всего & 7 & 25 & 19 & 29 & 10 \\
\hline
\end{tabular}

С наступлением гласности исчезла необходимость во многих рубриках. Критика буржуазной социологии была связана с идеологическими задачами противостояния капиталистическому устройству общества. Рубрика «Социология и практика» отсылала к применению социологических исследований в идеологической работе идейно-воспитательного характера. «Социальное планирование» связывало социологию с возможностями эффективного управления народным хозяйством. Все эти задачи для советской социологии, ранее прописанные в партийных документах, постепенно теряли свою актуальность. Вместе с тем теряло смысл и сохранение этих рубрик, что не означало полное отсутствие связи с практической составляющей советской социологии. Скорее, эта составляющая получила иное наполнение, связанное с перестройкой. Новый облик журнала по-прежнему соответствовал политическим задачам, а не концептуальным различиям социологии как науки. Происходило это одновременно с сокращением количества статей в традиционных рубриках, посвящённых теории и методологии социологических исследований. Журнал стал чаще выходить: шесть номеров вместо четырёх в 1986 г. и двенадцать вместо шести в 1990 г. Но, несмотря на увеличившееся количество номеров, редакция публиковала всё меньше и меньше рукописей по теории и методологии. Даже если объединить различные вариации «методологических» рубрик в одну категорию, общее количество рукописей не превысит 40 публикаций за период перестройки, в то время как за первый период существования журнала их появилось вдвое больше.

Ориентация на широкий круг читателей не ограничивалась только новыми темами, связанными с политическими процессами. Новым читателям нужны были сюжеты со своей долей волнующего и ранее запретного: «За читателя приходится бороться, вводя, в частности, и некоторую публицистичность» [Каким быть журналу 1988: 138-139]. Новое содержание связывалось с рубрикой «Социологическая публицистика», которая впервые появилась в 1985 г. Её главным отличием стали статьи на темы, за которые редко брались социологи. Редакция не делала никаких попыток встроить их в социологический канон советского образца; статьи писались как заметки или рассказ о собственном опыте. Иногда авторы пользовались письмами с историями из жизни, которые обычные люди присылали в центральные газеты. Для многих читателей публицистическая рубрика являлась одним из самых интересных разделов журнала (о чём можно судить по опубликованным письмам читателей); в ней печатались такие материалы: статья о молодёжи «По ком звонит колокольчик»; «Узы брака и узы свободы» — итог «включённого наблюдения» и анализа писем, пришедших в ответ на одну из публикаций в массовом издании; «Феномен анонимки» - текст, который построен на рассказах о роли анонимок в жизни отдельных 
людей. Две статьи носили ещё более провокационный характер; одна называлась «Под страхом ужаса» и была посвящена нарушению закона сотрудниками правоохранительных органов; вторая — «Короли и пешки» - касалась неуставных отношений в советской армии и собрала много читательских откликов, которые приходили и месяцы спустя после выхода статьи.

В первое время основными авторами публицистических материалов были журналисты и писатели. Социологи признавали, что их собственные статьи тоже должны привлекать внимание, подозревая, что журналисты и писатели вторгаются в область, которую советские социологи хотели бы оставить за собой: «К сожалению, уровень работы социологов пока значительно ниже того, на котором анализируют действительность наша публицистика» [Каким быть журналу 1988: 140]. В последующие годы в журнале появится рубрика, в которой сконцентрировалось всё самое волнующее читателя эпохи перестройки, а также начинает меняться облик традиционных рубрик. В них публиковались статьи, посвящённые новым проблемам общества. Их отличали громкие заголовки, сразу привлекающие внимание: «За колючей проволокой - другая жизнь», «Наркотики в армии», «Преступная страсть». Попытки увлечь читателя были самыми разнообразными ${ }^{18}$. Например, редакция публиковала провокационные воспоминания пенсионера А. Т. Рыбина об И. В. Сталине, главы из книги Э. Карнеги, социологический юмор и даже кроссворды ${ }^{19}$.

Риторически массовый читатель журнала появился ещё до начала масштабных реформ в СССР и знаменитого постановления об изменившейся роли общественных наук 1988 г. $^{20}$. Однако по-настоящему массовая аудитория у журнала возникла в разгар перестройки, когда за один месяц тираж журнала увеличился в полтора раза и дальше продолжал расти ${ }^{21}$. Внимание к массовому читателю требовало улучшения содержания и формы рукописей. В основном редакция отмечала недостатки, связанные с формой, - излишний академизм, обилие формул и таблиц и отсутствие увлекательности изложения: «Нередко отсутствие свежей мысли маскируется хитросплетением наукообразных терминов, сопровождается бездушным, маловразумительным стилем изложения» [Автор — редакция - читатель 1984: 39]. Неоднократно звучали упрёки в академической «бесстрастности» — в увлечении формальным аппаратом, который «лишь отпугивает читателя, если употребляется единственно для придания тексту наукообразия и усложнённости» [Научная хроника 1987: 122]. Редакторы предлагают авторам писать более живые тексты, не только и не столько ориентируясь на «Социологические исследования» как на научно-информационное издание, сколько рассматривая его в качестве общественно-политической трибуны.

Итак, в годы социальных и политических преобразований роль журнала была переосмыслена, что связано с перестройкой журнала вместе со всем остальным обществом. «СоцИс» менялся на глазах, однако зависимость самоопределения социологии от практических задач оставалась неизменной. Те-перь такие задачи ставили партийные архитекторы перестройки. Как и в ранний период существования, в издании отсутствовали иные принципы классификации рубрик. В изменениях большую роль сыграла

18 Появление таких статей не в последнюю очередь зависело от предприимчивости главного редактора. Вслед за нашими респондентами (редакторами, работавшими в журнале в советский период его издания) нужно особо отметить усилия Г. С. Батыгина в период перестройки, с личностью которого связывают многие перемены в журнале.

19 Примеры слов, требующих угадывания: «немецко-американский социолог» и «моющее средство».

20 В 1984 г. редакция выпустила передовицу о самом журнале, где перечислила своих подписчиков: социологи из научных центров и университетов, различных отраслей народного хозяйства, партийные и комсомольские работники, хозяйственные руководители, преподаватели философии, научного коммунизма и других обществоведческих дисциплин. Среди массовых читателей упоминались рабочие, колхозники, инженеры, рядовые сотрудники аппарата управления, учителя, журналисты, работники культуры и военнослужащие. Своей дальнейшей целью редколлегия ставила «превращение журнала в собеседника как можно более широкого круга читателей» [Автор — редакция — читатель 1984: 39].

21 Максимальный тираж составил 29986 экземпляров в 1989 г. (№ 4). Журнал продавался в киосках [Shalin 1990]. 
ориентация на массового читателя, которая привела журнал к заметной публицистичности. Редакция стремилась к тому, чтобы статьи были понятны и интересны читателям, которые никак не были связаны с социологией. Обращения редакции к авторам можно всерьёз рассматривать как призывы к тому, что сейчас называют публичной социологией.

\section{Вместо заключения}

Легитимность журнала «Социологические исследования» поддерживалась тем, насколько он мог воплощать классификационный порядок, характерный для советской социологии. Государственный патронаж, сделавший возможным возрождение социологии в СССР, имел свою цену: дисциплина должна была встраиваться в заданные извне категории. «Расплатой» стало воплощение на страницах журнала схем, предназначенных для социологии партийными документами или связанных с политическими процессами перестройки. Можно возразить, что структура рубрик играла роль декораций. Государственный патронаж, однако, трудно исчерпать лишь риторикой. Декорации не возникают из ничего и зачастую требуют изменения всей внутренней работы организации, чтобы достичь желаемого внешнего эффекта [Meyer, Rowan 1977]. Обращаясь к анализу организаций, чьё функционирование зависит от внешнего одобрения, исследователи стремятся рассмотреть, с какими последствиями сталкиваются такие структуры, добиваясь легитимности. Для редакции «СоцИса» задаваемый извне принцип классификации публикационного пространства стал определять стратегию поиска и отбора рукописей.

Отбор рукописей, взаимодействие между редакцией и авторами является типичной задачей, которая сопровождается трансакционными издержками [Норт 1993]. Ограниченные ресурсы нужно распределить между разными задачами - поиском, оценкой и подготовкой рукописи к печати. При этом каждая из этих задач конкурирует между собой, а приоритет одной из них делает второстепенными другие. Если редакции исключительно важно наполнить рубрику, но авторы не спешат писать для неё, то журнал будет искать самостоятельно авторов, организовывать события, по результатам которых можно получить тексты. Задача прописывания классификаций, сигнализирующих о лояльности редакции, определяла способ заполнения рубрик статьями. Было трудно спрогнозировать, придут ли в этом месяце необходимые рукописи, поэтому редакция не могла занимать только выжидательную позицию и проводила круглые столы, направленные на обсуждения важных вопросов, встречи с читателями и агентами, заинтересованными в социологической информации, и даже организовывала собственные социологические исследования. Такие усилия предпринимались и в период ранней истории «СоцИса», когда события были направлены на обсуждение проблем эффективности общественного производства и идеологической деятельности, и во время перестройки.

В ситуации принудительного изоморфизма манёвры редакции в основном были связаны с поиском рукописей, которые не всегда соответствовали требованиям редакции, поэтому им необходима была серьёзная доработка. Заполучив желанные рукописи, редакция делала всё возможное, чтобы довести их до нужного состояния и подготовить к публикации. Повседневная жизнь редакции, рабочие операции по превращению полученных рукописей в статьи журнала, несла отпечаток стоящих перед журналом задач. Редактировался не только стиль изложения, но менялись структура рукописи, теоретические подходы и даже научные источники. Приведём цитату из редакционной колонки, которая иллюстрирует подход к подготовке рукописей: «Характерен следующий факт: лишь каждая четвёртая статья проходит “доводку”, равнозначную научному и литературному редактированию. Что же касается подавляющего большинства материалов, то речь идёт об изменениях логики изложения и интерпретации данных, об основательной перестройке языка и стиля изложения» [Автор — редакция — читатель 1984: 39].

Работа с рукописями, таким образом, носила отпечаток квазирецензирования, которое несло не тот смысл, как в случае, например, американских журналов [Губа 2015]. Оно не было похоже на процедуру 
вынесения дисциплинарного вердикта, но, скорее, выполняло функцию доведения сырых рукописей до состояния тех продуктов, которые станут приемлемыми образцами социологической работы. Мы видим, что в том случае, когда стоят чёткие задачи, связанные с содержанием журнала, внутренняя работа редакций подчиняется этой задачи. Вероятен такой эффект для всех редакций, которые находятся в ситуации контроля публикационного пространства (даже если этот контроль вызван другими причинами). Если перед редакцией стоит задача сделать журнал, формат которого заранее определён, то необходимо предоставить ей свободу действий в поиске и оценке рукописей. Едва ли редакция справилась бы, если бы перед ней стояли чёткие задачи, связанные с содержанием статей, но одновременно строго контролировалась процедура отбора рукописей.

\section{Литература}

Автор — редакция - читатель. 1984. Социологические исследования. 3: 34-43.

Батыгин Г. С. 1998. Преемственность российской социологической традиции. В сб.: Ядов В. А. (ред.). Социология в России. М.: Издательство Института социологии РАН; 23-44.

Быть в авангарде перестройки. 1988. Сочиологические исследования. 1: 4-5.

Грэхэм Л. 1998. Очерки истории российской и советской науки. М.: Янус-К.

Губа К. 2015. Поиск и отбор рукописей в американских социологических журналах: сеть vs рынок. Сочиология власти. 3: 93-125.

Гудков Л., Дубин Б. 1994. Литература как сощиальный институт. М.: Новое Литературное обозрение.

Димаджио П., Пауэлл У. 2010. Новый взгляд на «железную клетку»: институциональный изоморфизм и коллективная рациональность. Экономическая социология. 11 (1): 34-57. URL: http://ecsoc.hse. ru/2010-11-1/26595675.

Каким быть журналу. 1988. Социилогические исследования. 3: 138-142.

Кон И. С. 2008. Восемьдесят лет одиночества. М.: Время.

Костенко В. В., Яковлев Г. А. 2014. Состав авторов журнала «Социологические исследования», 1975-1982 гг. Соичиологические исследования. 9: 123-130.

Кузьминов Я. И., Семёнов Д.С., Фрумин И.Д. 2013. Структура вузовской сети: от советского к российскому «мастер-плану». Вопросы образования. 4: 8-69.

Научная хроника. 1987. Социологические исследования. 1: 122.

Норт Д. 1993. Институты и экономический рост: историческое введение. THESIS. 1: 69-90.

О повышении роли марксистско-ленинской социологии в решении узловых проблем советского общества. 1988. Социологические исследования. 5: 3-5. 
Павлюткин И. В. 2007. Что может сказать новый институционализм о поведении образовательной организации? В сб.: Семёнова М. В. (ред.). Экономика университета: институты и организации. М.: Изд. дом ВШЭ; 151-167.

Развитие социологических исследований в СССР и задачи журнала. 1974. Социологические исследования. 1: 3-11.

Соколов М. 2011. Рынки труда, стратификация и карьеры в советской социологии: История советской социологической профессии. Экономическая социология. 12 (4): 37-42. URL: http://ecsoc.hse. ru/2011-12-4/42287242.html

Соколов М. 2015. Демографические и социальные профили субдисциплин в советской и российской социологии. Социологические исследования. 9: 49-56.

Соколов М., Волохонский В. 2013. Политическая экономия российского вуза. Отечественные записки. 4 (5): $25-33$.

Социологическое наследие. 1987. Сочиологические исследования. 5: 45-55.

Филиппов А. Ф. 2013. Советская социология как полицейская наука. Новое Литературное обозрение. 123: 48-63.

Фирсов Б. М. 2001. История советской соичиологии 1950-1980-х годов. Курс лекций. СПб.: Издательство «Европейский университет в Санкт-Петербурге».

Юрчак А. 2014. Это было всегда, пока не кончилось. Последнее советское поколение. М.: Новое Литературное обозрение.

Abbott A. 1999. Department and Discipline: Chicago Sociology at One Hundred. Chicago: The University of Chicago Press.

Beliaev E., Burtorin P. 1982. The Institutionalization of Soviet Sociology: Its Social and Political Context. Social Forces. 61 (2): 418-435.

Cameron K. S. 1984. Organizational Adaptation and Higher Education. Journal of Higher Education. 55 (2): $122-144$.

Cole S. 2004. Merton's Contribution to the Sociology of Science. Social Studies of Science. 34 (6): 829-844.

DiMaggio P., Powell W. 1983. The Iron Cage Revisited: Institutional Isomorphism and Collective Rationality in Organizational Fields. American Sociological Review. 48: 147-160.

Greenfeld L. 1988. Soviet Sociology and Sociology in the Soviet Union. Annual Review of Sociology. 14: 99-123.

Johnson M. 2008. Historical Legacies of Soviet Higher Education and the Transformation of Higher Education Systems in Post-Soviet Russia and Eurasia. In: Baker D. P., Wiseman A. W. (eds) The Worldwide Transformation of Higher Education. Bingley, UK: Emerald Group Publishing Limited; 159-176. 
Feldman M., March J. 1981. Information in Organizations as Signal and Symbol. Administrative Science Quarterly. 26 (2): 171-186.

Kamens D. H. 1977. Legitimating Myths and Educational Organization: The Relationship between Organizational Ideology and Formal Structure. American Sociological Review. 42 (2): 208-219.

Meyer J., Rowan B. 1977. Institutionalized Organizations: Formal Structure as Myth and Ceremony. American Journal of Sociology. 83: 340-363.

Moody J. 2004. The Structure of a Social Science Collaboration Network: Disciplinary Cohesion from 1963 to 1999. American Sociological Review. 69 (2): 213-238.

Moody J., Light R. 2006. A View from Above: The Evolving Sociological landscape. American Sociologist. 37 (2): $67-86$.

Pontille D. 2003. Authorship Practices and Institutional Contexts in Sociology: Elements for a Comparison of the United States and France. Science Technology Human Values. 28 (2): 217-243.

Shalin D. 1990. Sociology for the Glasnost Era: Institutional and Substantive Change in Recent Soviet Sociology. Social Forces. 68 (4): 1019-1039.

Weick K. 1976. Educational Organizations as Loosely Coupled Systems. Administrative Science Quarterly. 21 (1): 1-19.

Weinberg E. 2004. Sociology in the Soviet Union and Beyond. Sociology. 14: 99-112.

Useem M. 1976. Government Patronage of Science and Art in America. American Behavioral Scientist. 19 (6): 785-804.

Zucker L. G. 1987. Institutional Theories of Organization. Annual Review of Sociology. 13: 443-464.

Zuckerman E. 1999. The Categorical Imperative: Securities Analysts and the Illegitimacy Discount. American Journal of Sociology. 104 (5): 1398-1438. 


\section{BEYOND BORDERS}

\section{Katerina Guba \\ Editing the Soviet Sociological Journal: The Problem of Legitimacy in Soviet Sociology}

\author{
GUBA, Katerina - MA in \\ Sociology; Research Fellow \\ at the Center for Science and \\ Technology Studies (STS), \\ European University at St. \\ Petersburg, Research Fellow at \\ the Centre for Policy Analysis \\ and Studies of Technologies, \\ Tomsk State National Research \\ University. Address: 36-2 \\ Lenin str., Tomsk, 634050, \\ Russian Federation.
}

\section{Email: kguba@eu.spb.ru}

\section{Abstract}

In this article, we consider journals as organizations from neo-institutional organizational theory (W. Powell, P. DiMaggio, J. Meyer, and B. Rowan). An editorial office as an organization has to solve the problem of legitimacy. In the case of the Soviet journal "Sotsiologicheskiye issledovaniya" ("SotsIs"), the only specifically sociological journal in the USSR, it was done by matching journal headings to the official ideology of Soviet sociology. Drawing on an analysis of the journal headings for the Soviet period (1974-1991), I argue that structural divisions of the journal space reflected legitimate meanings of the Soviet sociology as a discipline which was created for increasing the ideological and administrative efficiency of the Soviet government. Journal categories were a signal of loyalty, which was required for the organization's survival. During years of social and political changes, the role of the journal has changed. The journal has tried to attract general educated readers as well as visibly demonstrate this commitment to public issues by imitation of the evident features of 'thick' magazines and newspapers. In spite of all its changes, the journal has continued to depend on the meaning of sociology as a study of social problems. Externally given classifications have played a principal role in choosing an organizational form for searching and evaluating manuscripts. When the editorial office has clear tasks related to the content of the journal, the most appropriate form is the network form of governance because external reviewing makes it difficult to fill journal space. The organization has to use quasi-reviewing, which performs the function of bringing 'raw' manuscripts to contribute to the facade of the journal. The history of the Soviet "SotsIs" is a history of an organization, in which the content was tightly controlled, while control of the evaluation of manuscripts remained on the periphery.

Keywords: new institutionalism; organizational analysis; scientific journals; sociology of science; soviet sociology; peer review.

\section{Acknowledgements}

Funding for this research was provided by the Mega-grant of the Russian Federation Government to support scientific research under the supervision of leading scientist at the STS Center of the European University at St.Petersburg, No.14.U04.31.0001. I am indebted also to Professor Mikhail Sokolov (EUSP) who always ready to read the first drafts, Boris Firsov (EUSP) for details about Soviet sociology, Boris Stepanov (HSE) for assistance with the literature on Soviet journals, and Marina Pugacheva (HSE) for her help in arranging interviews with editors. 


\section{References}

Abbott A. (1999) Department and Discipline: Chicago Sociology at One Hundred, Chicago: The University of Chicago Press.

Avtor — redaktsiya - chitatel' [Author - Editors - Readers]. (1984) Sotsiologicheskiye issledovaniya, vol. 3, pp. 34-43 (in Russian).

Batygin G. S. (1998) Preyemstvennost' rossiyskoy sotsiologicheskoy traditsii [Continuity of the Russian Sociological Tradition]. Sotsiologiya v Rossii [Sociology in Russia] (ed. V. A. Yadov), Moscow: Izdatel'stvo Instituta sotsiologii RAN, pp. 23-44 (in Russian).

Beliaev E., Burtorin P. (1982) The Institutionalization of Soviet Sociology: Its Social and Political Context. Social Forces, vol. 61, no 2, pp. 418-435.

Byt' v avangarde perestroyki [Being at the Forefront of the Perestroika]. (1988) Sotsiologicheskie issledovaniya, vol. 1, pp. 4-5 (in Russian).

Cameron K. S. (1984) Organizational Adaptation and Higher Education. Journal of Higher Education, vol. 55, no 2, pp. 122-144.

Cole S. (2004) Merton's Contribution to the Sociology of Science. Social Studies of Science, vol. 34, no 6, pp. 829-844.

DiMaggio P., Powell W. (2010) Novyy vzglyad na "zheleznuyu kletku": institutsional'nyy izomorfizm i kollektivnaya ratsional'nost' [The Iron Cage Revisited: Institutional Isomorphism and Collective Rationality in Organizational Fields]. Journal of Economic Sociology = Ekonomicheskaya sotsiologiya, vol. 11, no 1, pp. 34-57. Available at: http://ecsoc.hse.ru/data/2011/12/08/1208204985/ecsoc_t11_n1.pdf (accessed 9 November 2015) (in Russian).

DiMaggio P., Powell W. (1983) The Iron Cage Revisited: Institutional Isomorphism and Collective Rationality in Organizational Fields. American Sociological Review, vol. 48, pp. 147-160.

Feldman M., March J. (1981) Information in Organizations as Signal and Symbol. Administrative Science Quarterly, vol. 26, no 2, pp. 171-186.

Filippov A. (2013) Sovetskaya sotsiologiya kak politseyskaya nauka [Soviet Sociology as a Police Science]. New Literary Observer, vol. 123, pp. 48-63 (in Russian).

Firsov B.M. (2001) Istoriya sovetskoy sociologii 1950-1980-hk godov [History of Soviet Sociology], St.Petersburg: Izdatel'stvo "Evropeyskiy universitet v Sankt-Peterburge” (in Russian).

Graham L. (1998) Ocherki istorii rossiyskoy i sovetskoy nauki [Essays on the History of Russian and Soviet Science], Moscow: Yanus-K (in Russian).

Guba K. (2015) Poisk i otbor rukopisey v amerikanskikh sotsiologicheskikh zhurnalakh: set' vs rynok [How Sociological Journals Select Articles: Networks vs. Market]. Sotsiologiya vlasti, vol. 3, pp. 93-125 (in Russian). 
Gudkov L., Dubin B. (1994) Literatura kak sotsial'nyy institute [Literature as Social Institute], Moscow: New Literary Observer Publishing House (in Russian).

Greenfeld L. (1988) Soviet Sociology and Sociology in the Soviet Union. Annual Review of Sociology, vol. 14, pp. 99-123.

Johnson M. (2008) Historical Legacies of Soviet Higher Education and the Transformation of Higher Education Systems in Post-Soviet Russia and Eurasia. The Worldwide Transformation of Higher Education (eds. D. P. Baker, A. W. Wiseman), Bingley, UK: Emerald Group Publishing Limited, pp. 159-176.

Kakim byt' zhurnalu [What Kind of Journal Should be SotsIs]. (1988) Sotsiologicheskie issledovaniya, vol. 3, pp. 138-142 (in Russian).

Kamens D. H. (1977) Legitimating Myths and Educational Organization: The Relationship between Organizational Ideology and Formal Structure. American Sociological Review, vol. 42, no 2, pp. 208-219.

Kon I. S. (2008) Vosem'desyat let odinochestva [Eighty Years of Loneliness], Moscow: Vremya (in Russian).

Kostenko V. V., Yakovlev G. A. (2014) Sostav avtorov zhurnala "Sotsiologicheskiye issledovaniya", 1975 1982 [The Composition of the Authors of the Journal "Sociological Studies", 1975-1982]. Sotsiologicheskiye issledovaniya, vol. 9, pp. 123-130.

Kuz'minov Y. I., Semenov D. S., Frumin I. D. (2013) Struktura vuzovskoy seti: ot sovetskogo k rossiyskomu "master-planu" [University Network Structure: From the Soviet to the Russian "Master Plan"]. Voprosy obrazovaniya, vol. 4, pp. 8-69 (in Russian).

Nauchnaya khronika [Academic Events]. (1987) Sotsiologicheskie issledovaniya [Sociological Research], vol. 1, pp. 122 (in Russian).

Meyer J., Rowan B. (1977) Institutionalized Organizations: Formal Structure as Myth and Ceremony. American Journal of Sociology, vol. 83, pp. 340-363.

Moody J. (2004) The Structure of a Social Science Collaboration Network: Disciplinary Cohesion from 1963 to 1999. American Sociological Review, vol. 69, no 2, pp. 213-238.

Moody J., Light R. (2006) A View from Above: The Evolving Sociological Landscape. American Sociologist, vol. 37, no 2, pp. 67-86.

North D. (1993) Instituty i ekonomicheskiy rost: istoricheskoe vvedenie [Institutes and Economic Growth: Historical Introduction]. THESIS, vol. 1, pp. 69-90 (in Russian).

O povyshenii roli marksistsko-leninskoy sotsiologii v reshenii uzlovykh problem sovetskogo obshchestva [On Strengthening the Role of the Marxist-Leninist Sociology in Solving Key Problems of Soviet Society]. (1988) Sotsiologicheskiye issledovaniya, vol. 5, pp. 3-5 (in Russian).

Pavlyutkin I. V.(2007) Chto mozhet skazat' novyy institutsionalizm o povedenii obrazovatel'noy organizatsii? [What can be Said about the Behavior of the New Institutionalism Educational Organization?]. Ekonomika universiteta: instituty i organizatsii [University Economics: Institutions and Organizations] (eds. M. V. Semenova), Moscow: HSE Publishing House, pp. 151-167 (in Russian). 
Pontille D. (2003) Authorship Practices and Institutional Contexts in Sociology: Elements for a Comparison of the United States and France. Science Technology Human Values, vol. 28, no 2, pp. 217-243.

Razvitie sotsiologicheskikh issledovaniy v USSR i zadachi zhurnala [The Development of Sociology in USSR and Journal Goals]. (1974) Sotsiologicheskie issledovaniya, vol. 1, pp. 3-11 (in Russian).

Shalin D. (1990) Sociology for the Glasnost Era: Institutional and Substantive Change in Recent Soviet Sociology. Social Forces, vol. 68, no 4, pp. 1019-1039.

Sokolov M. (2011) Rynki truda, stratifikatsiya i kar'ery v sovetskoy sotsiologii: Istoriya sovetskoy sotsiologicheskoy professii [Academic Marketplace, Stratification, and Career in Soviet Sociology: History of the Soviet sociologists as Profession]. Journal of Economic Sociology = Ekonomicheskaya sotsiologiya, vol. 12, no 4, pp. 37-42. Available at: http://ecsoc.hse.ru/2011-12-4/42287242.html (accessed 9 November 2015) (in Russian).

Sokolov M. (2015) Demograficheskiye i sotsial'nyye profili subdistsiplin v sovetskoy i rossiyskoy sotsiologii [Demographic and Status Profiles of Subspecialties in Soviet and Russian Sociology]. Sotsiologicheskiye issledovaniya, vol. 9, pp. 49-56 (in Russian).

Sokolov M., Volokhonskiy V. (2013) Politicheskaya ekonomiya rossiyskogo vuza [The Political Economy of the Russian University]. Otechestvennyye zapiski [Notes of the Fatherland], vol. 4, pp. 25-33 (in Russian).

Sotsiologicheskoe nasledie [Sociological Heritage] (1987). Sociologicheskie issledovaniya, vol. 5, pp. 45-55 (in Russian).

Useem M. (1976) Government Patronage of Science and Art in America. American Behavioral Scientist, vol. 19 , no 6, pp. 785-804.

Weick K. (1976) Educational Organizations as Loosely Coupled Systems. Administrative Science Quarterly, vol. 21, no 1, pp. 1-19.

Weinberg E. (2004) Sociology in the Soviet Union and Beyond. Sociology, vol. 14, pp. 99-112.

Yurchak A. (2014) Eto bylo navsegda, poka ne konchilos'. Posledneye sovetskoye pokoleniye. [It was Forever until It was Over. The Last Soviet Generation], Moscow: New Literary Observer Publishing House (in Russian).

Zucker L. G. (1987) Institutional Theories of Organization. Annual Review of Sociology, vol. 13, pp. 443464.

Zuckerman E. (1999) The Categorical Imperative: Securities Analysts and the Illegitimacy Discount. American Journal of Sociology, vol. 104, no 5, pp. 1398-1438.

Received: May 12, 2015.

Citation: Guba K. (2015) Izdavaya "SotsIs", ili Problema legitimsnosti v sovetskoy sotsiologii [Editing the Soviet Sociological Journal: The Problem of Legitimacy in Soviet Sociology]. Journal of Economic Sociology = Ekonomicheskaya sotsiologiya, vol. 16, no 5, pp. 20-45. Available at http://ecsoc.hse.ru/2015-16-5.html (in Russian). 


\section{ДЕБЮТНЫЕ РАБОТЫ}

\section{А. А. Долгова, Е. С. Митрофанова \\ Отделение от родительской семьи в России: межпоколенческий аспект}

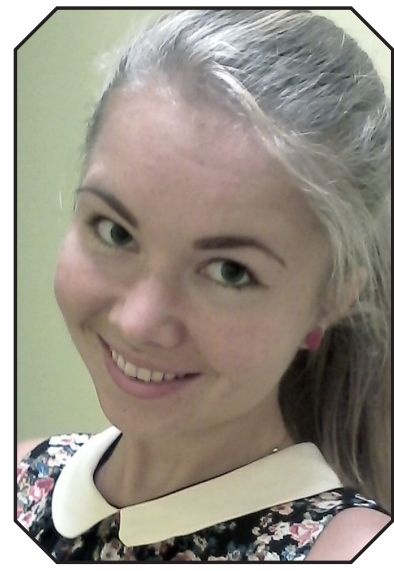

ДОЛГОВА Алина Александровна лаборант Лаборатории экономикосоциологических исследований НИУ ВШЭ. Адрес: Россия, 101000, г. Москва, ул. Мясницкая, д. 20.

\section{Email: aadolgova24@} gmail.com
Отделение от родителей - знаковое и значимое событие в жизни человека, ассоииирующееся с независимостью, самостоятельностью, взрослостью. Это начало нового, важного этапа жизни, часто связанного с созданием собственной семьи, выходом на рынок труда. Находясь в связке с демографическими и сочиоэкономическими событиями, покидание родительского дома представляет интерес как для демографии, так для соичологии и экономики.

В условиях Второго демографического перехода наблюдаются увеличение периода получения образования, рост карьерных притязаний, желание самоутверждения в молодые годы и откладывание брака и деторождения на более поздний срок. Данные проиессы влияют на модель отделения от родительской семьи. Как и в каком возрасте современная молодёжь, если сравнивать её с более старшими поколениями, покидает родительский дом? От каких факторов зависит тот возраст, в котором дети начинают жить отдельно от родителей? На эти и другие вопросы мы ответим с помощью репрезентативных данных трёх волн обследования «Родители и дети, мужчины и женщины в семье и обществе» (РиДМиЖ, 2004, 2007, 2011 22.).

Методы анализа наступления событий (event history analysis), а именно таблицы жизни (Life Tables) и регрессии Кокса (Cox regression), позволили нам выявить, что межпоколенческое единообразие поведения при начале проживания отдельно от родителей нарушается (молодёжь теперь отделяется позже, чем это происходило раньше, у более старших поколений), а внутри каждого поколения покидание родительского дома обусловлено различными сопутствующими событиями - получением образования, выходом на рынок труда, началом сожительства с партнёром или регистраичией брака.

1 Исследование выполнено в рамках проекта № 14-05-0055 «Изучение динамики формирования и развития семей и процессов рождаемости на данных выборочных обследований» по конкурсу исследовательских проектов научно-учебных групп Программы «Научный фонд НИУ ВШЭ».

Авторы статьи признательны за помощь в подготовке данного исследования руководителю научно-учебной группы НИУ ВШЭ «Изучение рождаемости, формирования, развития и распада семей на данных выборочных обследований» С. В. Захарову, а также Д. Х. Ибрагимовой и коллективу Лаборатории экономико-социологических исследований (ЛЭСИ) НИУ ВШЭ за предварительное обсуждение версии статьи на одном из семинаров лаборатории и чуткое руководство на всех этапах работы. 


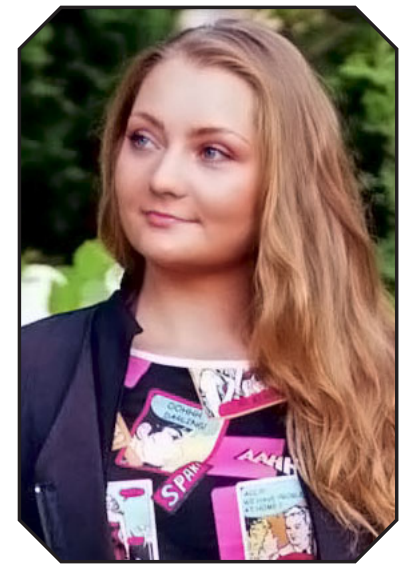

МИТРОФАНОВА Екатерина Сергеевна младший научный сотрудник Лаборатории социальнодемографической политики, преподаватель Института демографии НИУ ВШЭ. Адрес: Россия, 101000, г. Москва, ул. Мясницкая, д. 20.

\section{Email: mitrofanovy@} yandex.ru
Ключевые слова: отделение от родительской семьи; жизненный путь; социально-демографическое поведение; межпоколенческие различия; поколения; анализ наступления событий.

\section{Введение}

Отделение от родителей является популярной темой современных исследований. Покидание родительского дома в европейских странах и США рассматривается как очень значимое событие в жизненном пути индивида, связанное с переходом во взрослую жизнь [Блоссфельд, Хъюнинк 2006; Блюм, Себий, Захаров 2010; Buck, Scott 1993; Billari, Philipo, Baizán 2001; Corijn, Klijzing 2001; Fukuda 2009; Evans 2013]. Перспектива отделения от родителей тесно связана с образовательными и карьерными возможностями, институциональными особенностями общества, наличием жилья на рынке и его ценой [Mitchell 2000], типом семьи, силой межродственных связей внутри неё, обладанием финансовых ресурсов и с индивидуальными особенностями человека [Fukuda 2009]. В современных обществах причины перехода к отдельному проживанию от родителей уже в меньшей степени связаны с созданием собственной семьи [Van de Каa 1987]. Традиционная модель покидания родительского дома, когда проживание отдельно от родителей стимулировалось регистрацией брака, сменяется модернизированными видами поведения, когда отъезд из дома родителей объясняется как образовательной, трудовой мобильностью, так и сожительством с партнёром [Вишневский 2006].

Возраст отделения от родителей и причины отделения различаются от страны к стране [Billari, Philipov, Baizán 2001]. До начала 1970-х гг. в странах Европы возраст отделения от родителей не превышал 20 лет. После 1970-х в Германии, Франции, Италии, Англии, Дании начал расти возраст вступления в брак [Furlong 2009], в связи с чем модели поведения при отделении от родителей в разных странах стали различаться. В Северной и Западной Европе, где распространён более индивидуалистический тип поведения, отделение от родителей в большей степени связано с построением карьеры и самореализацией. В странах Южной и Центральной Европы сохраняется традиционная модель, где отделение от родителей по-прежнему связано с регистрацией брака [Billari, Philipov, Baizán 2001]. Межпоколенческое единообразие поведения при начале проживания отдельно от родителей нарушается [Fussell 2002: 42]. Данные изменения свидетельствуют об усложнении процесса отделения от родителей.

Покидание родительского дома в России - тема, вызывающая особый интерес. Он обусловлен тем, что изменения, произошедшие в экономической, социальной, политической структурах общества после распада СССР, не могли не сказаться на особенностях наступления основных демографических и социоэкономических событий [Беляева 2004: 32]. Новый этап общественного развития, который в странах Запада начался в середине 1960-х гг., в России стал проявляться на два десятилетия позже, а то и более, то есть относительно недавно [Захаров 2002]. Эти тенденции подробно описаны исследователями (см.: [Долбик-Воробей 2003; Магун, Энговатов 2005; Виш- 
невский 2006; Захаров 2007; Попова 2009; Блюм, Себий, Захаров 2010; Чернова, Шпаковская 2010; Захаров, Митрофанова 2014; Тындик, Митрофанова 2014]). В России возраст вступления в брак, как и в странах Европы, повышается: с 20 лет в 1930 г. до 26 лет в 2000 г. [Захаров 2006]. Снижается доля состоящих в браке к возрасту 35 лет: с 90\% в поколении 1965-1969 гг. до 75\% в поколении 1975-1979 гг. [Захаров 2007]. Растёт и число не зарегистрированных в ЗАГСе отношений [Захаров 2007: 102]. Период получения образования увеличивается, а доля занятых на рынке труда в возрасте 20-25 лет сокращается [Вишневский 2006: 68; Константиновский 2014: 283].

В связи с изменениями, которые мы можем наблюдать в российском обществе, возникает вопрос: как указанные выше процессы влияют на модель отделения от родительской семьи в России? В данной работе мы отвечаем на главный исследовательский вопрос о том, будет ли различаться модель отделения от родительской семьи для разных поколений России, и если да, то каким образом.

Изучение данного вопроса представляет, на наш взгляд, интерес с нескольких позиций. Во-первых, с точки зрения понимания общей динамики изменений, которые происходят в социально-демографическом поведении россиян в условиях Второго демографического перехода. Предположение о значимости эффекта поколения позволяет допустить, что, например, для людей, чьё взросление пришлось на послеперестроечное время, более экономически ресурсное и свободное, отделение от родителей будет во многом связано с выходом на рынок труда или с окончанием образования. Рассматривая четыре временны́х периода (околовоенный${ }^{2}$, доперестроечный, перестроечный и послеперестроечный), мы предполагаем, что институциональные условия социализации для каждого поколения обусловливали связь отделения с определённым сопутствующим событием - с завершением получения образования, выходом на рынок труда, началом сожительства с партнёром и регистрацией брака [Elder 1985; Ежов 2005].

Во-вторых, исследование межпоколенческих различий в возрасте отделения от родителей и факторов, на него влияющих, способно обогатить имеющиеся знания о взрослении и процессе покидания родительского дома в России. В настоящей работе мы предполагаем, что в России, как и во многих странах Запада, на фоне значимых демографических, экономических и социальных трансформаций условия жизни человека и новые возможности способствуют смене социально-демографического поведения. Например, размер семьи мог по-разному оказывать влияние на время отделения от родителей: в доперестроечный период возможность отдельного проживания была сильно ограничена нехваткой дополнительного жилья, существовали сильные межродственные связи и, как следствие, размер семьи мог не влиять на начало проживания отдельно от родителей; в послеперестроечное время существует больше возможностей для переезда в отдельное домохозяйство: развит строительный рынок, существуют услуги по аренде жилья, поэтому размер семьи мог стать одним из факторов, способствующих более раннему отделению от родителей.

Результаты данного исследования носят ознакомительный характер и показывают, какие межпоколенческие различия существуют при отделении от родительской семьи, как их стоит изучать в дальнейшем. В статье несколько частей: сначала сделан краткий обзор теоретических и эмпирических подходов к исследованию отделения от родителей и к изучению межпоколенческих различий; затем представлены методология и эмпирическая база, то есть описана концептуальная модель настоящего исследования. Далее с помощью регрессионного анализа мы анализируем вероятность отделения от родителей для представителей каждого поколения в возрастном интервале 15-35 лет, выявляем роль социально-демографических факторов при отделении от родителей. В завершение работы представлены основные результаты исследования и сделан вывод о межпоколенческих различиях во времени отделения от родителей и факторах, влияющих на начало проживания отдельно от родителей.

2 Имеется в виду Великая Отечественная война (1941-1945 гг.). 


\section{Обзор теоретических подходов}

\section{Отделение от родителей в условиях Второго демографрического перехода}

Д. Ван де Каа указывает на три основных сдвига в сфере воспроизводства, обусловленных Вторым демографическим переходом [Van de Kaа 1987]: (1) изменение во времени создания семьи и в прочности брачных уз; (2) изменение контрацептивного поведения; (3) существенное снижение уровня рождаемости. Эти трансформации приводят к изменениям в календаре социодемографических событий, так как и у мужчин, и особенно у женщин появляется возможность инвестировать ресурсное время молодости не в рождение и воспитание детей, а в свой человеческий капитал. Речь идёт не о нивелировании ценности деторождения и семьи, а об откладывании этих событий до того времени, пока человек не станет готов к ним психологически и материально.

Если ранее ведущей причиной отделения от родителей выступало создание собственной семьи [Fukuda 2009: 375; Furlong 2009: 33; Mulder 2009: 205], то в условиях откладывания демографических событий в качестве выталкивающей силы стали выступать завершение получения образования, выход на рынок труда и начало совместного проживания с партнёром. Этот процесс можно наблюдать в странах, где произошёл Второй демографический переход, в том числе в Великобритании, Скандинавии, Северной Америке, Германии и Австрии [Blossfeld 1986; Aassve et al. 2001; Billari, Philipov, Baizán 2001; Corijn, Klijzing 2001]. В странах с более традиционным демографическим поведением (Греция, Италия, Испания) начиная с 1960-х гг. также стал расти возраст вступления в брак, но из-за более тесных внутрисемейных связей это повлияло лишь на увеличение времени проживания детей в родительском доме [Cordon 1997; Reher 1998; Lesthaeghe, Moors 2000; Aassve et al. 2001; Billari, Philipov, Baizan 2001; Corijn, Klijzing 2001].

Причины раннего отделения от родителей в США и Северной Европе обусловлены более индивидуалистическим типом поведения. Чтобы достичь максимального конкурентного преимущества на рынке труда и обрести финансовую независимость, необходимо получить соответствующее образование, что требует времени [Iacovou, Skew 2010]. Часто отделение от родителей в странах Европы происходит до окончания получения высшего образования, что связано с образовательной мобильностью, которая в большей степени популярна в странах Северной Европы, например, в Швеции и Великобритании, где 55\% молодых людей и $72 \%$ девушек уезжают от родителей в связи с учёбой [Billari, Philipov, Baizán 2001].

Подробную классификацию причин отделения от родителей в странах Европы представили Ф. Биллари и его коллеги в исследовании «Leaving Home in Europe: The Experience of Cohorts Born in 1960» («Покидание родительского дома в Европе: опыт представителей когорт 1960-х гг. p.»³) [Billari, Philipov, Baizán 2001]. Исследователи выделили следующие модели отделения от родителей: «средиземноморская», которая связана с заключением брака; «северная», осуществляемая одновременно с выходом на рынок труда; «британская», зависящая от поступления в университет, поскольку в Англии очень развита практика обучения в университетах-кампусах. В большинстве из рассмотренных в исследовании Ф. Биллари стран существуют различные взгляды на то, когда должно происходить отделение от родителей и в связи с какими событиями. Однако в целом современная молодёжь покидает родительский дом гораздо позже, чем это делали их родители [Кnijn 2012: 106]. В среднем респонденты, рождённые в 1970-1979-х гг., после окончания учёбы покидали родителей позднее, чем те, кто ро-

3 Выборочную совокупность исследования составили мужчины и женщины 1956-1965 гг. р. из следующих европейских стран: Австрии, Бельгии, Чешской Республики, Восточной Германии, Финляндии, Франции, Венгрии, Италии, Латвии, Литвы, Нидерландов, Норвегии, Польши, Португалии, Словении, Испании, Швеции, Швейцарии, Великобритании, Западной Германии. 
дился в 1960-х гг.; при этом женщины начинали жить отдельно на два года раньше мужчин [Iacovou, Skew 2010]. Важной причиной позднего отделения от родителей в странах Южной Европы является ценность большой многопоколенческой семьи и помощь родственников друг другу, чего нельзя сказать о Северной Европе, где нуклеарная семья вытеснила традиционный тип родственных отношений [Reher 1998]. В связи с этим тип семьи во многом оказывает влияние на то, когда происходит отделение от родителей. Таким образом, отделение от родителей зависит от культурно-исторических особенностей страны, системы образования, ситуации на рынке труда, модели матримониального поведения [Lesthaeghe, Moors 2000].

Говоря о специфике Второго демографического перехода в России, стоит заметить, что он начался на 20-30 лет позже, чем в странах Европы. На протяжении долгого периода для российского общества была характерна ранняя брачность, и создание семьи происходило преимущественно до 25 лет. Но, как отмечает А. Г. Вишневский, изменения, которые произошли на Западе (индивидуализация, ориентация на карьеру и самореализацию, расширение свободы выбора и откладывание брака на поздний срок), в последние десятилетия наблюдаются и в России [Вишневский 2006: 137]. Проанализировав время отделения от родительской семьи в разных странах и связь такого решения с различными социально-демографическими событиями в жизни человека, А. Г. Вишневский отметил, что выход из родительского дома во многом зависит от степени индустриализации страны и индивидуализации жизни её граждан. Если расположить страны по времени выхода из родительской семьи и степени индустриализации, то первыми идут страны Северной Европы, в том числе Скандинавского полуострова, и Западной Европы, затем страны Южной Европы, где всё ещё сохраняется традиция проживания в родительском доме до брака; самую низшую ступень классификации занимают страны Восточной и Центральной Европы [Вишневский 2006: 143]. Из-за того что демографическое поведение россиян стало модернизироваться на несколько десятилетий позже, мы предполагаем, что Россия пока ещё принадлежит к последней группе стран в данной классификации.

\section{Отделение от родителей как событие жизненного пути}

Одной из важных теоретических рамок данной работы, помимо теории Второго демографического перехода, является концепция жизненного пути, уже много лет успешно развиваемая зарубежными социологами и демографами [Elder 1985; Mitchell 2000; Furlong 2009].

Концептуально жизненный путь - это последовательность состояний, переходов, создаваемая индивидом в ходе его жизни [Блоссфельд, Хъюнинк 2006: 17], «последовательность действий и событий в различных сферах жизни и в институционализированных полях деятельности» [Митрофанова 2011: 527]. Жизненный путь представляет собой комплексный процесс, поскольку на него влияет как сам человек, исходящий из своего личного опыта и взглядов, так и социокультурное, историческое пространство.

Большое внимание в концепции жизненного пути уделяется процессу перехода индивида во взрослую жизнь (transition to adulthood) [Furstenberg 2010]. Общая тенденция для развитых стран такова, что календарь наступления событий в жизни человека сдвигается. Об этом начиная с 1980-х гг. писал Дж. Арнетт, который ввёл термин emerging adulthood, то есть «длящееся взросление». Данный этап в жизни человека следует за подростковым периодом и предшествует обретению статуса взрослого [Arnett 2000: 469]. Важнейшими событиями этого этапа жизни являются (1) получение образования, (2) трудоустройство, (3) сожительство с партнёром, (4) регистрация брака, (5) отделение от родителей, (6) рождение ребёнка [Elder 1985; Блюм, Себий, Захаров 2010; Тындик, Митрофанова 2014]. В рамках данного исследования мы сосредоточимся на влиянии первых четырёх событий на начало проживания отдельно от родителей. Рождение ребёнка не рассматривается, поскольку может быть реализовано до- 
статочно поздно и в меньшей степени склонно оказывать влияние на переезд из родительского дома [Блоссфельд, Хъюнинк 2006: 18].

Проживание отдельно от родителей может как способствовать наступлению других событий в жизни человека (отделение выступает «донором»), так и стимулироваться их наступлением (отделение выступает «реципиентом»). Донорскую сущность переезд от родителей проявляет, когда наступление этого события даёт старт, например, получению образования или выходу на рынок труда. Отделенияреципиенты, напротив, происходят благодаря другим событиям, например, устроившись на работу и получив экономическую независимость, либо выйдя замуж (женившись), индивид получает возможность переехать от родителей.

При отделении от родителей индивид приобретает не только территориальную, но финансовую и психологическую автономность [Mitchell 2000]. При этом физическая автономность не всегда означает полную независимость от родительского контроля, поскольку родители могут влиять на своих детей, поддерживать их материально, даже если проживают отдельно. Наличие психологической автономности может являться следствием сильных или слабых связей внутри семьи, близости общения. Три типа автономий от родительской семьи, которые индивид приобретает в результате отдельного проживания, говорят о том, что на данное событие может влиять большое количество факторов, в том числе структура общества, принятые нормы, а также индивидуальные особенности человека [Mitchell 2000; Mulder 2009].

Отделение от родителей, как и все события в жизненном календаре индивида, зависит от исторического периода и социальных условий, которые различаются для представителей разных когорт [Ryder 1965]. Для того чтобы определить, как индивидуальные и структурные процессы взаимодействуют между собой и влияют на начало проживания отдельно от родителей, стоит также рассмотреть теорию поколений К. Мангейма [Mannheim 1952] и варианты её применения к российской действительности.

\section{Межпоколенческий аспект начала проживания отдельно от родителей}

Каждое событие жизненного пути несёт след тройственности времени в демографии, аккумулируя эффекты возраста, периода и когорты [Shorrocks 1975]. В данном исследовании влияние периода носит латентный характер, так как мы рассматриваем этап взросления, который у разных поколений проходил в разное историческое время, но переменных для контроля эпохи (то есть макропоказателей политического, социального, экономического уровней) у нас нет. Влияние возраста при изучении событий, входящих в круг наших интересов, практически отсутствует, поскольку отделения от родителей у индивидов происходят примерно в одном возрастном промежутке. Сильнее всего в данном исследовании проявляется эффект когорты, который мы расширим до межпоколенческого и латентно учитывающего эффект периода (культурно-исторический контекст).

Термин «поколение» шире, чем понятие «когорта». Когорта (демографическое понятие) - это совокупность индивидов, которые родились в один год. Поколение (социологическая интерпретация понятия «когорта») - группа людей, родившихся в одном временном периоде, прошедших социализацию в одном историческом периоде, имеющих схожее мировосприятие и поведение. В отечественной литературе нет единства в операционализации термина «когорта» [Беляева 2004]. Понятие «поколение» - это настраиваемый инструмент. В зависимости от задач и сферы приложения, границы и длина (шаг) поколения могут быть самыми разными: если мы рассматриваем поколение применительно к воспроизводственному поведению, уместно взять интервал, равный среднему возрасту матери при рождении ребёнка; если нас интересует социокультурная перспектива, шаг будут задавать важные исторические события [Левада 2005: 41-44]; если социопсихологическая - периоды социализации 
(примерно 15 лет) [Шанин 2005: 20]. Наше исследование лежит в социодемографической плоскости, поэтому необходима классификация, учитывающая влияние исторических условий в период социализации индивидов.

Обратимся к классификации В. В. Семёновой, в которой поколения россиян сгруппированы на основе схожести условий социализации и собственной интерпретации индивидами своих жизненных историй [Семёнова 2005]. Были выделены четыре поколения:

— «околовоенное» поколение (годы рождения: 1920-1940; годы социализации: 1940-1960). Это люди, социализация и взросление которых проходили в послевоенные годы. Они принимали активное участие в восстановлении народного хозяйства страны после войны, повышении её промышленного уровня. Представители этой группы перенесли тяготы военного времени, что не могло не отразиться на событиях в их жизни. «Важной составляющей на протяжении всей жизни для них является трудовая культура, для них труд - образ жизни» [Семёнова 2005: 92]. При этом характер труда был малоквалифицированный, индустриальный. Высшее образование имело малую значимость. Нравственным считался только зарегистрированный брак; отношения вне брака порицались. В 1944 г. усложнилась процедура развода, поэтому браки расторгались реже, а институт семьи в большой степени контролировался государством;

- «доперестроечное» поколение (годы рождения: 1940-1960; годы социализации: 1960-1980). Эпоха «бэби-бума» и романтизации любовных отношений. Регистрация брака, как и в предыдущем периоде, официально оформляла сексуальные отношения, которые порицались вне семьи. У представителей данной группы сильно выражена тяга к учёбе и новым открытиям. Стаж, возраст, опыт во многом определяли материальное благополучие в советских поколениях. Действовал кумулятивный эффект повышения жизненного уровня [Беляева 2004], поэтому экономические ресурсы в основном концентрировались вокруг старших возрастных групп, которые поддерживали молодёжь до того момента, пока она не накопит нужный «капитал»: плановая экономика не давала возможности добиться сразу высокого дохода для молодых, так как он не зависел от интенсивности труда [Семёнова 2005];

- поколение «переходного» периода (годы рождения: 1960-1970; годы социализации: 1990-е). Для этих людей характерен «синдром ностальгии по прошлому» [Семёнова 2005: 100]. Ориентация на образование уже не такая высокая, но при этом заметна более активная позиция в области рыночных отношений и труда, которые приходили на смену советской плановой экономике. Новые рыночные возможности быстрее улавливаются молодыми, они становятся активнее на рынке труда, но при этом ориентируются на «быстрые деньги». Происходит демократизация интимных отношений, средства контрацепции разделяют сексуальное, брачное и репродуктивное поведения, общество становится более терпимым к добрачным связям. Поведение во всех сферах жизни становится более индивидуалистичным;

— «nослеперестроечное» поколение (годы рождения: 1980-е; годы социализации: 2000-е). Это представители времени модернизации общества, открытия его границ, увеличения возможностей и свобод. Качественное образование в новых условиях становится для нового поколения самоцелью. Однако молодые люди не спешат начинать трудовую деятельность, а хотят посвятить время собственному развитию, получению удовольствия от жизни и поиску себя. Это «поколение прагматиков, лишённых социальной памяти, свободное от идеологических ограничений» [Левада 2005: 59]. Появляется свобода в сфере интимных отношений, что увеличивает долю сожительств по сравнению с предыдущими периодами. Доступная контрацепция позволяет регулировать наступление репродуктивных событий в жизни и лучше плани- 
ровать будущее. Образование, работа, брак - эти события начинают конкурировать между собой в зависимости от того, какое из них является более значимым в определённый момент времени.

Приведённая классификация даёт представление о ключевых ценностях поколений и их поведении в демографической и социоэкономической сферах. Поскольку в выборочной совокупности настоящего исследования поколенческий ряд представлен не столь широко (1930-1986 гг. р.), мы сформируем поколенческие группы по году рождения самостоятельно, сохранив при этом общую логику классификации Семёновой, в основе которой лежит схожесть условий социализации представителей одного временного периода. Из имеющейся выборки под наблюдение попали четыре поколения 1930-1986 гг. рождения (см. табл. 1).

Таблица 1

Поколения в выборке, $N=\mathbf{5 4 5 1}$

\begin{tabular}{|c|c|c|c|}
\hline Классификация В. В. Семёновой & \multicolumn{3}{|c|}{ Классификация в настоящем исследовании } \\
\hline Поколения & Годы рождения & Годы социализации & Численность, \% \\
\hline $\begin{array}{l}\text { «Околовоенное» (годы рождения: } \\
\text { 1920-1940; годы социализации: } \\
\text { 1940-1960) }\end{array}$ & $1930-1944$ & $1945-1959$ & 21 \\
\hline $\begin{array}{l}\text { «Доперестроечное» (годы рожде- } \\
\text { ния: 1940-1960; годы социализации: } \\
\text { 1960-1980) }\end{array}$ & $1945-1959$ & $1960-1974$ & 32 \\
\hline $\begin{array}{l}\text { «ерестроечное» (годы рожде- } \\
\text { ния: 1960-1970; годы социализации: } \\
\text { 1980-1990) }\end{array}$ & $1960-1974$ & $1975-1989$ & 32 \\
\hline $\begin{array}{l}\text { «Послеперестроечное» (годы рождения: } \\
\text { 1980-е; годы социализации: 2000-е) }\end{array}$ & $1975-1986$ & 1990-2005 & 15 \\
\hline
\end{tabular}

\section{Основные задачи и гипотезы исследования}

Наш главный тезис заключается в том, что возраст отделения от родителей подвержен влиянию как социально-демографических характеристик индивида, так и институциональных условий, в которых проходит социализация представителя каждого поколения.

В рамках настоящей работы предполагается решить следующие задачи:

- определить момент времени, когда вероятность отделения от родителей наиболее высока в каждом поколении;

— определить, с какими событиями связано отделение от родителей;

- определить факторы, повышающие вероятность отделения от родителей для каждого поколения.

Для конкретизации поставленных задач мы выдвинем ряд гипотез и опишем предполагаемые эффекты воздействия потенциальных факторов, которые нам удалось выделить на основе вышеизложенных теоретических подходов и проанализированных эмпирических исследований по заданной теме.

Гипотеза 1 (Г 1). Вероятность отделения от родителей для самого молодого поколения в выборке - «послеперестроечного» (1975-1986 г2. р.) - будет ниже, чем для других поколенческих групп. 
О том, что вероятность отделения от родителей в разрезе поколений уменьшается, свидетельствуют многие зарубежные исследования [Billari, Philipov, Baizán 2001; Iacovou, Skew 2010; Knijn 2012]. Tак как в России отмечаются тенденции, характерные для Второго демографического перехода, есть основания предполагать, что и в нашей стране можно наблюдать снижение вероятности отделения от родителей в молодых возрастах по мере приближения к самому молодому поколению в выборке - «послеперестроечному» (1975-1986 г2. р.).

Гипотеза 2 (Г 2). Во всех поколенческих группах женщины начинают жить отдельно от родителей раньше, чем мужчинь.

Существуют значительные гендерные различия в том, когда происходит отделение от родителей: во многих странах женщины начинают жить отдельно на один-два года раньше мужчин [Buck, Scott 1993; Billari, Liefbroer 2007]. Это во многом объясняется тем, что женщины чаще покидают родительский дом в связи с браком, регистрация которого происходит также в более раннем возрасте, чем у мужчин. Поскольку изменения в демографическом поведении россиян начали происходить позже, чем в странах Европы, этот дисбаланс может сохраниться во всех поколениях.

Гипотеза 3 (Г 3). Проживание в мегаполисе до 15 лет (Москва, Санкт-Петербург) способствует более позднему отделению от родителей.

Небольшие города, сёла имеют ограниченные возможности для обучения и трудоустройства [Zorlu, Mulder 2011], поэтому определённая часть их жителей будет покидать родительский дом в связи с трудовой и образовательной мобильностью. Также для небольших, сельских, населённых пунктов характерно более традиционное демографическое поведение, что также может способствовать раннему отделению от родительской семьи.

Гипотеза 4 (Г 4). Наличие братьев и сестёр способствует более раннему отделению от родителей в постсоветских поколениях.

В исследовании о начале отдельного проживания в Японии, где, как и в России, существуют крепкие межродственные связи, было зафиксировано, что в поколениях до 1960-х гг. число сибилингов (братьев, сестёр) никак не влияло на время отделения от родителей. А в настоящее время вероятность отделиться от родителей тем выше, чем больше размер семьи [Buck, Scott 1993; Mitchell 2000; Fukuda 2009].

Гипотеза 5 (Г 5). Для представителей «околовоенного» (1930-1944 г2. р.) и «перестроечного» (1960-1974 г2. р.) поколений отделение от родителей в большей степени связано с выходом на рынок труда.

Два разных поколения, начинавших трудовую деятельность в разных условиях, схожи в довольно раннем и активном начале работы. В первом случае («околовоенное» поколение) это объясняется политикой государства по индустриализации страны и общей трудовой мобилизацией в послевоенное время, во втором («перестроечное» поколение) — новыми рыночными условиями и желанием заработать «быстрые деньги» [Семёнова 2005].

Гипотеза 6 (Г 6). Для представителей «доперестроечного» поколения (1945-1959 г2. p.) отделение от родительской семьи происходит в связи с регистраџией брака.

Связанность матримониального, репродуктивного и сексуального поведения в советское время [Вишневский 2006: 73; Митрофанова 2011], а также возможность получения жилья при рождении ребёнка делали демографические события главным катализатором отделения индивидов от родителей. 
Гипотеза 7 (Г 7). Для представителей «послеперестроечного» поколения (1975-1986 г2. p.) отделение от родительской семьи в большей степени связано с сожительством с партнёром, чем в других группах.

Всё более популярными тенденциями среди молодёжи становятся распространение незарегистрированных отношений как альтернативы официальному вступлению в брак и более поздние браки [Гурко, Игнатова 1997: 51; Козырева, Лежнина 2014: 192]. Регистрация брака в России откладывается на более поздний срок и всё чаще заменяется сожительством [Долбик-Воробей 2003; Вишневский 2006: 141; Захаров 2007: 75-112]. Сожительство, являющееся пробой брака или его альтернативой, часто подразумевает переезд от родителей в своё либо в съёмное жильё. Это новая для России тенденция, которой не было в предыдущих поколениях вследствие порицания добрачных и внебрачных отношений.

\section{Информационная база исследования, измерение и методы анализа}

\section{База данных}

В качестве эмпирического материала для анализа использовались панельные данные трёх волн обследования «Родители и дети, мужчины и женщины в семье и обществе» (РиДМиЖ), которое было проведено Независимым институтом социальной политики в России в 2004, 2007, 2011 гг. РиДМиЖпервое российское исследование, которое позволяет проанализировать последовательность наступления социально-демографических событий в жизни человека и отдельных групп [Захаров 2007: 105]. «Обследование РиДМиЖ входит в программу “Поколение и гендер”, которая, в свою очередь, является частью европейского исследования, проходившего в 20 странах Европы с целью выявления изменений и новых тенденций в социальной и демографической сферах» [Синявская, Тындик 2009: 14]. «Выборочная совокупность в обследовании является в полной мере репрезентативной с точки зрения структуры населения России, и она не была стратифицирована по возрастным группам» [Головляницина, Синявская 2009: 331-333].

Из объединённого массива трёх волн использовались панельные данные по состоянию на 2011 г. Объём выборки - 5451 человек. Гендерное распределение в выборке оказалось смещённым: 32\% мужчин и 68\% женщин. Поскольку мы работаем с панельными данными, то не можем провести процедуру корректировки выборки, так как имеются лишь веса для каждой волны в отдельности.

\section{Концептуализация, операционализация основных понятий и ограничения исследования}

Начало отдельного проживания от родителей изучается в рамках теории жизненного пути (life course) и взросления (transition to adulthood) [Furstenberg 2010]. Отделение от родителей является ключевым при исследовании начала самостоятельной жизни молодыми людьми [Mitchell 2000; Goossens 2001; Fussell 2002]. Возникает вопрос: что стоит понимать под началом самостоятельной жизни, и в какой мере отделение от родителей может служить индикатором начала самостоятельной жизни?

Отделение от родителей заключает три вида автономии - территориальную, материальную и психологическую, с обретением которых можно говорить о начале самостоятельной жизни индивидом [Mitchell 2000]. Территориальная автономия подразумевает физический переезд от родителей в отдельное домохозяйство; материальное отделение означает финансовую независимость, то есть полное самообеспечение; психологическое отделение - ослабление эмоциональной, психологической зависимости от родителей. В совокупности три вида отделения способны служить маркером начала самостоятельной жизни индивидом. Зачастую наступление трёх видов автономий не происходит одно- 
временно: (1) физическое отделение от родителей может быть реализовано при полной материальной и психологической зависимости от них, например, если причина отделения - образовательная мобильность; (2) психологическая, или эмоциональная, автономия не всегда наступает после физического отделения от родителей, поскольку межсемейные крепкие связи и контакты во многом оказывают воздействие на поведение молодых людей; (3) материальное отделение может быть реализовано, несмотря на проживание в домохозяйстве родителей. Различные комбинации наступления отделения от родителей существенно осложняют процесс его изучения. Несмотря на «многоликость» отделения от родителей как события в жизни человека, под отделением в теории жизненного пути стоит понимать именно физическую автономию от родителей, то есть начало проживания в отдельном домохозяйстве [Buck, Scott 1993; Mitchell 2000; Aassve et al. 2001; Billari, Philipov, Baizán 2001]. Физическое отделение от родителей - первый шаг на пути становления личности и начала самостоятельной жизни отдельно от родителей, несмотря, например, на финансовую зависимость от них. Для содержательной интерпретации отделения, то есть объяснения причин его наступления, изучение данного события проводится вместе с уже отмеченными ранее событиями: получение образования, выход на рынок труда, начало сожительства с партнёром и регистрация брака [Elder 1985; Mitchell 2000; Mulder 2009]. Их наступление оказывает непосредственное влияние на вероятность начала отдельной от родителей жизни и служит объяснением физического отделения от родителей.

Данная работа не претендует на комплексное изучение всего периода взросления индивида, то есть всех трёх видов отделения от родительской семьи. В силу существования вышеизложенных особенностей при изучении отделения от родителей и ограниченности используемых данных мы будем уделять внимание именно территориальному аспекту отделения от родительской семьи, поскольку знаем точную дату наступления данного события, тогда как факты обретения финансовой и психологической независимости установить в данном случае не представляется возможным. Факт отделения от родителей будет фиксироваться при условии проживания индивида в другом домохозяйстве не меньше трёх месяцев подряд, так как вопрос в анкете РиДМиЖ подразумевал именно такие временные границы. При этом мы будем отслеживать только факт первичного отделения от родителей, поскольку информация о возвращении в дом родителей и повторных отделениях в анкете обследования отсутствует. Нет информации о том, в каком именно домохозяйстве - в собственном, других родственников, совместном с партнёром - стал жить респондент, не представляется возможным отследить и характер отделения (принудительное или добровольное). Более того, ограничены уровни изучения проблемы: мы располагаем только информацией о датах наступления событий, рядом сведений о родительской семье и индивидуальных характеристиках респондентов. В анкете присутствуют вопросы о ценностнонормативных ориентациях, но использовать их в данной работе некорректно, так как они отражают позицию человека на момент проведения опроса, а не на момент отделения от родителей.

Чтобы уравнять шансы разных поколений на отделение от родителей, мы ограничили возраст отделения рамками 15-35 лет. Нижняя возрастная граница была выбрана в связи с тем, что в настоящее время граждане России в 14 лет получают паспорта, имеют право официально трудоустроиться и даже заключить брак в ряде исключительных случаев. К возрасту 15 лет молодые люди могут получить среднее профессиональное образование и трудоустроиться по специальности. Психологическое взросление, связанное с появлением всех этих возможностей в жизни индивида, способно дать толчок желанию физической автономии от родителей, поэтому в качестве нижней границы мы берём 15-летие как возраст, начиная с которого молодые люди фактически готовы к самостоятельной жизни в условиях нашей страны. Верхняя возрастная граница была выбрана на основе предыдущих эмпирических исследований отделения от родителей [Billari, Liefbroer 2007; Fukuda 2009], а также исходя из структуры выборочной совокупности и распределения возрастов наступления ключевых событий. 
Поскольку в работе используется информация о наступлении сопутствующих событий в жизненном пути для представителя каждого поколения (завершение получения образования, выход на рынок труда, начало сожительства с партнёром и регистрация брака), возраст наступления данных событий мы также ограничили интервалом в 15-35 лет. Под завершением получения образования понимается любой уровень образования, являющийся для конкретного респондента наивысшим. В качестве первой работы подразумевается первая оплачиваемая занятость сроком не менее трёх месяцев. Под сожительством - совместное проживание с партнёром без регистрации отношений в ЗАГСе.

\section{Методы исследования}

Для решения каждой задачи исследования используется свой арсенал методов.

В рамках решения первой задачи (определить, в каком возрасте вероятность отделения от родителей наиболее высока в каждом поколении) были построены таблицы жизни. Таблица жизни (смертности, выбытия) - это математическая модель, характеризующая порядок выбытия индивидов из-под наблюдения. Она показывает долю отделившихся респондентов из числа живущих с родителями в каждый год с 15 до 35 лет для каждого поколения. По величине доли отделившихся в каждый год после 15-летия можно сказать, когда вероятность отделения от родителей наиболее высока в каждом поколении.

Решение второй задачи (определить, с какими событиями связано отделение от родителей) выполняется путём вычисления коэффициентов корреляции между возрастом наступления отделения от родительской семьи и возрастами наступления сопутствующих событий в жизненном пути индивида (то есть завершения получения образования, выход на рынок труда, начало сожительства с партнёром и регистрация брака).

Третья задача (определить факторы, повышающие вероятность отделения от родителей для каждого поколения) была решена с помощью построения регрессий Кокса в рамках метода «анализ наступления событий» (event history analysis) [Кокс, Оукс 1988]. Это полупараметрический метод, который позволяет определить вероятность наступления события, фиксируя прошедшее количество времени от заданной даты до наступления наблюдаемого события (в данном случае от 15 -летия до наступления отделения) [Бурдяк 2007]. Поскольку мы имеем дело с временной переменной, то для изучения факторов, влияющих на вероятность отделения от родителей, подходит именно данный метод. В ситуации цензурированных данных, то есть когда событие не успело произойти в рассматриваемый промежуток времени, в качестве даты наступления события берётся окончание опроса, но при этом факт его наступления будет равен «0», иначе говоря, «событие не наступило» [Кокс, Оукс 1988].

В качестве зависимой переменной выступает факт наступления отделения с 15 до 35 лет. При наличии данного события у респондента фиксируется количество лет, прошедших от 15-летия до наступления отделения от родителей.

В таблице 2 представлены факторы (nредикторы), которые были включены в модель. Изначально в модели также были включены такие переменные, как наличие высшего образования у родителей, характер отношений между родителями и проживание в полной семье до 15 лет. Но эти переменные оказались незначимы в моделях.

Были построены пять регрессий Кокса. Качество всех моделей высокое ( $<0,05)$. Общая модель для всей выборки даёт возможность проследить влияние эффекта поколения на время отделения от родительской семьи. Регрессия для каждого из четырёх поколений в отдельности даёт представление о силе влияния факторов для представителей каждой поколенческой группы. 
Таблиия 2

\section{Предикторы в регрессиях Кокса \\ при изучении отделения от родительской семьи}

\begin{tabular}{llc}
\hline Переменная & Категории переменной & Вид переменной \\
\hline Принадлежность к поколению & $1975-1986$ гг. p. & Номинальная \\
(категориальная) & \\
& $1930-1944$ гг. p. & Номинальная \\
Пол & $1945-1959$ гг. p. & \\
Регион проживания до 15 лет & $1960-1974$ гг. p. & Нужской \\
& Женский & Порядковая \\
Наличие братьев, сестёр & Другие города \\
& Мегаполисы* & \\
Окончание образования наивысшего уровня & Нет братьев и сестёр & \\
Первый выход на рынок труда & один, двое, & Количественная \\
Первое сожительство с партнёром & трое и больше & \\
Первый зарегистрированный брак & 15 лет до наступления & \\
\hline
\end{tabular}

* К мегаполисам мы отнесли Москву и Санкт-Петербург.

\section{Результаты анализа}

\section{Характеристика выборочной совокупности}

Из 5451 респондента, попавшего под наблюдение, в возрасте 15-35 лет родительский дом покинули 4850 человек, то есть 89\% выборки. Распределение средних возрастов отделения от родителей в интервале 15-35 лет представлено на рисунке 1.

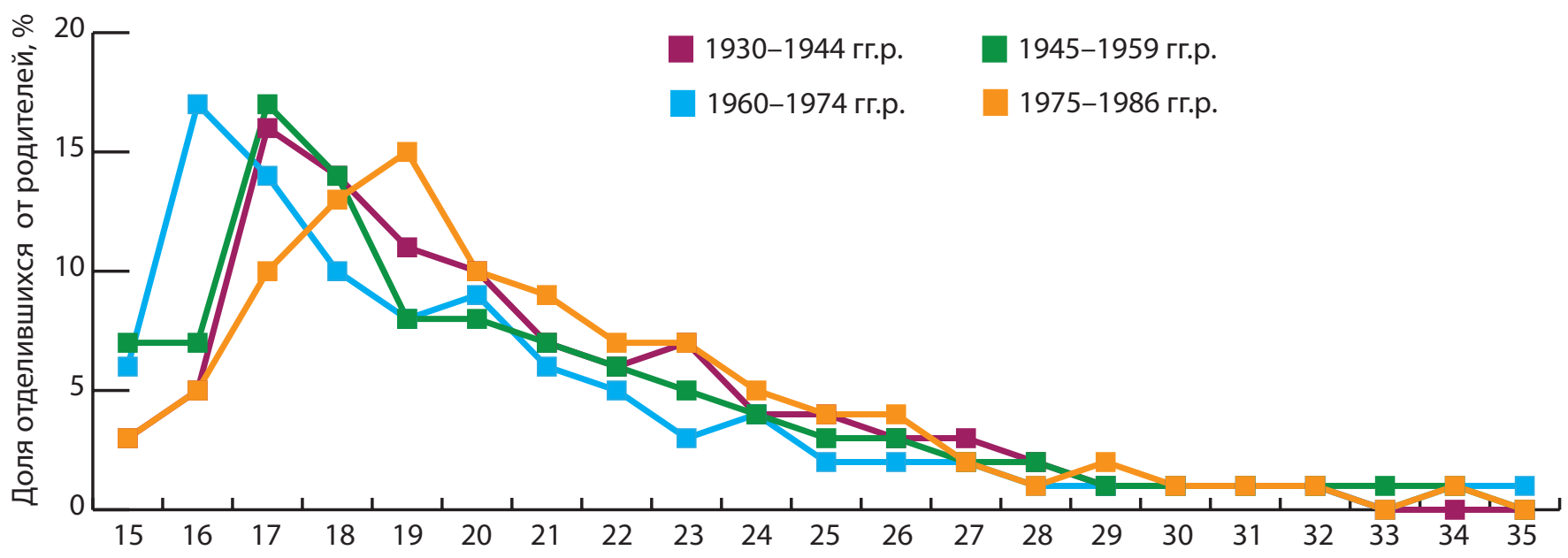

Рис. 1. Распределение возрастов отделения от родительской семьи (от 15 до 35 лет) в разрезе поколений, $N=4850$

Для поколений 1945-1959 гг. р. и 1975-1986 гг. р. 17-летие является пиковым возрастом для отделения. Для поколения 1930-1944 гг. р. такой пик приходится на 20 лет, а для поколения 1960-1974 гг. р. — на 16 лет. Если кривые для двух наиболее пожилых поколений после пиков убывают довольно монотонно, 
то на кривых, отображающих возрасты отделения молодых поколений, заметно ещё несколько небольших пиков: для поколения 1960-1974 гг. р. это 20 лет; для самых молодых - пики в окрестностях 20, 23 и 25 лет. Эти наблюдения говорят о том, что респонденты, социализировавшиеся в советское время, стремились к «среднему», «нормальному» поведению и старались вести себя так же, как сверстники. Современные же поколения демонстрируют разнообразие, рассогласованность в возрасте отделения от родителей, что может говорить о большей ориентации на себя, на свой круг общения, на референтную группу.

В целом мужчины покидают родительский дом на один-два года позже, чем женщины. В поколении 1960-1974 гг. р. («перестроечное») заметен самый низкий средний возраст отделения на рассматриваемом промежутке - 19 лет. В «околовоенном» поколении 1930-1944 гг. р. этот показатель составил 22 года, а в поколениях 1945-1959 гг. р. («доперестроечное») и 1975-1986 гг. р. («послеперестроечное») средний возраст отделения был одинаковым - 20 лет.

Поскольку мы ограничили наступление отделения от родителей 15-35 годами, то и остальные события мы подвергли такому же ограничению. В качестве важных социоэкономических и демографических событий жизненного пути мы взяли окончание получения образования наивысшего уровня, первое трудоустройство, первые незарегистрированные отношения с совместным проживанием партнёров и первый зарегистрированный брак. Ранее было объяснено, почему именно эти события являются значимыми при переходе во взрослую жизнь. В таблице 3 представлены доли респондентов в каждом поколении, у которых рассматриваемые события произошли в возрасте 15-35 лет.

Доля событий, наступивших в возрасте 15-35 лет, \% $(N=5451)$

Таблица 3

\begin{tabular}{|c|c|c|c|c|}
\hline \multirow[b]{2}{*}{ Событие } & \multicolumn{4}{|c|}{ Поколения } \\
\hline & $\begin{array}{c}\text { «Околовоенное», } \\
\text { 1930-1944 гг. p. }\end{array}$ & $\begin{array}{c}\text { «Допере- } \\
\text { строечное», } \\
\text { 1945-1959 гг. p. }\end{array}$ & $\begin{array}{c}\text { «Перестроечное», } \\
\text { 1960-1974 гг. p. }\end{array}$ & $\begin{array}{c}\text { «Послепере- } \\
\text { строечное», } \\
\text { 1975-1986 гг. p. }\end{array}$ \\
\hline Отделение от родителей & 89 & 90 & 91 & 83 \\
\hline $\begin{array}{l}\text { Окончание образования } \\
\text { наивысшего уровня }\end{array}$ & 79 & 95 & 96 & 99 \\
\hline $\begin{array}{l}\text { Первый выход на рынок } \\
\text { труда }\end{array}$ & 86 & 98 & 97 & 95 \\
\hline $\begin{array}{l}\text { Первое сожительство } \\
\text { с партнёром }\end{array}$ & 21 & 28 & 40 & 46 \\
\hline $\begin{array}{l}\text { Первый зарегистрирован- } \\
\text { ный брак }\end{array}$ & 86 & 88 & 86 & 57 \\
\hline
\end{tabular}

Из таблицы 3 видно, что отделение от родителей, получение образования, трудоустройство на первую работу были осуществлены более чем 90\% респондентов в возрасте 15-35 лет. Доля сожительств возрастает по мере приближения к молодым поколениям, в то время как доля состоящих в браке значительно падает. Для молодёжи брак становится всё менее популярным и всё чаще заменяется сожительствами без регистрации в ЗАГСе.

\section{Возраст отделения от родителей в разрезе поколений}

В рамках первой задачи мы установили момент времени, когда вероятность отделения от родителей наиболее высока в каждом поколении. На рисунке 2 представлены графические результаты построения 
таблиц жизни, а именно доли отделившихся респондентов из числа живущих с родителями в каждый год после 15-летия. Наибольшие значения этого показателя различаются в рассматриваемых четырёх поколениях: больше всего респондентов, относящихся к «околовоенному» поколению, отделилось в 19 лет, относящихся к «доперестроечному» - в 18 лет, к «перестроечному» - в 21 год, к «послеперестроечному» - в 23 года.
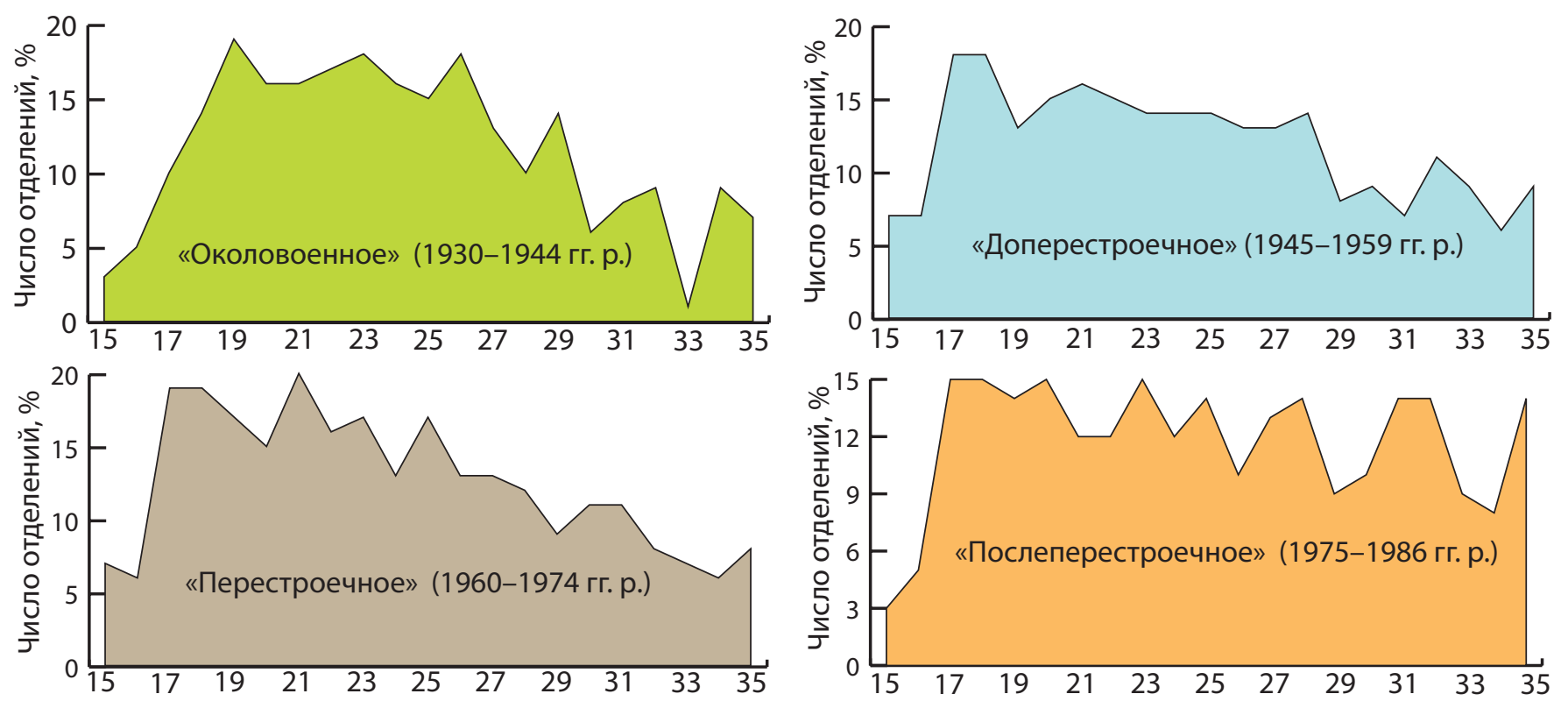

Примечание. Статистические различия по тесту Вилконсона (Гехана) значимы на уровне доверия 95\%.

Рис. 2. Распределение доли отделившихся от родителей на каждом году жизни, начиная с 15 лет и заканчивая 35 годами, \%

На рисунке 2 видно, что геометрические площади, образованные под кривыми, очень разные для разных поколений. Если в советских поколениях максимум площади приходится на первые 3-12 лет после 15-летия, а затем наблюдается резкое снижение кривой и площади под ней, то для самого молодого поколения площадь под всей кривой, начиная с двух лет, будет практически одинаковой (линия тренда практически горизонтальная). Это говорит о том, что в молодом поколении происходит рассредоточение возрастов отделения от родителей.

\section{Связь отделения и сопутствующих событий}

Коэффициенты корреляции между отделением от родителей и каждым из других значимых событий представлены в таблице 4.

Для «околовоенного» поколения отделение от родителей в большей степени связано с выходом на рынок труда (на 23\%) и регистрацией брака (на 20\%). Для «доперестроечного» поколения сохраняется та же тенденция, что и в предыдущей группе, однако начинает быть значима связь отделения и получения образования (16\%). Отрицательную связь возраста наступления сожительства и отделения можно объяснить тем, что сожительство в данной группе могло выступать в качестве аналога второму браку в более старших возрастах. Однако, так как практика разводов не была распространена в СССР [Cемёнова 2005], сила связи при данном коэффициенте очень мала. В «перестроечном» поколении резко возрастает связь отделения и получения образования (до 25\%), но связь отделения и выхода на рынок труда больше (27\%). Для самого молодого поколения отделение от родителей сильнее всего связано с получением образования (31\%), с выходом на рынок труда $(28 \%)$ и только потом - с регистрацией брака (26\%). Молодёжь больше времени уделяет образованию и карьере, и отделение от родителей на- 
чинает коррелировать именно с этими событиями. Примечательно то, что в данной группе отделение от родителей начинает быть связанным со стартом незарегистрированных отношений, а не с браком.

\section{Степень связи между возрастом отделения от родителей и возрастом наступления остальных событий}

Таблица 4

\begin{tabular}{|c|c|c|c|c|}
\hline \multirow[b]{2}{*}{ Возраст события } & \multicolumn{4}{|c|}{$\begin{array}{c}\text { Возраст отделения от родителей } \\
\text { Поколения }\end{array}$} \\
\hline & $\begin{array}{c}\text { «Около- } \\
\text { военное», } \\
1930-1944 \text { гг. } \mathrm{p} . \\
(N=1117)\end{array}$ & $\begin{array}{c}\text { «Допере- } \\
\text { строечное», } \\
1945-1959 \text { гг. } \mathrm{p} . \\
(N=1768)\end{array}$ & $\begin{array}{c}\text { «Пере- } \\
\text { строечное», } \\
1960-1974 \text { гг. p. } \\
(N=1735)\end{array}$ & $\begin{array}{c}\text { «Послепере- } \\
\text { строечное» } \\
\text { 1975-1989 гг. p. } \\
(N=831)\end{array}$ \\
\hline $\begin{array}{l}\text { Окончание образования наи- } \\
\text { высшего уровня }\end{array}$ & 0,624 & $0,160 *$ & $0,250^{*}$ & $0,310^{*}$ \\
\hline Первый выход на рынок труда & $0,230^{*}$ & $0,220 *$ & $0,270^{*}$ & $0,280^{*}$ \\
\hline $\begin{array}{l}\text { Первое сожительство с пар- } \\
\text { тнёром }\end{array}$ & $0,068^{*}$ & $-0,045^{*}$ & 0,005 & $0,210^{*}$ \\
\hline $\begin{array}{l}\text { Первый зарегистрированный } \\
\text { брак }\end{array}$ & $0,200 * *$ & $0,200 * *$ & $0,180^{* *}$ & $0,260^{*}$ \\
\hline
\end{tabular}

** Корреляция значима на уровне 0,05 .

* Корреляция значима на уровне 0,1 .

Также мы рассмотрели разницы во времени наступления событий (в месяцах) и выяснили следующее:

- выход на рынок труда предшествует отделению от родителей у 55\% респондентов «околовоенного» поколения и у 48\% «доперестроечного»; для «перестроечного» и «послеперестроечного» поколений отделение от родителей происходит позже выхода на рынок труда: 48 и 46\% соответственно;

— во всех поколениях получение образования происходило после отделения от родителей, но в «доперестроечном» поколении этот показатель выше всего (52\%);

- у представителей «послеперестроечного» поколения отделение от родительской семьи в большей степени совпадает с сожительством, чем в других поколенческих группах;

- во всех поколениях, кроме самого молодого, брак больше чем в 50\% случаев наступает после отделения.

Проанализировав связь отделения с сопутствующими событиями, стоит отметить, что по мере приближения к более молодому поколению отделение от родителей начинает быть связанным больше с социально-экономическими событиями (завершение получения образования и выход на рынок труда), нежели с матримониальными (создание семьи).

\section{Влияние факторов, включённых в модель, на время отделения от родителей}

Результаты построения пяти регрессий Кокса отображены в таблице 5. Для каждого предиктора представлены его значимость в модели и регрессионный коэффициент. Мы поместили в одну таблицу переменные для всех моделей, чтобы иметь возможность сравнить влияние факторов в разных поколениях. 


\section{Регрессионные модели Кокса для отделения от родительской семьи} в возрасте 15-35 лет

\begin{tabular}{|c|c|c|c|c|c|c|c|c|c|c|c|}
\hline \multicolumn{2}{|c|}{ Предикторы модели } & \multicolumn{2}{|c|}{$\begin{array}{c}\text { Модель } 1 \\
\text { Для всех } \\
\text { поколений } \\
(N=\mathbf{5 4 5 1 )}\end{array}$} & \multicolumn{2}{|c|}{$\begin{array}{c}\text { Модель } 2 \\
\text { «Около- } \\
\text { военное», } \\
\text { 1930-1944 гг. p. } \\
\text { (N= 1117) }\end{array}$} & \multicolumn{2}{|c|}{$\begin{array}{c}\text { Модель } 3 \\
\text { «Допере- } \\
\text { строечное», } \\
\text { 1945-1959 гг. p. } \\
\text { (N = 1768) }\end{array}$} & \multicolumn{2}{|c|}{$\begin{array}{c}\text { Модель } 4 \\
\text { «Пере- } \\
\text { строечное», } \\
\text { 1960-1974 гг. p. } \\
\text { (N= 1735) }\end{array}$} & \multicolumn{2}{|c|}{$\begin{array}{c}\text { Модель } 5 \\
\text { «Послепере- } \\
\text { строечное», } \\
\text { 1975-1986 гг. p. } \\
\text { (N=831) } \\
\end{array}$} \\
\hline & & Sig. & $\operatorname{Exp}(B)$ & Sig. & $\operatorname{Exp}(B)$ & Sig. & $\operatorname{Exp}(B)$ & Sig. & $\operatorname{Exp}(B)$ & Sig. & $\operatorname{Exp}(B)$ \\
\hline \multirow{3}{*}{ Поколение } & 1930-1944 гг. p. & 0,51 & 0,96 & & & & & & & & \\
\hline & 1945-1959 гг. p. & 0,03 & 1,11 & & $x$ & & $x$ & & r & & $x$ \\
\hline & $\begin{array}{l}\text { 1960-1974 гг. p. } \\
\text { 1975-1986 гг. p. } \\
\text { Мужчины }\end{array}$ & 0,00 & 1,22 & & & $\begin{array}{l}\boldsymbol{\sigma} \\
\mathbf{6}\end{array}$ & овая & & & & \\
\hline Пол & Женщины & 0,00 & 1,28 & 0,00 & 1,26 & 0,00 & 1,28 & 0,00 & 1,23 & 0,00 & 1,38 \\
\hline $\begin{array}{l}\text { Регион про- } \\
\text { живания до } \\
15 \text { лет }\end{array}$ & $\begin{array}{l}\text { Мегаполисы } \\
\text { Другие города }\end{array}$ & \multicolumn{10}{|c|}{ базовая } \\
\hline \multirow{3}{*}{$\begin{array}{l}\text { Наличие бра- } \\
\text { тьев, сестёр }\end{array}$} & $\begin{array}{l}\text { Нет братьев, } \\
\text { сестёр }\end{array}$ & \multicolumn{10}{|c|}{ базовая } \\
\hline & $1-2$ & 0,00 & 1,16 & 0,68 & 0,95 & 0,08 & 1,15 & 0,01 & 1,23 & 0,43 & 1,23 \\
\hline & 3 и более & 0,00 & 1,47 & 0,14 & 1,19 & 0,00 & 1,48 & 0,00 & 1,69 & 0,21 & 1,25 \\
\hline \multicolumn{2}{|c|}{$\begin{array}{l}\text { Количество лет от } 15 \text {-летия до } \\
\text { получения образования наивыс- } \\
\text { шего уровня }\end{array}$} & 0,00 & 1,13 & 0,11 & 1,12 & 0,01 & 1,21 & 0,11 & 1,12 & 0,01 & 1,31 \\
\hline \multicolumn{2}{|c|}{$\begin{array}{l}\text { Количество лет от } 15 \text {-летия до } \\
\text { первого выхода на рынок труда }\end{array}$} & 0,41 & 0,97 & 0,24 & 0,92 & 0,26 & 0,92 & 0,36 & 1,06 & 0,04 & 1,20 \\
\hline \multicolumn{2}{|c|}{$\begin{array}{l}\text { Количество лет от } 15 \text {-летия до } \\
\text { первого сожительства с партнё- } \\
\text { ром }\end{array}$} & 0,08 & 1,30 & 0,27 & 1,20 & 0,18 & 1,15 & 0,00 & 1,36 & 0,00 & 1,48 \\
\hline \multicolumn{2}{|c|}{$\begin{array}{l}\text { Количество лет от } 15 \text {-летия до } \\
\text { первого зарегистрированного } \\
\text { брака }\end{array}$} & 0,00 & 1,27 & 0,045 & 1,08 & 0,00 & 1,37 & 0,00 & 1,43 & 0,09 & 1,22 \\
\hline
\end{tabular}

Результаты полученных моделей говорят о том, что вероятность отделения от родительской семьи в определённом возрасте больше всего зависит от следующих факторов:

для представителей «доперестроечного» (1945-1959 гг. р.) и «перестроечного» (1960-1974 гг. р.) поколений вероятность отделиться в более раннем возрасте выше, чем для самого молодого поколения (1975-1986 гг. р.), на 11 и 22\% соответственно. У «околовоенного» (1930-1944 гг. р.) и «послеперестроечного» (1975-1986 гг. р.) поколений различия в вероятностях отделения незначительные, но для молодого поколения вероятность отделиться от родителей в более молодом возрасте на 4\% выше. На рисунке 4 показан график кумулятивной вероятности наступления отделения в разрезе поколений.

Кривая функции, отражающей вероятность отделения от родителей, для самого молодого «послеперестроечного» - поколения (1975-1986 гг. р.) лежит ниже всех остальных кривых. Это значит, что для самого молодого поколения риск отделиться от родителей меньше по срав- 
нению со старшими поколениями. Кривые функций для «доперестроечного» (1945-1959 гг. p.) и «околовоенного» (1930-1944 гг. р.) поколений лежат очень близко друг к другу, однако для родившихся в доперестроечные годы вероятность отделения в более раннем возрасте, до 24 лет, выше. Для «околовоенного» поколения эта вероятность выше в более позднем возрасте - после 25 лет. Выше всех находится кривая функции для «перестроечного» поколения. Именно представители этого поколения имеют бо́льшую по сравнению с остальными поколенческими группами вероятность начать жить отдельно. Исходя из коэффициентов модели и средних возрастов отделения от родительской семьи, полученных ранее, можно говорить о тенденции более позднего выхода из родительской семьи. Гипотеза 1 о том, что вероятность отделения от родителей для «послеперестроечного» (1975-1986 гг. р.) поколения будет ниже, чем для других поколенческих групп, подтверждена;

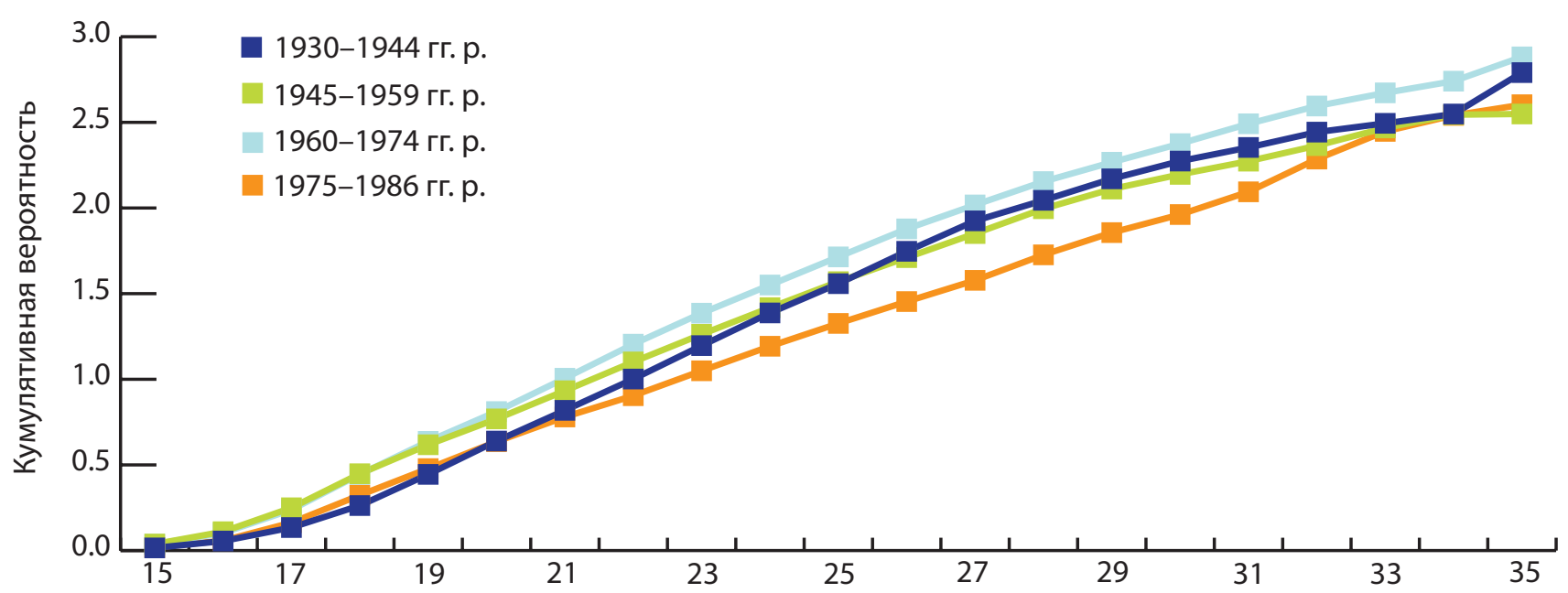

Рис. 3. Кумулятивная вероятность отделиться от родительской семьи в возрасте 15-35 лет в разрезе поколений

для женщин вероятность отделиться от родителей в среднем на $30 \%$ выше, чем для мужчин для всей выборки (см. рис. 4).

В «послеперестроечном» поколении (1975-1986 гг. р.) эта вероятность увеличивается до 38\%. Для женщин этого поколения риск отделиться после 15-летия почти в два раза выше, чем для представительниц «перестроечного» поколения (1960-1974 гг. р.). Скорее всего, это обусловлено тем, что женщины 1960-1974 гг. р. ещё наследовали модели начала отдельного проживания предыдущих поколений, в то время как для рождённых в 1975-1986 гг. условия социализации были иными в связи с распадом СССР, что повлияло на бо́льшую дифференциацию во времени выхода из родительской семьи для мужчин и женщин. Гипотеза 2 о том, что половые различия во времени отделения от родительской семьи существуют во всех поколениях, и у женщин вероятность отделиться раньше выше, чем у мужчин, подтверждена;

для тех, кто проживал в мегаполисе до 15 лет, нашла своё подтверждение гипотеза 3: вероятность начать жить отдельно в более раннем возрасте для них в среднем на $30 \%$ ниже, чем для проживающих в других городах. В первых трёх поколениях («околовоенное» (1930-1944 гг. p.), «доперестроечное» (1945-1959 гг. р.) и «перестроечное» (1960-1974 гг. р.)) влияние этого фактора постепенно увеличивается с 31 до 34\%. У самого молодого поколения - «послеперестроечного» (1975-1986 гг. р.) - значимость данного показателя возросла, а сила влияния уменьшилась (24\%). Место проживания постепенно теряет свою значимость при оценке вероятности отделиться в определённом возрасте. Это можно объяснить существованием системы 
распределения трудовых мест по всей территории СССР, причиной отделения от родителей для проживающих в малых городах была как раз трудовая мобильность. Для «послеперестроечного» поколения существуют совсем иные институциональные условия жизни, поэтому влияние данного фактора снижается;

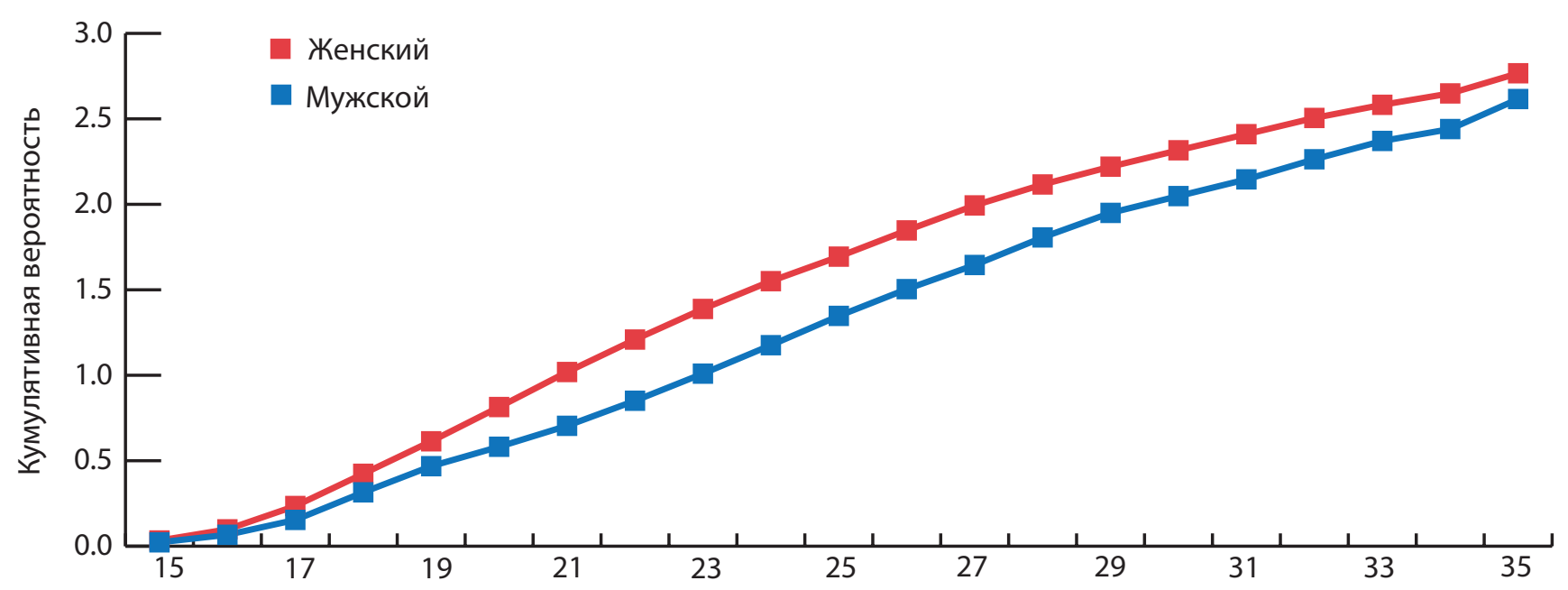

Рис. 4. Кумулятивная вероятность отделиться от родительской семьи в возрасте 15-35 лет в разрезе пола

наличие братьев и сестёр: во всех поколениях увеличение размера семьи способствует более раннему отделению от родителей, а не только в постсоветских, как предполагалось изначально (таким образом, гипотеза 4 не подтвердилась). При этом эта вероятность растёт с увеличением количества братьев и сестёр в семье. Данный фактор перестаёт быть значимым по мере приближения к «послеперестроечному» (1975-1986 гг. р.) поколению, видимо, в силу того, что в современном обществе в основном преобладают семьи с одним ребёнком, и влияние этого фактора на вероятность отделиться от родителей снижается [Захаров 2007];

в среднем для всей выборки дополнительный год от 15-летия до окончания образования увеличивает вероятность отделения на 13\%. Этот показатель оказался незначимым для «околовоенного» (1930-1944 гг. р.) и «перестроечного» (1960-1974 гг. р.) поколений; в «доперестроечном» (1945-1959 гг. р.) поколении он составил 21\%. В «послеперестроечном» (1975-1986 гг. р.) поколении эта вероятность выше всего по сравнению со всеми остальными группами и составляет $31 \%$;

дополнительный год от 15-летия до времени выхода на работу никак не влияет на вероятность отделения от родительской семьи для всех поколений, кроме лиц 1975-1986 гг. р.: для «послеперестроечного» поколения дополнительный год от 15-летия до времени выхода на рынок труда увеличивает вероятность начать жить отдельно на 20\%. При выявлении связи отделения с сопутствующими событиями в задаче 2 было установлено, что для «околовоенного» (1930-1944 гг. р.) поколения связь отделения с началом трудовой деятельности выше всего по сравнению с другими событиями. Можно поэтому сказать, что для представителей «околовоенного» (1930-1944 гг. р.) и «перестроечного» (1960-1974 гг. р.) поколений отделение от родителей в большей степени связано с выходом на рынок труда (гипотеза 5 подтверждена);

дополнительный год от 15-летия до начала сожительства с партнёром увеличивает вероятность отделения в «перестроечном» (1960-1974 гг. р.) и «послеперестроечном» (1975-1986 гг. р.) поколениях на 36 и 48\% соответственно, то есть для представителей «по- 
слеперестроечного» поколения отделение от родительской семьи в большей степени связано с сожительством с партнёром, чем в других группах (гипотеза 7 подтверждена);

дополнительный год от 15-летия до регистрации первого брака увеличивает вероятность отделиться от родителей для представителей всех поколений, кроме «послеперестроечного» (1975-1986 гг. р.). Для «околовоенного» поколения (1930-1944 гг. р.) этот показатель практически незначим (8\%). Для «доперестроечного» (1945-1959 гг. р.) и «перестроечного» (1960-1974 гг. р.) поколений дополнительный год от 15-летия до брака увеличивает вероятность отделения на 37 и 43\% соответственно. Для поколений 1945-1974 гг. р. регистрация брака способствует более быстрому отделению от родителей по сравнению с другими группами, значит, гипотеза 6 подтверждается. Отсутствие значимости данного показателя для самого молодого поколения может говорить о том, что брак в этой группе не является причиной отделения от родителей, по сравнению с сожительством, наличие которого увеличивает вероятность отделиться от родителей в дополнительный год после 15 -летия на 48\%.

Таким образом, можно сделать следующие выводы: для «послеперестроечного» (1975-1986 гг. р.) поколения отделение от родителей в большей степени наступает в связи с получением образования и началом сожительства с партнёром (31 и 48\%), в меньшей степени влияет время устройства на работу (20\%); в «перестроечном» поколении (1960-1974 гг. р.) отделение наступает с большей вероятностью при регистрации брака (43\%), однако тенденция к отделению в связи с сожительством с партнёром также заметна (36\%); в «доперестроечном» поколении (1945-1959 гг. р.) вероятность отделения увеличивается в связи с получением образования и регистрацией брака (21 и 37\% соответственно); для представителей «околовоенного» поколения (1930-1944 гг. р.) отделение от родителей не подвержено влиянию времени наступления дополнительных событий; исключение составляет регистрация брака, увеличивающая вероятность отделения на $8 \%$.

\section{Заключение}

Цель данной работы состояла в том, чтобы выявить межпоколенческие различия во времени отделения от родительской семьи и факторы, оказывающие влияние на наступление данного события. Результаты проведённого анализа в целом подтверждают выводы других исследователей о том, что межпоколенческое единообразие поведения при начале отдельного проживания нарушается, а внутри каждого поколения отделение от родителей обусловлено различными сопутствующими событиями: получение образования; выходом на рынок труда; началом сожительства с партнёром или регистрацией брака [Беляева 2004; Вишневский 2006: 137; Fussell 2002: 42; Knijn 2012: 106].

Поскольку начало проживания отдельно от родителей во многом зависит как от демографических, так и от социоэкономических факторов в обществе, полученные результаты можно объяснить различным характером институциональных условий, в которых проходила социализация представителей каждого поколения: для «околовоенного» поколения большую роль играло трудовое распределение при отделении от родителей, а также курс на восстановление народного хозяйства; жёсткие нормативные и моральные законы существовали для «доперестроечного» поколения в сфере семейных отношений, например, законодательный запрет разводов и общее порицание добрачных связей; в перестроечное время существенные изменения претерпевает экономическая сфера, возникает рынок жилья, что является одним из толчков к увеличению доли сожительств без официального оформления отношений. Институциональные условия, законы или нравственные установки представляют собой значимые маркеры эпохи, которые формируют определённые условия для социализации, задают рамки для демографического, социального, экономического поведения. Можно сказать, что по мере приближения к «послеперестроечному» поколению в институциональном поле открывается все больше свобод для 
выбора альтернативных путей планирования собственного жизненного пути. Получение образования становится альтернативой раннему выходу на рынок труда, а сожительство с партнёром - браку. Именно с этой точки зрения стоит понимать и интерпретировать полученные межпоколенческие различия при начале отдельного проживания от родителей.

Различия в возрастах наступления рассмотренных событий оказались значимыми на уровне доверия 95\% в каждом поколении, поэтому можно сказать, что в российском обществе наблюдаются тенденции Второго демографического перехода в сфере начала отдельного проживания, о котором писал Д. Ван де Каa, систематизируя опыт западных стран [Van de Kaa 1987]. Традиционная модель отделения от родителей, когда начало самостоятельного проживания в большей степени было связано с браком, сменяется современными видами поведения, когда отъезд из родительской семьи объясняется как образовательной, трудовой мобильностью, так и сожительством с партнёром [Вишневский 2006].

В рамках дальнейшей работы стоит проанализировать отделение от родительской семьи с более содержательной, интерпретативной стороны. Важно установить, куда именно происходит отделение от родительской семьи (населённый пункт, тип жилья, домохозяйства), как влияет финансовое положение семьи на вероятность отделения от родителей. Владение данной информацией интересно с двух точек зрения: во-первых, мы сможем понять, какие содержательные причины скрываются за отделением от родителей (образовательная, трудовая мобильность); во-вторых, у нас будет возможность отследить наступление других типов отделения (материального и психологического) благодаря получению информации о домохозяйстве, в котором начал проживать человек (живёт один, с друзьями, другими родственниками), а также о его материальной состоятельности (приобрел жильё за собственные деньги, существует постоянная материальная помощь от родителей или нет). Также имеет смысл обратиться к изучению вопроса о роли срочной военной службы в жизни мужчин (принудительное отделение), выявить мнения и установки людей относительно причин начала или, наоборот, откладывания времени отделения от родителей. Интересно проанализировать интерактивные эффекты взаимодействия образования и поколения в регрессионных моделях, то есть посмотреть, какова вероятность наступления отделения от родительской семьи у представителя каждого поколения при определённом уровне образования. Эти и другие перспективы для изучения отделения от родителей помогут более глубоко и содержательно рассмотреть данное событие. Они являются перспективными направлениями для дальнейших исследований в социально-демографической сфере и последующего развития темы.

\section{Литература}

Беляева Л. А. 2004. Социальный портрет возрастных когорт в постсоветской России. Соииологические исследования. 10: 31-41. URL: http://ecsocman.hse.ru/data/970/594/1231/004.BELIAEVA.pdf

Блюм А., Себий П., Захаров С. В. 2010. Семья в четырёх государствах: Франция, Грузия, Литва, Россия. В сб.: Захаров С. В.,. Прокофьева Л. М., Синявская О. В. (отв. ред.). Эволющия семьи в Европе: Восток - Запад. М.: НИСП; 11-40.

Блоссфельд Х.П., Хъюнинк И. 2006. Исследования жизненных путей в социальных науках. Журнал соииологии и сощиальной антропологии. 9 (1): 15-43. URL: http://ecsocman.hse.ru/data/793/825/1219/002Blocsfeld.pdf

Бурдяк А. Я. 2007. Применение метода «Анализ наступления события (Event History Analysis)» с помощью пакета SPSS. SPERO. 6: 189-202. URL: http://spero.socpol.ru/docs/spero_no6.pdf

Вишневский А. Г. 2006. Обновление семьи и брака. В кн.: Вишневский А. Г (отв. ред.). Демографическая модернизация России 1900-2000. М.: Новое изд-во; 66-146. URL: http://demoscope.ru/weekly/ knigi/modern/modernizacija.html 
Горшков М. К., Шереги Ф. Э. 2010. Молодёжь России: соииологический портрет. М.: ЦСПиМ; 568-574. URL: http://www.isras.ru/files/File/Molodez_Rossii.pdf

Головляницина Е. Б., Синявская О. В. 2009. Панельное обследование РиДМиЖ — новое в изучении межпоколенных и гендерных отношений в России. В сб.: Захаров С. В., Малева Т. М., Синявская О. В. (отв.ред.). Родители и дети, мужчины и женщины в семье и обществе. М.: НИСП; 323-335.

Гурко Т. А., Игнатова И. В 1997. Особенности брачного выбора в России в начале 90-х годов. Семья 8 России. 3: 51. URL: http://www.isras.ru/files/File/Publication/Gurko_Ignatova.pdf

Долбик-Воробей Т. 2003. Студенческая молодёжь о проблемах брака и рождаемости. Социологические исследования. 11: 78-84. URL: http://ecsocman.hse.ru/data/480/832/1219/010.DOLBIK-VOROBEY. pdf

Ежов О. Н. 2005. Парадигма жизненного пути в зарубежной социологии. Журнал сощииологии и сощиальной антропологии. 8 (3): 22-33. URL: http://ecsocman.hse.ru/data/631/762/1219/002-Ezhov.pdf

Захаров С. В. 2002. Растёт ли российская рождаемость? Демоскоn-Weekly. 85-86 (21 октября - 3 ноября). URL: http://demoscope.ru/weekly/2002/085/tema05.php

Захаров С. В. 2006. Брачность в России: история и современность. Демоскоn-Weekly. 261-262 (16-29 октября). URL: http://demoscope.ru/weekly/2006/0261/s_map.php\#1

Захаров С. В. 2007. Трансформация брачно-партнёрских отношений в России: «золотой век» традиционного брака близится к закату? В сб.: Малева Т. М., Синявская О. В. (отв. ред.). Родители и дети, мужчины и женщины в семье и обществе. М.: НИСП; 75-127.

Захаров С. В., Митрофанова Е. С. 2014. Демографические характеристики молодёжи России. В кн.: Горшков М. et al. (отв. ред.). Россия и Китай: молодёжь ХХІ века. М.: Новый хронограф; 55-79. URL: http://www.isras.ru/files/File/publ/Rossiya_i_Kitai_2014.pdf

Козырева П. М., Лежнина Ю. П. 2014. Репродуктивное поведение молодёжи. В кн.: Горшков М. et al. (отв. ред.). Россия и Китай: молодёжь XXI века. М.: Новый хронограф; 192-220. URL: http://www. isras.ru/files/File/publ/Rossiya_i_Kitai_2014.pdf

Кокс Д., Оукс Д. 1988. Анализ данных типа времени жизни. М.: Финансы и статистика; 9-18.

Константиновский Д. Л. 2014. Российская молодёжь: образование и занятость. В кн.: Горшков М. et al. (отв. ред.). Россия и Китай: молодёжь XXI века. М.: Новый хронограф; 283-307. URL: http://www. isras.ru/files/File/publ/Rossiya_i_Kitai_2014.pdf

Левада Ю. 2005. Поколения XX века: возможности исследования. В кн.: Левада Ю. А., Шанин Т. (отв. ред.). Отиьы и дети: поколенческий анализ современной России. М.: Новое Литературное обозрение; 39-60.

Магун В. С., Энговатов М. В. 2005. Межпоколенческая динамика жизненных притязаний молодёжи и стратегий их ресурсного обеспечения: 1985-2001 гг. В кн.: Левада Ю. А., Шанин Т. (отв. ред.). Oтщьь и дети: поколенческий анализ современной России. М.: Новое Литературное обозрение; 261-327. 
Митрофанова Е. С. 2009. Использование прикладных аспектов Теории поколений при формировании социальной, корпоративной и государственной политики. Демоскоn-Weekly. 381-382 (15-30 июня). URL: http://demoscope.ru/weekly/2009/0381/student03.php

Митрофанова Е. С. 2010. Семья и брак, матримониальное, репродуктивное и сексуальное поведение в крестьянской, советской и современной России. Демоскоn-Weekly. 423-424 (24 мая - 6 июня). URL: http://demoscope.ru/weekly/2010/0423/student01.php

Митрофанова Е. С. 2011. Демографическое поведение поколений россиян в сфере семьи и рождаемости. Экономический журнал ВШЭ. 15 (4): 519-542. URL: http://ecsocman.hse.ru/data/2012/03/26/126 9127738/15_04_08.pdf

Попова Д. О. 2009. Трансформация семейных ценностей и Второй демографический переход в России: кто в авангарде? В сб.: Захаров С. В., Малева Т. М., Синявская О. В. (отв.ред.). Родители и дети, мужчины и женщины в семье и обществе. М.: НИСП; 163-185.

Семёнова В. В. 2005. Современные концепции и эмпирические подходы к понятию «поколение» в социологии. В кн.: Левада Ю. А., Шанин Т. (отв. ред.). Отцьь и дети: поколенческий анализ современной России. М.: Новое Литературное обозрение; 80-107.

Синявская О. В., Тындик А. О. 2009. Рождаемость в современной России: от планов к действиям? В сб.: Захаров С. В., Малева Т. М., Синявская О. В. (отв.ред.). Родители и дети, мужчины и женщины в семье и обществе. М.: НИСП; 9-45.

Тындик А. О., Митрофанова Е. С. 2014. Социально-экономическое поведение индивида в зеркале концепции жизненного пути. Мониторинг общественного мнения. 3: 146-158. URL: http://wciom.ru/ fileadmin/file/monitoring/2014/121/2014_121_15_A.O.Tyndik_E.S.Mitrofanova.pdf

Чернова Ж., Шпаковская Л. 2010. Молодые взрослые: супружество, партнёрство и родительство. Дискурсивные предписания и практики в современной России. Laboratorium. Журнал couиальныхx ucследований. 3: 19-43.

Шанин Т. 2005. История поколений и поколенческая история. В кн.: Левада Ю. А., Шанин Т. (отв. ред.). Отиьы и дети: поколенческий анализ современной России. М.: Новое Литературное обозрение; 17-39.

Aassve A. et al. 2001. Leaving Home Ain't Easy. A Comparative Longitudinal Analysis of ECHP Data. Working Papers of the Max Planck Institute for Demographic Research. 38. URL: http://www.researchgate.net/ publication/258136530_Leaving_home_A_comparative_analysis_of_ECHP_data

Arnett J. J. 2000. Emerging Adulthood: A Theory of Development from the Late Teens Through the Twenties. American Psychologist. 55 (5): 469-480. URL: http://jeffreyarnett.com/articles/ARNETT_Emerging Adulthood_theory.pdf

Arnett J. J. 2004. A Longer Road to Adulthood. In: Arnett J. J. (ed.). Emerging Adulthood: The Winding Road from the Late Teens through the Twenties. New York: Oxford University Press; 3-25. URL: $\quad$ http://ir.nmu.org.ua/bitstream/handle/123456789/133201/7af07d04e6ffd9efd80f9e900f541397. pdf? sequence $=1 \&$ isAllowed $=y$ 
Billari F. C., Liefbroer A. C. 2007. Should I Stay or Should I Go? The Impact of Age Norms on Leaving Home. Demography. 44 (1): 181-198.

Billari F. C., Liefbroer A. C. 2010. Towards a New Pattern of Transition to Adulthood? Advances in Life Course Research. 15 (2-3): 59-75.

Billari F. C., Philipov D., Baizán P. 2001. Leaving Home in Europe: The Experience of Cohorts Born around 1960. International Journal of Population Geography. 7 (5): 39-356.

Blossfeld H.-P. 1986. Career Opportunities in the Federal Republic of Germany: A Dynamic Approach to the Study of Life-Course, Cohort, and Period Effects. European Sociological Review. 2 (3): 208-225.

Buck N., Scott J. 1993. She's Leaving Home: But Why? An Analysis of Young People Leaving The Parental Home. Journal of Marriage and Family. 55 (4): 863-874.

Corijn M., Klijzing E. 2001. Transitions to Adulthood in Europe. Dordrech: Kluwer Academic Publishers.

Cordon J. A. F. 1997. Youth Residential Independence and Autonomy: A Comparative Study. Journal of Family Issues. 18 (6): 576-607.

Elder G. H., Jr. 1985. Perspectives on the Life Course. In: Glen H., Elder G. H., Jr. (eds). Life Course Dynamics. Ithaca: Cornell University Press; 23-49.

Evans A. 2013. Generational Change in Leaving the Parental Home. In: Evans A., Baxter J. (eds) Negotiating the Life Course: Stability and Change in Life Pathways. Netherlands: Springer; 53-67.

Fukuda S. 2009. Leaving the Parental Home in Post-War Japan. Demographic Research. 20 (30): 731-816. URL: http://www.demographic-research.org/Volumes/Vol20/30/20-30.pdf

Furlong A. 2009. Handbook of Youth and Young Adulthood: New Perspectives and Agendas. Abingdon, Oxon, UK: Routledge.

Furstenberg F. F., Jr. 2010. On a New Schedule: Transitions to Adulthood and Family Change. The Future of Children. 20 (1): 67-87. URL: http://www.princeton.edu/futureofchildren/publications/docs/20_01_04. pdf

Fussell E. 2002. Youth in Aging Societies. In: Mortimer T., Larson R. W. (eds). The Changing Adolescent Experience: Societal Trends and the Transition to Adulthood. Cambridge: Cambridge University Press; $18-51$.

Goossens L. 2001. Transition to Adulthood: Developmental Factors. In: Corijn M., Klijzing E. (eds). Transitions to Adulthood in Europe. Dordrech: Kluwer Academic Publishers; 27-42.

Iacovou M., Skew A. 2010. Household Structure in the European Union. ISER Working Papers. Institute for Social and Economic Research. 10 (April). URL: https://www.iser.essex.ac.uk/research/publications/ working-papers/iser/2010-10.pdf

Knijn T. 2012. Work, Family Policies and Transitions to Adulthood in Europe. Netherlands: Palgrave Macmillan. 
Lesthaeghe R., Moors G. 2000. Recent Trends in Fertility and Household Formation in the Industrialized World. Review of Population and Social Policy. 9: 121-170. URL: http://www.researchgate.net/ profile/Ron_Lesthaeghe2/publication/254303794_Europe's_demographic_issues_fertility_household_ formation_and_replacement_migration/links/00b495263c031e354c000000.pdf

Mannheim K. 1952. The Problem of Generations. In: Mannheim K. (ed.). Essays on the Sociology of Knowledge. New York: Oxford University Press; 276-321.

Mitchell B. 2000. Integrating Conceptual, Theoretical and Methodological Developments in Homeleaving Research. Paper Submitted to the Workshop «Leaving Home: A European Focus». 6-8 September, Max Planck Institute for Demographic Research, Research Group on the Demography of Early Adulthood, Rostock, Germany. URL: http://www.demogr.mpg.de/Papers/workshops/000906_paper09.pdf

Mulder C. H. 2009. Leaving the Parental Home in Young Adulthood. In: Furlong A. (ed.). Handbook of Youth and Young Adulthood New Perspectives and Agendas. Abingdon, Oxon, UK: Routledge; 203-210.

Reher D. S. 1998. Family Ties in Western Europe: Persistent Contrasts. Population and Development Review. 24 (2): 203-234.

Ryder N. 1965. The Cohort as a Concept in the Study of Social Change. American Sociological Review. 30 (6): 843-861.

Shorrocks A. F. 1975. The Age-Wealth Relationship: A Cross Section and Cohort Analysis. Review of Economics and Statistics. 57 (2). May: 155-163.

Van de Kaa D. J. 1987. Europe’s Second Demographic Transition. Population Bulletin. 42 (1): 1-59.

Zorlu A., Mulder C. H. 2011. Ethnic Differences in Leaving Home: Timing and Pathways. Demography. 48 (1): 49-72. URL: http://www.researchgate.net/publication/49806805_Ethnic_Differences_in_Leaving_ Home_Timing_and_Pathways 


\title{
DEBUT STUDIES
}

\section{Alina Dolgova, Ekaterina Mitrofanova Leaving the Parental Home in Russia: Intergenerational Aspects}

\author{
DOLGOVA, Alina - Research \\ Assistant, Laboratory for \\ Studies in Economic Sociology, \\ National Research University \\ Higher School of Economics. \\ Address: 20 Myasnitskaya \\ str., Moscow, 101000, Russian \\ Federation.
}

Email: aadolgova24@gmail. com

\section{MITROFANOVA, Ekaterina - Junior Research Fellow, Laboratory of Social and Demographic Policies; Lecturer, Institute of Demography, National Research University Higher School of Economics. Address: 20 Myasnitskaya str., Moscow, 101000, Russian Federation.}

Email: mitrofanovy@yandex.ru

\begin{abstract}
Leaving home is a key life event in the transition to adulthood, but it has been relatively less explored in demographic and sociological studies of Russia. The modernization of socio-demographic behavior which started in the 1960s in Europe is described as the Second Demographic Transition. This began in Russia only in the 1990s. One characteristic of the Second Demographic Transition is that young people spend more time on education, career building, and self-realization: they use a wide range of opportunities of today's world. Current young adults prefer non-marital unions, which postpones starting a family. As a result Russian young adults (born in 1975-1986) tend to leave their parents' home at later ages than their predecessors (born in 1930-1974). The aim of this research is to examine the changes in the timing of leaving home in the perspective of four Russian generations, and set up a new model for understanding leaving home in Russia. At what age do today's young people leave the parental home, compared with previous generations? What factors influence the age at which children leave their parents' home? To answer these questions, we used the panel data of the Russian part of Generations and Gender Survey (GGS-panel: 2004, 2007, and 2011). We analyze the leaving home experience of men and women aged 15-35 years, who were born in 1930-1986. The sample size is in total 5451 respondents. Our main method of analysis is event history analysis (Cox regressions, life tables). The data illustrate that generation
\end{abstract} cohort and social variables influence the strategies of leaving home. The main finding of our research is that leaving the parental home depends on generation, and the changes of the model of leaving home are similar to European countries which experienced the Second Demographic Transition.

Keywords: leaving the parental home; life course; social and demographic behavior; intergenerational differences; Russia; generations; Event history analysis.

\section{Acknowledgements}

Research and educational group for Fertility, Family formation and dissolution was organized with support of HSE Scientific Found (Research grant No. 14-05-0055).

The authors want to express gratitude to S. Zakharov, D. Ibragimova and colleagues of Laboratory for Studies in Economic Sociology of the Higher School of Economics for helping in preparing the present research and professional guidance. 


\section{References}

Aassve A., Billari F., Mazzuco S., Ongaro F. (2001). Leaving Home Ain’t Easy. A Comparative Longitudinal Analysis of ECHP Data. Working papers of the Max Planck Institute for Demographic Research, no 38. Available at: http://www.researchgate.net/publication/258136530_Leaving_home_A_comparative_analysis_of_ECHP_data (accessed 3 October 2014).

Arnett J. J. (2000) Emerging Adulthood: A Theory of Development From the Late Teens Through the Twenties. American Psychologist, vol. 55, no 5, pp. 469-480. Available at: http://jeffreyarnett.com/articles/ ARNETT_Emerging_Adulthood_theory.pdf (accessed 18 November 2014).

Arnett J. J. (2004) A Longer Road to Adulthood. Emerging Adulthood: The Winding Road from the Late Teens through the Twenties, New York: Oxford University Press, pp. 3-25. Available at: http://ir.nmu.org.ua/bitstream/handle/123456789/133201/7af07d04e6ffd9efd80f9e900f541397.pdf? sequence=1\&isAllowed=y (accessed 18 November 2014).

Belyaeva L. (2004) Sotsial'nyy portret vozrastnykh kogort v postsovetskoy Rossii [The Social Portrait of Cohorts in Post-Soviet Russia]. Sotsiologicheskie issledovaniya, no 10, pp. 31-41. Available at: http://ecsocman.hse.ru/data/970/594/1231/004.BELIAEVA.pdf (accessed 5 February 2015) (in Russian).

Billari F. C., Liefbroer A. C. (2007) Should I Stay or Should I Go? The Impact of Age Norms on Leaving Home. Demography, vol. 44, no 1, pp. 181-198.

Billari F. C., Liefbroer A. C. (2010) Towards a New Pattern of Transition to Adulthood? Advances in Life Course Research, vol. 15, no 2-3, pp. 59-75.

Billari F. C., Philipov D., Baizán P. (2001) Leaving Home in Europe: The Experience of Cohorts Born around 1960. International Journal of Population Geography, vol. 7, no 5, pp. 339-356.

Blum A., Sebiy P., Zakharov S. (2010) Sem'ya v chetyrekh gosudarstvakh: Frantsiya, Gruziya, Litva, Rossiya [Family in Three Countries: France, Georgia, Lithuania, Russia]. Evolyutsiya sem 'i v Evrope: Vostok-Zapad [Family Evolution in Europe: East-West] (eds. S. Zakharov, L. Prokof'eva, O. Sinyavskaya), Moscow: Independent Institute for Social Policy, pp. 11-40 (in Russian).

Blossfeld H. - P. (1986) Career Opportunities in the Federal Republic of Germany: A Dynamic Approach to the Study of Life-Course, Cohort, and Period Effects. European Sociological Review, vol. 2, no 3 (December), pp. 208-225. Available at: http://esr.oxfordjournals.org/content/2/3/208.short (accessed 5 October 2014).

Blossfeld H. - P., Huinink J. (2006) Issledovaniya zhiznennykh putey v sotsial'nykh naukakh [Life Course Studies in Social Sciences]. The Journal of Sociology and Social Anthropology, vol. 9, no 1 (34), pp. 1543. Available at: http://ecsocman.hse.ru/data/793/825/1219/002-Blocsfeld.pdf (accessed 15 March 2015) (in Russian).

Buck N., Scott J. (1993) She's Leaving Home: But Why? An Analysis of Young People Leaving The Parental Home. Journal of Marriage and Family, vol. 55, no 4, pp. 863-874.

Burdyak A. (2007) Primenenie metoda “Analiz nastupleniya sobytiya (Event History Analysis)”s pomoshch'yu paketa SPSS [Application of the Event History Analysis Using SPSS Package]. Social Policy: Expertise, Recommendations, Overviews, no 6, pp. 189-202. Available at: http://spero.socpol.ru/docs/spero_no6.pdf (accessed 15 March 2015) (in Russian). 
Chernova Z., Shpakovskaya L. (2010) Molodye vzroslye: supruzhestvo, partnerstvo i roditel'stvo. Diskursivnye predpisaniya i praktiki v sovremennoy Rossii [Young Adults: Marriage, Partnership and Parenthood. Discursive Prescriptions and Practice in Modern Russia]. Laboratorium. Journal of Social Studies, no 3, pp. 19-43.

Cordon J. A. F. (1997) Youth Residential Independence and Autonomy: A Comparative Study. Journal of Family Issues, vol. 18, no 6, pp. 576-607.

Corijn M., Klijzing E. (2001) Transitions to Adulthood in Europe, Dordrech: Kluwer Academic Publishers.

Dolbik-Vorobey T. (2003) Studencheskaya molodezh' o problemakh braka i rozhdaemosti [Student Youth about the Problems of Marriage and Fertility]. Sotsiologicheskie issledovaniya, no 11, pp. $78-84$ (in Russian).

Elder G. H., Jr. (1985) Perspectives on the Life Course. Life Course Dynamics (eds. H. Glen, G. H. Elder, Jr.), Ithaca: Cornell University Press. pp. 23-49.

Evans A. (2013) Generational Change in Leaving the Parental Home. Negotiating the Life Course: Stability and Change in Life Pathways (eds. A. Evans, J. Baxter), Netherlands: Springer, pp. 53-67.

Ezhov O. (2005) Paradigma zhiznennogo puti v zarubezhnoy sotsiologii [The Paradigm of Life Course in Foreign Sociology]. The Journal of Sociology and Social Anthropology, vol. 8, no 3, pp. 22-22. Available at: http://ecsocman.hse.ru/data/631/762/1219/002-Ezhov.pdf (accessed 15 March 2015) (in Russian).

Fukuda S. (2009) Leaving the Parental Home in Post-War Japan. Demographic Research, vol. 20, no 30, pp. 731-816. Available at: http://www.demographic-research.org/Volumes/Vol20/30/20-30.pdf (accessed 12 March 2015).

Furlong A. (2009) Handbook of Youth and Young Adulthood: New Perspectives and Agendas, Abingdon, Oxon, UK: Routledge.

Furstenberg F. F., Jr. (2010) On a New Schedule: Transitions to Adulthood and Family Change. The Future of Children, vol. 20, no 1, pp. 67-87. Available at: http://www.princeton.edu/futureofchildren/publications/ docs/20_01_04.pdf (accessed 9 November 2014).

Fussell E. (2002) Youth in Aging Societies. The Changing Adolescent Experience: Societal Trends and the Transition To Adulthood (eds. J. T. Mortimer, R. W. Larson), Cambridge: Cambridge University Press, pp. 18-51.

Golovlyanitsina E., Sinyavskaya O. (2009) Panel'noe obsledovanie RiDMiZh — novoe v izuchenii mezhpokolennykh i gendernykh otnosheniy v Rossii [RiDMiZh Panel Study — the Study of a New Intergenerational and Gender Relations in Russia]. Roditeli $i$ deti, muzhchiny $i$ zhenshhiny $v$ sem'e $i$ obshchestve [Parents and Children, Men and Women in Family and Society] (eds. S. Zakharov, T. Maleva, O. Sinyavskaya), Moscow: Independent Institute for Social Policy, pp. 323-335 (in Russian).

Gorshkov M., Sheregi F. (2010) Molodezh'Rossii: sotsiologicheskiy portret [The Youth of Russia: Sociological Portrait] (electronic book), Moscow: Center for Social Forecasting and Marketing, pp. 568-574. Available at: http://www.isras.ru/files/File/Molodez_Rossii.pdf (accessed 2 November 2014) (in Russian). 
Goossens L. (2001) Transition to Adulthood: Developmental Factors. Transitions to Adulthood in Europe (eds. M. Corijn, E. Klijzing), Dordrech: Kluwer Academic Publishers, pp. 27-42.

Gurko T., Ignatova I. (1997) Osobennosti brachnogo vybora v Rossii v nachale 90-kh godov [Features of Marital Choice in Russia in the Early 90s]. Family in Russia, no 3, p. 51. Available at: http://www.isras.ru/ files/File/Publication/Gurko_Ignatova.pdf (accessed 12 February 2015) (in Russian).

Iacovou M., Skew A. (2010) Household Structure in the European Union. ISER Working Papers, Institute for Social and Economic Research, no 10 (April). Available at: https://www.iser.essex.ac.uk/research/publications/working-papers/iser/2010-10.pdf (accessed 10 October 2014).

Knijn T. (2012) Work, Family Policies and Transitions to Adulthood in Europe, Netherlands: Palgrave Macmillan.

Koks D., Ouks D. (1988) Analiz dannykh tipa vremeni zhizni [The Analysis of Lifetimes Data], Moscow: Finance and Statistics, pp. 9-18 (in Russian).

Konstantinovskiy D. (2014) Rossiyskaya molodezh': obrazovanie i zanyatost' [Russian Youth: Education and Employment]. Rossiya i Kitay: molodezh'XXI veka [Russia and China: The Youth of the XXI Century] (eds. M. Gorshkov, L. Chunlin', Z. Golenkova, P. Kozyreva), Moscow: New Chronograph, pp. 283-307. Available at: http://www.isras.ru/files/File/publ/Rossiya_i_Kitai_2014.pdf (accessed 18 March 2015) (in Russian).

Kozyreva P., Lezhnina Y. (2014) Reproduktivnoe povedenie molodezhi [Reproductive Behavior of Youth]. Rossiya i Kitay: molodezh'XXI veka [Russia and China: The Youth of the XXI Century] (eds. M. Gorshkov, L. Chunlin', Z. Golenkova, P. Kozyreva), Moscow: New Chronograph, pp. 192-220. Available at: http:// www.isras.ru/files/File/publ/Rossiya_i_Kitai_2014.pdf (accessed 2 November 2014) (in Russian).

Lesthaeghe R., Moors G. (2000) Recent Trends in Fertility and Household Formation in the Industrialized World. Review of Population and Social Policy, no 9, pp. 121-170. Available at: http:/www.researchgate. net/profile/Ron_Lesthaeghe2/publication/254303794_Europe's_demographic_issues_fertility_household_formation_and_replacement_migration/links/00b495263c031 e354c000000.pdf (accessed 10 October 2014).

Levada Y. (2005) Pokoleniya XX veka: vozmozhnosti issledovaniya [Generation of XX Century: The Possibility of Studying]. Ottsy i deti: pokolencheskiy analiz sovremennoy Rossii [Fathers and Sons: Generational Analysis of Modern Russia] (eds. Y. Levada, T. Shanin), Moscow: New Literary Observer Publishing House, pp. 39-60 (in Russian).

Magun V., Engovatov M. (2005) Mezhpokolencheskaya dinamika zhiznennykh prityazaniy molodezhi i strategiy ikh resursnogo obespecheniya: 1985-2001 gg. [Intergenerational Dynamics of Youth Life Aspirations and Their Strategies of Resource Support: 1985-2001 Years]. Ottsy i deti: pokolencheskiy analiz sovremennoy Rossii [Fathers and Sons: Generational Analysis of Modern Russia] (eds. Y. Levada, T. Shanin), Moscow: New Literary Observer Publishing House, pp. 261-327 (in Russian).

Mannheim K. (1952) The Problem of Generations. Essays on the Sociology of Knowledge (ed. K. Mannheim), New York: Oxford University Press, pp. 276-321. 
Mitchell B. (2000) Integrating Conceptual, Theoretical and Methodological Developments in Homeleaving Research. Paper Submitted to the Workshop "Leaving Home: A European Focus". 6-8 September, Max Planck Institute for Demographic Research, Research Group on the Demography of Early Adulthood, Rostock, Germany. Available at: http://www.demogr.mpg.de/Papers/workshops/000906_paper09.pdf (accessed 3 March 2015).

Mitrofanova E. (2009) Ispol'zovanie prikladnykh aspektov Teorii pokoleniy pri formirovanii sotsial'noy, korporativnoy i gosudarstvennoy politiki [The Application of Generation Theory During the Social, Corporate and Public Policy Formation]. Demoscope-Weekly (electronic journal), no 381-382. June 15-30. Available at: http://demoscope.ru/weekly/2009/0381/student03.php (accessed 15 October 2014) (in Russian).

Mitrofanova E. (2010) Sem'ya ibrak, matrimonial'noe, reproduktivnoe i seksual'noe povedeniev krest'yanskoy, sovetskoy i sovremennoy Rossii [Family and Marriage, Matrimonial, Reproductive and Sexual Behavior in the Peasant, Soviet and Modern Russia]. Demoscope-Weekly (electronic journal), no 423-424. May $24-$ June 06. Available at: http://demoscope.ru/weekly/2010/0423/student01.php (accessed 15 October 2014) (in Russian).

Mitrofanova E. (2011). Demograficheskoe povedenie pokoleniy rossiyan v sfere sem'i i rozhdaemosti [Demographic Behavior s of Russian Generations in the Sphere of Family and Fertility]. Economic Journal of HSE, vol. 15, no 4, pp. 519-542. Available at: http://ecsocman.hse.ru/data/2012/03/26/1269127738/15_0 4_08.pdf (accessed 9 November 2015) (in Russian).

Mulder C. H. (2009) Leaving the Parental Home in Young Adulthood. Handbook of Youth and Young Adulthood New Perspectives and Agendas (ed. A. Furlong), Abingdon, Oxon, UK: Routledge, pp. 203-210.

Popova D. (2009) Transformatsiya semeynykh tsennostey i vtoroy demograficheskiy perekhod v Rossii: kto v avangarde? [The Transformation of Family Values and the Second Demographic Transition in Russia Who are at the Forefront?]. Roditeli i deti, muzhchiny i zhenshhiny v sem'e i obshchestve [Parents and Children, Men and Women in Family and Society] (eds. S. Zakharov, T. Maleva, O. Sinyavskaya), Moscow: Independent Institute for Social Policy, pp. 163-185 (in Russian).

Reher D. S. (1998) Family Ties in Western Europe: Persistent Contrasts. Population and Development Review, vol. 24, no 2, pp. 203-234. Available at: http://www.jstor.org/stable/2807972? seq=1\#page_scan_tab_contents (accessed 10 March 2015).

Ryder N. (1965) The Cohort as a Concept in the Study of Social Change. American Sociological Review, vol. 30, no 6, pp. 843-861. Available at: http://www.jstor.org/stable/2090964?seq=1\#page_scan_tab_contents (accessed 25 February 2015).

Semenova V. (2005) Sovremennye kontseptsii i empiricheskie podkhody k ponyatiyu "pokolenie" v sotsiologii. [Modern Concepts and Empirical Approaches to the Concept of "Generation" in Sociology]. Ottsy $i$ deti: pokolencheskiy analiz sovremennoy Rossii [Fathers and Sons: Generational Analysis of Modern Russia] (eds. Y. Levada, T. Shanin), Moscow: New Literary Observer Publishing House, pp. 80-107 (in Russian).

Sinyavskaya O., Tyndik A. (2009) Rozhdaemost' v sovremennoy Rossii: ot planov k deystviyam? [Fertility in Modern Russia: From Plans into Action?] Roditeli i deti, muzhchiny i zhenshhiny v sem'e $i$ obshhestve [Parents and Children, Men and Women in Family and Society] (eds. S. Zakharov, T. Maleva, O. Sinyavskaya), Moscow: Independent Institute for Social Policy, pp. 9-45 (in Russian). 
Shanin T. (2005) Istoriya pokoleniy i pokolencheskaya istoriya. [History of Generations and Generational History]. Ottsy i deti: pokolencheskiy analiz sovremennoy Rossii [Fathers and Sons: Generational Analysis of Modern Russia] (eds. Y. Levada, T. Shanin), Moscow: New Literary Observer Publishing House, pp. 17-39 (in Russian).

Shorrocks A. F. (1975) The Age-Wealth Relationship: A Cross Section and Cohort Analysis. Review of Economics and Statistics, vol. 57, no 2, May, pp. 155-163.

Tyndik A., Mitrofanova E. (2014) Sotsial'no-ekonomicheskoe povedenie individa v zerkale kontseptsii zhiznennogo puti [Socio-Economic Behavior in the Individual Life Course]. The Monitoring of Public Opinion, no 3 (121), pp. 146-158. Available at: http://wciom.ru/fileadmin/file/monitoring/2014/121/2014 _121_15_A.O.Tyndik_E.S.Mitrofanova.pdf (accessed 8 November 2015) (in Russian).

Van de Kaa D. J. (1987) Europe's Second Demographic Transition. Population Bulletin, vol. 42, no 1, pp. 1-59.

Vishnevskiy A. (2006) Obnovlenie sem'i i braka [Updating the Family and Marriage]. Demograficheskaya modernizatsiya Rossii 1900-2000 [Demographic Modernization in Russia 1900-2000], Moscow: New Publishing House, pp. 66-146 (in Russian).

Zakharov S. (2002) Rastet li rossiyskaya rozhdaemost'? [Does the Russian Birth Rate Rise?] DemoscopeWeekly (electronic journal), no 85-86. October 21 - November 3. Available at: http://demoscope.ru/ weekly/2002/085/tema05.php (accessed 17 October 2014) (in Russian).

Zakharov S. (2006) Brachnost' v Rossii: istoriya i sovremennost' [Marriages in Russia: Past and Present]. Demoscope-Weekly (electronic journal), no 261-262. October 16-29. Available at: http://demoscope.ru/ weekly/2006/0261/s_map.php\#1 (accessed 17 October 2014) (in Russian).

Zakharov S. (2007) Transformatsiya brachno-partnerskikh otnosheniy v Rossii: "zolotoy vek" traditsionnogo braka blizitsya k zakatu? [The Transformation of Matrimonial and Partnership Relations in Russia: Is the "Golden Age" of Traditional Marriage Coming to a Close?] Roditeli i deti, muzhchiny i zhenshhiny v sem'e i obshchestve [Parents and Children, Men and Women in Family and Society] (eds. T. Maleva, O. Sinyavskaya), Moscow: Independent Institute for Social Policy, pp. 75-127 (in Russian).

Zakharov S., Mitrofanova E. (2014) Demograficheskie kharakteristiki molodezhi Rossii [The Demographic Characteristics of the Russian Youth]. Rossiya i Kitay: molodezh'XXI veka [Russia and China: The Youth of the XXI Century] (eds. M. Gorshkov, L. Chunlin', Z. Golenkova, P. Kozyreva), Moscow: New Chronograph, pp. 55-79. Available at: http://www.isras.ru/files/File/publ/Rossiya_i_Kitai_2014.pdf (accessed 17 March 2015) (in Russian).

Zorlu A., Mulder C. H. (2011). Ethnic Differences in Leaving Home: Timing and Pathways. Demography, vol. 48, no 1, pp. 49-72. Available at: http://www.researchgate.net/publication/49806805_Ethnic_Differences_in_Leaving_Home_Timing_and_Pathways (accessed 27 February 2015).

Received: August 25, 2015.

Citation: Dolgova A., Mitrofanova E. (2015) Otdelenie ot roditel'skoy sem'i v Rossii: mezhpokolencheskiy aspekt [Leaving the Parental Home in Russia: Intergenerational Aspects]. Journal of Economic Sociology = Ekonomicheskaya sotsiologiya, vol. 16, no 5, pp. 46-76. Available at http://ecsoc.hse.ru/2015-16-5.html (in Russian). 


\title{
ПРОФЕССИОНАЛЬНЫЕ ОБЗОРЫ
}

\author{
Т. С. Карабчук, А. А. Моисеева, Н. Э. Соболева
}

Исследование зарубежных методик

и отечественных практик определения

\section{экономического ущерба, наносимого гибелью в результате ДТП 1}

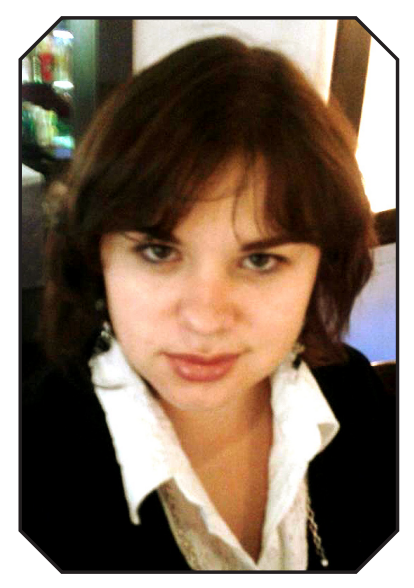

КАРАБЧУК Татьяна Сергеевна - кандидат социологических наук, доцент кафедры экономической социологии, заместитель заведующего Лабораторией сравнительных социальных исследований, старший научный сотрудник Лаборатории экономикосоциологических исследований НИУ ВШЭ. Адрес: Россия, 101000, Москва, ул. Мясницкая, д. 20.

Email: tkarabchuk@hse. ru
Статья посвящена обзору подходов и анализу методов оценки стоимости социально-экономического ущерба, наносимого гибелью в результате ДТП в России и за рубежсм. Актуальность проблемы определяется высокими показателями смертности в результате ДТП в нашей стране по сравнению с другими странами. На данный момент Россия по абсолютным и относительным показателям количества ДТП и смертности в них значительно опережает страны Евросоюза, а также Канаду и США. При этом размер ущерба от гибели людей в ДТП оценивается значительно ниже, чем в развитых странах. Данная ситуачия недооченки стоимости человеческой жизни в России подробно рассматривалась нами в статье прошлого года [Карабчук et al. 2014], где был сделан вывод о том, что отечественные показатели стоимости человеческой жизни сопоставимы с показателями развиваюшихся стран Азии, несмотря на положительные тенденции увеличения российского человеческого капитала более чем вдвое за последние годы [Капелюшников 2012]. Сочиальные и экономические последствия недооченки человеческой жизни в стране могут негативно отразиться как на индивидуальном качестве жизни россиян, так и на государственном уровне в виде ущерба от потерь экономически активного населения и затрат государства на компенсацию сочиально-экономического ущчерба семьям пострадавших. Именно поэтому выработка новых, отвечающих современным реалиям теоретических основ оценки ущерба от ДТП сегодня приобрела особую актуальность для России. Данная статья наџелена на то, чтобы поднять проблему недостаточного обсуждения последствий низкой безопасности дорожного движения в отечественной литературе. Сравнительный анализ сочиильно-экономического ущерба и методик его оиенивания в развитых странах позволит выработать адекватный научно обоснованный подход к оцениванию ущерба от ДТП в нашей стране, что в свою очередь будет способствовать сокращению показателей смертности через развитие и финансовую поддержку программ безопасности дорож-

Исследование осуществлено в рамках Программы фундаментальных исследований НИУ ВШЭ в 2015 г. Исследование осуществлено в рамках Программы фундаментальных исследований НИУ ВШЭ в 2015 г. Материалы исследования использовались в последствии для выполнения работ в рамках проведения комплексных научных исследований, направленных на создание аналитических методов поддержки принятия решений и управления в сфере безопасности дорожного движения для Главного управления по обеспечению безопасности дорожного движения МВД России. 


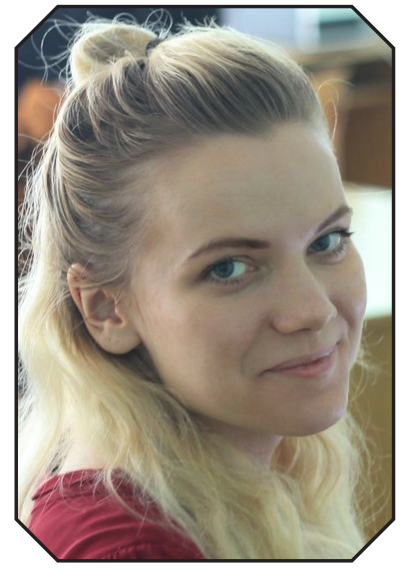

МОИСЕЕВА Анита

Андреевна - стажёрисследователь

Лаборатории

сравнительных

социальных

исследований НИУ ВШЭ. Адрес: Россия, 101000, Москва, ул. Мясницкая, д. 20.

\section{Email: aamoiseeva@} hse.ru

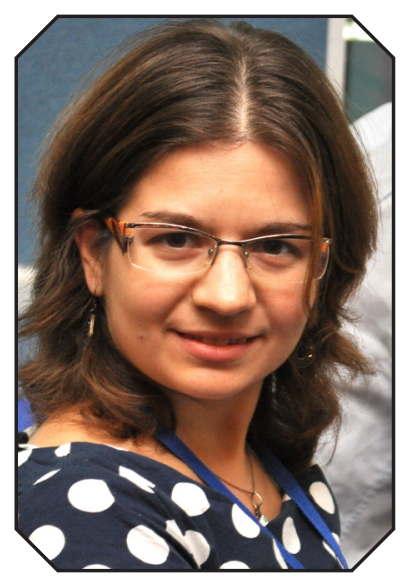

\section{СОБОЛЕВА Наталья}

Эдуардовна - кандидат социологических наук, научный сотрудник

Лаборатории

сравнительных

социальных исследований

НИУ ВШЭ. Адрес:

Россия, 101000, Москва, ул. Мясницкая, д. 20.

Email: nsoboleva@hse.ru ного движения. В данной статье мы рассмотрим международный опыт оченки стоимости сочиально-экономического ущерба от ДТП и сравним его с отечественным опытом. В заключении будут подведены итоги сопоставления ситуачии в России и развитых странах и сделаны выводырекомендации по улучшению оченочного аппарата измерения социальноэкономического ущерба от гибели людей в ДТП.

Ключевые слова: стоимость социально-экономического ущерба от ДТП; смертность на дорогах; гибель в результате ДТП; подходы к оценке стоимости человеческой жизни; человеческий капитал; сравнительный анализ.

\section{Введение}

Динамика стандартизованного коэффициента смертности от ДТП в России значительно отличается от аналогичных показателей в других странах. Если в развитых странах Европы, в Канаде и Австралии коэффициент смертности от ДТП постепенно сокращался с середины 1970-х гг. и к 2010 г. достиг четырёх-семи погибших на 100 тыс. жителей, то в России, наоборот, наблюдается тенденция роста с 1960-х гг., и к 2010 г. коэффициент смертности от ДТП составил почти 20 человек на 100 тыс. жителей [WHO Mortality Data base].

Необходимо отметить, что для отдельных регионов России эта проблема действительно является очень важной, так как ситуация там критическая. Так, если в целом по стране доля умерших от всех видов транспортных несчастных случаев в числе умерших от внешних причин в 2014 г. составляла примерно 20\%, то в Ленинградской, Новгородской, Калужской и КарачаевоЧеркесской областях, например, этот показатель достигает 32-35\%, а в Республике Тыва он равен 50\% [Щербакова 2015].

Высокие показатели смертности от транспортных несчастных случаев должны мотивировать государство на то, чтобы оно выделяло больше средств на минимизацию рисков и сокращение смертельных исходов. Ведь рост качества человеческих ресурсов является в современной ситуации одним из основополагающих условий успешного развития страны.

Необходимо знать, насколько велика сумма ущерба для государства от потери человеческих ресурсов, чтобы делать соответствующие вложения. К сожалению, в отечественной литературе и практике нет единого подхода к расчёту экономического ущерба от потери жизни. В каждой сфере, будь то страхование жизни или выплата государственных компенсаций, свои методы оценки. Эта проблема отсутствия единой методологии расчёта характерна не только для нашей страны: в 2000 г. только 13 стран Европы имели официальные оценки стоимости человеческой жизни [Miller 2000].

Оценка экономического бремени в результате ДТП должна предусматривать максимально полный учёт всех потерь, которые общество и государство несёт в связи со смертью, полной или частичной утратой трудоспособности пострадавшего. Данная оценка должна учитывать тяжесть последствий 
ДТП для отдельного человека и его семьи, издержки производственного характера, недополученный доход, а также временной интервал реабилитации, лечения и потери трудоспособности в этот период. Для этого необходима методика оценки социально-экономического ущерба, которая была бы научно обоснована и сопоставима с аналогичными методиками других стран. Обзор зарубежного опыта, сделанный в данной статье, а также анализ ситуации в России позволят это сделать.

Прежде всего, дадим краткую характеристику современных научных подходов к оценке стоимости социально-экономического ущерба от потери человеческой жизни в результате ДТП. Затем рассмотрим рекомендации Еврокомиссии, Всемирной организации здравоохранения (ВО3), Организации экономического сотрудничества и развития (ОЭСР) по определению стоимости ущерба от ДТП и представим подробный анализ зарубежных методик определения социально-экономического ущерба, наносимого гибелью в результате ДТП. Анализируются методики, существующие в международной практике служб транспортной полиции четырёх развитых стран - Австралии, Канады, США и Великобритании. Далее мы анализируем ситуацию в России и проводим аналогии отечественных практик с общепринятыми международными стандартами оценки стоимости потери человеческой жизни в результате ДТП. Подводя итоги, мы делаем ряд выводов и даём рекомендации по использованию подходов измерения стоимости ущерба от потери человеческой жизни для нашей страны.

\section{Научные подходы к оценке стоимости человеческой жизни}

Существуют три подхода к оценке стоимости потерь от утраты человеческой жизни: (1) концепция человеческого капитала; (2) концепция стоимости среднестатистической жизни и (3) субъективная оценка стоимости жизни, измеряемая через готовность населения платить за сокращение рисков. Опишем кратко эти подходы, чтобы в дальнейшем опираться на них при анализе зарубежного опыта оценки социально-экономического ущерба от ДТП.

\section{Подход к оценке стоимости человеческой жизни, основанный на оценке человеческого капитала}

Концепция человеческого капитала [Shultz 1968; Becker 1975] является одним из наиболее распространённых подходов к оценке стоимости человеческой жизни. Суть данного подхода состоит в том, что стоимость жизни человека представляет собой сумму доходов человека, которые он производит в течение своей жизни. При оценке ущерба от смерти человека рассчитывается недополученный доход, который мог бы принести человек с определёнными характеристиками. Таким образом, оценка ущерба приравнивается к оценке выгод, которые общество приобретёт от сохранения жизни или здоровья человека с определённым набором социально-экономических характеристик.

Сферы применения подхода к оценке стоимости жизни в рамках теории человеческого капитала различны. Методика в основном используется для измерения ущерба от прямых причин смерти, инвалидизачии и травматизма, хронических и прочих болезней (например, от диабета в Латинской Америке [Barcelo et al. 2003], от всех видов хронических болезней в Аргентине, Мексике, Колумбии и Бразилии [Abegund et al. 2006; Abegund et al. 2007], от сахарного диабета в Колумбии [Gonzalez et al. 2009], от рака в Китае [Kim et al. 2002]) и от дорожно-транспортных происшествий в Бельгии [Aertsens et al. 2010], в Мексике [Pérez-Núñez et al. 2011], в США [Corso et al. 2006], в Иордании [Al' Masaeid et al. 1999] и др.). Главной причиной универсальности подхода является его акцент на уменьшение производительности труда населения стран из-за ущерба от факта смертности и ущерба здоровью, а не на сами причины смертности. 
В чистом виде подход применяется в малом количестве стран. Примером стран, где применяется исключительно подход оценки стоимости человеческой жизни с точки зрения теории человеческого капитала, являются Германия и Дания [Bahamonde-Birke, Kunert, Link 2015]. Синтез подхода оценки с точки зрения теории человеческого капитала с другими применяется в ряде развитых стран: в США, Австралии, Великобритании, Бельгии, Австрии, Швейцарии и др. [Bahamonde-Birke, Kunert, Link 2015].

Основные преимущества теории человеческого капитала включают, во-первых, возможность получения дифференцированной оценки социально-экономического ущерба от смерти индивидов, обладающих разной полезностью и для рынка труда, и для общества в целом; во-вторых, доступность данных по социально-экономическим показателям, необходимых для расчёта ущерба по этой методике (Всемирный банк, Международная организация труда и др.).

Однако подход к оценке стоимости жизни с точки зрения человеческого капитала имеет несколько недостатков. Поскольку он является ретроспективным (ex-post) [Abelson 2007], итоговая стоимость жизни выражается как сумма упущенных выгод индивида, связанных с выбытием пострадавшего из сферы трудовой оплачиваемой деятельности после аварии, а следовательно, внимание акцентируется на размере заработной платы или доходах индивида до момента аварии. Более того, подход критикуется за его экономически утилитарную направленность и пренебрежение многими социальноэкономическими факторами. Во-первых, стоимость жизни экономически неактивного населения и безработных в рамках данного подхода часто приравнивается к нулю [Landefeld, Seskin 1982]. Boвторых, полезная неоплачиваемая деятельность индивида за пределами рынка труда часто остаётся неучтённой при расчётах на основе данных о заработной плате. В-третьих, оценка стоимости жизни в рамках теории человеческого капитала не учитывает стоимость морального ущерба потерпевшего, а также стоимость страданий его родственников и друзей, ухудшение качества их жизни в будущем [Abelson 2003].

На практике недостатки преодолеваются с помощью использования дополнительных элементов расчёта. Наглядным примером является исследование, посвящённое оценке уровня ущерба от аварийности в Государстве Бруней-Даруссалам (Юго-Восточная Азия), где для наиболее точного измерения объёма государственного ущерба от ДТП был использован подход «человеческий капитал»с дополнительной оценкой стоимости нерыночной занятости [ADB ASEAN 2003]. В методику расчёта была включена оценка ущерба от смертности, инвалидизации и травматизма не только работающего населения страны, пострадавшего в результате дорожно-транспортных происшествий, но и остального экономически неактивного населения.

\section{Подход к оценке стоимости человеческой жизни, основанный на стоимости среднестатистической жизни человека}

В зарубежной научной литературе большое внимание уделяется методике оценки стоимости среднестатистической жизни человека (value of statistical life) (см.: [Viscusi, Aldy 2003; Ashenfelter 2006] и др.). Оценка среднестатистической жизни - это оценка затрат на её поддержание на протяжении жизненного цикла человека, от рождения до смерти, складывающаяся из величины средних расходов человека на поддержание своей жизнедеятельности и выплат федеральных и муниципальных властей (расходов государства) на разных этапах жизни человека.

Данный подход часто используется страховыми компаниями при оценивании стоимости жизни человека и государственными организациями при расчёте компенсационных выплат в случае смерти индивида по разным причинам. Например, в США оценки стоимости среднестатистической жизни даются целым рядом организаций, включая Агентство по охране окружающей среды (United States 
Environmental Protection Agency - EPA), Службу экономических исследований Департамента сельского хозяйства США и Управление по санитарному надзору за качеством пищевых продуктов и медикаментов Министерства здравоохранения и социальных служб США (Food and Drug Administration FDA). Методика оценки среднестатистической жизни человека применяется также при межстрановых исследованиях [Wang, Не 2010].

Одно из преимуществ данного подхода заключается в открытости доступа к необходимым для расчётов данных. Другое преимущество состоит в том, что оценки при использовании такого подхода являются усреднёнными и одинаковыми для всех людей всех возрастов. И наконец, оценки в рамках такого подхода легко сопоставимы между собой, что удобно для межстрановых сравнительных исследований [Wang, He 2010] и наблюдения тенденций в динамике.

В то же время усреднённые оценки в рамках подхода «стоимость среднестатистической жизни» являются одновременно его слабой стороной. Кроме того, суммарный доход общества может распределяться между индивидами произвольным образом, а концентрация доходов - быть диспропорциональной, что противоречит предпосылке о равнозначности индивидуальных благосостояний, заложенной в основу подхода.

Одним из способов корректировки оценки стоимости среднестатистической жизни является применение критерия Роулза [Огородников, Брызгалова 2004], согласно которому общественное благосостояние рассматривается как благосостояние наименее обеспеченных слоёв населения. Стоимость человеческой жизни в данном случае будет существенно ниже определённой по методике стоимости среднестатистической жизни человека.

Таким образом, при разработке методики среднестатистической оценки ущерба от гибели человека нужно учитывать экономическую ситуацию в стране и проводимую социальную политику. Показателем степени неравенства в распределении доходов в стране могут служить коэффициент Джини и кривая Лоренца ${ }^{2}$. Если коэффициент Джини высокий и разрыв между обеспеченными и бедными слоями населения большой, измерение стоимости человеческой жизни в рамках «среднестатистического» подхода становится слишком обобщённым. По данным Росстата, в 2014 г. этот коэффициент в России был равен 41,6\%, что говорит о высоком уровне социального неравенства [Росстат]. На основе полученных среднестатистических оценок сложно разрабатывать целенаправленные правительственные программы по повышению безопасности дорожного движения.

Данные недостатки можно устранить за счёт синтеза «среднестатистического» подхода к оценке ущерба от ДТП и подхода «человеческий капитал» или же включить в анализ информацию о готовности населения платить за повышение безопасности.

\section{Подход к оценке стоимости человеческой жизни, основанный на субъективной оценке стоимости жизни и готовности населения платить за повышение безопасности}

В середине 1970-х гг. был разработан новый подход к оценке стоимости ущерба от потери жизни человека, который позволяет преодолеть недостатки методик по измерению стоимости жизни при рас-

2 Коэффициент Джини (Gini coefficient) - показатель, характеризующий степень отклонения фактического распределения доходов (или потребительских расходов) отдельных лиц или домашних хозяйств в определённой стране от абсолютного равенства. Кривая Лоренца показывает кумулятивный процент общего полученного дохода в отношении кумулятивного числа реципиентов начиная с беднейших индивидов или домашних хозяйств. Коэффициент Джини определяет расстояние между кривой и гипотетической линией абсолютного равенства, выражая в процентах максимальную площадь под кривой. Значение индекса изменяется от 0 (абсолютное равенство) до 100 (абсолютное неравенство); см. подробнее: URL: http://www.un.org/ru/development/hdr/2010/hdr_2010_technotes.pdf 
чёте прямых потерь и отражает субъективные оценки и предпочтения населения по снижению рисков смертности и ранений в тех или иных происшествиях [Mishan 1971]. Подход является элементом более широкой теоретической концепции анализа затрат и выгод (cost-benefit analysis), так как основан на измерении готовности или согласия населения платить за повышение качества жизни и общественную безопасность (willingness to pay approach - WTP) и на измерении желания населения принять определённую сумму денег в качестве компенсации (willingness to accept - WTA). Было показано, что между результатами измерения готовности платить за улучшение условий и измерения сумм желательных компенсационных выплат есть существенные различия [Horowitz, McConnell 2003], так как восприятие риска до происшествия (ex ante risk) и после него (ex post risk) существенно различается [Рearce, Atkinson, Mourato 2006].

В контексте безопасности дорожного движения (БДД) следует измерять восприятие риска до ДТП и готовность населения платить за снижение вероятности стать жертвой ДТП [Bahamonde-Birke, Kunert, Link 2015]. Таким образом, подход согласуется с оценкой транспортных проектов по повышению БДД, где потенциальные проблемы должны быть решены до наступления определённого инцидента. Более того, субъективная оценка стоимости жизни учитывает такие важные для человека аспекты, как чувство безопасности, соотношение рисков, субъективная оценка моральных страданий, стоимость жизни как таковой, стоимость проектов по повышению безопасности окружающей среды и т. д.

Оценка, уже включающая различные компоненты, варьируется лишь в зависимости от анализируемых ситуаций и уровня восприятия рисков. Общая оценка стоимости жизни в различных контекстах, таких как безопасность дорожного движения, социальная политика, политика здравоохранения и право применения, может привести к разным результатам [Viscusi, Magat, Huber 1991; Jones-Lee, Loomes 1995]. Согласно данным по странам ОЭСР за 2012 г., индивиды в большей степени готовы платить за улучшение экологии (10 млн долл. США), на втором месте с небольшим отрывом стоит улучшение безопасности дорожного движения (8 млн долл. США), на третьем - вклады в здравоохранение (4 млн долл. США) [OECD IRTAD 2014].

Метод «готовность платить» основывается на опросных данных и отражает субъективную оценку населением суммы в денежном эквиваленте, которую они готовы заплатить за снижение риска ДТП и повышение качества жизни в стране. При этом в рамках подхода «готовность платить» выделены два метода подсчёта: один - на индивидуальном и другой - на социальном уровнях. Индивидуальная готовность платить за спасение своей жизни в денежном эквиваленте не является корректной для расчёта и не подходит для принятия инвестиционных решений по улучшению дорожно-транспортной инфраструктуры. Социальная готовность платить считается подходящей для этой цели, потому что позволяет оценить, сколько индивид готов заплатить за предотвращение ДТП и повышение безопасности дорожно-транспортного движения для других индивидов или определённой группы населения.

Таким образом, общественная готовность заплатить за устранение или сведение к минимуму потенциального риска смерти, травматизма или повреждения имущества в результате несчастного случая эквивалентна суммарному рыночному индивидуальному спросу на повышение личной безопасности и безопасности других людей [Bahamonde-Birke, Kunert, Link 2015].

В рамках подхода «готовность платить» можно выделить три методики опроса, а именно гедоническое ценообразование (hedonic pricing method), условное оценивание (contingent valuation method), оценивание гипотетических рисков (social contingency methods) [Van de Kaa 2010; Hjorth, Fosgerau 2011]. С помощью методики «гедоническое ценообразование» определяется готовность индивида платить за дополнительное техническое оснащение своего автотранспортного средства, которое, в свою очередь, усиливает безопасность в целом. В рамках методики «условное оценивание» индивидам предлагается 
назвать сумму, сколько они готовы заплатить за снижение риска гибели в ДТП по шкале в денежном выражении. По третьей методике, «оценивание гипотетических рисков», помимо методики условного оценивания, респондентам представляются реальные данные по количеству ДТП со смертельным исходом и с тяжёлыми последствиями в конкретной географической области в течение определённого периода времени [Hojman, Ortúzar, Rizzi 2005]. Более того, респонденты решают, сколько они готовы заплатить за повышение безопасности, принимая во внимание полученную информацию, но при этом учитывая величину своего дохода. Данная методика является более полной и понятной для респондентов, но одновременно и более трудоёмкой [Bahamonde-Birke, Kunert, Link 2015].

Преимущество подхода «готовность платить» состоит в возможности получения субъективной общественной оценки стоимости жизни населения страны. Также метод является одним из наиболее удобных и практичных для применения в социальной политике, так как результаты расчётов позволяют распределить ограниченные государственные финансовые ресурсы более рационально и эффективно, что способствует максимизации общественного благосостояния [Landefeld, Seskin 1982]. Так, при инвестиционных решениях учитываются желаемые результаты инвестиционных вложений (например, снижение рисков от смерти и угрозы качеству жизни населения страны), определённые цели достижения (например, достижение равенства и социальной справедливости) и контекст (например, ситуации масштабных катастроф, авиакатастроф и ДТП) [Richardson 1999].

В то же время у подхода есть ряд существенных недостатков, первый из которых состоит в том, что респондент часто указывает стоимостные оценки независимо от реальной готовности платить [Parish 1991]. Кроме того, результатом исследования часто становится широкий диапазон значений, на основе которого сложно дать реальную количественную оценку стоимости жизни. Также проведение качественного национального социологического опроса требует значительных временны́х и денежных затрат. Наконец, результаты, полученные с помощью методики «готовность платить», могут идти вразрез с данными доступной статистической информации, что подчеркнёт несоответствие оценок субъективного и объективного подходов.

\section{Зарубежный опыт оценивания стоимости социально-экономического ущерба, наносимого гибелью в результате ДТП}

\section{Обзор и анализ подходов международных организаций к оценке социально-экономического ущерба, наносимого гибелью в результате ДТП}

Международные организации предлагают разные способы оценки стоимости социально-экономического ущерба от ДТП. Сначала рассмотрим опыт Еврокомиссии.

В отчёте Еврокомиссии за 2014 г. по проблемам дорожно-транспортной безопасности стран Европейского союза представлена динамика показателей смертности в результате ДТП [European Commission 2015]. Известно, что в 2010 г. в странах ЕС была поставлена цель сократить число погибших на дорогах до 2020 г. в два раза. За 2010-2013 гг. наблюдаемая динамика показателей смертности от ДТП совпадала с планом и за три года снизилась на 18\%. Однако в 2013-2014 гг. намеченного улучшения показателей не произошло, количество смертельных исходов от ДТП снизилось на 1\% против планируемых $8 \%$. Авторы отчёта подчёркивают, что тенденция остаётся положительной, несмотря на значительные различия по странам: в Швеции, Нидерландах, Великобритании и на Мальте число смертельных исходов от ДТП продолжает оставаться минимальным; в Финляндии, Словении и Хорватии наблюдается значительное снижение показателей смертности за последний год, и число погибших в этих трёх странах снизилось в среднем на 15\%. А вот в Литве, Болгарии, Румынии и Латвии за последние годы наблюдалось повышение количества смертельных исходов от ДТП. 
Стоит отметить, что при анализе дорожно-транспортной ситуации в странах Европы специалисты предлагают проводить мониторинг уровня безопасности представителей различных возрастных групп населения, пешеходов, мотоциклистов и велосипедистов, а также выделять временны́е периоды (месяц, день недели, час), в течение которых риски смертельного исхода от ДТП увеличиваются. Анализ возрастной структуры потерпевших в результате ДТП показал, что количество ДТП со смертельным исходом среди молодых людей Европы продолжает значительно снижаться, что говорит о положительной динамике. В то же время стоит отметить, что за 2013-2014 гг. в ряде стран ЕС увеличилась смертность пешеходов и велосипедистов.

Таким образом, после определения динамики уровня смертности от ДТП в странах Европы и выявления наиболее уязвимых участников дорожного движения Еврокомиссией была предложена дальнейшая стратегия по увеличению безопасности с акцентом на изменение городской инфраструктуры стран ЕС в пользу безопасности пешеходов и велосипедистов.

Ещё один важный вопрос дорожно-транспортной безопасности стран Европейского союза — анализ несмертельных, но серьёзных дорожно-транспортных происшествий, а также предложение стратегий по улучшению ситуации травматизма от ДТП. Ожидается, что в 2015 г. появятся новые общеевропейские данные о дорожно-транспортном травматизме, полученном в результате ДТП, что облегчит понимание реального масштаба проблемы и станет первым шагом в направлении сокращения травматизма на дорогах.

Стоит подчеркнуть, что подробный описательный анализ тенденций дорожно-транспортной безопасности без учёта стоимости общего ущерба от ДТП позволяет определить основные проблемы государственной политики в сфере безопасности дорожного движения и разработать наиболее актуальную и эффективную целевую стратегию борьбы с выявленными проблемами.

Далее, для определения размеров финансирования программ по обеспечению безопасности дорожного движения на национальном уровне и необходимости выделения средств с прочими общественно значимыми компонентами производится оценка социально-экономического ущерба от ДТП.

Еврокомиссия использует смешанный подход к определению стоимости ущерба, наносимого гибелью в результате ДТП, объединяя оценки в рамках двух научных подходов [European Commission 2007]: (1) оценка ущерба с точки зрения теории человеческого капитала (высчитывается на основе упущенных чистых доходов пострадавших с вычетом налогов (нетто) или доходов без вычета налогов (брутто)); (2) оценка ущерба с точки зрения готовности населения платить за повышение качества жизни и общественную безопасность (индивидуальные и общественные выплаты на повышение БДД). Кроме этого, даётся общая оценка стоимости компенсационных выплат, выплачиваемых в случае гибели человека в результате ДТП. Общая схема представлена в таблице 1.

Таблица 1

Общая схема определения стоимости ущерба, наносимого гибелью, получением травм и инвалидностью в результате ДТП, рекомендуемая Еврокомиссией

\begin{tabular}{|c|c|c|}
\hline \multicolumn{3}{|c|}{ Методы оценки стоимости ущерба от ДТП } \\
\hline 它苗 & $\begin{array}{l}\text { Подход с точки зрения теории человече- } \\
\text { ского капитала }\end{array}$ & $\begin{array}{l}\text { Субъективный подход с точки зрения готовности } \\
\text { населения платить за сокращение рисков }\end{array}$ \\
\hline 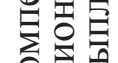 & Чистый доход с вычетом налогов (нетто) & Индивидуальные выплаты на повышение БдД \\
\hline 急 & Доход без вычета налогов (брутто) & Общественные выплаты на повышение БДД \\
\hline
\end{tabular}

Источник: [European Commission 2007]. 
Такая методика оценки ущерба позволяет оценить преимущества предотвращения дорожнотранспортных происшествий, а именно сравнить стоимость государственных потерь от смерти или ранения человека в ДТП со стоимостью предотвращения ДТП с помощью вложений в улучшение дорожно-транспортной инфраструктуры и иных мер предотвращения ДТП в денежном измерении. Оценки на основе теории человеческого капитала используются для определения величины стоимости потерянного производственного потенциала погибшего в результате ДТП, в то время как подход «готовность платить» учитывает величину стоимости утраченного качества жизни. Таким образом, подходы нацелены на привлечение добровольных индивидуальных отчислений и государственных вложений в пользу безопасности дорожного движения.

Однако, согласно некоторым статьям, общественная готовность снизить риск гибели или травматизма в ДТП с помощью вложений в повышение безопасности дорожного движения напрямую зависит от государственных нормативно-правовых актов по установлению лимитов скорости в государстве, правил по использованию ремней безопасности пассажирами транспортных средств (ТС) и других мер по предотвращению аварийности на дорогах [Miller 2000; Strand 2005; Hakes, Viscusi 2007]. Именно поэтому основную ответственность за сокращение количества ДТП и предотвращение социальноэкономического ущерба, наносимого гибелью при авариях на дорогах, несёт государство.

Теперь обратимся к способам оценки стоимости социально-экономического ущерба от ДТП в странах ОЭСР. Страны ОЭСР совместно с Международным банком данных по ДТП и интенсивности движения (International Road Traffic and Accident Database - IRTAD) производят статистический учёт дорожно-транспортных происшествий и фиксируют стоимость их социально-экономических последствий. В странах ОЭСР предлагается рассчитывать общую стоимость ущерба от ДТП как сумму ущерба, нанесённого гибелью людей в результате ДТП, и стоимости имущественных потерь от дорожнотранспортных происшествий. Однако единого подхода к оценке стоимости ущерба от потери жизни и здоровья населения в результате ДТП ОЭСР не предлагает. Большинство стран используют два научных подхода к оценке стоимости человеческой жизни - «человеческий капитал» и «готовность платить» [OECD IRTAD 2014]; в некоторых странах оценка стоимости ущерба базируются на расчёте прямых издержек или на оценке стоимости общих убытков национального объёма производства. Таким образом, в странах ОЭСР научные подходы адаптированы к национальным условиям, и оценка производится на основе доступных статистических данных, в большей или меньшей мере охватывающих переменные, необходимые для учёта ДТП и расчёта ущерба от ДТП.

Однако использование разных подходов в странах ОЭСР не позволяет проводить межстрановой сравнительный анализ. Во-первых, значения итоговых оценок стоимости ущерба от ДТП по странам зависят от особенностей подходов, в рамках которых они получены: значения показателей, рассчитанных в рамках подхода «готовность платить», выше итоговых значений, рассчитанных с помощью других подходов. В связи с этим, научный подход имеет существенное влияние на результаты расчётов. Во-вторых, уровень развития страны и ВВП на душу населения положительно коррелируют с итоговым значением стоимости ущерба от гибели или ранения в результате ДТП граждан конкретной страны: более низкие показатели среднедушевого ВВП занижают стоимость ущерба от ДТП, и наоборот. Следовательно, уровень среднедушевого ВВП в стране и его учёт в методике имеют значительное влияние на итоговую оценку стоимости ущерба от ДТП.

Всемирная организация здоровья ведёт учёт наличия статистических данных о смертельных и несмертельных исходах в результате ДТП. Конкретную методику оценки стоимости ущерба, наносимого гибелью в результате ДТП, ВОЗ не предлагает, однако разрабатывает рекомендации по развитию системного подхода к повышению безопасности дорожного движения на основе оценок масштаба дорожно-транспортного травматизма и гибели в результате ДТП. 
В докладе ВОЗ за 2013 г. для каждой страны, участвующей в исследовании, представлена стоимостная «оценка вклада в ВВП, недополученного из-за ДТП», рассчитанная национальными статистическими службами стран на основе национальных данных и предпочитаемых ими научных подходов к оценке [ВО3 2013]. В целом систематизированные оценки по каждой стране, представленные в докладе ВО3, можно отнести к подходу, используемому для определения стоимости общих убытков национального объёма производства, позволяющему рассчитать общий объём ущерба от ДТП в стране. Недостатком подхода ВОЗ к оценке стоимости ущерба от ДТП является несопоставимость результатов расчёта «недополученного ВВП» разных стран, так как страны используют разный набор учитываемых параметров (стоимость ущерба от гибели населения в результате ДТП, стоимость ущерба от травматизма в результате ДТП, компенсационные выплаты и др.) и разные подходы («человеческий капитал», «готовность платить», «среднестатистический подход», «стоимость прямых издержек», синтез подходов и др.). Для того чтобы понять, насколько оценки стоимости ущерба от ДТП различаются, следует отдельно рассматривать примеры национальных исследований в области расчёта стоимости человеческой жизни.

Далее представлен анализ зарубежных практик определения экономического ущерба в таких развитых странах, как США, Канада, Австралия и Великобритания.

\section{Анализ методики определения экономического ущерба, используемой транспортной полицией США, Канады, Великобритании и Австралии}

Исполнительный орган Министерства транспорта США (US Department of Transportation) - Национальная администрация безопасности дорожного движения (National Highway Traffic Safety Administration) - публикует отчёты о состоянии безопасности дорожного движения. В отчётах методом «затрат и выгод» анализируется эффективность программ по повышению безопасности дорожного движения путём сравнения количества выделенных на улучшение дорожной ситуации средств и текущей стоимости ущерба от гибели и ранения населения страны в результате ДТП. Также в отчётах публикуется стоимость ущерба от гибели и ранения населения страны в результате ДТП и прописывается методика расчёта общей стоимости ущерба от ДТП.

Согласно рекомендациям Национальной администрации безопасности дорожного движения США, стоимость экономического ущерба, полученного в результате ДТП, оценивается с помощью синтеза методик, а именно как сумма стоимости непосредственного ущерба от ДТП (в рамках подхода «человеческий капитал»), стоимости внешнего ущерба от ДТП (имущественный и экологический ущерб, нанесённый в результате дорожно-транспортного происшествия) и стоимости субъективно оценённого ущерба от ДТП (в рамках подхода «готовность платить»). Всего при расчёте общей стоимости ущерба, нанесённого гибелью в результате ДТП, используются 10 переменных (подробнее см. в табл. 3: США). На основе данной методики была высчитана общая стоимость экономического ущерба от ДТП в США, она составила 241988 млн долл. в год.

Национальная администрация безопасности дорожного движения приводит также оценки стоимости отдельных элементов ущерба, наносимого в результате ДТП, рассчитывая доли стоимости элементов ущерба от оценённой общей стоимости ущерба [Blincoe et al. 2015] (см. табл. 2). Таким образом, можно отметить больший вклад в стоимость непосредственного ущерба от ДТП таких элементов, как рыночные потери $(23,8 \%)$, медицинские издержки $(9,7 \%)$, нерыночные издержки и страховые потери (8,2 и 8,5\% соответственно). Доля стоимости внешнего ущерба от ДТП также велика: доля стоимости имущественного ущерба от общей стоимости ущерба составляет $31,4 \%$, доля стоимости экологического ущерба - 11,6\%. Следует отметить, что доля стоимости субъективно оценённого ущерба от общей стоимости ущерба при анализе не приводится, хотя по другим результатам анализа мы знаем, что 
стоимость ущерба, оценённая в рамках подхода «готовность платить», превосходит оценки стоимости остальных элементов ущерба примерно в семь раз и более 3 , следовательно, является наиболее значимым и весомым элементом расчёта общей стоимости ущерба от ДТП.

Таблиияа 2

Доля стоимости элементов ущерба от ДТП в общей стоимости ущерба

\begin{tabular}{|c|c|}
\hline Элементы общей стоимости ущерба & $\begin{array}{l}\text { Доля стоимости элементов в } \\
\text { общей стоимости ущерба, \% }\end{array}$ \\
\hline \multicolumn{2}{|l|}{ Стоимость непосредственного ущерба: } \\
\hline — медицинские издержки & 9,7 \\
\hline — административные издержки & 0,4 \\
\hline — рыночные потери & 23,8 \\
\hline — нерыночные потери & 8,2 \\
\hline — страховые издержки & 8,5 \\
\hline — расходы нанимающей организации & 1,9 \\
\hline — юридические издержки & 4,5 \\
\hline — доля стоимости непосредственного ущерба от ДТП & 57 \\
\hline \multicolumn{2}{|l|}{ Стоимость внешнего ущерба: } \\
\hline — стоимость экологического ущерба & 11,6 \\
\hline — стоимость имущественного ущерба & 31,4 \\
\hline — доля стоимости внешнего ущерба от ДТП & 43 \\
\hline Всего & 100 \\
\hline
\end{tabular}

Источник: [Blincoe et al. 2015: 11].

Транспортная полиция Канады предлагает оценивать стоимость экономического ущерба, полученного в результате ДТП, с помощью трёх подходов: (1) расчёт стоимости прямых издержек («ES-5.1 Direct Collision Costs»); (2) расчёт стоимости косвенных издержек в рамках подхода «стоимость человеческого капитала» («ES-5.2 Indirect Collision Costs: Human Capital Costs») и (3) расчёт стоимости косвенных издержек в рамках подхода «готовность платить» («ES-5.3 Indirect Collision Costs: Willingness-to-Pay Costs») (подробнее см. табл. 3: Канада). Стоит отметить, что методика оценки стоимости экономического ущерба от ДТП различается внутри страны в зависимости от региона, так как в Канаде исследования состояния дорожного движения в отдельных районах проводятся региональными центрами. В данном обзоре мы рассматриваем методику столичного региона Канады, которая наиболее часто применяется для расчёта стоимости ущерба от ДТП [Leur et al. 2010].

Стоит отметить, что эта методика является сложной для воспроизведения и вызывает много сомнений и вопросов. Так, стоимость моральных и физических страданий рассчитывается в рамках подхода «человеческий капитал», а не в рамках общепринятого подхода «субъективная оценка моральных страданий». Стоимость экологического ущерба входит в рамки расчёта «прямых экономических издержек», хотя к ним не относится и является «внешним ущербом от ДТП». Некоторые параметры рассчитываются в методике два раза. Например, потери производительности труда в случае гибели в результате ДТП («рыночные потери») учитываются в рамках расчёта «прямых экономических издержек», а также в рамках подхода «человеческий капитал» как потери дохода от гибели, инвалидизации и потери про-

3 В 2010 г. субъективно оценённый ущерб был равен 7747082 долл. по сравнению с 1398916 долл. оценённого объективного ущерба [Blincoe et al. 2015: 118]. 
изводительности труда пострадавшим в результате ДТП. На основе данной методики была высчитана общая стоимость экономического ущерба от ДТП в США, и на 2010 г. она составляла 16283 млн долл.; оценённая стоимость ущерба от смерти одного человека равнялась 7457 долл. [Pitel, Solomon 2013].

В Австралии стоимость экономического ущерба, полученного в результате ДТП, оценивается с помощью двух подходов: с точки зрения (1) стоимости человеческого капитала и (2) готовности населения платить за повышение безопасности дорожного движения [BITRE 2010]. Причём значения стоимости ущерба, полученные в рамках второго подхода, объединили в себе не только оценку неэкономических и неимущественных расходов, таких как стоимость морального ущерба и потери качества жизни, но и стоимость социальных последствий ДТП, понесённых пострадавшим и членами его семьи (оценка стоимости социального ущерба от ДТП) [Hensher et al. 2009].

Расчёт стоимости ущерба от ДТП в Австралии производится в зависимости от исхода ДТП: смертельный случай (гибель участника ДТП) и несмертельный (ранение или инвалидизация участника ДТП), а также в зависимости от природы оценки параметра (статистическая оченка стоимости ряда элементов ущеерба, основанная на установленных государством нормах оценки того или иного параметра ущерба, и субъективно оиенённая стоимость, основанная на опросных данных) (подробнее см. табл. 3: Австралия).

В последнем отчёте Бюро инфраструктуры, транспорта и региональной экономики Австралии были приведены следующие оценки: стоимость ущерба от гибели одного человека в результате ДТП составляет 10594 долл. США, стоимость экономического ущерба от ДТП в Австралии оценивалась суммой 2366 млн долл. США в год [BITRE 2014: 62].

В Великобритании оценка стоимости ущерба от смертельных и несмертельных несчастных случаев ДТП основана на готовности населения платить за повышение безопасности дорожного движения. Официально данный подход используется правительственными органами Великобритании с 1993 г. [GB 2013], и именно в Великобритании он был разработан. Однако в общем подходе некоторые переменные, включённые в общую стоимость ущерба от ДТП, основываются на количественном расчёте, а некоторые являются субъективно оценёнными.

Оценка стоимости ущерба от ДТП включает все аспекты потерь пострадавшего в результате ДТП, а именно: стоимость ущерба от физической боли и моральных страданий; прямые экономические издержки от потери трудоспособности, медицинские расходы, связанные с лечением травм, полученных в результате дорожно-транспортных происшествий. В дополнение к прямым расходам пострадавших в Великобритании для каждого случая ДТП рассчитываются стоимость повреждения имущества, стоимость вызова полиции на место ДТП, стоимость работы агентов по страхованию. Значения каждой составляющей общей оценки ущерба от ДТП оцениваются отдельно, а затем суммируются.

Таким образом, понятие совокупного ущерба от дорожно-транспортного происшествия в Великобритании включает две отдельные категории ущерба: индивидуальный ущерб пострадавшего в ДТП лица и ущерб, связанный с инцидентом ДТП, или с «потерями от ситуации ДТП» (подробнее см. табл. 3: Beликобритания). Степень потерь также зависит от тяжести последствий (смертельный исход, тяжёлое ранение, лёгкое ранение). Оценённая стоимость ущерба от смерти одного человека в результате ДТП в Великобритании равнялась 8137 долл. США [Jones-Lee, Spackman 2013], что меньше, чем в Канаде, но больше, чем в Австралии. 
Таблица 3

Методики оценки стоимости ущерба, нанесённого гибелью и ранением людей в результате ДТП, применяемые в четырёх развитых странах

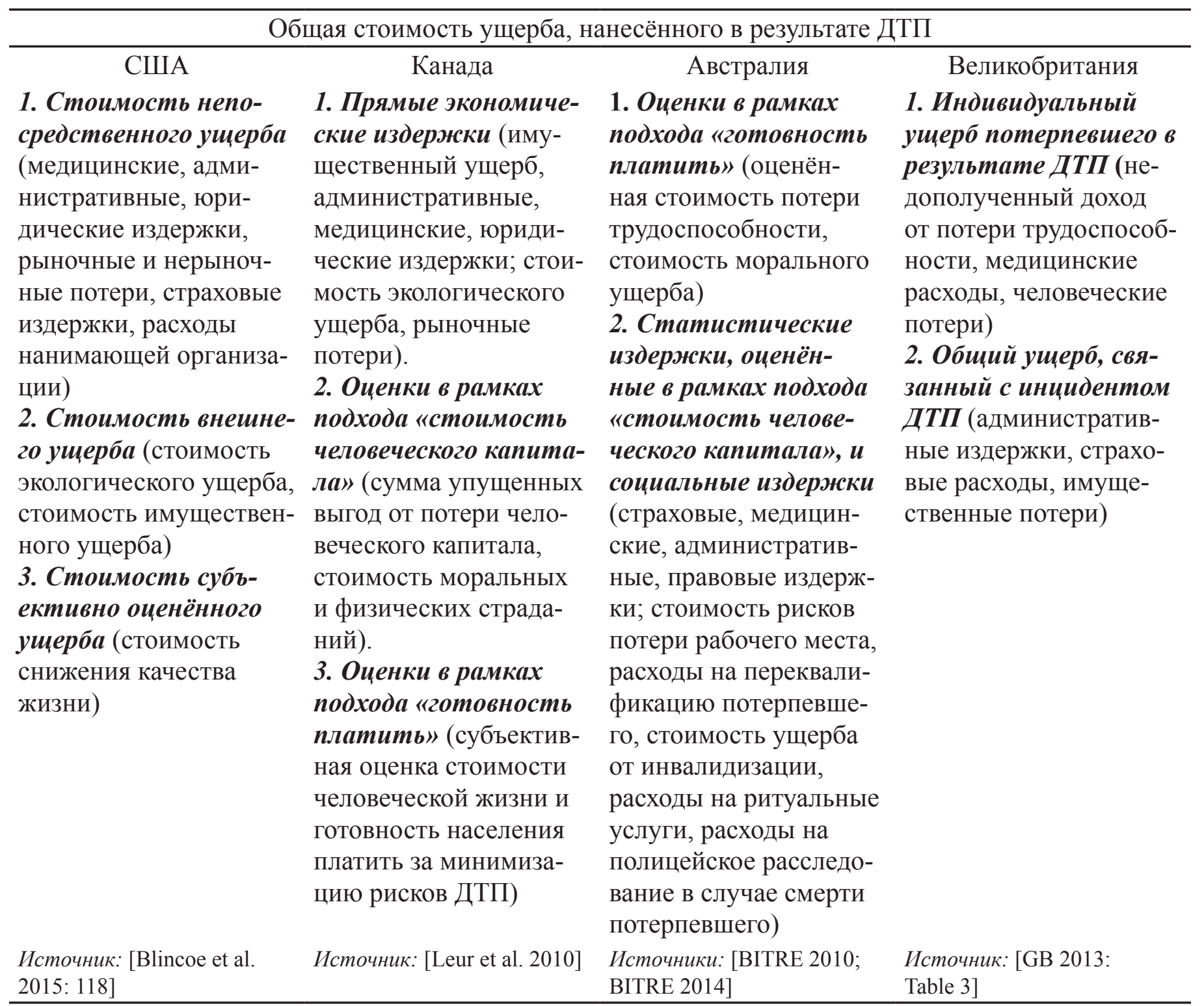

\section{Отечественные практики оценки стоимости социально-экономического ущерба от смертности населения в результате ДТП}

В Российской Федерации в начале 2000-х гг. применялась «Методика оценки и расчёта нормативов социально-экономического ущерба от дорожно-транспортных происшествий» Р 3112199 2502-00. В настоящее время действуют правила осуществления Российским союзом автостраховщиков (РСА) компенсационных выплат потерпевшим (размер которых не превышает 160 тыс. руб.), есть также подход Министерства Российской Федерации по делам гражданской обороны, чрезвычайным ситуациям и ликвидации последствий стихийных бедствий к оценке стоимости экономического ущерба, ведётся практика учёта и расчёта экономических потерь от гибели, травматизма и инвалидизации в результате аварий на производстве, практика учёта и расчёта экономических потерь от гибели в результате авиакатастроф и массовых несчастных случаев (выплаты компенсаций в случае терактов и катастроф, которые варьируются в зависимости от масштабности и огла- 
ски события), подходы частных страховых компаний к оценке стоимости экономического ущерба (в зависимости от страховой компании, страховой программы, возраста и социального статуса пострадавшего, а также от исхода ДТП). Несмотря на приведённый список, все эти методики и подходы оценки ущерба не обладают научными обоснованиями и не являются унифицированными, что не позволяет проводить сравнительные оценки величины потерь от утраты человеческой жизни даже в пределах одной страны.

Методику Р 3112199-2502-00 можно рассматривать как основной официальный документ, в котором представлен подход к оценке и расчёту социально-экономического ущерба от дорожно-транспортных происшествий в России, однако она вводилась в действие на период с 2000 по 2005 годы и утратила свою актуальность на сегодняшний день. В других нормативных документах и рекомендациях государственных и частных организаций по расчёту стоимости ущерба от ДТП единой методики не предлагается, представлены лишь зафиксированные суммы компенсационных выплат пострадавшим (например, выплаты РСА), потерпевшим с определёнными характеристиками (например, выплаты представителям определённых профессий или их родственникам) или даются оценки, которые могут варьироваться в зависимости от различных обстоятельств (например, масштабность катастрофы, величина федерального бюджета на момент катастрофы, освещённость катастрофы в СМИ и т. д.). Из-за подобной неструктурированности подходов государственных и частных организаций к определению стоимости экономического ущерба, а также из-за узкой сферы их применения в настоящем обзоре акцент будет сделан на методику Р 3112199-2502-00, являющуюся на данный момент единственным в России официальным документом, регламентирующим расчёт экономического ущерба, нанесённого гибелью в результате ДТП.

В Методике приводится расчёт (на основе оценки общих доходов) величины потерь из-за выбытия или отвлечения из сферы материального производства людей, погибших или получивших телесные повреждения. Также при расчёте стоимостной оценки ущерба в результате гибели или ранения людей учитывают затраты на оказание пострадавшим первой медицинской помощи и лечение, выплаты пенсий (инвалидам, семьям погибших), оплату по временной нетрудоспособности.

Основой этого метода является выражение в денежной форме экономической пользы, которую общество получит благодаря тому, что предотвратит гибель человека в ДТП. При таком подходе собственное потребление человека рассматривается как составная часть государственной прибыли, полученной от производственной и социально-экономической деятельности отдельных граждан. Одним из основных разделов «Методики оценки и расчёта нормативов социально-экономического ущерба от дорожно-транспортных происшествий» выступают стоимостные нормативы ущерба от ДТП по категориям пострадавших, а также предусмотренные параметры корректировки указанных нормативов в зависимости от изменения экономической ситуации в стране (индекс-дефлятор ВВП).

Методика Р 3112199-2502-00 имеет ряд существенных недостатков:

- способы оценки и расчёта социально-экономического ущерба от дорожно-транспортных происшествий по методике основываются на отечественной литературе, изданной до 1998 г;;

— отсутствие международных сравнений и используемых международных стандартов;

- отсутствие научных обоснований для использования методик расчёта социально-экономического ущерба от дорожно-транспортных происшествий;

- способы оценки и расчёта социально-экономического ущерба от дорожно-транспортных происшествий основываются на делении потерпевших в результате ДТП на категории: (1) по- 
гибшие, имевшие или не имевшие семью; (2) инвалидизированные, полностью или частично лишившиеся трудоспособности; (3) раненые, чьи потери связаны с временной нетрудоспособностью; (4) дети, погибшие в ДТП;

— не учитываются доступность статистических данных по используемым в формулах показателям;

— не учитывается региональная специфика Российской Федерации;

- не учитывается особенности подхода к анализу стоимости человеческой жизни (учитывается только недополученный ВВП на душу населения в среднем по стране);

— не учитывается половозрастная дифференциация пострадавших в результате ДТП;

— не учитываются группы инвалидности пострадавших в результате ДТП;

— не учитывается степень тяжести ранений в результате ДТП в соответствии с мировой классификацией (Международная классификация болезней 10-го пересмотра - МКБ 10);

— учитывается социально-экономический ущерб от гибели детей в результате ДТП, но не учитывается ущерб от инвалидизации и травматизма детей в результате ДТП;

— в качестве прямых потерь учитываются только ритуальные услуги.

Таким образом, возникает острая потребность в создании новой методики расчёта оценки социальноэкономического ущерба от дорожно-транспортных происшествий.

Кроме того, оценки стоимости экономического ущерба в результате потери человеческой жизни в России проводятся рядом государственных и частных организаций. В целом страховые выплаты пострадавшим в результате авиакатастроф, террористических актов и стихийных бедствий выше выплат пострадавшим в результате несчастного случая на работе или ДТП. Существуют и специальные страховые программы от несчастных случаев в целом или от ДТП в частности, где стоимость человеческой жизни и ущерб здоровью оцениваются выше.

Организациями, дающими косвенную оценку стоимости человеческой жизни, являются в основном страховые компании. В целом страховые компании предлагают разнообразные программы страхования на случай получения травмы и смерти. Важно отметить, что жизнь ребёнка в них оценивается дешевле. Потери от смерти ребёнка оцениваются ниже, чем потери от инвалидности ребёнка, так как инвалидность ребёнка предполагает большие затраты. Страховые компании не предлагают программы для страхования жизни после 65 лет. Тем не менее специальные программы по рискам смерти или инвалидности и нанесения вреда здоровью есть, но не во всех страховых компаниях. В программах по автострахованию, которые весьма распространены, учитываются характеристики автомобилей, а не водителей.

Итак, можно заключить, что в России, несмотря на то что смертности или инвалидности в результате ДТП придаётся большое значение как на государственном уровне, так и на уровне частных страховых компаний, экономический ущерб от потерь в результате ДТП существенно недооценивается. Государственные выплаты пострадавшим в результате ДТП ниже, чем в ряде других несчастных случаев. Страховые компании учитывают далеко не все экономические потери в результате ДТП. 


\section{Заключение}

На данный момент в России не существует единой научно обоснованной методики оценки экономических потерь от гибели в результате ДТП, применяемой государственными и (или) частными организациями. В 2000-2005 гг. в отечественной практике существовала «Методика оценки и расчёта нормативов социально-экономического ущерба от дорожно-транспортных происшествий» Р 3112199-2502-00. Однако подход, прописанный в данном документе, как уже отмечалось выше, имеет ряд существенных недостатков. Кратко можно подытожить, что она является устаревшей, не учитывает международного опыта, региональной специфики России и предполагает расчёт по категориям пострадавших, а не по возможным исходам ДТП.

На основе сравнения методик, рекомендуемых Еврокомиссией, Всемирной организацией здравоохранения, Организацией экономического сотрудничества и развития, с методикой Р 3112199-2502-00 были сделаны следующие выводы о применимости зарубежных методик оценки человеческой жизни к условиям Российской Федерации:

- данные о прямых потерях (количество погибших и раненых в результате ДТП, компенсационные выплаты семье пострадавшего в результате ДТП, выплаты пострадавшему пособия по инвалидности, медицинские расходы, административные расходы, страховые издержки и расходы на ритуальные услуги) учитываются международными организациями и национальными транспортными службами США, Канады, Австралии и Великобритании как показатели, включённые в общую оценку стоимости ущерба от ДТП. В России имеются статистические данные по таким переменным, и этот набор показателей можно включить в формулу расчётов;

- социально-демографические характеристики пострадавшего (возраст, пол и др.) учитываются в международной практике оценки ущерба от ДТП. В России статистические данные о возрасте и поле пострадавшего имеются и используются при расчёте общей стоимости ущерба от ДТП;

- данные, необходимые для расчётов в рамках подхода «человеческий капитал», в разной степени полноты учитываются в международной практике служб транспортной полиции США, Канады, Австралии и Великобритании. Наиболее весомый элемент оценки стоимости ущерба от потери жизни и здоровья человека в результате ДТП - заработная плата или доход пострадавшего или ВВП на душу населения - учитывается при расчёте стоимости ущерба в четырёх развитых странах. В России данные о заработной плате каждого пострадавшего не собираются, однако можно использовать данные о средней региональной заработной плате в определённом году, которые публикует Росстат, либо данные о валовом региональном продукте или о среднедушевых доходах, что делает применение подхода «человеческий капитал» возможным и в России;

- данные, необходимые для расчётов в рамках среднестатистического подхода (потребительские расходы в среднем на душу населения, ожидаемая продолжительность человеческой жизни), являются общедоступными как в развитых странах мира, так и в России;

— данные, необходимые для расчётов в рамках подхода «готовность платить», учитываются международными организациями и национальными транспортными службами США, Канады, Австралии и Великобритании. В России репрезентативные региональные опросы населения о готовности платить за повышение безопасности дорожного движения никогда не проводились, однако полезность от использования такого подхода очевидна. 
Проведённый выше анализ нормативно-правовых документов и обзор зарубежной и отечественной литературы позволяют разработать адекватный и сопоставимый с другими странами подход к оценке социально-экономического ущерба от ДТП. Так, мы предполагаем, что стоимость ущерба, нанесённого гибелью в результате ДТП, должна включать сумму стоимости прямых потерь (учитываемых в развитых странах и рассчитываемых на основе имеющихся статистических данных в России) и упущенных выгод (потеря количества средств, которые мог бы заработать индивид с определёнными характеристиками (пол, возраст) при средней продолжительности жизни в данной стране или в регионе страны). Научные подходы, наиболее применимые к оценке человеческой жизни в Российской Федерации, - среднестатистический подход (данные публикуются в открытом доступе) и подход с точки зрения человеческого капитала (в карточке ДТП учитываются пол и возраст, а Росстатом публикуются данные по заработной плате, валовому региональному продукту и среднедушевым доходам в региональном разрезе).

\section{Литература}

BO3. 2013. Доклад о состоянии безопасности дорожного движения в мире 2013. URL: www.who.int/ violence_injury_prevention/road_safety_status/2013/report/ru/

Капелюшников Р. 2012. Сколько стоит человеческий капитал России? Препринт WP3/2012/06. М.: Изд. дом ВШЭ.

Карабчук Т. C. et al. 2014. Как оценить стоимость жизни? Экономическая сочиология. 15 (1): 89-107. URL: http://ecsoc.hse.ru/data/2014/02/01/1328851429/ecsoc_t15_n1.pdf\#page=89

Огородников В. И., Брызгалова И. В. 2004. Экономическая теория. Государство и рынок. 9.4. Критерии общественного благосостояния. URL: http://www.sapanet.ru/UMM_1/2497/9_4.htm

ООН. 2010. Доклад о развитии человека. URL: http://www.un.org/ru/development/hdr/2010/hdr_2010_ technotes.pdf

Росстат. Центральная база статистических данных. Джини-коэффициент. URL: http://www.gks.ru/ $\mathrm{dbscripts/cbsd/dbinet.cgi}$

Щербакова Е. 2015. Россия: предварительные демографические итоги 2014 года (Часть II). Российский демографический барометр (рис. 19). Демоскоn Weekly. 633-634. URL: http://demoscope.ru/ weekly/2015/0633/barom04.php

Abegunde D. et. al. 2007. The Burden and Costs of Chronic Diseases in Low Income and Middle Income Countries. Lancet. 370 (9603): 1927-1938.

Abegunde D., Stanciole A. 2006. Estimation of the Economic Impact of Chronic Noncommunicable Diseases in Selected Countries. Working Paper. Geneva: World Health Organization.

Abelson P. 2003. The Value of Life and Health for Public Policy. Economic Record. 79: S2-S13.

Abelson P. 2007. Establishing a Monetary Value for Lives Saved: Issues and Controversies, Office of Best Practice Regulation. Department of Finance and Deregulation. Working papers in cost-benefit analysis WP 2008-02. URL: https://www.dpmc.gov.au/sites/default/files/publications/Working_paper_2_Peter_ Abelson.pdf 
ADB ASEAN. 2003. The Cost of Road Traffic Accidents in Brunei Darussalam. ADB ASEAN Regional Road Safety Program.

Aertsens J. et al. 2010. Commuting by Bike in Belgium, the Costs of Minor Accidents. Accident Analysis and Prevention. 42 (6): 2149-2157.

Ashenfelter O. 2006. Measuring the Value of a Statistical Life: Problems and Prospects. NBER Working Paper. № 11916.

Bahamonde-Birke F., Kunert U., Link H. 2015. The Value of a Statistical Life in a Road Safety Context — a Review of the Current Literature. Transport Reviews. 35 (4): 488-511.

Barcelo A. et al. 2003. The Cost of Diabetes in Latin America and the Caribbean. Bulletin of the World Health Organization. 81 (1): 19-27.

Becker G. 1975. Human Capital: A Theoretical and Empirical Analysis, with Special Reference to Education. 2nd ed. New York: Columbia University Press for NBER.

Bhalla K. et al. 2013. The Costs of Road Injuries in Latin America 2013. Inter-American Development Bank. IDB Road Safety Strategy INE/TSP. TECHNICAL NOTES № IDB-TN-597.

BITRE. 2010. Cost of Road Crashes in Australia. Department of Infrastructure and Regional Development, Canberra, Australia. Report 118.

BITRE. 2014. Impact of Road Trauma and Measures to Improve Outcomes. Department of Infrastructure and Regional Development, Canberra, Australia. Research Report 140. Appendix A. Economic Values for Preventing Fatalities and Hospitalized Injuries.

Blincoe L. J. et al. 2015. The Economic and Societal Impact of Motor Vehicle Crashes, 2010. Revised. Report No. DOT HS 812 013. Washington, DC: National Highway Traffic Safety Administration.

Corso P. 2006. Incidence and Lifetime Costs of Injuries in the United States. Injury Prevention. 12 (4): $212-$ 218.

European Commission. 2007. Monetary Valuation of Road Safety. URL: ec.europa.eu/transport/road_safety/ specialist/knowledge/measures/monetary_valuation_of_road_safety/index_en.htm

European Commission. 2015. Road Safety in the European Union. Trends, Statistics and Main Challenges. Mobility and Transport DG, BE-1049 Brussels.

GB. 2013. A Valuation of Road Accidents and Casualties in Great Britain: Methodology Note. Department for Transport. Road Safety. URL: https:/www.gov.uk/government/publications/road-accidents-and-safetystatistics-guidance

González J. et al. 2009. Cost-of-Illness Study of Type 2 Diabetes Mellitus in Colombia. Rev Panam Salud Publica. 26 (1). 55-63.

Hakes J. K., Viscusi W. K. 2007. Automobile Seatbelt Usage and the Value of Statistical Life. Southern Economic Journal. 73 (3): 659-676. 
Hensher D. et al. 2009. Estimating the Willingness-To-Pay and Value of Risk Reduction for Car Occupants in Road Environment. Transport Research. Part A. 43 (7): 692-707.

Hjorth K., Fosgerau M. 2011. Using Prospect Theory to Investigate the Low Value of Travel Time for Small Time Changes. Paper Submitted to the Kuhmo Nectar Conference. Oslo, Norway.

Hojman P., Ortúzar J. de D., Rizzi L. I. 2005. On the Joint Valuation of Averting Fatal Victims and Serious Injuries in Highway Accidents. Journal of Safety Research. 36: 377-386.

Horowitz J. K., Mcconnell K. E. 2003. Willingness to Accept, Willingness to Pay and the Income Effect. Journal of Economic Behavior and Organization. 51: 537-545.

Jones-Lee M., Loomes G. 1995. Scale and Context Effects in the Valuation of Transport Safety. Journal of Risk and Uncertainty. 11: 183-203.

Jones-Lee M., Spackman M. 2013. The Development of Road and Rail Transport Safety Valuation in the United Kingdom. Research in Transportation Economics. The Economics of Transportation Safety. 43 (1): 23-40. URL: faculty.wcas.northwestern.edu/ ipsavage/104-03.pdf

Kim S. et al. 2008. The Economic Burden of Cancer in Korea in 2002. European Journal of Cancer Care. 17 (2): 136-144.

Landefeld J. S., Seskin P. E. 1982. The Economic Value of Life: Linking Theory to Practice. American Journal of Public Health. 72 (6): 555-566.

Leur P. et al. 2010. Collision Cost Study. Final Report. Canada: Capital Region Intersection Safety Partnership.

Miller T. 2000. Variations between Countries in Values of Statistical Life. Journal of Transport Economics and Policy. 34 (2): 169-188.

Mishan E. J. 1971. Evaluation of Life and Limb: A Theoretical Approach. Journal of Political Economy. 794: $687-705$.

OECD IRTAD. 2014. Road Safety Annual Report: Summary. URL: http://internationaltransportforum.org/ irtadpublic/index.html

Parish R. 1991. The Valuation of Human Life. Occasional Paper. Department of Economics, Monash University. Melbourne, Australia.

Pearce D. W., Atkinson G., Mourato S. 2006. Cost-Benefit Analysis and the Environment: Recent Developments. Paris: Organization for Economic Cooperation and Development.

Pérez-Núñez R. et al. 2011. Economic Impact of Fatal and Non-Fatal Road Traffic Injuries in Guadalajara Metropolitan Area and Jalisco, Mexico. Injury Prevention. 17: 297-303.

Pitel S., Solomon R. 2013. Estimating the Number and Cost of Impairment-Related Traffic Crashes in Canada: 1999 to 2010. Western University, Canada. URL: http://madd.ca/media/docs/estimating_presence.pdf 
Richardson J. 1999. The Role of Willingness-to-Pay in Resource Allocation in a National Health Scheme. Working Paper 80. Centre for Health Program Evaluation, Monash University. Melbourne. Australia.

Shultz T. 1968. Human Capital. In: Sills D. L. (ed.) International Encyclopedia of the Social Sciences. Vol. 2. New York: Macmillan Free Press; 278-286.

Strand J. 2005. Deriving Values of Statistical Lives from Observations of Speed Limits and Driving Behaviour. Journal of Transport Economics and Policy. 39 (1): 93-108. URL: www.jstor.org/stable/2005395

Van de Kaa E. 2010. Sign-Dependent Value of Time in Stated Preference: Judgment Bias Or Exposure of Genuine Preference. European Journal of Transport and Infrastructure Research. 104: 347-367.

Viscusi W. K., Magat W. A., Huber J. 1991. Pricing Environmental Risks: Survey Assessment of Risk-Risk and Risk-Dollar Tradeoffs for Chronic Bronchitis. Journal of Environmental Economics and Management. 21: $32-51$.

Viscusi W., Aldy J. 2003. The Value of a Statistical Life: A Critical Review of Market Estimates throughout the World. NBER Working Paper. № 9487.

Wang H., He J. 2010. The Value of Statistical Life. A Contingent Investigation in China. Policy Research Working Paper 5421.

WHO Mortality Data base. URL: http://www.who.int/healthinfo/mortality_data/en/ 


\title{
PROFESSIONAL REVIEWS
}

\author{
Tatiana Karabchuk, Anita Moiseeva, Natalia Soboleva
}

\section{A Review of International and Russian Methodologies to Estimate the Economic Damage Caused by Death in the Road Accidents}

\section{KARABCHUK, Tatiana - \\ Candidate of Sciences in Sociology, Associate Professor, Department of Economic Sociology; Deputy Head, Laboratory for Comparative Social Research; Senior Research Fellow, Laboratory for Studies in Economic Sociology, National Research University Higher School of Economics. Address: 20 Myasnitskaya str., Moscow, 101000, Russian Federation.}

Email: tkarabchuk@hse.ru

MOISEEVA, Anita - MA in Sociology, Junior Research Fellow, Laboratory for Studies in Economic Sociology, National Research University Higher School of Economics. Address: 20 Myasnitskaya str., Moscow, 101000, Russian Federation.

\section{Email: aamoiseeva@hse.ru}

SOBOLEVA, Natalia - Candidate of Sciences in Sociology, Research Fellow, Laboratory for Comparative Social Research, National Research University Higher School of Economics. Address: 20 Myasnitskaya str., Moscow, 101000, Russian Federation.

Email: natsobol@gmail.com

\begin{abstract}
This article provides a review of approaches used to assess the costs of social and economic damage caused by fatalities in road accidents in Russia and other countries. The urgency of the problem is shaped by the high mortality rates of people involved in road crashes in our country compared to other countries. At the moment, absolute and relative numbers of both car accidents and fatalities in Russia are much higher than in European Union countries or in Canada and the United States. At the same time, the estimated costs of economic damage from the loss of people's lives is much lower in Russia than in those other countries. The underestimation of human life value was discussed in details in our previous publication [Karabchuk, Nikitina, Remezkova, Soboleva 2014], where we concluded that the cost of human life in Russia is equal to the value of human life in developing countries, despite the positive trend of increases in human capital in recent years in Russia [Kapelyushnikov 2012]. The social and economic consequences of the underestimation of the value of human life can have negative effects on an individual and a country: the quality of life of Russian citizens could deteriorate and the state would lose economically active population, moreover people might feel less satisfied with their lives and less happy. Thus, it is important to develop a theoretical and methodological framework for assessing the cost of deaths caused by fatal road accidents in Russia. This article raises the question of low road safety in Russia and insufficient discussion of its consequences in the scientific literature. Comparative analysis of socio-economic damage estimates in Europe and the methods to assess them will allow us a secondary methodology of evaluating the damage caused by road accidents. That in turn will help to reduce mortality rates through the implementation of road safety programs. We review international experience and compare it with current Russian methodology; after that we summarize the results of comparative analysis and provide recommendations on how to improve methods of evaluation of socioeconomic damage caused by car accidents.
\end{abstract}

Keywords: socio-economic damage; car accidents; mortality rate; value of human life; human capital; comparative analysis. 


\section{Acknowledgements}

Support from the Basic Research Program of the National Research University Higher School of Economics is gratefully acknowledged. Research findings were subsequently used for developing analytical methods applied for General Administration for Traffic Safety of the Ministry of Internal Affairs of the Russian Federation's making decisions and management in a road safety context.

\section{References}

Abegunde D., Mathers C. D., Adam T., Ortegon M., Strong K. (2007). The Burden and Costs of Chronic Diseases in Low Income and Middle Income Countries. Lancet, vol. 370, no 9603, pp. 1929-1938.

Abegunde D., Stanciole A. (2006). Estimation of the Economic Impact of Chronic Noncommunicable Diseases in Selected Countries. Working Paper, Geneva: World Health Organization.

Abelson P. (2003) The Value of Life and Health for Public Policy. Economic Record, vol. 79, pp. S2-S13.

Abelson P. (2007) Establishing a Monetary Value for Lives Saved: Issues and Controversies, Office of Best Practice Regulation. Department of Finance and Deregulation. Working papers in cost-benefit analysis WP 2008-02. Available at: https://www.dpmc.gov.au/sites/default/files/publications/Working_paper_2_ Peter_Abelson.pdf (accessed 22 November 2015).

ADB ASEAN. (2003) The Cost of Road Traffic Accidents in Brunei Darussalam. ADB ASEAN Regional Road Safety Program.

Aertsens J., de Geus B., Vandenbulcke G., Broekx S., de Nocker L., Liekens I., Mayeres I., Meeusen R., Thomas I., Torfs R., Willems H., Panis L. I. (2010). Commuting by Bike in Belgium, the Costs of Minor Accidents. Accident Analysis and Prevention, vol. 42, no 6, pp. 2149-2157.

Ashenfelter O. (2006) Measuring the Value of a Statistical Life: Problems and Prospects. NBER Working Paper. No. 11916.

Bahamonde-Birke F., Kunert U., Link H. (2015) The Value of a Statistical Life in a Road Safety Context A Review of the Current Literature. Transport Reviews, vol. 35, no 4, pp. 488-511.

Barcelo A., Aedo C., Rajpathak S., Robles S. (2003). The Cost of Diabetes in Latin America and the Caribbean. Bulletin of the World Health Organization, vol. 81, no 1, pp. 19-27.

Becker G. (1975). Human Capital: A Theoretical and Empirical Analysis, with Special Reference to Education. 2nd ed., New York: Columbia University Press for NBER.

Bhalla K., Diez-Roux E., Taddia A., De La Peña Mendoza S., Pereyra A. (2013). The Costs of Road Injuries in Latin America 2013. Inter-American Development Bank. IDB Road Safety Strategy INE/TSP. TECHNICAL NOTES № IDB-TN-597.

BITRE (2010) Cost of Road Crashes in Australia. Department of Infrastructure and Regional Development, Canberra, Australia. Report 118. 
BITRE (2014) Impact of Road Trauma and Measures to Improve Outcomes. Department of Infrastructure and Regional Development, Canberra, Australia. Research Report 140. Appendix A. Economic Values for Preventing Fatalities and Hospitalized Injuries.

Blincoe L. J., Miller T. R., Zaloshnja E., Lawrence B. A. (2015). The Economic and Societal Impact of Motor Vehicle Crashes, 2010. Revised. Report No. DOT HS 812 013, Washington, DC: National Highway Traffic Safety Administration.

Corso P. (2006). Incidence and Lifetime Costs of Injuries in the United States. Injury Prevention, vol. 12, no 4, pp. 212-218.

European Commission. (2007) Monetary Valuation of Road Safety. Available at: ec.europa.eu/transport/ road_safety/specialist/knowledge/measures/monetary_valuation_of_road_safety/index_en.htm (accessed 22 November 2015).

European Commission. (2015) Road Safety in the European Union. Trends, Statistics and Main Challenges. Mobility and Transport DG, BE-1049 Brussels.

GB. (2013) A Valuation of Road Accidents and Casualties in Great Britain: Methodology Note. Department for Transport. Road Safety. Available at: https://www.gov.uk/government/publications/road-accidentsand-safety-statistics-guidance (accessed 22 November 2015).

González J., Walker J. H, Einarson T. R. (2009). Cost-of-Illness Study of Type 2 Diabetes Mellitus in Colombia. Rev Panam Salud Publica, vol. 26, no 1, pp. 55-63.

Hakes J. K., Viscusi W. K. (2007) Automobile Seatbelt Usage and the Value of Statistical Life. Southern Economic Journal, vol. 73, no 3, pp. 659-676.

Hensher D. A., Rose J. M.,. de Ortúzar D., Rizzi L. I. (2009) Estimating the Willingness-To-Pay and Value of Risk Reduction for Car Occupants in Road Environment. Transport Research. Part A, vol. 43, no 7, pp. 692-707.

Hjorth K., Fosgerau M. (2011) Using Prospect Theory to Investigate the Low Value of Travel Time for Small Time Changes. Paper Submitted to the Kuhmo Nectar Conference. Oslo, Norway.

Hojman P., Ortúzar J. de D., Rizzi L. I. (2005) On the Joint Valuation of Averting Fatal Victims and Serious Injuries in Highway Accidents. Journal of Safety Research, no 36, pp. 377-386.

Horowitz J. K., Mcconnell K. E. (2003) Willingness to Accept, Willingness to Pay and the Income Effect. Journal of Economic Behavior and Organization, no 51, pp. 537-545.

Jones-Lee M., Loomes G. (1995) Scale and Context Effects in the Valuation of Transport Safety. Journal of Risk and Uncertainty, no 11, pp. 183-203.

Jones-Lee M., Spackman M. (2013) The Development of Road and Rail Transport Safety Valuation in the United Kingdom. Research in Transportation Economics. The Economics of Transportation Safety, vol. 43, no 1, pp. 23-40. Available at: faculty.wcas.northwestern.edu/ ipsavage/104-03.pdf (accessed 22 November 2015). 
Kapelyushnikov R. (2012) Skol'ko stoit chelovecheskiy kapital Rossii? [How Much Does Human Capital of Russia Cost?] Working Paper WP3/2012/06, Moscow: HSE Publishing House (in Russian).

Karabchuk T. S., Nikitina M. V., Remezkova V. P., Soboleva N. E. (2014) Kak otsenit' stoimost' zhizni? [How to Evaluate the Value of Human Life?] Journal of Economic Sociology = Ekonomicheskaya sotsiologiya, vol. 15, no 1, pp. 89-107. Available at: http://ecsoc.hse.ru/2014-15-1.html (accessed on 16 November 2015) (in Russian).

Kim S.-G., Hahm M.-I., Choi K.-S., Seung H.-R., Park E.-C. (2008) The Economic Burden of Cancer in Korea in 2002. European Journal of Cancer Care, vol. 17, no 2, pp. 136-144.

Landefeld J. S., Seskin P. E. (1982) The Economic Value of Life: Linking Theory to Practice. American Journal of Public Health, vol. 72, no 6, pp. 555-566.

Leur P., Thue L., Ladd B. (2010) Collision Cost Study. Final Report. Capital Intersection Safety Partnership, Canada.

Miller T. (2000). Variations between Countries in Values of Statistical Life. Journal of Transport Economics and Policy, vol. 34, no 2, pp. 169-188.

Mishan E. J. (1971) Evaluation of Life and Limb: A Theoretical Approach. Journal of Political Economy, no 794, pp. 687-705.

OECD IRTAD. (2014) Road Safety Annual Report: Summary. Available at: http://internationaltransportforum. org/irtadpublic/index.html (accessed 22 November 2015).

Ogorodnikov V., Bryzgalova I. (2004) Ekonomicheskaya teoriya. Gosudarstvo i rynok. 9.4. Kriterii obshchestvennogo blagosostoyaniya [Economic Theory. State and Market. 9.4. Social Well-Being Criteria]. Available at: http://www.sapanet.ru/UMM_1/2497/9_4.htm (accessed 22 November 2015) (in Russian).

Parish R. (1991) The Valuation of Human Life. Occasional Paper. Department of Economics, Monash University, Melbourne, Australia.

Pearce D. W., Atkinson G., Mourato S. (2006) Cost-Benefit Analysis and the Environment: Recent Developments, Paris: Organization for Economic Cooperation and Development.

Pérez-Núñez R., Avila-Burgos L., Hijar-Medina M., Celis A., Salinas-Rodriguez A. (2011). Economic Impact of Fatal and Non-Fatal Road Traffic Injuries in Guadalajara Metropolitan Area and Jalisco, Mexico. Injury Prevention, no 17, pp. 297-303.

Pitel S., Solomon R. (2013) Estimating the Number and Cost of Impairment-Related Traffic Crashes in Canada: 1999 to 2010. Western University, Canada. Available at: http://madd.ca/media/docs/estimating_presence.pdf (accessed on 21 November 2015).

Richardson J. (1999) The Role of Willingness-to-Pay in Resource Allocation in a National Health Scheme. Working Paper 80. Centre for Health Program Evaluation, Monash University, Melbourne, Australia.

Rosstat. Tsentral naya basa statisticheskikh dannykh. Gini-koeffitsient [Central Statistics Dataset. Gini Coefficient]. Available at: http://www.gks.ru/dbscripts/cbsd/dbinet.cgi (accessed 22 November 2015) (in Russian). 
Shcherbakova E. (2015) Rossiya: predvaritel'nye demographicheskie itogi 2014 goda (Chast' II) [Russia: Preliminary Demographic Results of 2014 Year (Part II)]. Demoscop Weekly, no 633-634. Available at: http:// demoscope.ru/weekly/2015/0633/barom04.php (accessed 22 November 2015) (in Russian).

Shultz T. (1968) Human Capital. International Encyclopedia of the Social Sciences. Vol. 2 (ed. D. L. Sills), New York: Macmillan Free Press, pp. 278-286.

Strand J. (2005) Deriving Values of Statistical Lives from Observations of Speed Limits and Driving Behaviour. Journal of Transport Economics and Policy, vol. 39, no 1, pp. 93-108. Available at: www.jstor.org/ stable/2005395 (accessed 22 November 2015).

UN. (2010) Doklad o razvitii cheloveka [Report on Human Development]. Available at: http://www.un.org/ru/ development/hdr/2010/hdr_2010_technotes.pdf (accessed 22 November 2015) (in Russian).

Van de Kaa E. (2010) Sign-Dependent Value of Time in Stated Preference: Judgment Bias or Exposure of Genuine Preference. European Journal of Transport and Infrastructure Research, no 104, pp. 347-367.

Viscusi W. K., Magat W. A., Huber J. (1991) Pricing Environmental Risks: Survey Assessment of Risk-Risk and Risk-Dollar Tradeoffs for Chronic Bronchitis. Journal of Environmental Economics and Management, no 21, pp. 32-51.

Viscusi W., Aldy J. (2003) The Value of a Statistical Life: A Critical Review of Market Estimates throughout the World. NBER Working Paper. No. 9487.

Wang H., He J. (2010) The Value of Statistical Life. A Contingent Investigation in China. Policy Research Working Paper 5421.

WHO (2013) Doklad o sostoyanii bezopasnosti dorozhnogo dvizheniya v mire 2013 [Global Status Report on Road Safety 2013]. Available at: www.who.int/violence_injury_prevention/road_safety_status/2013/ report/ru/ (accessed on 16 November 2015) (in Russian).

WHO Mortality Data base. Available at: http://www.who.int/healthinfo/mortality_data/en/ (accessed 22 November 2015).

Received: November 1, 2015.

Citation: Karabchuk T., Moiseeva A., Soboleva N. (2015) Issledovanie zarubezhnykh metodik i otechestvennykh praktik opredeleniya ekonomicheskogo ushcherba, nanosimogo gibel'yu v resul'tate DTP [A Review of International and Russian Methodologies to Estimate the Economic Damage Caused by Death in the Road Accidents] Journal of Economic Sociology= Ekonomicheskaya sotsiologiya, vol. 16, no 5, pp. 77101. Available at http://ecsoc.hse.ru/2015-16-5.html (in Russian). 


\section{НОВЫЕ КНИГИ}

\section{Н. В. Конрой}

\section{Где находится глобальный рынок?}

Рецензия на книгу: Çalişkan K. 2010. Market Threads: How Cotton Farmers and Traders Create a Global Commodity. Princeton; Oxford: Princeton University Press. $230 \mathrm{p}$.

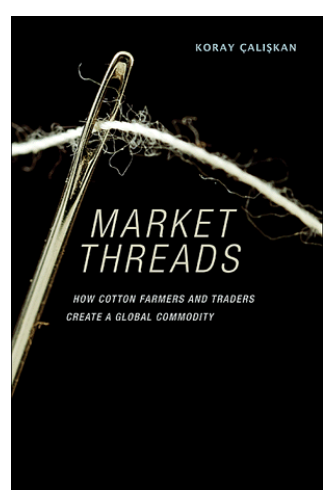

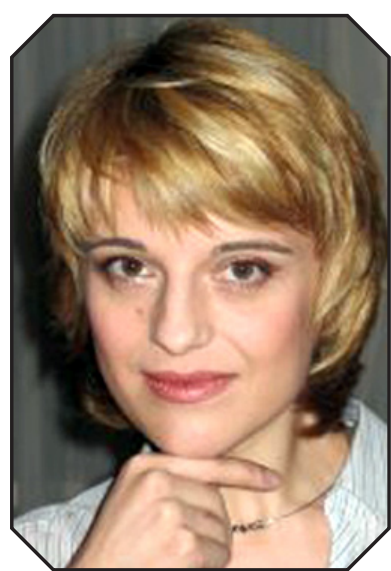

\section{КОНРОЙ Наталья}

Викторовна - кандидат исторических наук, старший преподаватель департамента социологии Национального исследовательского университета «Высшая школа экономики». Адрес: Россия, 101000, г. Москва, ул. Мясницкая, д. 20.

Email: nconroy@hse.ru
Корай Чалишкан - один из первопроходчев направления, получившего название «сочиальные исследования финансов» (Social Studies of Finance SSF). Как и его коллеги (Д. Маккензи, А. Преда, Д. Муньеса), К. Чалишкан не только живо воспринял идеи и риторику исследований науки и технологий (Science and Technology Studies - STS) и акторно-сетевой теории (Actor-Network Theory - ANT), но и вместе с М. Каллоном стал автором теоретического подхода к изучению прочессов «экономизачии» и «маркетизации». В рецензируемой книге, посвящённой глобальному рынку хлопка, исследователь утверждает, что понять рынок-значит показать, как и в каких формах на нём происходит «осуществление ценыл». Методологически рецензируемая книга представляет собой чрезвычайно интересный, хотя и противоречивый пример того, как к изучению глобальных рынков можно применить микрометоды и, в частности, «многоместную этнографию», необходимость которой в середине 1990-х г2. обосновывал антрополог Джсордж Маркус. Чалишкан, чтобы показать работу глобального рынка, проводит читателя через семь «мест», последовательно раскрывая то, как на разных уровнях агенты, опираясь на исторически и культурно обусловленные "рыночные платформы» (сочиально-технические сети, знания и деньги), производят разнье виды индикативной (протезной) и фактической ичены. «Протез» как обозначение для иены, с оглядкой на которую агенты рынка договариваются о стоимости фактических сделок, является центтральным и теоретически наиболее перспективным понятием книги, а приятным бонусом для читателя станет писательский талант автора, создавщего увлекательную, насыщенную экскурсами в историю ближневосточных неолиберальных реформ этнографию. Однако тот, кто надеется найти в книге практическое руководство по использованию «многоместной этнографии» в изучении глобальных рынков, возможно, будет немного разочарован: о работе нового метода Чалишкан задаёт больше вопросов, чем даёт ответов.

Ключевые слова: социальные исследования финансов; глобальные рынки; многоместная этнография; хлопок; Ближний Восток; история неолиберальных реформ.

\section{О чём эта книга?}

Книга «Market Threads: How Cotton Farmers and Traders Create a Global Commodity» («Нити рынка: как фермеры и торговцы хлопком создают гло- 
бальный товар») состоит из вводной, заключительной и шести основных глав, в которых представлены результаты диссертационного исследования, проведённого Кораем Чалишканом в 2000-2008 гг. в НьюЙоркском университете под руководством политолога Тимоти Митчелла (Timothy P. Mitchell). Ныне доцент (associate professor) факультета политических наук и международных отношений Босфорского университета (Boğaziçi Üniversitesi) в Стамбуле, автор книги предлагает читателю новаторский способ изучения глобальных рынков. Чтобы понять глобальное, исследователю нужно его локализовать, считает Чалишкан.

Методологический приём локализации, который он использует, - это так называемая многоместная этнография (multi-sited ethnography), одна из возможностей, позволяющих исследователю компенсировать недостаток мобильности, отличающий классическую этнографию; изучить феномены, которые нельзя понять в каком-либо одном месте; рассмотреть, как сплетаются локальное и глобальное [Marcus 1995; Candea 2009; Falzon 2009a; b]. Как может убедиться читатель, на практике выбор мест для наблюдения глобального рынка предопределяют разные факторы (например, открывшаяся возможность поучиться на курсах биржевых трейдеров в г. Мемфисс, шт. Теннесси), но связывает точки, через которые этнограф прокладывает свой маршрут, вещь - товар глобального рынка ${ }^{1}$.

С тех пор как Арджун Аппадураи ввёл понятие «социальная жизнь вещей» [Appadurai 1986], появилось множество междисциплинарных исследований, авторы которых следили за жизнью и увлекательными приключениями машин, приборов, еды, одежды и проч. Корай Чалишкан следовал - ни много ни мало! - за хлопком, заслужившим репутацию классического колониального товара, торговля которым заложила основы современного глобального мира. Согласитесь, довольно амбициозно для этнографии. Автор считает, что справился с задачей, удачно спланировав своё путешествие. Как можно ожидать от хорошей этнографии хлопка, отправной точкой стала деревня (точнее, несколько: Памуккёй в западнотурецкой провинции Айдын, Кафр-Гаффар и Избет-Сабри в Нижнем Египте 2 ), где Корай провёл три пилотных месяца в 2000 г., а затем ещё одиннадцать в полевых сезонах 2001-2002 гг., разбираясь в том, как крестьяне понимают глобальный рынок, участниками которого являются. Разговоры с фермерами привели его к трейдерам крупных портовых городов (Измир и Александрия), в общении с которыми он провёл около 40 дней, затем - на уже упомянутые курсы Американской ассоциации поставщиков хлопка в Мемфисе (май — июль 2002 г.) и, наконец, в Нью-Йоркский совет по торговле (октябрь 2012 г.). Как можно ожидать от хорошей этнографии, прежде чем превратить свои наблюдения в книгу (2008-2009 гг.), автор несколько раз возвращался в поле (2005-2008 гг.). Так что же для Корая Чалишкана оказалось главным в этом долгом хлопковом приключении?

\section{Что Корай Чалишкан говорит о глобальном рынке?}

Самой важной главой рецензируемой книги является первая, которая посвящена производству цены хлопка как глобального товара. Чалишкан видит задачу исследователя глобальных рынков в том, чтобы понять процессы, типы и формы осуществления цены (р. 22). Осуществление цены (price realization) для автора не то же самое, что ценообразование (price-setting). Оно множественно и не является «естественным» рыночным процессом, а, напротив, достигается с помощью различных инструментов торговли (trading tools), которые включают не только калькулятивные устройства, индексы, формулы, но и слухи, догадки, предположения. Автор, чтобы подчеркнуть эту искусственность, использует широкий

1 К. Чалишкан стал одним из соавторов М. Каллона и внёс значительный вклад в формулирование программы и принципов исследования процессов «экономизации» и «маркетизации» (см.: [Çalişkan, Callon 2009; 2010]). В своих недавних статьях исследователь возвращается к политической философии (см.: [Çalişkan 2015a; b]), он много времени уделяет практической политике. Но, судя по работам его аспирантов, Чалишкан не совсем оставил идею настройки качественных микрометодов на исследования глобальных рынков (см., например: [Bilbil 2012]).

2 Как можно ожидать от хорошей этнографии, все названия и имена героев вымышлены. 
каллоновский термин «протез» (prosthesis) ${ }^{3}$, конкретизируя его в понятии «протезная цена» (prosthetic price), без которой было бы невозможно формирование цены фактической сделки (actual price) (p. 23)4. Иными словами, процесс осуществления цены является локальным и приземлённым, но в него постоянно вторгаются агенты (правительства, экономисты, аналитики рынков, корпорации и др.) с более высоких уровней, на которых производятся и регулярно обновляются ценовые протезы как инструменты вовлечения локальных и региональных участников в глобальный рынок.

«Локальное» оказалось одним из самых обсуждаемых понятий в антропологии 2000-х гг., и автор книги «Market Threads...» неслучайно представляет глобальный рынок хлопка как совокупность разных типов мест (локальностей), соединённых мостиками (bridges) из человеческих и нечеловеческих (nonhuman) агентов, которые регулируют и поддерживают этот рынок. Корай Чалишкан утверждает, что в таких местах локальное встречается с глобальным; точнее, локальные агенты в каждом отдельном акте обмена действуют на разных уровнях (локальном, региональном, глобальном) и с помощью отчётов, индексов и технологий создают глобальный рынок и его особую - графическую, а не географическую (р. 18) - локальность.

Human bridges - это понятие, которое взято автором «из поля» и используется в главе 2 для описания структуры глобального рынка. Так один из его собеседников называет сети (networks) рыночных агентов. Сети, наряду со знаниями и капиталом, составляют платформу компании, а платформы компаний-участниц образуют платформу глобального рынка (market platform). Однако, по признанию топ-менеджера, без широких сетей капитал и знания бесполезны, поэтому агенты ежедневно «наводят мосты» с помощью писем, открыток, подарков и прочих знаков внимания (р. 76-80). К сожалению, автор не уточняет, соотносятся ли его представление о рынке как графической локальности и аборигенное понимание платформы рынка, но (географическая по сути) идея моста и сторон, которые он соединяет, становится для исследователя оправданием необходимости представить в своей книге точки зрения этих сторон - трейдеров и фермеров, обитающих в более или менее привычных для антрополога локальностях. Вокруг этих региональных и локальных центров торговли - городов и деревень - выстроена вторая половина книги (главы 3-6), в которой автор много места отводит голосам своих собеседников, цитируя интервью и даже поминутно описывая рутины героев.

Читатель узнаёт, что «на земле» региональные трейдеры осуществляют цены как в привычных институциональных и пространственных рамках бирж, так и вне их, и что отсутствие или наличие таких рамок не меняет сути технологий организации рынка (р. 105-106).

В Измире трейдеры делают хлопок калькулируемым и обмениваемым на бирже (Izmir Mercantile Exchange) с помощью трёх типов цены - репетиционной (rehearsal price), трансакционной (transaction price) и рыночной (market price). Каждая формируется в своём месте рынка. Первая — «внизу», в так называемой шахте (pit): в пространстве, где открываются торги и трейдеры контактируют очень близко. Вторая - на встрече Комитета по закрытию цены (Closing Price Committee Meeting), а третья — на заседании Постоянной рабочей группы по хлопку (Permanent Working Group on Cotton). Рынок здесь предстаёт и как темпорально и географически единое пространство, и как множество внутренних пространств и границ (р. 85).

3 Как мне представляется, протез для М. Каллона - это любая технология (инструмент, измерительный прибор, устройство для калькуляции), которая превращает современного человека в Ното Economicus 2.0, позволяет успешно адаптироваться и стать эффективным максимизатором своих выгод.

4 «Я определяю протезную цену как форму цены, которая производится рынком, но не используется непосредственно ни продавцом, ни покупателем в фактическом товарообмене» (р. 23-24). Так, поясняет автор, рынок хлопка ежедневно производит несколько ценовых протезов: World Price of Cotton; Adjusted World Price; A Index. Только разобравшись в том, как они создаются, можно понять рынок. В то же время только благодаря ценовым протезам продавцам и покупателям «на земле» удаётся заключать конкретные сделки. 
Репетиционная цена действует только в первые 10 минут торгов и устанавливается примерно посередине глобальной индикативной и последующей трансакционной цены. Это одновременно и региональный протез, призванный сориентировать продавцов и покупателей, и цена фактической сделки, по которой в целях демонстрации сторонами серьёзности своих намерений осуществляется небольшое число продаж. Затем стороны, опираясь на репетиционную цену ${ }^{5}$, договариваются о фактической стоимости хлопка. Позже - на встрече Комитета по закрытию цены — из перечня сделок исключаются крайние значения и с помощью математической формулы определяется рыночная цена хлопка, а Постоянная рабочая группа по хлопку на основе этих данных выносит суждение о соотношении спроса и предложения на рынке.

В Египте до создания в 1994 г. первой частной Национальной хлопковой компании (NCC National Cotton Company - NCC) торговлю хлопком осуществляли госкомпании, которые скупали сырье у крестьян через агентов агропромышленных кооперативов. В первое десятилетие неолиберальных реформ возникли больше 20 частных компаний, взаимодействие которых регулируется Александрийской ассоциацией экспортёров хлопка (ALCOTEXA), существующей ещё с колониальных времён (основана в 1932 г.). Ассоциация готовит аналитические отчёты о состоянии национального и международного рынков, выпускает газету о хлопке, осуществляет арбитраж и, самое главное, устанавливает экспортные цены и утверждает все экспортные контракты.

Каждое воскресенье до 11 утра трейдеры отправляют в ассоциацию информацию о совершённых сделках. В это время собирается управляющий комитет ассоциации, чтобы утвердить контракты и установить на следующую неделю минимальные цены для каждого вида хлопка, выращиваемого в Египте. Эти цены опираются на глобальные ценовые протезы и, в свою очередь, являются протезами для региональных трейдеров. Автор называет минимум, который устанавливает ALCOTEXA, ассоциированной ценой (associate price) (p. 111). Формально торговцы при определении цены сделки не могут опуститься ниже ассоциированной цены. Фактически в неформальных сделках они это часто делают, умело играя на противопоставлении государственного и частного, формального и неформального, рыночного и нерыночного. Кроме того, в египетском случае и ассоциированная цена, и глобальные протезы - довольно условные ориентиры для частных трейдеров и компаний, так как Египет - поставщик наиболее дорогого длинноволокнового (extralong-staple) хлопка. Торговцы регулярно следят, но не доверяют протезам и определяют цены на свой товар индивидуально, в процессе постоянных и долгих переговоров с потенциальными партнёрами (как с локальными производителями, так и с международными покупателями $)^{6}$. Государственным компаниям приходится демонстрировать большее уважение к ассоциированной цене, что, по мнению автора, однажды приведёт большинство из них к банкротству (р. 118), потому что знать людей, поддерживать связи, торговаться, быть в любое время готовым говорить о хлопке и обсуждать условия сделки - это и значит производить фактическую цену на рынке, где нет привычных институциональных рамок.

В заключительных главах книги автор показывает, как организованы производство и торговля хлопком для крестьян, вовлечённых в сложные отношения власти и переговоры с другими сторонами мостов глобального рынка, которые в деревне представлены сельскохозяйственными кооперативами и частными скупщиками. И если сельскохозяйственные кооперативы крестьяне склонны считать частью своего мира, то частные скупщики - это внешняя сила, посредники между полем и рынком, привлекающие различные ресурсы для понижения закупочной цены. В целом фермерам достаётся роль относительно

5 На мой взгляд, этот термин можно было бы русифицировать через понятие «пристрелочная цена» (как одновременно искусственная, ориентировочная, неокончательная и в то же время реальная).

6 Такой ориентацией на международные переговоры автор объяснил то, что большинство египетских собеседников отказывались давать ему интервью о хлопке на арабском и почти сразу после приветствия переходили на беглый английский. 
пассивных агентов, но в каждом «рыночном перформансе» (market performance) степень властного преимущества торговцев в осуществлении цены определяется множеством факторов (прежде всего долговой нагрузкой и размером того или иного хозяйства). По наблюдениям автора, турецкие фермеры не могут и растить хлопок, и поддерживать рынок (р. 154): выбирая хлопок, они отдают лоббистам биржи контроль над рынком. Для египетского крестьянина ситуация ещё сложнее: крупные фермеры скупают хлопок односельчан, и этот уровень рынка практически невидим для официальной статистики. Следующий уровень более прозрачен и выходит на открытые площадки - хлопковые круги (halaqas), которые организовывает и поддерживает Государственный банк развития и сельскохозяйственного кредитования (Public Bank for Development and Agricultural Credit). Хотя круги управляются и контролируются госслужащими, в закупочный сезон к каждому из них приписывается конкретный частный торговец, кооператив или конкретная госкомпания, чьи представители полный день работают на приёмке сырья, участвуя во взвешивании, определении сортности и оценке хлопка. Причём у каждой такой закупочной площадки не только свои критерии качества продукта: любой фермер знает, что «килограмм» частной компании всегда тяжелее «килограмма» государственной, а закупочная цена (target price) - ниже протезной минимальной (floor price), которая устанавливается государством как производная от ассоциированной цены на уровне выживания крестьянских хозяйств. Оружием фермеров в борьбе за лучшую цену становятся подкуп сортировщиков, гнев, крики, ожесточённый торг и, наконец, смена площадки на более далёкую от дома — наиболее эффективный, но доступный только относительно богатым фермерам приём. Большинству же приходится сдаться, поскольку частные «владельцы» кругов, в отличие от «государственных», сразу рассчитываются наличными (р. 180-185).

Сравнив измирский и александрийский рынки с тем, что он увидел в Мемфисе, понаблюдав борьбу турецких и египетских фермеров за «живые» деньги, автор утверждает, что, хотя осуществление цены в каждом случае обеспечивается очень разными, исторически обусловленными и динамичными «рыночными платформами», все рыночные цены - будь то фьючерсная цена Нью-Йоркской биржи или репетиционная, ассоциированная, закупочная цены региональных и локальных рынков - это протезы с единой логикой (р. 118, 184).

\section{Действительно ли этнография подходит для изучения глобальных рынков?}

«Market Threads...» - книга новаторская в нескольких отношениях, что одновременно и упрощает, и усложняет задачу рецензента. После долгих раздумий я решила неравно разделить ответственность с читателями и предоставить коллегам-экономсоциологам возможность судить о теоретических и эмпирических перспективах пути, прокладываемого Кораем Чалишканом между неоклассической теорией и новым институционализмом, оставив себе «побочные» эксперименты автора с методом и письмом.

Во введении к книге исследователь даёт читателю ответы на традиционные вопросы о том, почему были выбраны этот объект и такой метод для его изучения. Почему именно хлопок, удаётся объяснить быстро и убедительно; с «многоместной этнографией» всё не так однозначно. Корай Чалишкан оказался в числе первопроходцев, пытавшихся применить сформулированный Дж. Маркусом подход в поле, поэтому он сам задаёт непростые вопросы: что всё-таки означает «следовать за вещью»? как следовать за хлопком? откуда начать? в каких именно местах производства и продажи хлопка нужно делать этнографию, чтобы понять работу глобального рынка? и т. д. В результате он, по сути, отказывается от эксперимента и выбирает классический путь: «входи там, где есть дверь». Исследователь признаёт, что -

7 Марк-Энтони Фальзон неслучайно называет стиль, в котором Маркус презентовал свою модернизацию метода, телеграфным: подробных инструкций для желающих провести апробацию инструмента не прилагалось [Falzon 2009b: 1]. Корай Чалишкан же пишет: «Я начинал своё исследование, полагая, что глобальное интегрировано и укоренено в практиках агентов, которые в действительности и создают рынок [Marcus 1998]. И всё же, как очень многие перспективные подходы (fertile grounds), этот (Многоместная этнография. - H.K.) тоже довольно мутный (muddy)» (p. 14). 
в идеале - нужно рассматривать локальные и региональные рынки Китая и Индии, но практически они для него закрыты, и он утешает себя тем, что отсутствие эмпирических данных из каких-либо мест никак не сказалось бы на его теоретическом подходе (р. 15) ${ }^{8}$ Как большинство антропологов после Б. Малиновского, Корай работает везде, куда открывается доступ, в надежде продержаться подольше и собрать из более-менее случайных фрагментов сложный пазл «культуры», «общества», «рынка». Это и есть этнография, хотя почему бы и не назвать её многоместной?

В завершение не могу не поделиться с читателем тем, что в этой книге доставило мне особое удовольствие. Тот, кто когда-либо пытался разобраться, как пишут антропологи, вероятно, заметил, что авторы многих этнографий более или менее строго придерживаются «рецепта», который дал в «Аргонавтах западной части Тихого океана» отец-основатель дисциплины Б. Малиновский. Они начинают свои рассказы от «земли», описывая вещи и технологии, трудовые процессы и будни; затем переходят к людям и их отношениям по поводу вещей, технологий, труда и повседневности и, наконец, оглядывают «с высоты птичьего полёта» те «глобальные» связи (культуру, общество, рынок), которые недоступны замыленному взгляду аборигена. Корай Чалишкан тоже следует рецепту, но по-бунтарски, в обратной последовательности. Он начинает с невидимого глобального рынка (именно поэтому «самой важной» главой оказывается первая), затем проводит читателей доступным не каждому аборигену маршрутом, по которому путешествует проданный на рынке хлопок, потом отправляет нас на региональные рынки, где формируются цены сделок, и наконец, выталкивает в поле, к фермерам, к их повседневным заботам вокруг тракторов и животных, вокруг реального (глобального) хлопка. Было ли такое композиционное решение книги продуманным или интуитивным, оно идеально удерживает читателя, жаждущего понять, как же всё-таки устроен «чёрный ящик» глобального рынка. Даже тот, кто не вполне удовлетворится этнографическим объяснением загадки, закроет книгу с ощущением, что найти ответы возможно.

\section{Литература}

Митчелл Т. 2014. Углеродная демократия. Политическая власть в эпоху нефти. М.: Изд. дом «Дело» РАНХиГС.

Appadurai A. (ed.) 1986. The Social Life of Things: Commodities in Cultural Perspective. Cambridge: Cambridge University Press.

Bilbil E. T. 2012. The Politics of Uncertainty in a Global Market: The Hazelnut Exchange and its Production. Istanbul: Boğaziçi Üniversitesi; Institute for Graduate Studies in the Social Sciences. URL: https://www. academia.edu/2048962/The_Politics_of_Uncertainty_in_a_Global_Market_The_Hazelnut_Exchange_ and_its_Production.

Çalişkan K. 2015a. Explaining the End of Military Tutelage in Turkey. Submitted article. Paper presented to the Department of Political Science and International Relations Departmental Research Seminar, Boğaziçi University, February 20.

8 Конечно, аргументы, которые Чалишкан приводит в пользу выбора египетского кейса, убедительны (Египет как глобальная экспериментальная площадка проверки различных политико-экономических режимов - от колониализма до социализма Г. А. Насера, политики открытых дверей (infitah) А. Садата и неолиберальных реформ эпохи Х. Мубарака), и всё же они выглядят, как рационализация наиболее доступного этнографу поля. Не стоит забывать и о том, что Т. Митчелл, научный руководитель автора, один из крупнейших англоязычных специалистов по современной истории и политике Египта и региона в целом (см., напр.: [Митчелл 2014]). Египетские главы книги доставят истинное удовольствие читателю, интересующемуся историей неолиберальных реформ и их эффектами в агропромышленном секторе (главы 4, 6). 
Çalişkan K. 2015b. The New Political Regime of Turkey: Competitive Authoritarianism. Submitted article. Paper presented to the Department of Political Science and International Relations Departmental Research Seminar, Boğaziçi University. February 20.

Caliskan K., Callon M. 2009. Economization. Part 1: Shifting Attention from the Economy towards Processes of Economization. Economy and Society. 38 (3): 369-398.

Caliskan K., Callon M. 2010. Economization. Part 2: A Research Programme for the Study of Markets. Economy and Society. 39 (1): 1-33.

Candea M. 2009. Multi-Sited Ethnography. In: Barnard A., Spencer J. (eds). Routledge Encyclopedia of Social and Cultural Anthropology. London; New York: Routledge; 485-486.

Falzon M. A. 2009a. Introduction: Multi-Sited Ethnography: Theory, Praxis and Locality in Contemporary Research. In: Falzon M. A. (ed.) Multi-Sited Ethnography: Theory, Praxis and Locality in Contemporary Research. Farnham, Surrey, UK: Ashgate; 1-24.

Falzon M. A. (ed.) 2009b. Multi-Sited Ethnography: Theory, Praxis and Locality in Contemporary Research. Farnham, Surrey, UK: Ashgate.

Marcus G. E. 1995. Ethnography in/of the World System: The Emergence of Multi-Sited Ethnography. Annual Review of Anthropology. 24: 95-117.

Marcus G. E. 1998. Ethnography through Thick and Thin. Princeton: Princeton University Press. 


\section{NEW BOOKS}

\section{Natalia Conroy \\ Where the Global Market Is}

Book Review: Çalişkan K. (2010) Market Threads: How Cotton Farmers and Traders Create a Global Commodity, Princeton; Oxford; Princeton University Press. 230 p.

\section{CONROY, Natalia -}

Candidate of Science in

History, Senior Lecturer, Department of Sociology, National Research

University Higher School of Economics. Address:

20 Myasnitskaya str., Moscow, 101000, Russian Federation.

\section{Email: nconroy@hse.ru}

\section{Abstract}

Koray Çalişkan is among those few scholars (such as D. MacKenzie, A. Preda, D. Muniesa), to have recently conducted pioneering work in the field of social studies of finance (SSF). In his highly innovative book "Market Threads", the author presents an impressive example of how it is possible to study a global market by using micro-methods and, particularly multi-sited ethnography, which anthropologist George Marcus described in the mid-1990s as a tool for understanding phenomena that we couldn't fully grasp in just one place [Marcus 1995]. Çalişkan chose the cotton market for his study and 'followed' cotton through seven 'sites' across Turkey, Egypt and the USA. He argues that in market studies a researcher's main goal is to show how prices are realized, and he introduces a view of the global cotton market as a multiplicity of regional market platforms relying heavily on 'human bridges' (or, networks). Agents at each end of these 'bridges' routinely generate indicative prices: these are 'prosthetic devices' designed to help agents 'on the ground' and set actual prices. Çalişkan lets us see this price realization on different levels and writes an exciting ethnographic story woven from the real voices of international merchants, regional traders and local farmers. Additionally, his book provides informative reading for anyone interested in the history of neoliberal reform in the Middle East. Unfortunately though, as with any first attempt to deploy a new and 'muddy' methodological tool, the study hardly answers the question of how multi-sited ethnography itself was conducted.

Keywords: social studies of finance; global markets; multi-sited ethnography; cotton; Middle East; history of neoliberal reforms.

\section{References}

Appadurai A. (ed.) (1986) The Social Life of Things: Commodities in Cultural Perspective, Cambridge: Cambridge University Press.

Bilbil E. T. (2012) The Politics of Uncertainty in a Global Market: The Hazelnut Exchange and its Production, Istanbul: Boğaziçi Üniversitesi, Institute for Graduate Studies in the Social Sciences. Available at: https://www.academia.edu/2048962/The_Politics_of_Uncertainty_in_a_Global_Market_The_Hazelnut Exchange_and_its_Production (accessed 8 November 2015).

Çalişkan K. (2015a) Explaining the End of Military Tutelage in Turkey, submitted article, paper presented to the Department of Political Science and International Relations Departmental Research Seminar, Boğaziçi University, February 20. 
Çalişkan K. (2015b) The New Political Regime of Turkey: Competitive Authoritarianism, submitted article, paper presented to the Department of Political Science and International Relations Departmental Research Seminar, Boğaziçi University, February 20.

Caliskan K., Callon M. (2009) Economization. Part 1: Shifting Attention from the Economy towards Processes of Economization. Economy and Society, vol. 38, iss. 3, pp. 369-398.

Caliskan K., Callon M. (2010) Economization. Part 2: A Research Programme for the Study of Markets. Economy and Society, vol. 39, iss. 1, pp. 1-33.

Candea M. (2009) Multi-sited Ethnography. Routledge Encyclopedia of Social and Cultural Anthropology (eds. A. Barnard, J. Spencer), London, New York: Routledge: pp. 485-486.

Falzon M. A. (2009a) Introduction: Multi-Sited Ethnography: Theory, Praxis and Locality in Contemporary Research. Multi-Sited Ethnography: Theory, Praxis and Locality in Contemporary Research (ed. M. A. Falzon), Farnham, Surrey, UK: Ashgate, pp. 1-24.

Falzon M. A. (ed.) (2009b) Multi-Sited Ethnography: Theory, Praxis and Locality in Contemporary Research, Farnham, Surrey, UK: Ashgate.

Marcus G. E. (1995) Ethnography in/of the World System: The Emergence of Multi-Sited Ethnography. Annual Review of Anthropology, vol. 24, pp. 95-117.

Marcus G. E. (1998) Ethnography through Thick and Thin, Princeton: Princeton University Press.

Mitchell T. (2014) Uglerodnaya demokratiya. Politicheskaya vlast'v epokhu nefti [Carbon Democracy: Political Power in the Age of Oil], Moscow: Publishing House "Delo" (in Russian).

Received: Novmber 8, 2015.

Citation: Conroy N. (2015) Gde nakhoditsya global'ny rynok? Retsenziya na knigu: Çalişkan K. 2010. Market Threads: How Cotton Farmers and Traders Create a Global Commodity, Princeton: Oxford: Princeton University Press [Where the Global Market Is. Book Review: Çalişkan K. (2010) Market Threads: How Cotton Farmers and Traders Create a Global Commodity, Princeton: Oxford: Princeton University Press]. Journal of Economic Sociology= Ekonomicheskaya sotsiologiya, vol. 16, no 5, pp. 102-110. Available at http://ecsoc. hse.ru/2015-16-5.html (in Russian). 


\section{INTERVIEWS}

\section{Market Mechanism and Consumer Choice: An Interview with Sophie Dubuisson-Quellier}

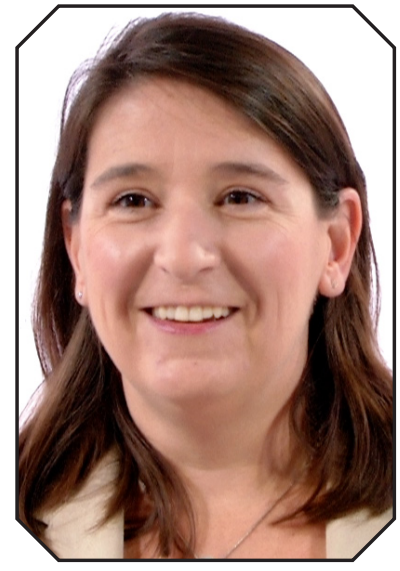

DUBUISSON-QUELLIER,

Sophie - Research

Professor at the Center

for the Sociology of

Organizations, the National

Centre for Scientific

Research (CNRS) and

Sciences Po in Paris.

Address: 19 Rue Amelie, Paris, 75007, France.

Email: s.dubuisson@cso. cnrs.fr

\section{Abstract}

The following conversation with Sophie Dubuisson-Quellier took place during the $12^{\text {th }}$ Conference of the European Sociological Association (Prague, Czech Republic, August 25-28, 2015), where Sophie chaired a session called "Food: Meals and Eating Patterns." With her colleague Gojard Séverine (French National Institute for Agricultural Research), she presented research on food waste called "Food Waste: from Household Coordination to Cooking Competencies". In her interview, Sophie shared her research interests and described her recent papers which deal with many aspects of consumer behavior. Sophie illustrates the way social movement organizations interfere in market mechanisms, reshaping the relations between producers and consumers and putting pressure on companies. She also outlined the most common social norms concerning food consumption and discussed possible sanctions for not adhering to them. Sophie describes how patterns of food consumption vary with regard to an individual's income level, socio-economic class and particular stage in the life course. Further, she clarifies the agenda of modern fair-trade organizations and their role in distribution across markets. Finally Sophie shares her views on urgent topics in modern economic sociology, as well as recommends several readings on the sociology of consumption which may be helpful for those interested in this sphere.

Keywords: sociology of consumption; social construction of markets; social movement organizations; fair-trade movement; political consumption; consumption prescriptions and food practices;

- Sophie, thank you for giving this interview. ... First of all, could you describe briefly your main research interests and how they evolved during your path as a scholar?

- Okay. My main research topic is on economic conduct. I'm trying to understand how economic conduct is framed and more specifically consumer conduct, consumer economic conduct. At first I was studying the role of firms in shaping economic conduct and consumer conduct, how some techniques such as marketing or advertising or even product design shape consumers' preferences and how this shaping may be performative into something that looks like economic conduct. And then I turned to contribution and the role of social movements and this is why I've been studying ethical consumption. Ethical consumption is an interesting topic since you can see how some movements or organizations such as environmental organizations and NGOs try to shape consumers' choices and also consumers' way of expressing themselves in the market and in the public sphere...

- And overall consumers' relations with producers of food? 
- Exactly, exactly. And more recently I have turned to the role of the state in shaping economic conduct, so I've been studying a kind of governance of economic conduct. This is basically my research topic. It is basically my research topic.

- Okay. So as I can see, your latest paper was about social movements and their contribution to market mechanisms... [Dubuisson-Quellier 2013]

— Yes, that's right.

- So maybe we can speak a little bit about that. Can you tell please what is the main agenda of modern social movement organizations, particularly in France or around the world? And how do they shape the relations between producers and consumers of food?

- Well, a lot of social movement organizations consider markets as the arena for protest. So that is because everybody is concerned about product, markets and economic activities. A market could be a very interesting way to recruit people on their side and also to put pressure on companies instead of only targeting the state. Some social movement organizations are considering that recruiting consumers could be an interesting way of targeting companies. In a way it looks like making pressure through demand by trying to change consumers' preferences. It's what is called political consumerism but it's only one way of doing it, of making that pressure, because only few people change their consumption preferences. Most of the people won't change anything though. But by doing this it also means creating some norms that diffuse to the market, what is good and what is bad. Not only changing consumption habits, it's also changing the kind of norms that influence consumption habits. So companies are really aware of this influence and some of them, even though they know that consumers won't change by having very different consumption habits. These companies know that that kind of normative pressure that they have they need to be very aware of.

- And is it more effective for the social movement organizations to refer exactly to the consumer and not to the state? Who controls the producers more efficiently?

- I'm sure that they are doing both. It's not turning to the consumer because they don't want to target the state, they still target the state by having some kind of very classical repertoire of means, but they also use that targeting of consumers, as I said, as a way of creating some context of why and how things should change on the market. And if we look at some very recent issues, such as food waste for example. I don't know how it is in Russia but I know that in UK, in Germany, in France there has been some concern from the state about food waste and this has been set on their agenda by social movements. So it's a way of targeting companies, consumers by creating a kind of general awareness of that kind of issues... And also using the market as a way of trying to solve these issues. But thus movements are also waiting some kind of change by the state.

— But why do such movements exist? What is their personal interest?

- Well, it's tough question. Why do those movements exist... I think a lot of people have lost a lot of trust in whether companies can adopt some kind of ethical practices, but they also have lost their trust in how the state could solve all these problems...

- So it is some kind of agency representation?

- Yeah, yeah, exactly. So they want to use all the different types of ways to change what the consumers consider as major issues - environmental issues or social justice issues and so on. 
— I see... And how many consumers acknowledge those social movement organizations and follow their prescriptions and admit their job overall?

— It's only few of them...

- And who are these people?

- Most of them are well-educated consumers, white people, middle-aged people, 35-45 years old. And for some of them it's not only a way of doing politics through the wallet, it's also about giving a sense to a whole part of their lives... They want to say 'when I'm a consumer, when I'm making my choice on the market, I'm also not that kind of coach potato, I want to do something and I want to be someone, so...'

- And probably they try to make the world better place for living?

- Yeah, they think they also can change the world through that kind of thing, but it's only a few people and well-educated. But it's not always people who have a lot of money. Because some of them have a high diploma, but some of them chose job with less responsibilities...

— Like some kind of downshifting?

- Yeah, yeah.

- So, that kind of people, they are self-conscious, they are environmentally-conscious... But what can all these social movement organizations do with other people, the overwhelming majority of consumers who do not know about [the movement's] job and their issues. How can they refer to them?

- Well, what I'm thinking it's not only them creating some changes in consumption; it's also about creating some kind of norms. But the problem is that those norms about ethical consumption are really middle-class norms. And we know how difficult it can be for popular class to adopt middle-class norms. Of course there is that Veblen's framework that... yeah, that it (norms) diffuses from the top, some sort of top-down diffusion. But it's not easy because a lot of people from lower classes know that these norms are not their norms and that those kind of norms are for the richer, and they are not happy to say "OK, I have to think about the environment. But who will think about my own welfare and well-being? Who is thinking about how difficult to me is to make ends meet"?

- But maybe they want to adhere to these norms but they simply have not enough income to buy, for instance, some environmentally-friendly food. But in their minds they have notion of how the relationship between consumer and producer should be?

- Yeah, and especially ethical consumption is about thinking about other people when you consume. But for a lot of people consuming is at first thinking about his or her family so it is very difficult for people to say "OK, I have to think about the environment, I have to think about the small producers in undeveloped countries, but this is too much for me, because I have my own problems and I can't solve them."

- And in your opinion, is political consumption possible without the impact of social movement organizations?

- No! I would say political consumption is about those movements. It's not about like consumers who wake up in the morning and say: "Oh, I have to be a more aware, it's all about an organization and the mobilization of people." Well, that is my point of view. ${ }^{1}$

1 See also [Dubuisson-Quellier 2015]. 


\section{— So, the thing is that consumers can't collaborate on their own?}

- It's not the individual's initiative in my point; it is a collective action that is organized by those movements.

- Ok. So, can we now refer to your next paper, which is about the role of household configuration and the life course in food consumption practices? [Plessz et al. 2014] And my question is: what are the most crucial turning points in an individual's life that affect his food consumption practices? And maybe you have some interesting examples from your own interviews?

- Yeah. Well, I would say that the most important turning point is when the first baby appears in the household. We have some terrific examples about people saying: "well, you know, when it was about us it was not a big deal, we used to go out for dinner or just have some pizza and that's it. But, now, you know, baby's here and everything have changed." So we have a lot of examples of affairs like this which means that when people turn to be parents they want to take into consideration a norm of what is a proper food for their child.

\section{— For example that it should be healthier..?}

- Yeah, healthier food. Well, it is not only about this. Proper food norms are about healthy food but they are also about having three meals a day and sitting to the table during having a meal, and sitting together and it's whole bunch of habits that people want to adhere to.

— So, the main turning point is having a first child...

- Yeah, but there are others... Also a big turning point is what demographers call an 'empty nest' - it's when the children leave the family and the parents who are retired or not are on their own now.

- And what do they start to eat?

- Well, they change their food habits because a lot of constraints disappear. They don't have to follow the dictate of what their children want to eat and everything like that. They usually describe their meal as more simple and easier to make with some salads and soups and that's it. So it's a big simplification of their meal and also all the pressure they put around that kind of activity. There is also a big turning point with some events like divorces or moving, changing job. Because you change your colleagues and the kind of prescriptions and advice you receive like "oh, you know, you shouldn't eat that or you know, I know new organic restaurant over there, it is really tasty, you should try it."

- And what are the sanctions for violating these collective norms of eating? Should you be exiled from your social group or what?

- Yeah, well, it depends, and this is why the norms about proper food and environmental norms don't function the same. For example for proper food the sanction is about being a good father or a good mother. And you can display that kind of practice to your family, colleagues, friends, making an impression like "hey, yesterday I cooked that really good meal for my child and it was really healthy and tasty." But with environmental norms you can't do so, you wouldn't say “you know, yesterday I sorted my waste” or something like that. But it simply does not work like that, because "I don't care." Even with organic it's not the same as it works within the specific community. Like, if you eat organic and I eat organic I will tell you about that new shop. But if you don't — ok, I'm not like you, I'm different, and you're not interested in that. But if I show you how good mother I am you could be interested even though you're not a mother yourself. So this is the big difference and this is why it is so difficult to spread environmental norms. 
- But maybe one day people will react on the environmental norms as they react now on you making impression of good mother? Maybe someday it will be the same reaction?

- Yeah, you right.

- OK, that's clear. And I just wanted to talk with you about one more of your papers. It is about consumers' involvement in fair-trade movements [Dubuisson-Quellier, Lamine 2008]. Can you describe briefly what the fair-trade movements are, what is their agenda and how the consumers are being involved in their actions?

- Well, at the beginning the fair-trade movement at least in France was organized by some organizations from the development sector. And their goal was to help people in Southern countries to develop. And then some part of these movements had this idea of using the market "maybe we could mobilize consumers from the North and if they help producers from the South by paying a surplus for the product - that could help those people." So this is why they decided to address consumers. But part of the development movement is really against that because most of them were criticizing the global market for the global commodities like coffee and tea and sugar and cotton. And they said that well, you cannot criticize the market and use the market at the same time - it's kind of strange way of doing things... But the fair-trade movement organized that way and it became very popular even though only few were buying fair-trade products. It became very popular and mostly because in some countries the state was pushing towards that kind of actions. But with the crisis 2008, most of fair trade sales have decreased, at least in France. This is the case with organic food.

- But are all these fair-trade organizations about small local business, or large companies are involved in it too?

- Well yes, because there are at least two models, business models for organizing fair-trade. In one of them it's about selling a kind of label, so companies can pay royalties to use the label and so it means organizing the fair-trade supply chain by selling more and more products. So it could be different from the another way of organizing supply chain, which is by allowing only specific actors to be fair-trade actors.

\section{— As I guess, all that fair-trade products are popular only among particular group of consumers?}

- Yeah. And this is the main difference between consuming organic and consuming fair-trade. Consuming organic could be and for most people it's the case - it's for half reasons that people consume organic products even though there is no health prescriptions - it's just about the environment and they think that it is good for their health. So this is why the consumer buys organic products. But consuming fair-trade is all about thinking about producers from the South.

- Okay. And now I have few more questions. How do you think, what are the main issues and urgent topics of modern economic sociology on the whole, and particularly of sociology of food consumption as your professional interest?

- Speaking about the major issues in economic sociology which are not related to food consumption. I would say all the issues about financialization are really important. And all the issues about morals and markets, and commodification in my point of view. And also I would say coming back to the role of the state is also very interesting topic to analyze. For me, the food question is just a topic that can lead you to examine broader questions such as the role of the state and 'the moral.' Also all the questions of finance too, because there are some credit issues concerning consumption that you can also study. 


\section{— And what project will you present here, at the ESA $2015^{2}$ ?}

- Well, tomorrow I'm presenting a paper on household food waste. So, yeah this is a recent topic that has been as I said addressed by a lot of governments. And most of them are addressing this topic as individualresponsibility topic - it's like people are responsible for that. So I with my coauthor Gojard Severine, we want to show that it's a broader issue and a lot of this practices about waste are about how people frame their consumption habits and how these practices are framed by norms. And especially in the case of food waste people are influenced both by norms that tell them to have a lot of food and some surplus. And some norms tell them to throw it away and other norms tell them not to throw away. And in the middle there are these safetyfood prescriptions that tells you "oh, you shouldn't keep that yogurt which is out of date, so throw it away." Or another norm that tells you, you know, you should always have at home some food, like if the friend shows up you should be able to welcome him or her and make him or her meal. So you have to have something in your fridge. But it turns out that nobody showed, so what are you going to do with that food? And all the norms of the proper meal that tell you that for your family you should have a lot of fruits and vegetables and fresh products to cook fresh meals. But you don't know if you will you use them, and it happens that you did not and you have to throw them away.

- But where do these norms come from? About what you should do with the food waste? I mean are there some kind of organizations that tell you what should you do?

- Well, there are plenty of them (norms) and as I said they are very different. Some come from nutrition professionals, others come from the environmental groups and also governments are involved. During the 1980s there were said a lot like "you should follow the expiration date it is really important because you could be poisoned." And now a lot of governments are saying "oh, maybe those expiration dates are not so good, they are too short and actually it's not a big deal if your yogurt is out of date for one or two weeks." So there are a lot of prescriptions everywhere and people are a bit lost about that. And also in this paper we are demonstrating that people do not have the same habits regarding the type of food. For example, for fruits and vegetables they are not the same as for already cooked food. And they do not do the same for food with an expiration date. So you can't set some kind of unique prescription, also you have to cross all those with all the different social positions so it's very complex issue.

- I see. And what theoretical approaches do you use when you explore all these kind of relationships between the consumer and producer, or in this topic of food waste? What are the most applicable ones?

- Well, it's in this work where I'm not using a lot of economic-sociological concepts, not so much. Except maybe the concept of prescriptions, we use it a lot in French economic sociology. It allows us to identify the role of all the "equipment" that people have around them to make their choice and their decisions. And some of this equipment comes from the market, some comes from the government and some comes from social movements. I'm also using the concept of symbolic boundary - which doesn't come from economic sociology at all but comes from cultural sociology. But it shows that some people also want to adopt norms from the groups they think they belong to and not from other ones. So regarding food waste, some people can be really, really reluctant to adopt those kind of prescriptions, they associate them with you know that kind of people, very environmentally-concerned and they don't want to be associated with them. Especially in France.

\section{— Ok. So two last small questions left. What was the last book you've read?}

- Well, I read a lot this summer. I read a book by Steiner Philippe and Trespeuch Marie which is called Marchés contestés. Quand le marché rencontre la morale [Steiner, Trespeuch 2014]. This book is about the

$2 \quad 12^{\text {th }}$ Conference of the European Sociological Association 2015. 
conditions through which a market can develop and function despite the moral opposition it might raise. So "contested markets" are not against morals, on the opposite the authors show how they connect different orders of the moral. Excellent book. And now I'm reading at the time Food Waste by David Evans [Evans 2014]. It's a short but really good book. David Evans is the big specialist of food waste. He is from Manchester University.

— And what is his main point in his book?

- Well he is explaining how people are making some surplus when they provision food and how this surplus can become excess and then waste. So it's the circuit of the food - from food to surplus and then excess and then waste.

- So that's all. It was a pleasure to meet you and have conversation with you. Thank you very much!

— Thank you!

\section{Interviewed by Kirill Makarov August 2015, Prague}

\section{References}

Dubuisson-Quellier S. (2013) A Market Mediation Strategy: How Social Movements Seek to Change Firms' Practices by Promoting New Principles of Product Valuation. Organization Studies, vol. 34, no 5-6, pp. 683-703.

Dubuisson-Quellier S. (2015) From Targets to Recruits: The Status of Consumers within the Political Consumption Movement. International Journal of Consumer Studies, no 39, pp. 404-412.

Dubuisson-Quellier S., Lamine C. (2008) Consumer Involvement in Fair Trade and Local food Systems: Delegation and Empowerment Regimes. GeoJournal, vol. 73, no 1, pp. 55-65.

Evans D. (2014) Food Waste: Home Consumption, Material Culture and Everyday Life, London: Bloomsbury Publishing.

Plessz M., Dubuisson-Quellier S., Gojard S., Barrey S. (2014) How Consumption Prescriptions Affect Food Practices: Assessing the Roles of Household Resources and Life-Course Events. Journal of Consumer Culture, pp. 1-23. Published online before print, doi:10.1177/1469540514521077.

Steiner P., Trespeuch M (eds) (2014) Marchés contestés: quand le marché rencontre la morale [Contested Markets: When the Market Meets the Morale], Toulouse: Presses universitaires du Mirail-Toulouse (in French).

Received: September 16, 2015.

Citation: Market Mechanism and Consumer Choice: An Interview with Sophie Dubuisson-Quellier. Journal of Economic Sociology = Ekonomicheskaya sotsiologiya, vol. 16, no 5, pp. 111-117. Available at http://ecsoc. hse.ru/2015-16-5.html 


\section{NEW TEXTS}

Ivan Zabaev, Anna Zueva, Yuliya Koloshenko

\section{Humility and The Gift: The Elective Affinity of Institutions and Ethics in Orthodox Parishes}

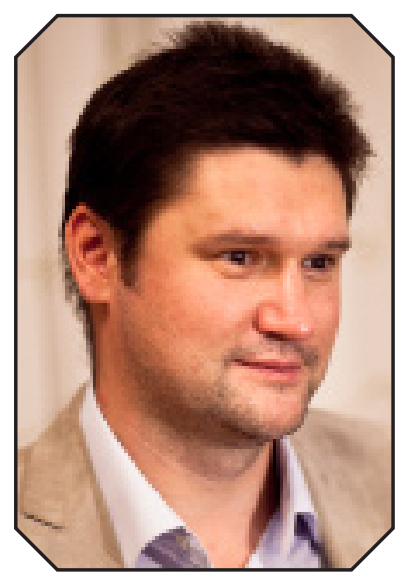

ZABAEV, Ivan -

Ph.D. in Sociology,

St. Tikhon's University,

Faculty of Theology,

Associate Professor,

Scientific Advisor at the

"Sociology of Religion"

Research Seminar;

St. Tikhon's Orthodox

University. Address: 23B,

Novokuznetskaya str.,

Moscow, 115184, Russian

Federation.

Email: zabaev-iv@

yandex.ru

\begin{abstract}
This article analyzes the economic ethics of modern Orthodox laity belonging to the Russian Orthodox Church. The article is based on an array of interviews with priests, and Orthodox laypersons (as well as non-believers and Catholics for comparison purposes). Data were collected via several projects from 2004 to 2014. Data (in-depth interviews from the recent projects 2012-2014 amount to 395) are analyzed by means of the grounded theory methods, including substantial and theoretical coding, theoretical sampling, and constant comparative method. Theories used include the concept of elective affinity between the motivation of economic activities and types of economic organization (Weber) and the typology of economic systems by K. Polanyi.
\end{abstract}

This study attempts to show the elective affinity between the ethics of humility and the principle of economic integration known as reciprocity networks of mutual support of both churched and unchurched Russians, centered in the parishes and functioning on the basis of the logic of gift giving. Such a coupling of motivation and informal economy, invisible to the GDP, performs important functions in contemporary Russia which has a mix of economic types (such as generating of social capital or development of moral density and solidarity in local communities. They in it's turn fulfill some economic functions - i.e. avoiding getting into the debt bondage or some others). The article deals with (the activated by humility ethics) reciprocity and its consequences for the community seeks to challenge the established view on Orthodox Christianity as an 'unproductive' culture, hindering economic development.

Keywords: economic ethics; Orthodox Christianity; gift; humility; Max Weber; Karl Polanyi.

\section{Introduction}

At the beginning of the 20th century, Max Weber [Weber 1990] and Ernst Troeltsch [Troeltsch 1912] reformulated the question ${ }^{1}$ of the relationship between religion and the economy to illustrate that the development of certain types of Protestantism fostered the development of capitalism and economic development. By the 1950s-1960s, the link between capitalism and development was firmly established in the social sciences, particularly, in economics [Rostow 1960]. In brief, the idea was that the development of the free market promoted the economic growth of a country (measured by GDP which is up to this point often perceived as 'welfare' index, though not designed for this purpose). It was also argued that independent individuals, equipped with values of self-realization and calculative rationality,

\footnotetext{
For the history of the problem prior to Max Weber, see [Münch 1993].
} 


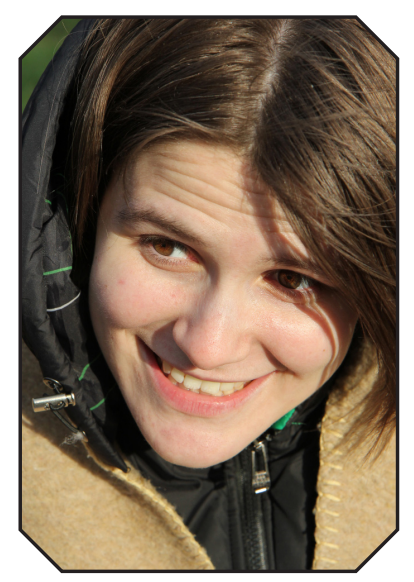

ZUEVA, Anna - Bachelor in Sociology, Research Fellow at the "Sociology of Religion" Seminar;

St. Tikhon's Orthodox University. Address: 23B, Novokuznetskaya str., Moscow, 115184, Russian Federation.

Email: annazueva.vl@ gmail.com

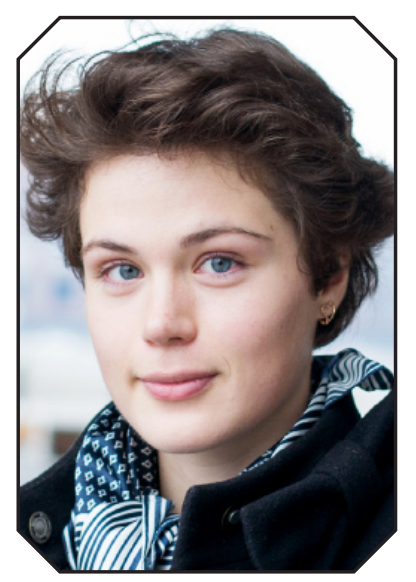

KOLOSHENKO, Yuliya - Bachelor in Sociology, Research Fellow at the "Sociology of Religion" Seminar; St. Tikhon's Orthodox University. Address: 23B, Novokuznetskaya str., Moscow, 115184, Russian Federation.

Email: ykoloshenko@ gmail.com and maximizing their utility would promote the economic development of the country in the best possible way. Both theoreticians and empiricists, the supporters of liberalism, conducted a number of studies intended to identify the set of factors which boost progress and development ${ }^{2}$. Culture, and religion as its most important component, was recognized as one of the most important factors [Harrison, Huntington 2000]. By exploring connections between religion and economic development, modern scholars often emphasize different parts of development such as trust level, different economic values (market preference, competition and so on). In the most cases of Christian denominations researchers turn to only two - Protestants and Catholics. In this case Protestantism best promoted development (for example, [Putnam, Leonardi, Nanetti 1993; La Porta et al. 1997]). If we add other denominations or religions (Islam, for instance), we may see similarity between Catholicism and Protestantism (see, for example, [Guiso, Sapienza, Zingales 2003; Lehrer 2004]). Orthodoxy has been equated with cultures which do not foster economic development (see, for example, [Snegovaya 2011 on the basis of Grondona 2000]). Proponents of liberalism suggest that unproductive values and cultures should be reformed and changed on productive ones [Yasin 2003].

In this situation, in order to be able to evaluate the potential costs of such reforms, the problem is to describe the motives and actions of the Orthodox laity in economic life, to conceptualize this behavior in respect to the problems of productivity, and to confirm the hypothesis whether Orthodox economic activity in modern conditions can be presented as potentially productive in the context of the available typologies of economic life.

This article first presents the theoretical foundations of this study in the works of Max Weber and Karl Polanyi. Next, we describe the stages of theoretical sampling and qualitative data collection, on which this article is based. Third, we provide evidence from interviews of the vocabulary of motives, that of 'humility,' as observed in Russian Orthodox laity. The conclusion suggests economic consequences of this motive and related activities.

2 The danger of interpretation of GDP growth as social progress has been emphasized by many outstanding economists since 1960s (among these Simon Kuznets, Hicks, Samuelson, Nordhaus and Tobin) [Van den Bergh 2009: 118]. Van den Bergh systematized a large number of well-founded criticism aimed at this misuse of GDP. To name a few, GDP omits nonmarket transactions (while the latter may be crucial for survival in unfavourable economic conditions), while highlighting average income, it ignores the income distribution and the happiness studies showed little correlation between the happiness and GDP (the growth of GDP being sometimes in inverse correlation with happiness).

In Russia, the GDP is still given special attention, meaning the neglect of reciprocity in the context of social relations and economic policies. What is more, GDP increases when reciprocity is replaced by the anonymous arm's length relationship [Fleurbaey 2009]. When addressing modern Russia, authors tend to mention the low efficiency of formal institutions, while compensating by the development of informal ones requiring social capital, social network involvement, and trust. This is not reflected in the GDP, and may be considered as insignificant due to the substitution of the concepts of GDP and social welfare. The politics of strengthening relations of reciprocity is actually contrary to the widely accepted goal of increasing GDP. Because of this, as will be shown in the article, this widely shared scientific and political misuse of the GDP may have great implications for the actual development, especially in small towns. 


\section{Theoretical Foundations of the Study}

\section{Weberian Framework}

One of the basic premises of this study is the premise Max Weber tried to justify in The Protestant Ethic [Weber 1990], namely, the functioning of a specific economic system requires a specific motivation ('form of capitalism' has an elective affinity with the 'spirit of capitalism') and without such motivation an economic system cannot emerge. It is the dominant form of culture (at the time when Max Weber was writing his work) that defines the vocabularies of motive for the subjects of economy. This premise of Weber is used today (or was used in the recent past) by such different authors as Harrison and Huntington [Harrison, Huntington 2000], Inglehart and Welzel [Inglehart, Welzel 2011], Hofstede [Hofstede 2002], Schwartz [Schwartz 2008], Triandis [Triandis 2007], DiMaggio and Powell [DiMaggio, Powell , 2010] and others. Detailed reviews of research on the influence of culture on economy and religion can be found in Wuthnow [Wuthnow 2005] and Iannaccone [Iannaccone 1990, 1998].

We should move on directly to Weber's constructions. Three of Weber's ideas will be important for our analysis of economic ethics of Orthodox laity:

1. Economic ethics / motivation,

2. Elective affinity (Wahlverwandtschaften).

At the time of Weber's research, the notion of ethics was associated with individual action, aimed at one or another object or situation (belonging to the world). This action made it possible to achieve the ultimate transcendent good or at least corresponded to it [Albrow 1990].

In the The Protestant Ethic, Weber actually used the concept of 'ethics' relatively rarely and never provided its consistent elaboration. In fact, only once did he treat it in some detail. In this passage Weber distinguished ethics from doctrine and practice [Weber 1990: 137-138]. On the basis of this threefold division, Weber described the Calvinist doctrine of pre-election to salvation, examining the "Westminster Confession" of 1647, and then raises a problem which is the problem of religious Christian ethics. For Weber's Protestant, the question of ethics is formulated as follows, "Am I elected to salvation or not." Having described the Protestant ethics and the specific version of the Reformed answer to the question, "How can I be saved," Weber went on to describe the economic ethics of Protestantism. This description is mainly contained in the chapter, Asceticism and the Spirit of Capitalism [Weber 1990: 184-208]. In order to understand the meaning of economic ethics in Weber's understanding and what is its basic question, we should turn to the quotations from that chapter of The Protestant Ethic:

Unwillingness to work is symptomatic of the lack of grace. $<\ldots>$ For everyone without exception God's Providence has prepared a calling, which he should profess and in which he should labor. $<$...> It is true that the usefulness of a calling, and thus its favor in the sight of God, is measured primarily in moral terms, and thus in terms of the importance of the goods produced in it for the community. But a further, and, above all, in practice the most important criterion is found in private profitableness. For if that God... shows one of His elect a chance of profit, he must do it with a purpose. Hence the faithful Christian must follow the call by taking advantage of the opportunity [Weber 1990: 188-190].

Considering the above fragments, the basic question of economic ethics can be formulated in the following way: "How do my economic activities (operate in the world) demonstrate to myself and others that I am among 
the elect in order to be saved?" 3 The answer to this question should indicate the mode of action, which would include a validation procedure of what the person is doing and what happens to him in terms of salvation.

Thus, the economic ethics of a soteriological religion should include the answers to the question of how they should act in the world in order to be saved. Yet there is another difficulty in the fact that the answers of religious actors to fundamental questions concerning the meaning of economic activities in Christian Orthodoxy may differ from the principles guiding those same actors in their daily economic practices or activities. Therefore, it is desirable to carry out a separate analysis of the 'declared' and 'actual' economic ethics manifested in their practices.

One of the main lines of criticism aimed at Weber's theses in The Protestant Ethic was that one should ascribe the idea of 'calling' to Protestantism, since the written documents on economy, such as the statements of Luther and Calvin concerning work and interest, contained very different prescriptions, judging both by specific instructions and by the general tone of the documents [Samuelson 1964; Robertson 1933]. However, Weber indeed claimed that the emergence of a particular capitalist ethos was triggered not by direct instructions regarding economic activities, but by general instructions on the path of salvation [Weber 1990]. To analyze the direction in which ethics could influence economy, instead of speaking about causality, Weber used the notion of elective affinity. Weber took his idea of elective affinity from Goethe, who in turn borrowed from the chemists of the seventeenth-eighteenth centuries [Howe 1978: 373-74]. This idea claimed that just as two elements do not always react and form some new substance, not all ethics would join one or the other organizational form or 'types of life orders.' In The Protestant Ethic, Weber showed that in order for an economic boom to occur, the organizational forms of capitalism (which existed in many places and over a long time) had to appear in a position of elective affinity with particular economic ethics. Richard Howe interpreted the concept of Weber in the following way: "Where the judgments constituting two or more of its terms intersect, a transition point between the terms is defined. Where two or more of those terms share a predicate in common, they are in that respect 'adequate' to one another, or, in the sense of Mellin's table of conceptual affinities and Kant's idea of reason before it, they possess inner affinity" [Howe 1978: 379]. According to Howe, all Weber's typologies are built upon this principle. In other words, in order to speak of 'causality,' it is necessary to look for the intersecting elements in the various patterns which describe, for example, a typical motivation of economic activities and the typical structure of its organization.

\section{Types of Society / Economy Organization. Elective Affinity between Ethics and Types of Social Organizations}

One of the widely accepted typologies of the connection between the organization of the economy and society was offered by Karl Polanyi. In his works Polanyi, following the institutional logic in analysys of economies ${ }^{4}$ [Polanyi 1977], distinguished between the formal and substantive approach to economy, and insisted that the formal approach is in fact the acceptance of one of the three forms of economy formed in the course of history, identification of its organizational structure, and treatment of the structure as theoretical, normative, and timeless, ignoring the set of conditions which caused it. Defining and distinguishing economics, Polanyi suggested a typology which takes into account its major factor, 'the form of integrating' the movements of the elements in the economic process (goods, labor, logistics, etc.):

...it is suggested here that economies be grouped according to the form of integration dominant in each of them. Integration is present in the economic process to the extent that those movements of

3 Instead of the notion of "pursuing economic activities," Weber already uses a concrete notion of 'professional calling.'

$4 \quad$ In the framework of polanyian approach "Institutions have to be understood as socially constructed entities in which economic processes are culturally codified in such a way that the fluidity inherent in economic movements acquires stability. This involves understanding the specificity of the culture of the market where it is present" [Moucourant, Plociniczak 2013: 514]. 
goods and persons which overcome the effect of space, time, and occupational differentials are institutionalized so as to create interdependence among the movements. ...Forms of integration thus designate the institutionalized movements through which the elements of the economic process - from material resources and labor to the transportation, storage, and distribution of goods - are connected [Polanyi 1977: 35].

Polanyi identifies three such principles of integration — redistribution, reciprocity, and exchange. ${ }^{5}$ His definition of the three types of economies as forms of integration is as follows:

As a form of integration, reciprocity describes the movement of goods and services (or the disposal over them) between corresponding points of a symmetrical arrangement; redistribution stands for a movement towards a center and out of it again, whether the objects are physically moved or only the disposition over them is shifted; and exchange represents a movement in a similar sense, but this time between any two dispersed or random points in the system [Polanyi 1977: 36].

Polanyi pointed out that it was necessary to distinguish between personal attitudes, supporting structures, and forms of integration. He wrote that the emergence of a certain form of integration does not depend on one or another type of personal attitude, and until specific institutions were in place which would support a certain type of integration, this form would not reach wide distribution. We may assume that Polanyi would agree with Weber's idea of affinity between personal attitudes and the supporting structure, as seen in the following idea of Polanyi: "They certainly also denote definite kinds of personal attitudes and actions, those of mutuality and barter; but diffuse individual acts of mutuality or barter lack the essentials of effectiveness and continuity on the societal plane" [Polanyi 1977: 37]. It can be assumed that if this affinity was not there, we would not be able to speak about any "definite kinds of personal attitudes and actions," since they would be distributed in a random way.

As a summary, we can present a table, comparing the main types of the economy as they are introduced by Polanyi (Table 1). Due to the fact that the approach of Polanyi has gained wide popularity, many authors have made an additional comparison of the three forms of integration, identified by him. Some of these developments are also included in the Table 1.

Thus, our goal in this study can be reformulated as the search for a common element in a certain type of economy (form of integration), and a typical motivation (personal attitude) manifested by Orthodox Christian actors. We may assume that all three types of forms of integration can be seen in Russia today. It is difficult to say which of them is dominant; probably in different areas of life and/or in different areas of Russia one would see the dominance of different forms. ${ }^{6}$ Therefore, the following discussion will concentrate on (1) the vocabulary of motives among Orthodox actors, in other words, an Orthodox ethics of economic actions, and (2) the search for a common element in the motivation logics and patterns of economic actions.

5 Incidentally, these three types of economies are also three types of solutions for the Hobbesian problem of social sciences the answer to the question of how society is possible? Hobbes' own answer is rather the 'hierarchy / redistribution' kind [Hobbes 2001] Cf. another version of this same tradition [Graeber 2015], liberal-economic answer [Smith, Nicholson 1887; Akerlof 1994; Hayek 2005; Shelling 1956], and the answer based on the notion of gift exchange [Mauss 1996; Sahlins 1972 : 157-169].

6 We may assume the direction of the Orthodox engagement into the economy/social life of Russia, if (and only if) we will be able to confirm the elective affinity between form and spirit (the personal attitude). This assumption in turn is based on the idea of Troeltsch that certain versions of Christian sets of doctrines already entail the main types of social organization for the denomination which follows them [Troeltsch 1912]. In other words, the set of doctrines of a denomination considers some types of personal attitudes and supporting structures acceptable, while others - not so. It should not be understood in the sense that the denomination prohibits something (see Weber's argument in the controversy with the anticritics [Münch 1993]), but in the sense that it simply cannot perceive some things at all, and therefore cannot consider them significant. 
Table 1

Comparison between the Main Types of Economies

\begin{tabular}{|c|c|c|c|c|}
\hline Author & Indicator & Compared Types & Key Notion & $\begin{array}{c}\text { Nature of } \\
\text { Correlation }\end{array}$ \\
\hline \multirow[t]{3}{*}{ Polanyi [1977] } & Form of integration & redistribution & exchange & reciprocity \\
\hline & supporting structure & centricity & market & symmetry \\
\hline & personal attitude & cooperation & barter & mutuality \\
\hline $\begin{array}{l}\text { Thompson, } \\
\text { Frances et al. } \\
{[1991]}\end{array}$ & $\begin{array}{l}\text { Means of collective ac- } \\
\text { tion in society }\end{array}$ & hierarchies & markets & networks \\
\hline Gough [1994] & $\begin{array}{l}\text { Taxonomies of eco- } \\
\text { nomic systems operat- } \\
\text { ing as }\end{array}$ & state & market & community \\
\hline Ostrom [1990] & $\begin{array}{l}\text { Organizational forms } \\
\text { which enable collective } \\
\text { action in these contexts }\end{array}$ & state & $\begin{array}{l}\text { private sec- } \\
\text { tor firm }\end{array}$ & $\begin{array}{l}\text { voluntary } \\
\text { co-operative } \\
\text { associations }\end{array}$ \\
\hline \multirow[t]{3}{*}{$\begin{array}{l}\text { Barsukova } \\
{[2004]}\end{array}$} & $\begin{array}{l}\text { Type of social relation- } \\
\text { ships }\end{array}$ & patron-client relationship & $\begin{array}{l}\text { commodity } \\
\text { exchange }\end{array}$ & reciprocity \\
\hline & Status of the good & tribute & commodity & gift \\
\hline & aim & $\begin{array}{l}\text { receiving additional benefits from } \\
\text { the position in the hierarchy }\end{array}$ & $\begin{array}{l}\text { profit maxi- } \\
\text { mization }\end{array}$ & $\begin{array}{l}\text { collective } \\
\text { survival }\end{array}$ \\
\hline
\end{tabular}

\section{Research Methodology. Data Description. Theoretical Sampling}

Based on the theoretical context of the Weberian approach and the conceptual framework of substantivist anthropology [Polanyi 1977; Sahlins 1972], combined with our previous empirical work analyzing the Orthodox community from 2004-2012, we constructed the following project design. We use theoretical sampling as enumerated in grounded theory [Glaser 1978; Strauss, Corbin 2001; Morse 2000, 2010].

This study comprised research in several stages, all of which were guided by three major themes:

1. Orthodox parish community and social work of the Church.

2. Economic ethics and motivations of Orthodox laity.

3. The role of debt and the elective affinity between ethics and actions.

These three themes represent the logical continuation of the work which began in 2004. Our research was aimed at analyzing economic ethics, actualized in the practices of the communities which emerged around the monasteries of the Russian Orthodox Church [Zabaev 2012]. The earlier study from 2004-2006 resulted in the description of the categories of obedience, humility and blessing which in our opinion are the core categories of Orthodox ethics manifested in the practices of modern Orthodox actors ${ }^{7}$ [Zabaev 2015]. An additional outcome of this project was understanding the distinction between the categories of ethics which were manifested in the practices of monks, novices, and lay people who were in contact with monasteries, and the categories of economic ideology which surface in the texts of economic doctrines, as well as pastoral and popular Orthodox literature. The ideology forms around the categories of 'helping your neighbor,' 'self-sufficiency,' 'good morals,' etc.

7 Elaboration of this argument (and polemics over it) can be seen in the following studies [Chirkov, Knorre 2015; Knorre 2014; Rousselet 2013; Khudyakova, Pepelyaeva 2013; Dubovka 2015; Medvedeva 2015; Kiselev 2014; Titaev 2013; Titkov 2012]. 
Accordingly, at the beginning of our project on economic ethics of the laity, we formulated the following expectations:

1. There is no single category describing the economic ethics of the modern Orthodox laity showing varying degrees of involvement in the life of the Church. This happens due to the fact that they employ:

1.1. different intra-Orthodox discourses offering their different vocabularies of motives for 'correct' Orthodox actions;

1.2. different discourses describing the motivation to action in the modern world ${ }^{8}$ outside of Orthodoxy; reception of these vocabularies of motives largely occurs beyond control of the carriers of the Orthodox tradition. ${ }^{9}$

2. At the same time we were able to formulate an alternative expectation: the economic ethics of the Orthodox laity is described by the category of humility.

Our assumption that the Orthodox ethics of humility shares an elective affinity with hierarchical systems of social organization [Zabaev 2009] requires attention to concrete manifestations of Orthodox actions. Moreover, it is necessary to take into account a typology of economic actions and methods of organizing economic systems. For doing that, after the phase of the project on motivations (stages 3, 4 and 5), we focused on elaborating the theory for gift giving (the family of theoretical codes, per [Glaser 1978]). For the empirical verification of additional expectations formulated following this theory, we conducted fieldwork in stages 5 and 7 in Arkhangelsk Region, Ryazan Region, and Chita Region.

The list of our main assumptions made for verification through field research, as well as the direction of how these assumptions evolved, are summarized in Table 2.

\section{Vocabulary of Motives. Humility}

The main thesis of this section can be formulated in the following way: since many actors operate today in the organizational field with different institutional logics, the vocabulary of motives among Orthodox actors is becoming enriched by categories from different sources.

The Russian Orthodox Church herself explicitly or implicitly also upholds one motive in her vocabulary humility - which is of Orthodox origin. This motive, we suggest, has the possibility for becoming a primary motive due to the fact that it is rooted in Orthodox doctrines and shares an elective affinity with the logic of organizing the life of the Church.

As a result of interviews with Orthodox participants on the parish life, we were able to compile a relatively lengthy vocabulary of motives for Orthodox economic activities / labor: Christian Self-Upbringing, Moral Attitudes in the Working Team, Serving the People, Productivity, Self-Development and Interest, Humility ${ }^{10}$.

8 In the sociology of religion, E. Pace demonstrated how 'communication' of religions and mutual enrichment with different categories takes place [Pace 2011]. The subject of cultural diffusion was discussed within very different fields. With regard to Russian theology, G. Florovskiy's concept of 'Western captivity' of Russian theology has received wide recognition [Florovskiy 1988]. See the criticism of this position in [Khondzinskiy 2012; Antonov 2006]. For the role of the category of 'development' in the textbooks of management, see [Boltanski, Chiapello 2011].

9 From the proportion of those who are sympathetic to Orthodoxy and those who are in contact with priests, as well as taking into account the amount of persons per one priest in modern Russia, it is clear that we cannot speak about any unified perception of texts issued by the Russian Orthodox Church.

10 The list of the identified motives is presented in another article (forthcoming). Here we just list them. 
The Study, "Economic Ethics of the Orthodox Laity." Theoretical Sampling

\begin{tabular}{|c|c|c|c|c|c|}
\hline & Phase & $\begin{array}{l}\text { Number of } \\
\text { respondents }\end{array}$ & $\begin{array}{l}\text { Dates of } \\
\text { fieldwork }\end{array}$ & Geography & Method \\
\hline \multicolumn{6}{|c|}{ Theme 1: "Orthodox Parish Community and Social Work of the Church" } \\
\hline 1 & 'Community' & 69 & $2012-2013$ & & Interview \\
\hline 2 & 'Social Work' 12 & 154 & 2013 & $\begin{array}{l}\text { Moscow Region, Irkutsk Region, } \\
\text { Khabarovsk Kray, Samara Region, Yaro- } \\
\text { slavl Region, Rostov Region, Altai Kray, } \\
\text { Tyumen Region, Krasnoyarsk Kray }\end{array}$ & Interview \\
\hline \multicolumn{6}{|c|}{ Theme 2: "Economic Ethics and Motivations of the Laity" } \\
\hline 3 & $\begin{array}{l}\text { 'Economic Eth- } \\
\text { ics. Educated in } \\
\text { Orthodoxy' }\end{array}$ & $\begin{array}{c}10 \text { (Mos- } \\
\text { cow) }\end{array}$ & 2013-2014 & Moscow, Minsk & Interview \\
\hline 4 & $\begin{array}{l}\text { Interview on } \\
\text { Economic Eth- } \\
\text { ics., 'Priests and } \\
\text { Parishioners' }\end{array}$ & 9 (priests) & & & \\
\hline $6^{13}$ & Summer of 2014 & $\begin{array}{l}\text { Moscow, } \\
\text { Moscow } \\
\text { Region, Ch- } \\
\text { ita Region }\end{array}$ & Interview & & \\
\hline 5 & $\begin{array}{l}\text { 'Tour of the } \\
\text { Deanery' }\end{array}$ & 18 & $\begin{array}{c}\text { Summer of } \\
2014\end{array}$ & Chita Region & $\begin{array}{l}\text { Par- } \\
\text { ticipant } \\
\text { observa- } \\
\text { tion }\end{array}$ \\
\hline 6 & Catholics & 12 & $\begin{array}{l}\text { Summer- } \\
\text { Autumn of } \\
2014\end{array}$ & Moscow & Interview \\
\hline \multicolumn{6}{|c|}{ Theme 3: "The Role of Debt and Elective Affinity between Ethics and Actions" } \\
\hline 7 & 'Debt' ${ }^{14}$ & 117 & $\begin{array}{l}\text { Spring- } \\
\text { Summer of } \\
2014\end{array}$ & $\begin{array}{c}\text { Moscow, Arkhangelsk Region (Arkhan- } \\
\text { gelsk, Kargopol); Ryazan Region (Ryazan, } \\
\text { Kasimov) }\end{array}$ & \\
\hline & $\begin{array}{c}\text { The total number } \\
\text { of interviews }\end{array}$ & 395 & & & \\
\hline
\end{tabular}

11 The complete name of the Project is "Social Work Organization on The Russian Orthodox Church Parishes in the First Half of XXI. Sociological Analysis". Research Grant: RNF 12-03-00565.

12 Field research at stages 3-6 was conducted as a part of the Project, "Economic Ethics of Orthodox Laity in Modern Russia. Sociological Analysis.” (Research grant of Russian Foundation for Humanities № 14-33-01031).

13 The complete name of the project is "Life in Debt. Social Meaning of Debt Practices in the Life of Communities in Russia." Research Grant of St. Tikhon's Orthodox University. 


\section{Motives from Orthodox Vocabulary. Struggle for the Interpretation of Humility (From Heroics to Obedience)}

The vocabulary of motives that surfaced in the narratives of the respondents is quite varied (in contrast to, for example, modern Russian Catholic vocabulary, which appears to be more consistent - partly due to the unified one-year catechization ${ }^{14}$ course obligatory for those wishing to join the Catholic Church ${ }^{15}$ ). We think that in the future one of these motives, namely the motive of humility, has great chances to become an 'official' legitimate motive of Orthodox economic activities. Our assumption is based on the following ideas:

1. It is the only motive which demonstrates a clear link with the vocabulary of Orthodox dogmas.

2. It shares an elective affinity with the currently existing organization of the Russian Orthodox Church.

Despite the fact that this motive currently has a dominant meaning in discourse (associated with obedience), we can still see that there are various reinterpretations of the concept 'humility' in the Orthodox setting of our day. The range of meanings of the term widely varies from obedience or submission on the one hand to heroic actions on the other hand. Below are some examples from interviews.

R.: I earned money by private taxi driving <...>. Such a Christian work ... you truly humble yourself... For example, some drunken company may get into the car or a drunken man who behaves in some disorderly way and may say anything that comes to his mind, may offend you, may hit on you anything you can imagine... For example, I could drive people to some event which was held in the vacation hotel where I once went for some corporate event way back when I was working as the head of a broadcasting station. I myself was in that role, lived in a luxurious suite - and now I come here as a simple cab driver. Well, it humbles one, it really does. The sign of that is that I had tears when I came there (female, age 34, Minsk).

R.: Was not Alexander Nevsky humble? And even Alexander Suvorov, was he not humble?! A person who goes to give his life, knowing that there is something higher even compared to his life - is that not humility? Humility can be defined as peace with God, always, even in the most extreme situations. When they beat you or when you beat someone, you have to be humble without losing peace with God, you need to do the will of God. If you are really defending people holding a gun in your hands, if you do not let a rapist, a scoundrel, a murderer go on with his crime-you can be a humble person. $<\ldots>$ Humility. The Lord is humble - when he expelled the merchants from the temple, was he not humble? Today humility is understood as a kind of lack of will and a passive submission to the external circumstances. I am treated badly, but I bear this. What for? You should not tolerate what cannot be tolerated 'for the sake of humility.' With love - please do, this is very difficult. But we step back before difficulties, forgetting that Christ is the victor. We step back before difficulties, pretending that we are falsely humble, we keep silent still boiling inside; there is no peace with God, or with the others, or with yourself. $<\ldots>$ This is not humility, this is a distortion of the Christian church life, complete distortion (Archpriest, age 65, Moscow).

\section{Humility and Types of Economic Systems}

Following the logic of 'elective affinity' proposed in The Protestant Ethic, we turn to the task of detecting a common element in some logic of motivation and in a particular type of economic system. At this point, our supposition is that in the first place we need to search for an elective affinity between three types of economic

14 Catechization is the course of teaching Catholic dogma, discipline and ethics.

15 From the interviews with Moscow Catholics, it can be concluded that the love to God and to people is the leading motive in their work life. For more detailed information see our forthcoming text on this issue. 
systems and the logic of humility. We think that only such a motive out of the entire vocabulary of motives among Orthodox actors (1) is rooted in the Orthodox doctrines ("is exclusive to Orthodoxy"), (1a) is present explicitly or implicitly in the main body of Orthodox literature, ${ }^{16}$ and (2) describes a model of action in terms of balance between goals and means, rather than dividing the goals into those pleasing God and those not pleasing God.

We suggest that the motivation of 'humility' will not appear to be in elective affinity with every type of economic life. The following examples demonstrate how the respondents working for companies in the free market, in hierarchical structures, or operating in the networks of mutual assistance, categorize their activities. In the following examples we focus on whether the category of humility surfaces in their narratives, and how it marks a specific type of economic organization.

\section{Humility and the Market}

1. Humility does not yield, when it is forcefully united with the market motivation and its legitimate range of goals. Entrepreneurs sometimes quit doing business.

R.: It was 1990. I did everything. I worked wherever they paid. Then by gigantic efforts I created my own business. Thus, shoving my conscience deep in my pockets, I decided start doing business, because, speaking somewhat pretentiously, without soiling your conscience, you cannot do this work... Because you have to do all sorts of dealings repugnant to human nature: with the police, with crooks. $<\ldots>$ Several years ago (a long time ago), I decided to become a priest, so I came here to study, and my business exists separately from me. Some other people do it. Well, for me to subsist, because I cannot be seriously engaged here and there at the same time.

\section{I.: Did you talk about it with the priests? Did you raise these problems with them?}

R.: Yes. But what can they tell me? Be patient, pray. If only they told me: here, this is a job for you! No. Nobody would say so.

\section{I.: Did you follow the recommendations they gave you?}

R.: And what would they know about the business? I have my own recommendations. Had I followed their recommendations, maybe I would have lost my business long ago. Theoretically, I know everything about business myself. I follow their recommendations concerning life (male, age 49, Moscow).

1a. In the case of necessity, a respondent's world may become divided into two realms: in one realm the Orthodox logic is allowed, while the logic of market success operates in the other realm. ${ }^{17}$ This often happens among 'successful' rich Orthodox, those Orthodox who became churched after they had become successful in business. ${ }^{18}$

The absolute ideal is as Christ said, "Whoever is greater among you, should be the servant to all." And He girded and began to wash the disciples'feet. Moreover, when Peter was troubled by this, the Lord told him, "If I do not wash your feet, you will have no part with Me." This is the ideal - when

16 See [Zabaev 2007].

17 It is very probable that such a division correlates with the description in [Nelson 1949].

18 Sometimes the logic, described by Gooren for the Pentecostals, is involved [Gooren 1999]. 
the power of the person, the potential of his personality, is aimed at serving his neighbor, which is based on service to God. I do not know to which extent these categories are close to the modern business... I can only say with regret that this is not implemented in my company (male, age 33, Moscow) [Pal'cheva 2005].

Humility, which is unanimously recognized as the most important virtue, cannot be considered a guiding principle in the working world. It is as if work becomes 'excluded' from the scope of this idea and may even displace humility, forming a separate, parallel world. The data shows that people who work in the market and consider themselves Orthodox separate humility and working processes in the companies which operate in the market.

\section{Humility and Hierarchy}

2. Humility makes it possible to form monolithic hierarchies by fostering a motivation which is easily embedded into patron-client relationships. ${ }^{19}$ It may be supposed that ethics of humility help the actors involved to avoid situations of potential conflicts, thus promoting the conservation of existing structures instead of change and reformation of those structures.

2a. However, humility in hierarchies and patron-client relationships may be expressed in other types of behavior, such as opportunism, time-serving, or parasitism, where the subordinate person, in accordance with the model of patron-client relations, begins to extract additional benefits from his position. ${ }^{20}$ Passivity is easily wrapped in humility.

Everything seems somehow mismatched; some elementary things are not complied with, that is, if the assignment is given with a deadline, no one cares at all if the deadline is not kept for months. At the same time everybody knows that no one will yell at them, and for some reason everyone takes advantage of that. That is, on the one hand, it is a very big plus that there is much more love in Orthodox structures, much more human attention, more relation to each other. But at the same time, instead of being grateful for that, instead of appreciating that, some kind of consumer attitude emerges. And a person thinks, well, they will not fire me anyway. It is not customary for the Orthodox to fire people, everybody has gotten used to the situation; everybody will be humbled; everybody will bear all my shortcomings. And everybody uses this. Of course, I am reducing everybody to the same level. But I see it in myself, that I behave just like that sometimes (female, age 33, Moscow).

Much was written about the humility of this type in the milieu of monks, monastic and married clergy, and seminary students, especially in respect to the Synodal period [Pomyalovskiy 1949; Rostislavov 1866]. Moreover, this type of humility can very easily be deduced from the monastic literature. In the situation after the period of forced secularization, in the absence of a sufficient number of those who bear the living tradition, many of those who sincerely wish to join the Orthodox Church, primarily focus on the literature of monastic origins. It was not without reason that the saying "angels are light for the monks; monks are light for the laity" is widespread in the Orthodox discourse. The majority of canonized saints were monks (and there are no lay people among the saints apart from holy soldiers and martyrs), and so on. The entire logic of the Orthodox discourse seems to push people to perceive things which happen in the world around them through a monastic lens. ${ }^{21}$

19 For the substantiation of this hypothesis as applied to Soviet socialism, see [Zabaev 2009]. See also [Popov 1987; Bek 1971].

20 See [Graeber 2015; Barsukova 2003, 2004].

21 In more detail, see [Zabaev 2012]. 


\section{Humility and Gift Giving}

3. Humility shares an elective affinity with gift giving, and being consistently implemented it leads to a number of positive effects, such as the growth of communities and social capital of people, which, in turn, positively affects changes in individual behavior of the believers (as an example in the economic realm, we can mention the deliverance from erratic bank loans).

As we remember, Marcel Mauss viewed the gift as a sum of three types of operations: to give, to receive a gift, and to give back. Analyzing the concept of Mauss, G. Yudin wrote,

Yet, Mauss, apparently, made a mistake in his main point, believing that the main anthropological transformation inherent in the market economy is the undermining of the third principle of gift exchange - "one needs to give in return more than what was received." In fact, modern utilitarianism strikes the most serious blow at the second principle — "it is necessary to receive a gift." Switching from the mode of gift exchange into the mode of market interaction indicates the refusal to accept the challenge of gift exchange. Instead, the desire to 'pay back' comes to the foreground, that is, the desire to reduce the content of interaction to the value of the subject of exchange, to evaluate it and immediately withdraw from the interaction by paying a price [Yudin 2015: 37-38].

It should be mentioned that the Orthodox actors themselves understand humility, among other things as elimination of pride (the absence of pride).

R: But always, always, you certainly want to solve your problems on your own. Maybe it's some lack of confidence in yourself, like what if... But it often does not in any way depend on whether you believe or not, but there is such a thing: well, I have to handle everything myself, I am a grown-up, I have to solve my problems with my own efforts. And at the same time, during these three years, the church, the parish have taught me that there is nothing shameful in saying, hey, guys, I have a problem, I would be very grateful if you help me solve it. $<\ldots><$ The parish $>$ heals pride. Why, why don't we want to ask for help? Because somebody told us, someone persuaded us, that we need to be absolutely successful, that everything always should be amazingly great, one hundred percent. But why does everything have to be always good? Sometimes something may go wrong, or for some reason something may not work out well for you, because no one is perfect (female, age 37, journalist, Ryazan).

The people who live this way, are not susceptible to succumbing to consumer debt, since in the case of need they would borrow from their friends, as the following quotes illustrate.

Now you can borrow, and now people would say, you'd better take it - well, knowing some situations, they say: you'd better take <money> from me, you'd better ask me, you will return it later. But... Here, I say, there is the thing that I'm a small, but proud birdy, yes (female, age 37, journalist, Ryazan).

Prior to joining the community, in the event of financial need the same respondent would not go to her friends, acquaintances, or family, but would resort to bank loan services.

R.: Once I <took> a bank loan, I was so crazy - we broke a thermometer at home, and mercury spilled. We have a very old parquet floor, and $<$ the mercury $>$ got inside, and I could not do anything to get it out it leaks again. And I simply went crazy, I went and took a loan, and bought a vacuum cleaner. But I took the loan in "Home Credit," so in the end this vacuum cleaner cost me probably 
seventy thousand <rubles> instead of the three thousand which I paid for it. That is, I paid, paid, paid, paid, paid, paid, and paid for, like, five years. Finally, I took another bank loan to close the first one (female, age 37, journalist, Ryazan).

Moreover, the most successful persons in community development, for example, reopening a church on a new territory, etc. are those who have mastered the mechanics of gift giving. Some emphasize the second operation (ask and accept a gift), but still start with the first stage - first giving the gift, as if (in addition) bestowing a set of reciprocal obligations on another person.

R.: I said: Semen Lvovich, here is some <holy> water the priest sent — will you take it? - I will. And I say: our roof is leaking. And right away, without a pause, I did not let him even breathe. That's $i t$, he will not refuse. One needs to somehow know how to ask. I don't know, you probably can't teach that to the young people. Yet one needs to learn. <... It needs to be done. But not for myself, for the church I will ask. For myself, it won't work out, I only may ask for Alexey Petrovich <church rector>, (female, age 70, retired, Kasimov).

Sometimes the gift giving cycle turns out to be one of the important resources of a priest who does not have any additional funds for restoring the church, or maintaining and developing the community. In doing this the priests are always in a difficult situation - a typical view of life and parishioners automatically emerges as a part of such an 'institutional logic.'

R.: I don't think there is something bad about it, but of course, nothing is written in the Lives <of saints $>$ about it. The priest, especially the rector, is always in such a situation, especially in a small town or village. Imagine, a woman comes to me, and I am talking to her, asking about her life, about her family; I need to devote to her some time. I know that if her husband is the driver of a Kamaz truck, this means that I have two opportunities to bring something <on the truck>. And so does every priest. Of course, after he takes the things, I will thank him, I will show him where the money or his efforts went, and will keep showing afterwards (male, age 45, clergyman (Archpriest), Samara Region).

On the other hand, 'normal' priests understand that it is wrong to allow this view to evolve. Both from the perspective of the Gospels (the relation to a person as an end and not as a means) and from the logic of the gift (the obligation of the reciprocal gift especially in a situation where there are no established reciprocal institutions like the Kula Ring), reciprocity emerges or is reinforced only when the party accepting the gift does not have a feeling that he is being used, or in other words, when the gift becomes sudden, unconditional, not expecting a payback [Yampol'skaya 2012]. A giver should behave in accordance with the oft-quoted verse in Matthew 6:3: "let not thy left hand know what thy right hand doeth", meaning not merely 'not expecting' anything in return (or planning), but even not 'knowing' that a favour was actually done.

\section{I.: This means, that there is always some kind of calculating intention?}

R.: Yes, but a very specific one. Probably life itself tells you what to do. How can I explain this? It is a calculation of Gospels. We have one priest - his parish is near the train shed, near the final station. The cars are always checked and washed there, and the sleeping homeless are always taken out of the cars. Then he did not think of doing anything with them, let alone construction work. He just really believed. The homeless were taken out; they wandered around the village; he would feed them in his parish, give them clothing, arrange documents for them, help as he could. They even were at his home all the time. His wife and his son got lice from them. But he did as he read in the Gospel - it told to give shelter and feed, and he fed. And then it turned out that there were many different skilled 
workers among them. They found an abandoned ZIL truck and fixed it; they fixed a MAZ truck with a crane, and they did different construction works. Now if somebody needs to start building, they go to his rectory. But I know him, he does not expect anything even now - he only lives like 'you need a bag of pasta for a week to feed the people, where can I get it?' This is his whole calculation - he simply reads the Gospels and does as it is written (male, 30 years, Ryazan region).

As can be seen from the previous example, the development of the gift giving skill does not mean an easy or parasitic life. Sometimes one needs to wait for the reciprocal gift for a very long time. And almost the only way to wait for it is to not expect it at all. The following example illustrates a situation where a young parish rector with no connections and no money is appointed to a destroyed village church, where there was no parish life for over seventy years. He arrives with his family, and his task is to restore the church life in the village.

R.: Only 10\% survived from the church; $90 \%$ was destroyed. I basically found ruins... Everything was cut off for seventy years. My ministry started $<\ldots>$ of 1990. Today I have twelve active parishes on the territory of the district; four old churches are being restored; two new churches are being built; I did the paperwork for getting the land for three churches, and in one village a building was given for a prayer house. Seven priests serve in the district (male, age 45, clergyman (Archpriest), Samara Region).

The rector pointed out that having no resources and being in an environment at best indifferent to the Church, he began simple work with the people. He started to establish a pattern of gift giving, building up a network of relationships and support with the only resource that he had - the network of emotional support:

R.: I tried to build relationships with the heads of the rural settlements, school principals, leaders of organizations. All birthdays, all names days, holidays, $<$ I would send $>$ greeting cards to all of them, and flowers to some of them, that is, I tried to visit them all, and to spend some time with all of them. $<\ldots>$ They also started to communicate, they too began to congratulate each other with the New Year, Christmas, Easter, began to send each other greeting cards. The church initiated this tradition. (male, age 45, clergyman (Archpriest), Samara Region).

And then he says that he started to receive gifts in response.

R.: It happened once that I was driving through the village, and there goes the former Party leader of the kolkhoz. I stop, get a book which I had with me, and say, "Happy Birthday, Petr Alexandrovich." He broke into tears. For so many years he worked in the kolkhoz as the Head, and until now no one has come and congratulated him. I honestly saw him by chance, and I remembered that it was his birthday, and for him it was a big deal. And later he started rebuilding the church in $<$ the village in the district $>$. He began to help, to do things $\langle\ldots\rangle$, began to inspire people that the church should be restored. In each village there is such a 'cell,' the core, the backbone. And then something starts to revive there (male, age 45, clergyman (Archpriest), Samara Region).

The pattern of gift giving was also launched by him in a different way. In addition, he began to organize all-village (not within-church) events in order to dismantle the stereotypes related to the Church and engage people in a common cause.

I began then to put up a Christmas tree on the territory; we have several thousand visitors over the Christmas week here in the area. In fact, all the Christmas festivities happen here on the area. Teachers, educators know perfectly well that we organize several charitable Christmas pageants on the territory of the church. Even the employees from village cultural centers would come and start circle 
dances and various other activities. $<\ldots><$ School students $>$ dance here, perform stage plays and other things. Whether it is freezing cold or not, a snow storm or not, they all gather here. In this way everything started. Then, we had a Christmas ski race. Not only from one school, school students come here from all over the district, we organize it here in the park. I borrow a kitchen truck from the Helicopter Academy <...> mobile kitchen trailer, buckwheat, tea, everything is free. A Christmas ski race was conducted in one more village; the Theophany ski race was organized in another village. They all wait; we come. We go to the Christmas ski race, and all rural settlements come (male, age 45, clergyman (Archpriest), Samara Region).

Obligations accompanying the gift gradually started to work. With a certain time lag, the rector received gifts in response:

R: I worked for seven years and did not see the results of my work, and began to despair. Only after the seventh year, I began to reap the results of my efforts and work. People's attitude began to change; the parishioners, the heads of villages, directors of enterprises. It was very difficult to break this stereotype. There were times when I would come to some production facility, speak about the problems, and receive an answer like, "I don't have money or building materials for priests. I have it only for people"... a couple of years later, this person asked forgiveness of me (male, age 45, clergyman (Archpriest), Samara Region).

As we can see from the above examples, there is a place for reciprocal gift giving practices in parish life. Moreover, we can also see that the actions of Orthodox actors manifest very different connotations of gift giving practices - literal calculating intent [Mauss 1996; Polanyi 1977], gift giving in such a way that the act of giving should be immediately forgotten [Derrida 1992], and building a networking of regifting [Sahlins 1972] with the simultaneous generation of social capital and informal authority, and parasitizing on the schemes of gift and humility in the hierarchy / clienteles [Graeber 2015]. We may assume that, at least on the level of the parish and its environment, it is precisely the gift exchanging practices, and not market or command-andcontrol practices, which are most influential.

\section{Conclusion}

The political scientist Maria Snegovaya is a scholar who probably expresses most clearly the liberal agenda in the modern scholarly community in relation to Orthodoxy. In the Vedomosti newspaper [Snegovaya 2014] she again raised the issue of paternalism as a part of the national unproductive culture, evidently contrasting it with liberalism as a productive culture [Snegovaya 2011]. These formulations follow a long line of similar statements. Neutral economic and political argumentation in dissertations are accompanied by passionate appeals by the same authors in the media to reform, by which they mean to reform according to a market viewpoint and the culture of pro $\neg$ ductive individualism. In this article we have tried to document a different point of view and demonstrate the potential impacts of a traditional (or unmodernized) religious viewpoint in the society of late modernity, opposing the neoclassical economics with anthropological and sociological approaches.

Is there anything in common among the image of Alexander Nevsky 22 which, according to an Orthodox priest, is humility, for "Greater love hath no man than this, that a man lay down his life for his friends" (Jn. 15: 13), an old woman asking for the church, a priest who organizes New Year's ski races or Christmas celebrations for several villages, a businessman giving money to the priest so he would buy an apartment for someone, a

22 Alexander Nevsky served as Prince of Novgorod, Grand Prince of Kiev and Grand Prince of Vladimir in XIII c. He rose to legendary status on account of his military victories over German and Swedish invaders while agreeing to pay tribute to the powerful Golden Horde. He was canonized as a saint of the Russian Orthodox Church by Metropolite Macarius in 1547 (Available at: https://en.wikipedia.org/wiki/Alexander_Nevsky (accessed 22 November 2015)). 
woman who got rid of 'erratic' bank loans with the help of voicing her needs in a parish, or a church which in three years taught its parishioner that there is nothing wrong with asking — is there anything in common among these things?

We believe there is. This is the pattern of gift giving as it is presented in the classic studies of Mauss [Mauss 1996] and Malinowski [Malinowski 1932], and was most vividly described by M. Sahlins. The essence of this system is that it is three-positioned [Sahlins 1972: 150], unlike the two-position exchange (that is characteristic of a hierarchical type of structures). In all the above examples, we may discern three positions: a woman asking from someone not for herself but for the church; Alexander Nevsky laying down his life for his friends; Christmas festivities which are organized not for the parishioners; breaking the link between a need and an erratic bank loan, ensured through the use of a third position, etc. A short definition of this principle is "to not ask for yourself."

The question of ethics in soteriological religions is a question of what is sacralized as a means towards salvation. Weber's Protestants sacralized success. We may assume that one of the principles of Orthodoxy is to sacralize a three-position pattern of gift giving, which can be potentially actualized from any of the positions. In other words, a humble person is a person who can give, accept a gift, and knows that he has to give a gift in response.

Our work attempts to point out aspects of Orthodoxy which are important for social and economic life. We attempted to show that the economic ethics of Russian Orthodoxy, which can be categorized as the ethics of humility, appears to share an elective affinity with the principle of economic integration known as reciprocity. This form of integration and this type of personal attitude work in the direction of reinforcing social solidarity. In the next step, as we have shown, this solidarity has important economic functions, for example, the deliverance of people from hysterical consumerism, in particular, from erratic bank loans, in Orthodox parishes (communities with high moral density) due to the operation of the networks of support ${ }^{23}$. Such a type of economy is often categorized as the 'informal economy' [Hart 2010] and is not counted in GDP. This does not mean that it is either useless or unproductive. The rate of informal economy varies from country to country and this rate is quite high in post-communist countries. We think these results should be taken into account when discussing the 'unproductivity' of the motivations in any religion, and the impact of these motives on a nation's economy and social activity.

\section{Acknowledgements}

The research referred to in this article was funded by a grant from the Russian Foundation for Humanities as a part of the project No. 14-33-01031; a grant RNF 12-03-00565 (the Project "Social Work Organization on The Russian Orthodox Church Parishes in the First Half of XXI. Sociological Analysis") and a grant of the St. Tikhon's Orthodox University (the Project "Life in Debt. Social Meaning of Debt Practices in the Life of Communities in Russia").

The authors would like to express their gratitude to Dr. A. Bruening (Radboud University Nijmegen), Dr. K. Stoeckl (University of Innsbruck), Prof. K. Hart (University of London), Prof. G. Yudin (HSE), Prof. N. Emelianov (St. Tikhon's Orthodox University), A. Belyanin (HSE), E. Berdysheva (HSE), Z. Kotelnikova (HSE),I. Pavlyutkin (HSE), E. Prutskova (St. Tikhon's Orthodox University) and P. Vrublevskaya (HSE), for their invaluable contribution and thoughtful commentaries on different versions of the paper. Some of the voiced suggestions will be addressed in the article to follow.

23 For the discussion about positive relationship between social capital and economic growth see, for example, [Putnam, Leonardi, Nanetti 1993; Whiteley 2000; Schneider, Plumper, Baumann 2000; Neira, Vazquez, Portela 2009]. 


\section{References}

Akerlof G. (1994) Rynok "limonov": neopredelennost' kachestva i rynochnyy mekhanizm [The Market for "Lemons": Quality Uncertainty and the Market Mechanism]. THESIS, vol. 5, pp. 91-104 (in Russian).

Antonov M. F. (2006) Monastyrskoe khozyaystvo [Monastic Economy]. Bol'shaya entsiklopediya russkogo naroda. Tom "Russkoe khozyaystvo" [Big Encyclopedia of Russian People. Vol. "Russian Economy"], Moscow: Institut russkoy tsivilizatsii (in Russian).

Albrow M. (1990) Max Weber's Construction of Social Theory, London: Macmillan Education.

Barsukova S. Y. (2004) Retsiproknye vzaimodeystviya. Sushhnost', funktsii, spetsifika [Reciprocal Interactions. Substance, Functions and Specifics]. Sotsiologicheskie issledovaniya, vol. 9, pp. $20-29$ (in Russian).

Bek A. A. (1971) Novoe naznachenie [The New Destiny], Frankfurt/Main: Posev (in Russian).

Boltanski L., Chiapello E. (2011) Novyy dukh kapitalizma [The New Spirit of Capitalism], Moscow: The New Literary Observer Publishing House (in Russian).

Chirkov V., Knorre B. K. (2015) Russian Orthodoxy and Human Motivation: The Categories of 'Sin', 'Humility', and 'Obedience' in the Context of Human Agency and Autonomy. Journal of Psychology and Christianity, vol. 34, no.1, pp. 26-39.

Derrida J. (1992) Given Time: I. Counterfeit Money, Chicago: University of Chicago Press.

DiMaggio P. J., Powell W. W. (2010) Novyy vzglyad na “zheleznuyu kletku”: institutsional'nyy izomorfizm i kollektivnaya ratsional'nost' $\mathrm{v}$ organizatsionnykh polyakh [The Iron Cage Revisited: Institutional Isomorphism and Collective Rationality in Organizational Fields]. Journal of Economic Sociology = Ekonomicheskaya sotsiologiya, vol. 11, no. 1, pp. 34-56. Available at: http://ecsoc.hse.ru/2010-11-1.html (accessed 22 November 2015) (in Russian).

Dubovka D. (2015) Trudniki v sovremennom monastyre RPC: taktiki prisvoeniya dukhovnykh blag [Trudniki in the Modern Monastery of the Russian Orthodox Church: Tactics of Spiritual Goods Assignment]. Izobretenie religii: desekulyarizatsiya v postsovetskom kontekste [Invention of Religion: Desecularization in the Post-soviet Context] (eds. S. Shtyrkov, A. Panchenko, J. Kormina), Saint Petersburg: Izdatelstvo Evropeyskogo universiteta v Sankt Peterburge, pp. 63-81 (in Russian).

Fleurbaey M. (2009) Beyond GDP: The Quest for a Measure of Social Welfare. Journal of Economic Literature, vol. 47, no. 4, pp. 1029-1075.

Florovskiy G. V. (1988) Puti russkogo bogosloviya [Ways of Russian Theology], Paris: YMCA-Press (in Russian).

Glaser B. G. (1978) Theoretical Sensitivity: Advances in the Methodology of Grounded Theory, Mill Valley, Calif: Sociology Press.

Gooren H. (1999) The Dynamics of LDS Growth in Guatemala, 1948-1998. Journal for the Scientific Study of Religion, vol. 38, no. 1, pp. 59-71. 
Gough I. (1994) Economic Institutions and the Satisfaction of Human Needs. Journal of Economic Issues, vol. 28 , no. 1 , pp. $25-66$.

Graeber D. (2015) Dolg. Pervye 5000 let istorii [Debt. The First 5000 Years], Moscow: Ad Marginem Press (in Russian).

Grondona M. A. (2000) Cultural Typology of Economic Development. Culture Matters. How Values Shape Human Progress (eds. L. E. Harrison, S. P. Huntington), New York: Basic Books, pp. 44-55.

Guiso L., Sapienza P., Zingales L. (2003) People’s Opium? Religion and Economic Attitudes. Journal of Monetary Economics, no 50, pp. 225-282.

Harrison L., Huntington S. (2000) Culture Matters: How Values Shape Human Progress, New York: Basic Books.

Hart K. (2010) Informal Economy. The Human Economy a Citizen's Guide (eds. K. Hart, J.-L. Laville, A. D. Cattani), Cambridge: Polity, pp. 142-154.

Hayek F. A. (2005) Doroga k rabstvu [The Road to Serfdom], Moscow: Novoe izdatel'stvo (in Russian).

Hobbes T. (2001) Leviafan, ili Materiya, forma i vlast'gosudarstva tserkovnogo i grazhdanskogo [Leviathan or The Matter, Forme and Power of a Common Wealth Ecclesiasticall and Civil]. Moscow: Mysl' (in Russian).

Hofstede G. (2002) Organizatsionnaya kul'tura. Upravlenie chelovecheskimi resursami [Organizational Culture. Management of Human Resources], Saint Petersburg: Piter (in Russian).

Howe R. H. (1978) Max Weber's Elective Affinities: Sociology within the Bounds of Pure Reason. American Journal of Sociology, vol. 84, no. 2, pp. 366-385.

Iannaccone L. R. (1990) Religious Practice: A Human Capital Approach. Journal for The Scientific Study of Religion, vol. 29, no 3, pp. 297-314.

Iannaccone L. R. (1998) Introduction to the Economics of Religion. Journal of Economic Literature, vol. 36, pp. 1465-1495.

Inglehart R., Welzel C. (2011) Razvitie i demokratiya: chto my znaem o modernizatsii [Development and Democracy: What do We Know about Modernization?], Moscow: Novoe izdatel'stvo (in Russian).

Khodzinskiy P. (2012) Ponyatie "obshhiny" v russkoy bogoslovskoy traditsii vtoroy poloviny XIX — nachala XX v [The Notion of 'Obshhiny' in Russian Theology Tradition of the Second Half of XIX - XX Centuries]. Vestnik pravoslavnogo Svyato-Tikhonovskogo gumanitarnogo universiteta. Seriya 1: Bogoslovie. Filosofiya, vol. 41, no. 3, pp. 38-46 (in Russian).

Khudyakova E. S., Pepelyaeva E. V. (2013) Metody lingvisticheskogo analiza tserkovno-prikhodskoy subkul'tury [Methods of Linguistic Analysis of Church-Parish Subculture]. Sotsio- i psikholingvisticheskie issledovaniya, vol. 1, pp. 25-32 (in Russian).

Kiselev O. (2014) Retsenziya na Zabaev I. V. Osnovnye kategorii hozyaystvennoy etiki sovremennogo russkogo pravoslaviya: Sotsiologicheskiy analiz. Moscow: Izd-vo PSTGU, 2012. [Book Review on Zabaev I. 
V. Main Categories of Economic Ethics of Modern Russian Orthodox Christianity. Sociological Analysis. Moscow: Izdatelstvo PSTGU, 2012]. Religiznavch narisi, no. 5 (in Russian).

Knorre B. K. (2014) Contemporary Russian Orthodoxy: From the Social Paradoxes to the Cultural Model. Culture Matters II. Focus on Russia (eds. L. E. Harrison, E. G. Yasin), New York: Lexington Books.

La Porta R., Lopez-de-Silanes F., Shleifer A., Vishny R. W. (1997) Trust in Large Organizations. American Economic Review, vol. 87, no. 2, pp. 333-338.

Lehrer E. L. (2004) Religion as a Determinant of Economic and Demographic Behavior in the United States. Population and Development Review, vol. 30, iss. 4, pp. 707-726.

Malinowski B. (1932) Argonauts of the Western Pacific. An Account on Native Enterprise and Adventure in the Archipelagoes of Melanesian New Guinea, London: George Routledge \& Sons; New York: E. P. Dutton \& $\mathrm{CO}$.

Mauss M. (1996) Ocherk o dare. Forma i osnovanie obmena v arkhaicheskikh obshhestvakh [An Essay on the Gift: The Form and Reason of Exchange in Archaic Societies]. Obshhestva. Obmen. Lichnost' [Communities. Exchange. Personality], Moscow: "Vostochnaya literatura" RAN, pp. 83-169 (in Russian).

Medvedeva K. (2015) The Landscape of a Religious Workspace: The Case of a Russian Christian Orthodox Sisterhood. Russian Sociological Review, vol. 14, no. 2, pp. 70-81.

Morse J. M. (2000) Determining Sample Size. Qualitative Health Research, vol. 10, no. 1, pp. 3-5.

Morse J. M. (2010) Sampling in Grounded Theory. The Sage Handbook of Grounded Theory (ed. A. Bryant, K. Charmaz), London: Sage, pp. 229-244.

Moucourant J., Plociniczak S. (2013) The Institution, the Economy and the Market: Karl Polanyi's Institutional Thought for Economists. Review of Political Economy, vol. 25, no. 3, pp. 512-531.

Münch P. (1993) The Thesis before Weber: An Archaeology. Weber's Protestant Ethic: Origins, Evidence, Contexts (eds. H. Lehmann, G. Roth), Cambridge: Cambridge University Press, pp. 51-71.

Neira I., Vazquez E., Portela M. (2009) An Empirical Analysis of Social Capital and Economic Growth in Europe (1980-2000). Social Indicators Research, vol. 92, iss. 1, pp. 111-129.

Nelson B. (1949) The Idea of Usury: From Tribal Brotherhood to Universal Otherhood, Princeton: Princeton University Press.

Ostrom E. (1990) Governing the Commons: The Evolution of Institutions for Collective Action, Cambridge: Cambridge University Press.

Pace E. (2011) Religion as Communication. International Review of Sociology - Revue Internationale de Sociologie, vol. 21, no 1, pp. 205-229.

Pal'cheva A. (2005) Gruzchshik, kotoryy ne lyubit podnimat' tyazhesti [A Loader Who Doesn't Like to Lift Weights]. Neskuchnyy sad (electronic journal), vol. 1, no 15. Available at: http://www.nsad.ru/articles/ gruzchik-kotoryj-ne-lyubit-podnimat-tyazhesti (accessed 15 December 2014) (in Russian). 
Polanyi K. (1977) Livelihood of Man (ed. H. W. Pearson), New York: Academic Press.

Pomyalovskiy N. G. (1949) Ocherki bursy [Essays of Bursa]. Leningrad: Lenizdat (in Russian).

Popov G. K. (1987) S tochki zreniya ekonomista (o romane Aleksandra Beka "Novoe prednaznachenie") [From the Point of Economist's View (About Alexander Bek's novel "New Destiny")]. Nauka $i$ zhizn' (electronic journal), vol. 4. Available at: http://www.nkj.ru/archive/925/24580/ (accessed 13 November 2014) (in Russian).

Putnam R. D., Leonardi R., Nanetti R. Y. (1993) Making Democracy Work: Civic Traditions in Modern Italy, Princeton: Princeton University Press.

Robertson D. H. (1933) Saving and Hoarding. The Economic Journal, vol. 43, no 172, pp. 399-413.

Rostislavov D. (1866) O pravoslavnom belom i chernom dukhovenstve v Rossii (tom I) [About White and Black Orthodox Clergy in Russia. Vol. 1], Moscow: Aleksandriya (in Russian).

Rostow W. W. (1960) The Stages of Economic Growth: A Non-Communist Manifesto. Cambridge: Cambridge University Press.

Rousselet K. (2013) L'autorité religieuse en contexte post-soviétique [The Authority of Religion in the PostSoviet Context]. Archives de sciences sociales des religions, vol. 162, no 2, pp. 15-36 (in French).

Sahlins M. (1972) Stone Age Economics, Chicago, New York: Aldine Atherton, Inc.

Samuelson P. A. (1964) Theoretical Notes on Trade Problems. The Review of Economics and Statistics, vol. 46, no 2, pp. 145-154.

Schneider G., Plumper T., Baumann S. (2000) Bringing Putnam to the European regions - On the Relevance of Social Capital for Economic Growth. European Urban and Regional Studies, vol. 7, iss. 4, pp. $307-317$.

Schwartz S. (2008) Kul'turnye tsennostnye orientatsii: priroda i sledstviya natsional'nykh razlichiy [Cultural Value Orientations: Nature and Implications of National Differences]. Psikhologiya. Zhurnal Vysshey shkoly ekonomiki, vol. 5, no 2, pp. 37-67 (in Russian).

Smith A., Nicholson J. S. (1887) An Inquiry Into the Nature and Causes of the Wealth of Nations, London: T. Nelson and Sons.

Snegovaya M. V. (2014) Pochemu u Ukrainy ne poluchilos'? Strana mezhdu revolyutsiey i reformami [Why Did Ukraine Fail? The Country between Revolution and Reformation]. Vedomosti. 25 December. Available at: http://www.vedomosti.ru/opinion/articles/2014/12/25/ukraina-bez-reform (accessed 27 December 2014) (in Russian).

Snegovaya M. V. (2011) Vliyanie konfessional'noy prinadlezhnosti na sotsial'no-ekonomicheskie predpochteniya i povedenie religioznykh respondentov [The Effect of Religious Affiliation on Socio-Economic Preferences and Behaviour of Religious Respondents]. PhD Thesis, Moscow. Electronic Version (in Russian). 
Strauss A., Corbin J. (2001) Osnovy kachestvennogo issledovaniya. Obosnovannaya teoriya. Protsedury $i$ tekhniki [Basics of Qualitative Research: Techniques and Procedures for Developing Grounded Theory], Moscow: URSS (in Russian).

Thompson G., Frances J., Levacic R, Mitchell J. (eds.) (1991). Markets, Hierarchies and Networks: The Coordination of Social Life, London: Sage.

Titaev K. (2013) Hozyaystvennaya etika kak zerkalo russkogo pravoslaviya: sotsiologiya religii cherez prizmu sotsiologii prava. Retsenziya na knigu Zabaev I. Osnovnye kategorii hozyaystvennoy etiki sovremennogo russkogo pravoslaviya: Sotsiologicheskiy analiz. Moscow: PSTGU [The Economic Ethics as the Mirror of the Russian Orthodox: Sociology of Religion through Sociology of Law. Book Review on Zabaev I. Main Categories of Economic Ethics of Modern Russian Orthodox Christianity. Sociological Analysis. Moscow: PSTGU]. Sotsiologicheskoe obozrenie, vol. 12, no 3, pp. 195-202 (in Russian).

Titkov A. (2012) Retsenziya. Zabaev I. V. (2012) Osnovnye kategorii hozyaystvennoy etiki sovremennogo russkogo pravoslaviya: sotsiologicheskiy analiz. Moscow: PSTGU. [Book Review on Zabaev I. V. Main Categories of Economic Ethics of Modern Russian Orthodox Christianity. Sociological Analysis. Moscow: PSTGU]. Sotsiologiya vlasti, no 8, pp. 167-176 (in Russian).

Triandis H. C. (2007) Kul'tura i sotsial'noe povedenie [Culture and Social Behavior], Moscow: Forum (in Russian).

Troeltsch E. (1912) Protestantism and Progress: A Historical Study of the Relation of Protestantism to the Modern World, London: Williams \& Norgate.

Van den Bergh J. C. J. M. (2009) The GDP Paradox. Journal of Economic Psychology, vol. 30, pp. 117-135.

Weber M. (1990) Protestantskaya etika i dukh kapitalizma [The Protestant Ethic and the Spirit of Capitalism]. Izbrannye proizvedeniya. T. 9 [Selected Works. Volume 9], Moscow: Progress, pp. 61-107 (in Russian).

Whiteley P. F. (2000) Economic Growth and Social Capital. Political Studies, vol. 48, iss. 3, pp. 443-466.

Wuthnow R. (2005) New Direction in the Study of Religion and Economic Life. The Handbook of Economic Sociology (eds. N. J. Smelser, R. Swedberg), Princeton: Princeton University Press, pp. 603626.

Yampol'skaya A. (2012) Derrida mezhdu Marselem Mossom i Avgustinom [Derrida between Marcel Moss and Augustin]. Russkiy zhurnal (electronic journal). 20 November. Available at: http://www.russ.ru (accessed 15 October 2014) (in Russian).

Yasin E. (2003) Modernizatsiya ekonomiki i sistema tsennostey [Modernization of Economics and System of Values], Moscow: HSE Publishing House (in Russian).

Yudin G. B. (2015) Moral'naya priroda dolga i formirovanie otvetstvennogo zaemshhika [The Moral Nature of Debt and Formation of Responsible Borrower]. Voprosy ekonomiki, vol. 3, pp. 28-45 (in Russian).

Zabaev I. (2007) Motivatsiya khozyaystvennoy deyatel'nosti v etike russkogo pravoslaviya [Motivation of Economic Activity in Russian Orthodox Ethics]. Monitoring obshhestvennogo mneniya. Ekonomicheskie i sotsial'nye peremeny, vol. 1, no 81, pp. 149-160 (in Russian). 
Zabaev I. (2009) Obraz rebenka u zhiteley rossiyskikh megapolisov. Po materialam biograficheskikh interv'yu s rossiyanami reproduktivnogo vozrasta [Child's Image of Russian Megapolis' Residents. Based on Interviews with Russians of Reproductive Age]. Inter, vol. 5, pp. 40-56 (in Russian).

Zabaev I. (2012) Osnovnye kategorii khozyaystvennoy etiki sovremennogo russkogo Pravoslaviya. Sotsiologicheskiy analiz [Main Categories of Economic Ethics of Modern Russian Orthodox Christianity. Sociological Analysis], Moscow: Izdatel'stvo PSTGU (in Russian)

Zabaev I. (2015) The Economic Ethics of Contemporary Russian Orthodox Christianity: A Weberian Perspective. Journal of Economic Sociology = Ekonomicheskaya sotsiologiya, vol. 16, no 4, pp. 148-168. Available at http://ecsoc.hse.ru/2015-16-4.html (accessed 22 November 2015).

Received: November 26, 2014.

Citation: Zabaev I., Zueva A., Koloshenko Y. Humility and The Gift: The Elective Affinity of Institutions and Ethics in Orthodox Parishes. Journal of Economic Sociology = Ekonomicheskaya sotsiologiya, vol. 16, no 5, pp. 118-139. Available at http://ecsoc.hse.ru/2015-16-4.html 


\section{NEW BOOKS}

\section{Elena Gudova}

\section{"All Power to the Imagination!": A Leftist Critique of Bureaucratic Violence, Technologies and Rationality}

Book Review: Graeber D. (2015) The Utopia of Rules: On Technology, Stupidity,

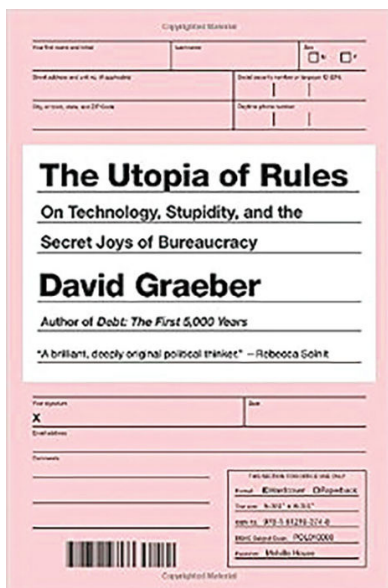
and the Secret Joys of Bureaucracy, New York: Melville House, 272 p.

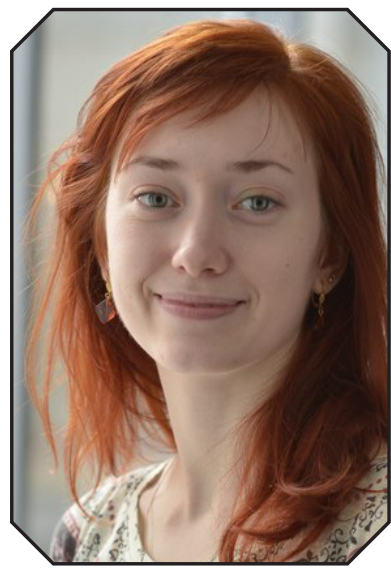

GUDOVA, Elena

Alekseevna - PhD

Student, Junior Research

Fellow, Laboratory for

Studies in Economic

Sociology; Lecturer, Department of Sociology, National Research University Higher School of Economics. Address: 20 Myasnitskaya str., Moscow, 101000, Russian Federation.

Email: egudova@hse.ru

\section{Abstract}

In the preface to The Utopia of Rules, David Graeber states that his book does not attempt to build up a new theoretical approach to bureaucracy but it is rather an essay collection with a focus on three bureaucratic features: violence, technology and rationality. However, the cornerstone of bureaucracy seems to rest on both unexpected and anticipated effects of creativity and imagination, whether related to the work of government officials and origins of sovereignty, force fields and contemporary science development, or superheroes and comic book history. Graeber not only illustrates why our life has been organized around filling out forms (p. 44), but gives it a wider scale through an anthropological understanding of bureaucratic practices and technologies. The interesting thing is that he never gives a precise definition of what bureaucracy really is and where we can find it, but in the disenchanted modernity and modern capitalist economy it seems to be omnipresent.

The book is divided into four thematic parts: the first is the structural violence and deliberate stupidity of bureaucratic institutions; the second questions scientific development and claims that we have moved from poetic to bureaucratic technologies; the third one is rationality and playfulness and their relation to human nature; and the last one (in an Appendix) considers the link between creativity and violence and the role of bureaucracy in it.

Keywords: bureaucracy; imagination; neoliberalism; capitalist markets; democracy; anarchism; violence; technology; rationality.

The Utopia of Rules by David Graeber is an essay collection with a focus on three bureaucratic features: violence, technology and rationality. However, Graeber's critique of bureaucratic practices always corresponds to human imagination and issues of rationality and creativity.

If we all know the irrationalities of bureaucracy and could possibly create any kind of social order we like, why would we still construct a reality where bureaucracy dominates? Or even this way: why do we need and like bureaucracy after all? Graeber gives this question a very broad answer. In the introduction "The Iron Law of Liberalism and the Era of Total Bureaucratization" he analyzes both 
historical and economic preconditions of bureaucratic order, and also makes a point that capitalist markets should not be opposed to bureaucratic government. In fact, capitalism requires a lot of red tape and is supported by structural forms of violence, which are produced by filling out forms.

In the "Dead Zones of the Imagination. An Essay on Structural Stupidity," Graeber continues the point stated in the introduction about violent bureaucratic technologies. This is a structural form of violence - a form of pervasive social inequality which is backed up by the threat of physical harm and implemented through thousands of rules and regulations. Violence simplifies communication and abandons any need of interpretative labor. Those at the very bottom of any social inequality are meant to figure out what is going on, while those at the top just let things slide. The inequalities supported by structural violence create dead zones of imagination - places where interpretative labor no longer works, communication is broken and we end up with paperwork relations.

In the section, "On Flying Cars and the Declaring Rate of Profit" the author states that we are deceived by all the great technological ideas of twentieth-century science fiction. Democratic progress requires market competition (and hence more forms and regulations), and poetic technologies of the scientific revolution sink in bureaucratic ones. For Graeber the main question is not whether we will ever have flying cars in a system, where scientists should already know what they are going to create when they apply for a grant (and no imagination allowed). The question is whether we are able to have flying cars and teleportation and all other science fiction things in a contemporary capitalistic system.

"The Utopia of Rules, or Why We Love Bureaucracy after All" is the last essay considering the rationality of bureaucracy. Graeber examines the philosophical origins of rationality in the Middle Ages and Romanticism and suggests that bureaucratic technologies sneaked into all spheres of human life (and imagination) through the ideas of public good provision, mixing calculative and substantive types of rationality and deprived humans of playfulness and creativeness. And this is important because bureaucracy is founded on a fear of free play, and the violence it creates allows humans to play only rule-bounded games - bureaucratic games, statesupporting games, market games.

The Appendix of the book, called "On Batman and the Problem of Constituent Power," shows us once again that bureaucracy creates forms of structural violence and enforces stupidity, but above all it is really boring. The rule-abandoning dark forces and violence are at least creative. No superheroes act, they just react, while real imagination is a feature of villains.

This review follows the structure of the book - each of the four parts is based on the chapter (except the Appendix, which is not reviewed separately). The structure of the book is not always easy to follow, because the material is very wide and detailed. However, the author's point is quite clear: structural violence and bureaucratic technologies challenge human imagination, and this is not because of the contradiction between state and market.

\section{"We Demand Rigidly Defined Areas of Doubt and Uncertainty!"1}

One can find a variety of origins for the Weberian ideal type bureaucracy: the Hegelian philosophy of right and views on the government; individual and public good [Shaw 1992; Sager, Rosser 2009]; Smith's and Marx's ideas of division of labor and specialization [Lewin, Minton 1986]; and the evolution of patrimonial authority [Gaydenko, Davydov 1991; Maslovskiy 1997]. Graeber gives multiple reasoning to it as well: political and economical implications (liberalism and market economy), evaluation and accounting technologies, and our psychological necessity to eliminate free play and creativity from rule-bounded game.

1 Douglas Adams, “The Hitchhiker's Guide to the Galaxy”. 
How did we end up in a society where every single movement and phenomenon is bounded by documents, accounting procedures and a crowd of civil servants? First of all, Graeber argues against the liberal's suggestion, that bureaucratization is a drag on capitalism. According to him, despite the fact that we mentally relate democracy with 'the market' and bureaucracy with 'the state', maintaining a free-market economy requires a thousand times more paperwork than a Louis XIV-style absolute monarchy (p. 9). One could state that bureaucracies are substitutes for impersonal market regulation mechanisms, which government uses to increase efficiency. From this point of view not a single profit-seeking enterprise is influenced by bureaucratization till the moment the government comes in, because it is against the nature of the firm [von Mises 1993]. But markets do not simply emerge, there always has to be something to do with the state.

If in the very beginning of the twentieth century the question was whether there is a way to run the government more like the market, the policy of corporatism simply adapted bureaucratic techniques to the private companies. Initially emerging in financial and corporate circles, estimation procedures and performance measuring gradually expanded to other spheres of life such as medicine, education, social policy, etc. This is what Graeber calls cultural transformation and the 'age of total bureaucratization'.

The age of total bureaucratization has its own iron law: any market reform introduced to reduce red tape has directly the opposite effect of maintaining the total number of regulations, paperwork and government employees (p. 9). This effect can be caused by simple implementation of legitimating practices and institutional myths with no regard for efficiency [Meyer, Rowan 1977], which often results in unreasonable credentialism. Such a capitalistic cult of documents, certificates and diplomas also corresponds to the idea of materiality: documents not only exist as instruments of bureaucratic organization, but rather constitute bureaucratic roles, knowledge, ideology, practices and sometimes even organizations themselves [Hull 2012a; Hull 2012b].

As far as the bureaucratization of everyday life means the imposition of impersonal rules and regulations, this type of adjustment can only work if backed up by the threat of force (p. 32). It can be substituted by the increasing meaning of social control and technologies, but at the end of the day it does not actually matter, because what really matters in that system, according to Graeber, is value (where he refers to Marx).

Value extraction in bureaucratic systems builds upon rationality (which refers to Weber) or, as we can call it 'technical efficiency', the way things are done. However, there is a huge difference between 'efficiency' and 'effectiveness': while the former is about input-output ratio, the latter is about an absolute level of either input acquisition or outcome attainment [Ostroff, Schmitt 1993]. We could relate this to the distinction between formal and substantive types of Weberian rationality, which can partially explain why much of bureaucrats' work is an evaluation of things, and why rational means may lead to irrational ends and red tape. This lack of reason is exactly the point where one might need the threat of force to back it up, at least as long as it is lucrative. Graeber states this in a more sarcastic way: "Whenever someone starts talking about the 'free market', it's a good idea to look around for the man with the gun" (p. 31).

This trend of financialization accompanied by growing technological advancement and social control has a lot in common with the classical issues of property, elites and power and, according to the author, is a self-sustaining web. Filling out forms in this case is not just an annoying obligation (and eventually it is not an anti-market invention), but a rather crucial element of the social order, which lies at the very heart of capitalist economy. And it is quite logical, Graeber claims, that we have the simultaneous development of force-employing institutions and financial institutions. As for bureaucracy, its function above the linkage between the two institutions is also in the implementation of violence, but in its structural form. 


\section{"Are You an Idiot? — No, Sir, I'm a Dreamer!”2}

Because violence for Graeber is not only a form of physical or mental harm, but can also take a structural form, he starts from a classical Lipsky street-level bureaucracy example: taking care of his mother's health involved so many senseless paperwork activities, that by the time he eventually resolved the problem with her medical insurance she passed away. In Graeber's terms it happened not just because of bottom-line effects and dysfunctions of bureaucratic systems, but because they are originally organized in such a way "as to guarantee that a significant proportion of actors will not be able to perform their tasks as expected" (p. 48).

The perfect order may never be attained, either because bureaucratic rules and regulations prescribe or proscribe an ideal sort of behavior with no effort put into its local interpretation [Hoag 2011] or because of a total ignorance of practical skills and acquired intelligence of indigenous people (metis) [Scott 1998]. In this way paperwork and bureaucratic procedures may complicate the existing social order, because they embed new rites of passage: the person can no longer become married, born, dead or mobilized for military service (at least with a proper social recognition) without a document-based ritual. Paperwork does not only prolong any liminal stage of these rituals, but is a liminal creature itself: they [bureaucratic procedures] are at once inanimate — lazy automatons, blindly serving larger powers — and animate — nefarious, self-interested obstructionists [Hoag 2011].

Graeber further highlights, that the senselessness of bureaucratic life and inability to rely on any reason or values directly leads us to the necessity of violence. And bureaucracy is dealing with a more subtle form of violence, a structural one, which implies "threats of physical force that lie behind everything from enforcing rules about where one is allowed to sit or stand or eat or drink in parks or other public places, to the threats or physical intimidations or attacks that underpin the enforcement of tacit gender norms" [Graeber 2012]. Structural violence is a form of pervasive social inequality which is backed up by the threat of physical harm (p. 57). Bureaucratic structures lack sense exactly in order to and because of this violent simplification, they are stupid not only as they produce stupid behavior, but rather as they manage social situations which are based on structural violence (p. 57).

Violence may be the only way of human communication which does not require real acts of communication: you hit a man over the head hard enough, and any interpretations or justifications become irrelevant (p. 67-68). Representatives of bureaucracy do not involve what the author calls 'interpretative labor' - part of the human communication based upon decoding an interlocutor's motives and perceptions. If normal communication requires imaginative identification (the actual knowledge of the social relations and their work) and sympathetic identification (sympathy or 'compassion fatigue'), communication based on structural violence creates lopsided structures of the imagination - an actual inequality in the ability and necessity of performing interpretative labor. Those on the bottom will always have to spend a great deal of energy trying to figure out what is going on, while those on the top of any social inequality let things slide. This is the very reason why bureaucracy will always produce absurdities (p. 81).

Bureaucracies are about simplification and schematization and, as Graeber puts it very strictly, they are confronting human imagination. The suggested 'reality' (the way bureaucracy constructs it) is not a welcoming place due to the fact that it systematically threatens us with violence. We imagine things we would like and bring them into being, according the social construction of reality, but why would we bring into being many disastrous events and phenomenon if we had an opportunity not to do so?

David Graeber claims that the contradiction between 'reality' and 'imaginary' often confuses two definitions of imagination: the 'transcendent notion of imagination' and 'the soul beyond any mere rationality' (p. 91-92).

2 “Scrubs" My Old Man TV series episode. 
The first one refers to what is simply beyond any reality and remains the same (one cannot change it because it does not actually exist), and the latter one is immanent, adapting and caught up in the projects of action. This latter type of imagination is responsible for interpretative labor (and communication respectively) and struggles with structural violence of real bureaucratic principles, senselessness and schematization. In that sense our inability to act creatively and use imagination to avoid violent outcomes is the very reason for inequality and alienation in capitalism. And this is the answer to the question stated above.

The only exception which seems logical here is revolution. If all so-called institutions of democracy and bureaucratic apparatus are intentionally alienating human imagination, 'revolutionary moments' disrupt unequal structures of imaginative identification and re-create everything around them (p. 100).

However, these movements demand a lot of work and power. A revolutionary should not only have the power to institutionally push forward ideas, but to escape the 'dead zones of imagination' - the spaces where interpretative labor no longer works due to the structural violence and its boredom and absurdity. These dead zones originate not from the lack of reflexivity, but merely from miscommunication - we can not ask the official representative for an explanation, we have to figure it out ourselves. And this is the point where bureaucracies can make anyone look stupid.

\section{"Since When can Weathermen Predict the Weather, Let Alone the Future?"3}

Since technological progress in the twentieth century has been so impetuous, we should have probably been using all those science fiction devices so far, but we are not. This conspicuous absence of flying cars is a secret shame of the new millennium, which makes us skeptical and uncertain both about past historical narratives of progress and future advancement. The only sphere we have actually developed is information technologies, or technologies of simulation. Graeber is very sure that beyond this layer of hyper-real images and surfaces lies a secret awareness that all our expectations turned out to be a lie.

Although our expectations about the future were not so unrealistic, we did not manage to come close to the picture of the world of 2015 as painted in the $1970 \mathrm{~s}^{4}$. David Graeber gives us two interconnected explanations, a political and a bureaucratic one. As he puts it, "there appears to have been a profound shift, beginning from the 1970s, from investment in technologies associated with possibilities of alternative futures to investment in technologies that furthered discipline and social control" (p. 120), "yet even those areas of science and technology that did receive massive funding have not seen the breakthroughs originally anticipated" (p. 130) (antithesis).

A political explanation is somehow obvious: there is a need to fulfill state interests, or the importance of military services and technologies, (as well as of grandiose projects such as the Human Genome Project in the USA or the whole Skolkovo project in contemporary Russia), plus the obligation to meet the demands of a neoliberal economy.

Bureaucratic explanation deals with resource allocation schemas and the growing influence of managerial logic. As progress was always presented as a problem that needed to be solved, the solution was 'democratic', i.e. 'bureaucratic': a creation of expert committees and panels to determine which inventions would be approved (p. 118). This development triggered a power inequality between the scientific community and the resourcestreaming institutions. In this situation nothing path-breaking can result, because the research is mostly driven

3 "Back to the Future" movie (1985).

4 There is still a place for pride and irony. Available at: http://www.vedomosti.ru/lifestyle/galleries/2015/10/21/613716-nazadbuduschee-kak-kompanii-povtoryayut-izobreteniya-legendarnogo-filma (accessed 29 November 2015). 
by political, administrative and marketing imperatives, and scientific labs and institutions are forced to adopt language, sensibilities and organizational forms that originated in the corporate world (p. 133).

This subject has been previously recognized by many scholars in organizational studies, higher education, economic sociology and other fields [DiMaggio, Powell 1991; Thornton, Ocasio 1999; Scott 2004; and etc.]. However, Graeber is far more precise in his vision of scientific development: the bureaucratic spirit suffuses every aspect of intellectual life and creativity, and intellectual competition looks more and more like market competition. This why we do not have time-travelling machines yet - how could there be a scientific breakthrough if scientists are involved in a huge paperwork competition where they need to persuade investors that they do already know what they are going to discover? (p. 135)

Similar to the first essay on violence, this part of the book on technology is about opposition between bureaucracy and imagination. Modern science has moved from poetic to bureaucratic technologies: if poetic technologies used rational and technical means to bring wild and impossible fantasies to life, bureaucratic technologies no longer encourage fantastic aims. Administrative imperatives have become not the means but the end of technological development (pp. 141-142).

For Graeber the ultimate question is not whether we are able to pull back and give all power to the imagination, but whether there is a possibility for innovation within the framework of contemporary corporate capitalism (p. 146). Our technologically sophisticated society is not doomed to exist on the basis of capitalism. Why? Because bureaucracies are actually not drags on capitalism but outcomes, and the pace of change cannot be held back forever by hostile bureaucratic obligations to fill out more and more forms.

\section{"Guys, Rules are Good! Rules Help Control the Fun!"'}

The third essay in the book is on rationality and value. Rational efficiency and value-neutrality are the very basics of any bureaucratic system, but they are not the only features of bureaucracy. Graeber gives 'our secret joy of bureaucracy' justification in multiple reasons and turns it in into four theses.

In his first statement Graeber observes the implication of bureaucratic technologies through the ideas of welfare state and public good provision. Thus, the origins of the German welfare state and public goods provision were a state's alternative to what might leftist parties and trade unions have offered (maybe by the terms of revolution). And this alternative combined the administrative structure and military (i.e. hierarchical) principles with fulfilling social demands. The first example of such a kind was the German post office.

Postal services have always been a strategic sphere of state operation and administration, which has two main sets of reasons: economic and non-economic. Economic reasons are usually considered a natural monopoly production technology and economy of scope [Priest 1975; Sidak, Spulber 1996], while non-economic reasons are providing universal postal service and security of the mail stream [Campbell Jr., Gharbi 1992; Richard 2000]. But we could also put here information and communication, and power of the state legitimation as well.

In his Imagined Communities, Anderson states that there were three institutions of governmental power which influenced the form, function, and mechanical reproduction of colonized zones: census, mapping and museum. These institutions "profoundly shaped the way in which colonial state imagined its dominion — the nature of the human beings is ruled, the geography of its dominion, and the legitimacy of its ancestry" [Anderson 2006: 168]. The formal apparatus of the census conjured up the delimiting territory where, for political purposes, they ended. By this sort of demographic triangulation, the Census filled in politically the formal topography of

5 "Friends" The One With The Kips TV series episode. 
the map. And the postal service provides an objectification: a zip code. This may seem naïve, but the Zone Improvement Plan (ZIP) coding system explicitly presented to the citizen the fact: no mailbox equals no rights.

The phenomenon of the German post office was wanted and needed, both at the top and at the bottom. Its magnificent efficiency, as author mentions it, was not only a modern Wonder of the World, but an organizational model for the Soviet Union, US Federal Government, private businesses and many other structures and institutions. The United States even created the term 'postalization' to express the mixture of nationalization processes and practices of bringing in postal principles of organization. But then something went wrong, demonized our whole perception of the postal service and linked it with all the sins and absurdities of government malfunctioning.

Graeber suggests that convincing the citizens that government does not really work was a political campaign (the neoliberal one) with the postal service as a state representative at the forefront. But it was not particularly necessary, because postal services as an outcome of military-based communication system operate on the basis of bureaucratic technologies, not poetic ones. Moreover, postal services were not about communication, they were actually against it — or at least they strictly framed communication ${ }^{6}$ (p. 163).

In his second statement the author proposes that the rational grounds of bureaucracy are far too pretentious. The efficiency and impersonality of bureaucratic principles and postalization mix up two understandings of rationality: means and ends (or calculative and substantive types of it). There are different philosophical traditions, which could be divided into branches of rationalism and empiricism. If it was for the ideas of David Hume and Francis Bacon to defeat Rene Descartes' ideas, we might now be living in a different world where rationality is only a way to assess the reality more or less as it is, not a value in itself. And from this point of view it could have been imagination, not rationality, that sets humans apart from animals and forms our lives (p. 171).

In medieval philosophy, rationality was a way to achieve union with the divine, and not surprisingly it described the Kingdom of Heaven as a giant cosmic administration (i.e. in Dante's Divine Comedy). Bureaucratic principles cultivated on this attitude to rationality never claim to be anything less than a grandiose cosmologic scheme (p. 173). So why would one want to change it, metaphysically speaking?

The era of Romanticism proposed another vision of rationality and gave more power to the soul and imagination. Interestingly, the invasion of social life with bureaucratic technologies was manifested in the vast development of fantasy literature. But the characters, plots and subjects become more and more alike, and this is not because of the classical fairytale morphology named by V. Propp. Bureaucratic principles sneaked into the imagination - which is the third statement.

Graeber highlights that in a fantasy world only evil people maintain systems of administration (p. 183). And what is more important, fantasy literature negates basic principles of bureaucracy, as he suggests in the following points:

1. The division between good and evil creates such absolute values that it is impossible to be value-free neutral.

2. There are different races and creatures with different qualities, which makes it impossible to be indifferent and provide equal treatment.

6 That explains why we do have perusal of correspondence and privacy of correspondence which are both performed by the state and military services. 
3. Legitimate power is usually based on pure charisma, legitimate rulers do not employ the structural form of violence to enforce the rules.

4. Fantasy is about storytelling and narration, while bureaucratic operations are mechanical.

5. Bureaucratic principles are transparent (or at least pretend to be); while in fantasy riddles and puzzles lie in the core of the story (pp. 184-185).

But this does not mean that bureaucracy is absent from Fantasyland. Unification and accounting principles (i.e. through a computer or tabletop RPG) allow us both to escape an oppressing bureaucratic reality and feel that still it is a better and safer world.

And here Graeber questions imagination as playfulness. We do not make a distinction between a game and a play. It is a crucial point, because a game is rule-governed action, while play is a pure expression of a creative energy. "Games, then, are a kind of utopia of rules" (p. 191-192). What does it have to do with bureaucracy? Actually a lot. In that sense bureaucracy is founded on a fear of play.

Why would that be? Along with administration and politics, sovereignty is a key feature of the state, and sovereignty is understood as a legitimate monopoly on violence. Creative and imaginative play is a freedom for itself and does not fear violence. Therefore it is a distant relative to sovereignty, something out of control, and out of system, and out of the state.

Playfulness and the freedom it generates are limited by social structures and institutions. Still, on the other hand, pure play-based and game-based worlds are only ideal types. And it is not as bad as it may seem, since we can always find a combination of playfulness in real world conditions. The question is whether we are able to win back our playfulness and imagination from filling out forms.

A contradiction between bureaucracy and imagination in Graeber's opinion is rooted very deeply in our social life and perceptions. Structural violence and omnipresent bureaucratic technologies challenge the natural playfulness and creativity of a person. And this is not the creativity honored by Hans Joas [e.g., Joas 1996], it is the liberating freedom of action, not only reaction. It leads to the fair question of whether there can be a creative form of peaceful existence in the society we have built, because only dark and violent forces seem to be able and willing to smash structures and offer something in its place. Superheroes lack imagination, while the villains are relentlessly creative (p. 211).

Certainly The Utopia of Rules is an intellectual and profound critique of the existing neoliberal capitalism and free-market economy. Graeber's book is not an intricate scientific book, and his arguments are not hard to follow, despite the fact that he never gives bureaucracy a definition. Perhaps it was his idea to give the phenomenon a multi-dimensional leftist critique with a whole lot of real life linkages. And this interpretation would be reasonable, since to put all the pieces together the reader needs to be imaginative.

\section{References}

Anderson B. (2006) Imagined Communities: Reflections on the Origin and Spread of Nationalism, London; New York: Verso.

Campbell Jr. L. I., Gharbi E. M. (1992) The Future of the Universal Postal Union. Crew M.A., Kleindorfer P.R. (eds). Regulation and the Evolving Nature of Postal and Delivery Services, Dordrecht, Netherlands: Kluwer Academic Publishers, pp. 7-44. 
DiMaggio P. J., Powell W. W. (1991) The Iron Cage Revisited: Institutional Isomorphism and Collective Rationality in Organizational Fields. Powell W. W., DiMaggio P. J. (eds). The New Institutionalism in Organizational Studies, Chicago; London: The University of Chicago Press, pp. 62-83.

Gaydenko P., Davydov J. (1991) Istoriya i ratsiolnal'nost': sotsiologiya M. Weber i veberovskiy renessans [History and Rationality: Sociology of Max Weber and Weberian Renaissance], Moscow: Politizdat (in Russian).

Graeber D. (2012) Dead Zones of the Imagination: On Violence, Bureaucracy, and Interpretive Labor. The 2006 Malinowski Memorial Lecture. HAU: Journal of Ethnographic Theory, vol. 2, no 2, pp. 105-128.

Hoag C. (2011) Assembling Partial Perspectives: Thoughts on the Anthropology of Bureaucracy. PoLAR: Political and Legal Anthropology Review, vol. 34, no 1, pp. 81-94.

Hull M. S. (2012a) Documents and Bureaucracy. Annual Review of Anthropology, vol. 41, pp. 251-267.

Hull M. S. (2012b) Government of Paper: The Materiality of Bureaucracy in Urban Pakistan, Berkeley, CA: University of California Press.

Joas H. (1996). The Creativity of Action, Chicago: University of Chicago Press.

Lewin A. Y., Minton J. W. (1986) Determining Organizational Effectiveness: Another Look, and an Agenda for Research. Management Science, vol. 32, no 5, pp. 514-538.

Maslovskiy M. (1997) Teoriya burokratii Maks Max Weber i sovremennaya politicheskaya sotsiologiya [Max Weber Theory of Bureaucracy and Modern Political Sociology], N. Novgorod: Izd-vo NNGU (in Russian)

Meyer J. W., Rowan B. (1977) Institutionalized Organizations: Formal Structure as Myth and Ceremony. American Journal of Sociology, vol. 83, no 2, pp. 340-363.

Ostroff C., Schmitt N. (1993) Configurations of Organizational Effectiveness and Efficiency. Academy of Management Journal, vol. 36, no 6, pp. 1345-1381.

Priest G. L. (1975) The History of the Postal Monopoly in the United States. Journal of Law and Economics, vol. 18, no 1, pp. 33-80.

Richard J. (2000) Recasting the Information Infrastructure for the Industrial Age. Chandler Jr. A. D., Cortada Jr. J. W. (eds). A Nation Transformed by Information: How Information Has Shaped the United States from Colonial Times to the Present, New York: Oxford University Press, pp. 55-106.

Sager F., Rosser C. (2009) Weber, Wilson, and Hegel: Theories of Modern Bureaucracy. Public Administration Review, vol. 69, no 6, pp. 1136-1147.

Scott J. C. (1998) Seeing Like a State: How Certain Schemes to Improve the Human Condition Have Failed, New Haven, Conn.: Yale University Press.

Scott R. W. (2004) Competing Logics in Health Care: Professional, State, and Managerial. Dobbin F. (ed.) The Sociology of the Economy, New York: Russell Sage Foundation, pp. 267-287. 
Shaw C. K. Y. (1992) Hegel's Theory of Modern Bureaucracy. American Political Science Review, vol. 86, no 2, pp. 381-389.

Sidak J. G., Spulber D. F. (1996) Protecting Competition from Postal Monopoly, Washington, D.C.: AEI Press.

Thornton P. H., Ocasio W. (1999) Institutional Logics and the Historical Contingency of Power in Organizations: Executive Succession in the Higher Education Publishing Industry, 1958-1990. American Journal of Sociology, vol. 105, no 3, pp. 801-843.

Von Mises L. (1993) Byurokratiya. Zaplanirovanniy khaos. Antikapitalisticheskaya mental'nost' [Bureaucracy. Planned Chaos. Anticapitalistic Mentality], Moscow: Delo, Catallaxy (in Russian).

Received: October 30, 2015.

Citation: Gudova E. (2015) “All Power to the Imagination!”: A Leftist Critique of Bureaucratic Violence, Technologies and Rationality. Book Review: Graeber D. (2015) The Utopia of Rules: On Technology, Stupidity, and the Secret Joys of Bureaucracy, New York: Melville House. Journal of Economic Sociology = Ekonomicheskaya sotsiologiya, vol. 16, no 5, pp. 140-149. Available at http://ecsoc.hse.ru/2015-16-5.html 


\title{
Marina Spirina
}

\section{Governance, Markets and Institutions: Russia and Germany Compared}

\author{
27 September - 10 October 2015, Institute for East European Studies, \\ Free University of Berlin, Berlin, Germany
}

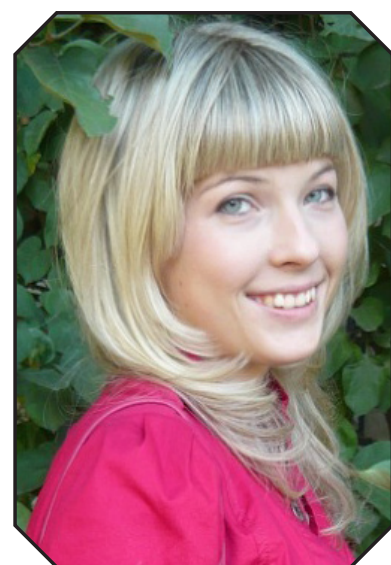

\section{SPIRINA, Marina}

Olegovna - MA student

in "Applied Methods

of Social Analysis of

Markets", Faculty of

Social Sciences; Junior

Research Fellow, Laboratory for Studies

in Economic Sociology,

National Research

University Higher School

of Economics. Address:

20 Myasnitskaya str.,

Moscow, 101000, Russian

Federation.

Email: mspirina@hse.ru

\begin{abstract}
The Summer School "Governance, Markets and Institutions: Russia and Germany Compared" was held from September 27 to October 10, 2015 under the coordination of the Institute for East European Studies, Free University of Berlin (Berlin) with the participation of Hertie School of Governance (Berlin), German Institute for Economic Research (Berlin), Higher School of Economics (Moscow) and European University at St. Petersburg (St. Petersburg). The Volkswagen Foundation (Volkswagen Stiftung) provided the Summer School with necessary financial support.
\end{abstract}

Around thirty doctoral students and postdoctoral scholars (both EU and non-EU) from a variety of disciplines including sociology, political science, economics, social anthropology, law, history and geography took part in this academic event. In addition, eight Russian MA students from social and political sciences were admitted as participants with special support from the Higher School of Economics.

The keynote speakers and lecturers from the Higher School of Economics (Moscow) were Alexander Chepurenko, Victoria Antonova, Fuad Aleskerov, Lilli DiPuppo, Andrei Melville, Yuval Weber, Andrei Yakovlev, Vladimir Zuev, Alexey Zakharov and Christopher Gerry. Nikita Lomagin presented his research on behalf of the European University at St. Petersburg (St. Petersburg). Among the participants from the Free University of Berlin (Berlin) were Katharina Bluhm, Carsten Schröder, Sabine Kropp, Tanja Börzel, Klaus Hoffmann-Holland, Philipp Engler, Klaus Segbers and Aron Buzogany. A number of scientists and researchers from other universities also took part in this academic event, including Klaus Desmet (Southern Methodist University, Texas), Volker Schneider (University of Konstanz, Konstanz), Nikolaus Wolf (Humboldt University, Berlin), Panu Poutvaara (Ludwig Maximilian University of Munich, Munich), David Woodruff (London School of Economics and Political Science, London).

Keywords: transition economies; German-Russian relationship; governance; financial system; informal entrepreneurship; inequality and cultural diversity; inclusive organizational culture; informal and formal institutions. 


\section{Introduction}

The Institute for East European Studies, Free University of Berlin hosted the Summer School "Governance, Markets and Institutions: Russia and Germany Compared” during September 27 - October 10, 2015. Theocharis Grigoriadis (Assistant Professor of Economics, Institute for East-European Studies, Free University of Berlin, Berlin) and Maria Polugodina (Research Fellow, Institute for East-European Studies, Free University of Berlin, Berlin) organized the summer school. Given the increasing interest in exploring causes of institutional and structural varieties of capitalism in advanced and transition economies, this Summer School aimed at fostering a network of scholars and experts to focus on the German-Russian comparison. Research topics included the peculiarities of German-Russian relations from both economic and socio-political points of view, governance, policy and financial system issues, informal entrepreneurship, the problem of inequality and cultural diversity, inclusive organizational culture, and so on. Researchers from a number of renowned German and Russian universities facilitated a discussion of innovative qualitative and quantitative research methods, including causal inference in the social sciences, field and lab experiments, and contributions to qualitative and mixed methods. The program comprised 80 academic hours of intensive work, combining different study formats (group work, workshops, lectures), meetings with experts and cultural events. During the last day of the Summer School, the participants presented their own research proposals developed in international multidisciplinary teams. Visits to Berlin research centers and institutions such as the Social Science Research Center Berlin, the German Institute for Economic Research, and the Hertie School of Governance illustrated comparative advantages of the Berlin-Brandenburg area for advanced social scientific inquiry. In addition, cultural events provided participants from abroad with a broader perspective on German history and society.

Summer School participants (doctoral students and postdoctoral scholars, but also some MA students) had the opportunity to improve their knowledge and skills in the sphere of institutional and structural changes, informality, and contemporary trends in modern economies through the lenses of social comparison research. A typical day of the summer school began with keynote presentations and lectures that were followed by open discussions and group work. The applied analysis, stimulating interactive academic environment and opportunity to enrich professional skills while working in interdisciplinary multilevel groups made the Summer School a worthwhile experience.

Due to the variety of topics that were explored during the Summer School, this review mentions only a few subjects at the thematic core of the program. First, this review mentions the question of German-Russian relations in the past, present and future from both economic and socio-political points of view. Second, it discusses the topics of governance, policy and financial systems. Third, special attention is paid to the different forms of informal entrepreneurship in Russia. Fourth, this review examines the sociological topics of inequality, diversity and culture. Finally, this review highlights the subject of inclusive organizational culture within the context of the professionalization of social workers, taking into consideration the interconnection between formal and informal institutional practices.

\section{German-Russian Relations: From the Past to the Present and towards Possible Future}

Since the Summer School was primarily focused on a comparison of Germany and Russia from the point of view of institutional and structural changes in the economy, the first part of the course was organized around socio-political relations of Germany and Russia as well as the ideological influence of the Western countries on Russia in a broad sense.

Approaching the problem of German-Russian relations from the historical point of view, T. Grigoriadis (Free University of Berlin) in his presentation "Russian Revolution and the Soft Budget Constraint" examined the role of the West in the economic choices made by Russia from 1905 to 1990 . He paid a special attention 
to the consequences that the specific structure of the financial system (centralized or decentralized) has on social and economic inequality. In his research, Grigoriadis tried to answer as well the question of how ideas of gradualism and shock therapy can explain economic reforms and how they contributed to the revolutions of 1905 and 1917 in Russia.

Based on an extensive review of the Russian and German economic literature from the 1960s to the 2000s, as well as historical evidence of the financial system's development, and industrialization in Russia during the second half of the nineteenth century linked with corresponding economic policies, Grigoriadis presented his own mathematical model explaining the association between the type of financial system and the rise of inequality in the first half of the twentieth century and the revolutions of 1905 and 1917.

At first, he introduced the idea that the choice between gradualism and shock therapy has a particular significance in the context of individual and aggregate uncertainty. Grigoriadis likewise observed that fiscal decentralization increases a government's opportunity cost for providing soft budget constraints, which often was the reason for Russia choosing a gradual policy instead of shock therapy. However, as Grigoriadis claimed, such a gradual economic choice had to be based on soft budget constraints and should be integrated into a highly centralized financial system. In addition to the importance of the policy of industrialization and securitization of liquidity undertaken by the Russian government, Grigoriadis emphasized the positive effect of the Russian-German relationship in the early nineteenth century and in particular of the German joint-stock credit banks in Russia. Grigoriadis concluded that active industrialization and a centralized financial system indeed may increase inequality and the propensity for revolution accompanied by elite repression. Grigoriadis suggested that his model could be seen as a starting point for a complex study of reform, industrialization and revolution.

K. Sebgers (Free University of Berlin) focused his research "Institutional and Ideological Foundations of an Alienation: German-Russian Relations in Crisis" on the main causes for the contemporary deterioration in relations between Germany and Russia in the context of broader Russian-Western interactions. Sebgers defined five different levels of this alienation: structural, institutional, governmental, societal and individual.

Considering the structural level of anarchy and polarities, Sebgers claimed that rule violations in Russia in 2008 and 2014 were not mere geopolitical actions but anti-Western reactions. As for the institutional level, Sebgers suggested that a general enlargement fatigue and the establishment of new defensive structures are the main challenges to be overcome by the European Union in the near future. According to Sebgers, the demonstrations and civil unrest in Ukraine in 2013-2014 were influenced by the double pressure of Western and Russian leadership. As for the governmental and societal levels, Segbers evaluated the weaknesses of the Russian state based on competing groups and interests and structural non-sustainable characteristics of the economy, but also on demography, health, education and infrastructure systems, as well as on illegal policies of the Russian government. Finally, on the individual level Segbers proposed to analyze the personal intentions of the political elites in closer relationship to the broader social, economic and political situation in the country.

Sebgers concluded by highlighting that in Western countries Russia is often pictured as a weak and insecure country which is not really the case. According to Segbers, one of the ways to overcome those prejudices is a gradual reconstruction and redevelopment of Russian-German relations including 're-engaging.'

\section{Governance and Financial Systems: Analysis of Policy Issues}

Political problems and governmental issues received a special attention during the Summer School. Such questions as the role of European Union in the global economic and political issues, financial system and its impact on global financial stability were elaborated by several lecturers. 
T. Börzel (Free University of Berlin) in her presentation "Good Governance and Bad Neighbours? The Limits of Transformative Power Europe" paid attention to the geopolitics of the European neighborhood and EU foreign policy as it varies by the economic, geographic, cultural and political proximity of different countries. Börzel presented a range of tools used by the EU in order to influence its neighbors such as soft incentives (e.g. simplified visa regulation), the persuasion of political dialogue, capacity building, and coercion through military and civilian missions. Börzel's main finding suggests that some of the EU's incentives are inconsistent and have little impact on external capacity-building for effective governance. According to Börzel, this situation leads to a more stabilizing policy instead of a more transformative one and this stabilizing policy includes encouraging political liberalization, consolidating hybrid regimes and supporting democracies.

D. Woodruff (London School of Economics and Political Science) explored the impact of the European financial system and its specific governance on global financial stability in his research on "Eurozone Governance and Global Financial Stability." By reminding the audience that financial exchanges are based on shared faith, Woodruff introduced the necessity of regulative mechanisms and institutions to promote, protect and repair this faith in order to allow financial prosperity and stability. Woodruff particularly highlighted the leading role of Germany and its specific variant of neo-liberalism ('ordo-liberalism'1) which creates conditions for the market economy and uses market panic as a major tool of influence (since market interest rates can play a role in pushing governments towards reforms and vice-versa).

P. Engler (Free University of Berlin) also focused his presentation, "Fiscal Devaluation in the Monetary Union", on the European Union's financial stability but within the specific scope of fiscal devaluation. His research examines the real effective exchange rate and its impact on competitiveness and the ratio exports/ imports. This topic was highlighted by the massive trade deficits within the Eurozone and the consequences of the debt crisis over the whole Union's spending. Engler explained how the real exchange rate could be reduced by fiscal rather than monetary instruments, such as the reduction of social contribution rate and the increase of the value added tax. Finally, Engler pointed out the fact that exports have limited effect, but the nominal wage rigidity still remains the very best element for effectiveness.

\section{Informal Entrepreneurship in Russia: Forms, Reasons and Types}

The question of informal entrepreneurial activity under transition recently has attracted attention from Russian and German social scientists. A. Chepurenko (Higher School of Economics) in his research "Informal Entrepreneurship under Transition: Forms, Reasons and Types" discussed the subject of informal entrepreneurial activity in the context of economic and political transition in Russia.

Citing extensive literature on embedded informal entrepreneurship (modernization, structuralist, neo-liberal and post-structuralist perspectives), Chepurenko raised the question of multiple definitions of informal entrepreneurial activity, often linked with the informal economy, as well as the problem of the considerable variety of forms and practices covered by this general term. Chepurenko highlighted some common characteristics within informal entrepreneurship such as off-the-book transactions ${ }^{2}$ with providers and customers, the absence of legal written contracts with employees, and informal forms of financing. Speaking about specifics of entrepreneurship under transition in Russia, Chepurenko made the difference between productive, unproductive, and destructive entrepreneurship. Importantly, in environments with 'free access order' there are more opportunities for productive entrepreneurship, than in environments with 'limited access order.' 3 Chepurenko

1 Ordoliberalism is the German variant of social liberalism that emphasizes the need for the state to ensure that the free market produces results close to its theoretical potential [Ptak 2009: 124-125].

2 "Off-the-book" is a payment or receipt of money for which no official record is kept.

3 "Limited access orders solve the problem of containing violence by political manipulation of the economic system to generate rents by limiting entry to provide social stability and order", while "open access orders sustain social order through political and economic competition rather than rent-creation" [North, Wallis, Weingast 2006: 4]. 
proposed his own typology of entrepreneurship in fragile environments by motivation and level of informality and distinguished the following types: 'Stars', 'Cynics', 'Fools' and 'Marginals' (See Fig. 1).

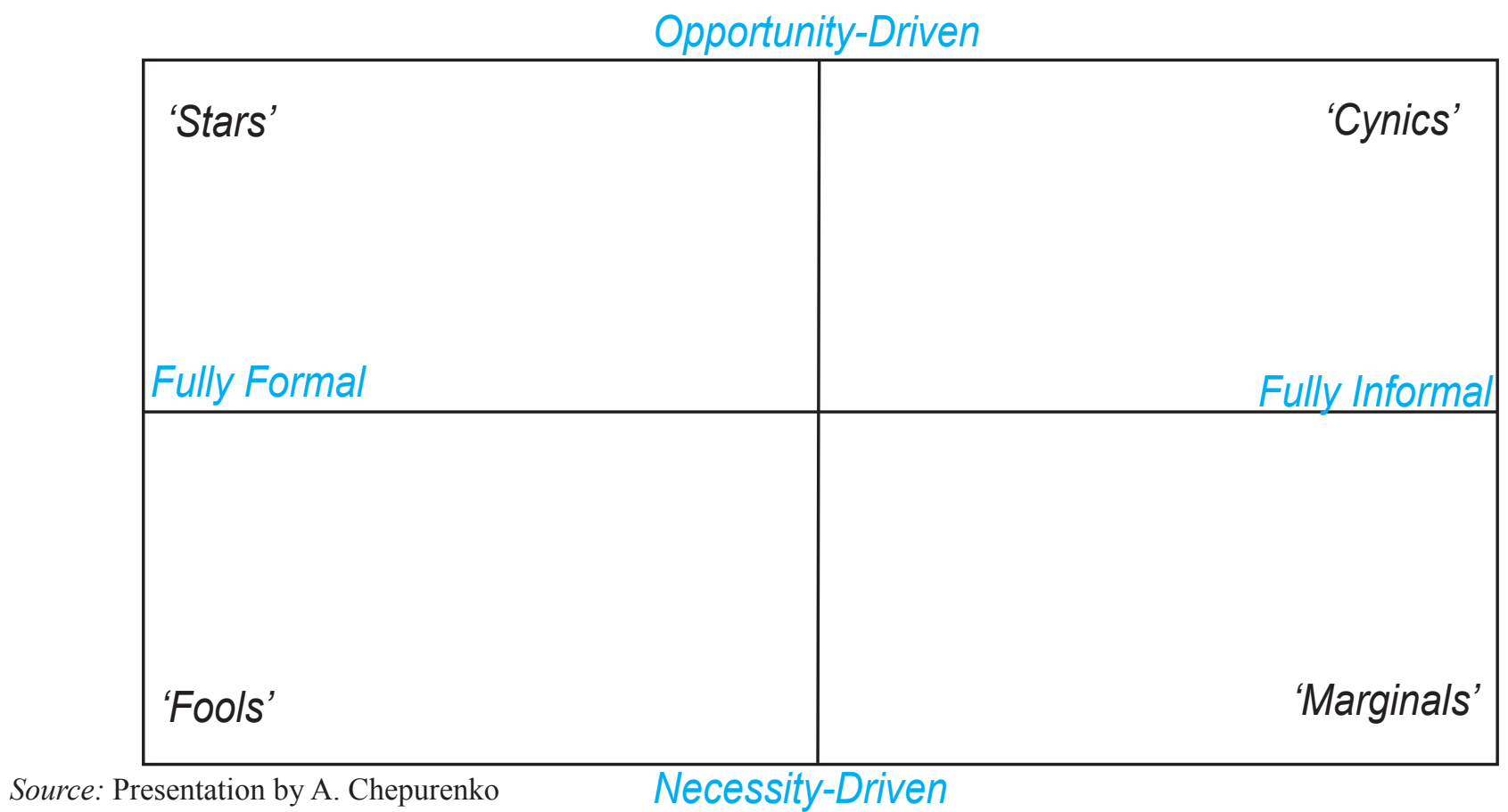

Fig. 1. Typology of Entrepreneurship in Fragile Environments by Motivation and Level of Informality

In the final part of his presentation, Chepurenko paid attention to several challenging questions concerning informal entrepreneurship. Should informal entrepreneurial activity be treated as a danger or as an institutional trap under a fragile economic environment? Which are the most appropriate research strategies to cope with informal entrepreneurship in transitional environments? Which concepts and paradigms should be used to explain the nature and sustainability of informal entrepreneurial activity in Russia and similar economies and societies? According to Chepurenko, informality is considered to be an institutional trap for most entrepreneurs under 'limited access order' where there is predominantly unproductive entrepreneurship. For this reason, we need a different approach from the state to different forms of informal entrepreneurship.

\section{Inequality, Diversity and Culture}

A number of researchers focused their work on inequality, diversity, and cultural issues within the European context.

K. Desmet (Southern Methodist University) in his work "Culture, Ethnicity and Diversity" addressed the problems of ethnic cleavages associated with deep differences in preferences, norms, values and attitudes within a changing society. Looking for a link between ethnicity and culture, Desmet underlined the assumption according to which people usually agree within groups and disagree across groups. According to Desmet, this topic is becoming extremely relevant in the context of massive migration, the politics of multiculturalism, the rise of inequality and the overall breakdown of social consensus.

Using individual-level survey data to explore the relations between ethnolinguistic identity and culture (World Values Survey, 1981-2008, 74 countries $^{4}$ ) Desmet made a clear distinction between ethnic diversity and cul-

4 The World Values Survey (WVS) is a global research project that explores people's values and beliefs, how they change over time and what social and political impact they have. It is carried out by a worldwide network of social scientists who, since 1981, have conducted representative national surveys in almost 100 countries. 
tural diversity, pointing out that culture is the main vector of traits reflecting individual values and norms. His research aimed at making clearer the determinacy of identity over culture, taking into account regions. Besides, as Desmet noted, ethnic fractionalization cannot be taken as a proxy for cultural diversity, making a reference to theoretical debates between constructivism and primordialism.

C. Schröder (Free University of Berlin) in his turn presented his research on "European-Wide Inequality in Times of the Financial Crisis." Examining the question of how disparities in material living standards in Europe have changed since the Great Recession, Schroder used cross-country micro-level data from EU official statistics on income and living conditions from 2005 to 2012. Schröder claims that the tendency to consider the EU as a single country while applying a pooled distribution of material living ignores the important gaps between countries on the welfare dimension. According to Schröder, the recent financial and economic crisis in Europe raises concerns about socioeconomic disparities in the EU and especially in its common currency area. Although the EU claims to be working towards convergence and social cohesion among its member states, in public perception, the countries of the EU are growing further apart.

\section{Inclusive Organizational Culture of Social Services in Russia: Formal Rules vs. Informal Practices}

V. Antonova (Higher School of Economics) presented her research "Inclusive Organizational Culture of Social Services in Russia: Formal Rules vs. Informal Practices" on inclusive organizational culture in the context of Russian social services with a special accent on the interconnection between formal and informal institutional practices. Antonova focused on the gap between wide-spread formal regulations and common informal practices and questioned the respective roles of both operative systems in society. The study was based on extensive qualitative data: a case study of two social service organizations in a region in Povolzhye ${ }^{5}$ and semi-structured interviews with Russian experts in the field of social work in the cities of Moscow, Saratov, Arkhangelsk, Tomsk and Ekaterinburg.

Antonova pointed out the fact that informal rules of the social work occupation are frequently derived from formal norms and these informal rules produce informal practices which might sometimes be contrary to the formal perceptions of the social work as an occupation.

Antonova paid special attention to the fact that the legitimization of informal practices in social work is being currently redefined: in order to be legitimate an informal practice has to be effective in terms of helping to solve problems and to meet the needs of the client. However, in many cases in order to become legitimate and effective, an informal practice ought to be developed and implemented by a social worker with a high level of innovative, critical thinking and courage, which, Antonova argues, is not expected in the public stereotype of this type of worker. In Antonova's opinion, informal practices are being institutionalized and becoming formal rules and norms in social work. Case study findings and results of interviews with social work specialists in five Russian regions suggested that some social service organizations in Russia are taking important steps towards developing an inclusive culture of their services, but these are being taken primarily at the micro-level of social policy.

Antonova concluded that the institutional and legal framework in Russia does not provide public social service organizations with coherent policies and legislation. In order to formalize their practices and programs and develop them further, local social service organizations require macro-policy developments which support the establishment of an inclusive culture in all public services.

5 Povolzhye (Volga Region) is a historical region in Russia that encompasses territories adjacent to the flow of the Volga River. 
Certainly the Summer School "Governance, Markets and Institutions: Russia and Germany Compared" was very fruitful for its participants in terms of expanding their knowledge about essential matters of governance, markets, formal and informal institutions from theoretical, methodological and empirical points of view. Furthermore, this academic event may also be considered as an important step towards the further cooperation between the Free University of Berlin and the Higher School of Economics.

The Summer School fostered contacts and stimulated exchanges between young scholars from Russia, Germany, and other countries, as well as introduced some possibilities for postgraduate study to a new generation of highly qualified young researchers from around the world. Everyone present considered participation in this academic event to be an important step for the future development of their academic careers.

\section{References}

North D., Wallis J., Weingast B. (2009) Violence and Social Orders: A Conceptual Framework for Interpreting Recorded Human History, Cambridge; New York: Cambridge University Press.

Ptak R. (2009) Neoliberalism in Germany: Revisiting the Ordoliberal Foundations of the Social Market Economy. Mirowski P.; Dieter P. The Road from Mont Pèlerin: The Making of the Neoliberal Thought Collective, Cambridge, MA.: Harvard University Press, pp. 98-138.

Received: November 11, 2015.

Citation: Spirina M. (2015) Governance, Markets and Institutions: Russia and Germany Compared, 27 September - 10 October 2015, Institute for East European Studies, Free University of Berlin, Germany. Journal of Economic Sociology = Ekonomicheskaya sotsiologiya, vol. 16, no 5, pp. 150-156. Available at http://ecsoc. hse.ru/2015-16-5.html 
Экономическая

социология

T. 16. № 5.

Ноябрь 2015

Электронный журнал www.ecsoc.msses.ru

www.ecsoc.hse.ru

ISSN 1726-3247

\section{Адрес редакции}

101000, Россия,

г. Москва,

ул. Мясницкая, д. 20, комн. 406 тел.: (495) 628-48-86 email: ecsoc@hse.ru

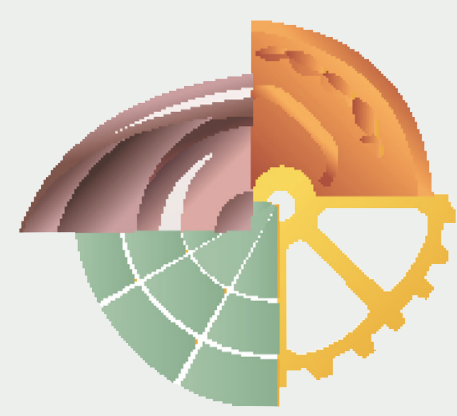

\section{Journal of}

Economic Sociology

Vol. 16. No 5.

November 2015

Electronic journal www.ecsoc.msses.ru www.ecsoc.hse.ru

ISSN 1726-3247

\section{Contacts}

20 Myasnitskaya street, room 406

101000 Moscow,

Russian Federation phone: +7 (495) 628-48-86

email: ecsoc@hse.ru

\section{Доступ к журналу}

- Доступ ко всем номерам журнала — постоянный, свободный и бесплатный.

- Каждый номер содержится в едином файле (10-12 п. л. в PDF).

- Если хотите, чтобы Вас оповещали о выходе очередного номера, пожалуйста, заполните форму подписки: https:/www.hse.ru/expresspolls/ poll/23725626.html.

\section{Open access policy}

- All issues of the Journal of Economic Sociology are always open and free access

- Each entire issue is downloadable as a single PDF file

- If you wish to receive notification when new issues are published, please fill out the following form: https://www.hse.ru/expresspolls/poll/23725626.html 